\title{
The Continuum of Deference: Supreme Court Treatment of Agency Statutory Interpretations from Chevron to Hamdan
}

\author{
WILliAM N. EsKRIDGE, JR* \& LAUREN E. BAER** \\ TABLE OF CONTENTS
}

INTRODUCTION $\ldots \ldots \ldots \ldots \ldots \ldots \ldots \ldots \ldots \ldots \ldots \ldots \ldots \ldots$

I. Methodology . . . . . . . . . . . . . . . . . . . . . . 1093

II. Empirical Findings: The Supreme CourT's ContinuUim of DefERENCE REgImes, Its APPLICATION OF ThOSE Regimes, AND Regulartities In Agency Win Rates . . . . . . . . . . . . . . . . . 1097

A. THE SUPREME COURT'S CONTINUUM OF DEFERENCE REGIMES . . . . 1098

1. Curtiss-Wright Super-Deference in Foreign Affairs/National Security $\ldots \ldots \ldots \ldots \ldots \ldots$

2. Seminole Rock Strong Deference for Agency Interpretation of Its Own Regulations . . . . . . . . .

3. Beth Israel Deference for Agency Elaborations of Statutory Schemes . . . . . . . . . . . . . . 1106

4. Skidmore Deference for Expert Agency Judgments . . . . 1109

5. Consultative Deference for Agency Inputs Where the Court Does Not Announce a Deference Regime . . . . . .

\footnotetext{
* John A. Garver Professor of Jurisprudence, Yale Law School. @ 2008, William N. Eskridge, Jr.

** Yale Law School, J.D. 2007; Law Clerk to the Honorable Robert D. Sack, United States Court of Appeals for the Second Circuit. (C) 2008, Lauren E. Baer.

.We presented an earlier draft of this Article as the Thomas Ryan Lecture at Georgetown University Law Center on November 4, 2007. We appreciate questions and comments we received at that Lecture and the dinner afterwards. We also received helpful comments from participants at Statutory Interpretation Colloquia at the Columbia, Georgetown, Fordham, University of North Carolina, and Yale Law Schools. For specific comments, we are grateful to John Donohue and Oona Hathaway, as well as to Alex Aleinikoff, Ian Ayres, Logan Beirne, Stuart Benjamin, Curtis Bradley, Madhu Chugh, Jon Donenberg, John Donohue, Chai Feldblum, Michael Gerhardt, Larry Gostin, Michael Graetz, Kent Greenawalt, Mitu Gulati, Don Hornstein, Avery Katz, Rebecca Kelly, Richard Lazarus, Marin Levy, Tom Merrill, Henry Monaghan, Vicki Schultz, Peter Strauss, Hanah Volokh, Sasha Volokh, and Mark Weisberg. We are particularly grateful to Professors James Brudney and Corey Ditslear for sharing with us the methodology employed in their empirical study of the Supreme Court's usage of canons of construction, and to Professor David Super for detailed comments on our methodology.
} 
6. Anti-Deference . . . . . . . . . . . . . . . 1115

7. No Deference Regime Invoked $\ldots \ldots \ldots \ldots \ldots \ldots 1117$

B. CHEVRON AS APPLIED (OR NOT) BY THE COURT $\ldots \ldots \ldots \ldots \ldots 1120$

1. Chevron and Agency Interpretations Pursuant to Congressionally Delegated Lawmaking Authority .... 1123

2. Chevron and Agency Interpretations Involving Jurisdictional and "Fundamental Policy" Issues . . . . . 1130

3. Chevron and Interpretive Methodology: The Use of Legislative History . . . . . . . . . . . . . 1135

C. PREDICTING SUPREME COURT BEHAVIOR $\ldots \ldots \ldots \ldots \ldots \ldots .1136$

1. Predicting Deference Regime Invoked . . . . . . . 1136

2. Predicting Agency Win Rates ............. 1141

a. Influence of Deference Regime . . . . . . . . 1142

b. Influence of Subject Matter .............. 1144

c. Influence of Open Process ............... 1147

d. Agency Consistency over Time ........... 1148

e. Statutory Plain Meaning ............... 1151

f. Ideological Voting . ............... 1153

III. Normative Issues: What Should Be the Supreme Court's APPROACH to AgENCY INTERPRETATIONS OF FEDERAL StatuTES? . . 1156

A. FORMALIST ANALYSIS: CONSTTITUTIONAL AND STATUTORY AUTHORITY RELEVANT TO AGENCY DEFERENCE . . . . . . . . . 1159

B. FUNCTIONAL ANALYSIS: AGENCY DEFERENCE AND THE RULE OF LAW, DEMOCRACY, AND INSTITUTIONAL COMPETENCE . . . . 1168

1. The Functioning of a National Rule of Law . . . . . . 1169

2. Comparative Institutional Competence ......... 1171

3. Legitimacy ..................... 1175

C. PUTTING IT ALL TOGETHER: WHAT SHOULD THE COURT'S DEFERENCE REGIME LOOK LIKE? . . . . . . . . . . . . . . 1179

1. Precepts That Ought To Guide the Court's Deference Jurisprudence . . . . . . . . . . . . . . . 1180

2. Simplify and Clarify the Deference Continuum ...... 1183 
3. New Procedural and Structural Suggestions That Might Facilitate Court-Agency Cooperation ............

CONCLUSION: RETHINKING STATUTORY INTERPRETATION IN THE MODERN AdMinistrative State . . . . . . . . . . . . . . . . . . . 1196

APPENDIX - CODEBOOK ........................ 1203

\section{INTRODUCTION}

The much-toasted "Chevron Revolution" began with a bubble. The Clean Air Act Amendments of 1977 capped pollution-emissions levels at "major stationary sources." Representing an Arizona smelting company, the tony Washington, D.C., law firm Shea \& Gardner persuaded the EPA that an entire cluster of buildings within an industrial plant should count as a single stationary source; this "bubble concept" would allow firms flexibility to offset increased emissions from one building by reducing them elsewhere within the single plant. ${ }^{2}$ The D.C. Circuit twice rejected the bubble concept for "non-attainment" states where the Act required improved emissions levels. ${ }^{3}$ The second case, Chevron, U.S.A., Inc. v. Natural Resources Defense Council, ${ }^{4}$ reached the Supreme Court, where the bubble concept got an important conceptual boost from Deputy Solicitor General Paul Bator. Representing the EPA, Bator argued that Congress's purpose was complex - to clean up the nation's air (the lower court's focus), but at a reasonable cost to industry (Shea \& Gardner's focus). Because the statute was fairly open-ended, the EPA had considerable discretion in setting this policy balance, and federal judges should not upset that balance unless the EPA's view was clearly contrary to the statute. ${ }^{5}$

Penned by the first "political" deputy within the Solicitor General's Office, Bator's brief was a roadmap for the relief from excessive regulatory burdens that was a hallmark of the Reagan Administration. Liberal Justice William Brennan was suspicious of Bator's framework, but the Administration caught some lucky breaks as Justices dropped out of the case like flies in a hailstorm. ${ }^{6}$

1. Pub. L. No. 95-95, § 172(b)(6), 91 Stat. 685 (1977) (codified at 42 U.S.C. $\$ 7502(b)(6)$ (2000)).

2. The genesis of the "bubble concept" is based upon conversations with attorneys at the former Shea \& Gardner. Professor Eskridge was an associate at that firm from 1979 to 1982.

3. ASARCO Inc. v. Envtl. Prot. Agency [EPA], 578 F.2d 319, 329-30 (D.C. Cir. 1978) (ruling that the bubble concept was required for programs seeking to preserve existing air quality, but inappropriate in the Clean Air Act program mandating improvement in air quality), followed in Natural Res. Def. Council [NRDC] v. Gorsuch, 685 F.2d 718, 728 (D.C. Cir. 1982).

4. 467 U.S. 837 (1984).

5. On the Bator brief and its background, see Thomas W. Merrill, The Story of Chevron: The Making of an Accidental Precedent, in Administrative Law Stories 398, 413-14 (Peter L. Strauss ed., 2006). See also Ala. Power Co. v. Costle, 636 F.2d 323, 397-401 (D.C. Cir. 1979) (Wilkey, J.) (arguing for the need for courts to allow the EPA regulatory flexibility so that costs are not disproportionate to benefits).

6. Although liberal Justice Brennan voted to affirm the D.C. Circuit, his liberal colleague Thurgood Marshall was absent due to illness. After voting with Brennan to affirm, Justice O'Connor also dropped out of the case because of a potential conflict of interest after her father died. See Memorandum from O'Connor to the Conference, June 14, 1984, in Papers of Harry A. Blackmun, Library of Congress, 
Their biggest break, though, was that the legality of the bubble concept was impossibly complicated for the Court. Apparently the shakiest voice in the original 4-3 conference vote to reverse the D.C. Circuit, Justice Stevens explained his tentative willingness to side with the EPA: "When I am so confused, I go with the agency."7 Encouraged by Justice White, the assigning Justice in the case, Justice Stevens not only accepted Bator's argument of a complex statutory purpose, but endorsed a very broad rule of deference ${ }^{8}$ His opinion for a unanimous Court announced a two-step inquiry. Step one: Has Congress "directly spoken to the precise question at issue"? 9 If so, Congress's directive is controlling. "If, however, the court determines Congress has not directly addressed the precise question at issue, the court [should] not simply impose its own construction on the statute." Instead, the court should move to step two and ask "whether the agency's answer is based on a permissible," or reasonable, "construction of the statute." 10 If so, the court should accept the agency's interpretation.

Just as important as the precise rule was Justice Stevens's broad articulation of the reasons judges should defer. First, when Congress has delegated rulemaking responsibilities to agencies, courts are obligated to go along with those rules unless they are arbitrary, capricious, or contrary to the statute. That was blackletter administrative law, but Stevens added that delegations could be "implicit," and perhaps implemented through means other than rulemaking. "In such a case, a court may not substitute its own construction of a statutory provision for a reasonable interpretation made by the administrator of an agency."11 Second, when an interpretation involves "reconciling conflicting policies," judges must defer to agencies with experience and expert judgment, especially when the regulatory scheme is technical and complex, and the agency considered the matter in a detailed and reasoned manner. ${ }^{12}$ Third, and most originally, agencies are relatively more legitimate policy-balancers than courts, because the executive branch is more "directly accountable to the people." ${ }^{13}$ Thus, when Congress

Madison Building, Box 397, Folder 7 [hereinafter Blackmun Papers]. Also out of the case was Justice Rehnquist, who would probably have been a voice for deference. (As O'Connor mentioned during Conference, the bubble concept was helpful to smelters and other ailing industries in Arizona, her and Rehnquist's home state. See Conference Notes for Chevron, in Blackmun Papers, supra).

7. Conference Notes for Chevron, March 2, 1984, in Blackmun Papers, supra note 6, Box 397 , Folder 7.

8. John Paul Stevens, In Memoriam: Bymon R. White, 116 HaRv. L. Rev. 1, 1-2 (2002) (Justice Stevens's account of the Chevron assignment).

9. Chevron, 467 U.S. at 842.

10. Id. at 843. The neat two-step formula was similar to less structured formulations the Court had previously announced. See, e.g., Beth Israel Hosp. v. Nat'l Labor Relations Bd. [NLRB], 437 U.S. 483, 500-01 (1978) (labor law); Nat'l Muffler Dealers Ass'n v. United States, 440 U.S. 472, 476-77 (1978) (tax); Batterton v. Francis, 432 U.S. 416, 425 (1977) (safety-net programs).

11. Chevron, 467 U.S. at 844.

12. Id. at $844-45,864-65$. This reflected Bator's insight into the New Deal era justification of deference because of agency expertise. See United States v. Shimer, 367 U.S. 374, 383 (1961).

13. Chevron, 467 U.S. at 865. 
(the most accountable branch) has not directly addressed the issue, and the agency has filled the statutory gap in a reasonable way, "federal judges-who have no constituency - have a duty to respect legitimate policy choices made by those who do."14

In short, Justice Stevens not only delivered an opinion that accepted Bator's argument from conflicting statutory policies, but threw in his own argument based on democratic legitimacy. Almost immediately, Reagan Administration officials and appointees proclaimed a "Chevron Revolution." In 1986, D.C. Circuit Judge Kenneth Starr (later Solicitor General) announced that Chevron was a Magna Carta for agencies to deregulate and to demand judicial acquiescence, which his court was prepared to deliver. ${ }^{15}$ Antonin Scalia, Starr's colleague on the D.C. Circuit, announced the same line and pressed a similarly strong reading of Chevron after Reagan appointed him to the Supreme Court. ${ }^{16}$

The "revolution" was not without its critics. Other judges, including thenChief Judge Stephen Breyer of the First Circuit, rejected Starr's broad reading of Chevron as inconsistent with the traditional understanding of the judicial power granted by Article IIII. ${ }^{17}$ Perhaps for this reason, the Reagan and George H.W. Bush Solicitor Generals did not press Chevron nearly as strongly at the Supreme Court level, reportedly out of fear that the Court would clarify Chevron in unhelpful ways, as Justice Stevens tried to do in INS v. CardozaFonseca.$^{18}$ But even Cardoza-Fonseca revealed the rhetorical tilt toward deference. Although the Court invalidated the INS's narrow view of asylum protections and rejected Justice Scalia's broad understanding of Chevron, Justice Stevens's opinion for the Court in Cardoza-Fonseca closed with a concession that the agency had considerable leeway in implementing the asylum standard the Court found in the statute. ${ }^{19}$ Even as they sought to narrow Chevron, the Justices were publicly ceding the details of statutory policymaking to agencies. ${ }^{20}$

14. Id. at $865-66$.

15. Kenneth W. Starr, Judicial Review in the Post-Chevron Era, 3 YALE J. ON REg. 283, 284, 312 (1986).

16. Antonin Scalia, Judicial Deference to Administrative Interpretations of Law, 1989 DUKE L.J. 511, 521; see also Douglas W. Kmiec, Judicial Deference to Executive Agencies and the Decline of the Nondelegation Doctrine, 2 ADMIN. L.J. AM. U. 269, 277 (1988).

17. Stephen Breyer, Judicial Review of Questions of Law and Policy, 38 ADMIN. L. REv. 363, 373 (1986).

18. 480 U.S. 421 (1987); see Thomas W. Merrill, Confessions of a Chevron Apostate, Admin. L. NEws, Winter 1994, at 1, 14 (confessing that the Solicitor General's Office pressed Chevron hard at the D.C. Circuit, but less so at the Supreme Court, lest the Court trim back on its reasoning).

19. Cardoza-Fonseca, 480 U.S. at 448; Letter from Justice Stevens to Justice Blackmun, February 9 , 1987, in Blackmun Papers, supra note 6, Box 466, Folder 6 (rejecting Blackmun's suggestion to give more substance to the statutory "well-founded fear" standard, because there was no consensus among the majority as to what that substance would be).

20. See, e.g., Interstate Commerce Comm'n [ICC] v. Texas, 479 U.S. 450, 457 (1987) (following Chevron to allow ICC discretion in exempting carriers from state taxes); Luckhard v. Reed, 481 U.S. 368, 383 (1987) (Blackmun, J., concurring) (applying Chevron to allow the Department of Health and Human Services [HHS] broad discretion to impose inclusive definition of "income" for purposes of the Aid to Families with Dependent Children [AFDC] program); Chem. Mfrs. v. NRDC, 470 U.S. 116, 135 
Since Cardoza-Fonseca, there has been a doctrinal tug of war within the Supreme Court between Justices Stevens (Chevron's author) and Scalia (the cheerleader for a broad reading). The struggle came to a head in United States $v$. Mead Corp. ${ }^{21}$ The lower court had overturned a Customs Service letter ruling regarding the characterization of an import item for tariff purposes. Rejecting Chevron deference, eight Justices formally ratified Justice Stevens's position that Chevron governed only those cases where the agency was acting under a congressional delegation of lawmaking authority to the agency. ${ }^{22}$ The Mead Court further held that, even when an agency interpretation is not entitled to Chevron deference, its factual and legal arguments are often "entitled to respect" based upon their "power to persuade"-a standard called Skidmore deference, after the leading case. ${ }^{23}$ In his scorched-earth Mead dissent, Justice Scalia argued that Skidmore deference is obsolete and that any interpretation formally adopted by the agency head (except for "litigating positions") is entitled to two-step Chevron deference. ${ }^{24}$

In 2006, the Court again followed the Mead structure, with a twist, in Gonzales v. Oregon. ${ }^{25}$ Finding that the Attorney General had no delegated authority under the Controlled Substances Act of 1970 to preempt Oregon's death-with-dignity law, which allowed doctors to help terminally ill persons bring their lives to closure, the Court held Chevron inapplicable and evaluated (and rejected) the Attorney General's reasons under Skidmore. Again in dissent, Justice Scalia not only argued that the Attorney General was entitled to Chevron deference, but also that he was entitled to Seminole Rock deference, which requires that an agency interpretation of its own regulations be upheld unless

(1985) (following Chevron to allow the EPA to consider plant-specific factors and to allow variances from pretreatment regulations for pollution sources). In all of these cases, the record of the Conference discussions suggests that a broad understanding of deference was the critical factor in the votes of key Justices. See Blackmun Papers, supra note 6, Box 416, Folder 1 (Chemical Manufacturers); id. Box 470, Folder 4 (ICC v. Texas); id. Box 471, Folder 8 (Luckhard).

21. 533 U.S. 218 (2001).

22. Id. at 226-27, 230-33 (2001), followed in Gonzales v. Oregon, 546 U.S. 243, 259 (2006); Nat'1 Cable \& Telecomms. Ass'n v. Brand X Internet Servs., 545 U.S. 967, 980-81 (2005). Mead's understanding reflects a rough scholarly consensus as well. See, e.g., Administrative Conference of the United States, Recommendation 89-5, Achieving Judicial Acceptance of Agency Statutory Interpretations, 54 Fed. Reg. 28,972-73 (July 10, 1989); Robert A. Anthony, Which Agency Interpretations Should Bind Citizens and the Courts?, 7 YALE J. on REG. 1, 4 (1990); Thomas W. Merrill, Rethinking Article I, Section 1: From Nondelegation to Exclusive Delegation, 104 Colum. L. Rev. 2097, 2171 (2004); Henry Monaghan, Marbury and the Administrative State, 83 CoLum. L. REv. 1, 6 (1983) (presciently articulating this view on the eve of Chevron).

23. Mead, 533 U.S. at 227-28 (citing Skidmore v. Swift \& Co., 323 U.S. 134 (1944)). The Mead Court remanded the case to the lower court to evaluate the agency's ruling in light of the Skidmore factors-"the thoroughness evident in [the agency's] consideration, the validity of its reasoning, its consistency with earlier and later pronouncements, and all those factors which give it power to persuade, if lacking power to control." Skidmore, 323 U.S. at 140.

24. Mead, 533 U.S. at 239-61 (Scalia, J., dissenting).

25. 546 U.S. 243 (2006) (The Oregon Aid-in-Dying Case). 
"plainly erroneous or inconsistent with the regulation." ${ }^{26}$ Even though Justice Kennedy's opinion for the Court rejected the application of Seminole Rock, both it and Justice Scalia's dissent assumed that Seminole Rock deference survives and augments Chevron.

Another front of the deference debate was dramatically revealed during the same Term in Hamdan v. Rumsfeld, which invalidated the President's order creating military commissions providing summary justice to alleged "illegal enemy combatants."27 Again writing for the Court, Justice Stevens concluded that the President's order was inconsistent with both the Uniform Code of Military Justice and the Geneva Conventions' assurances of minimal rights for prisoners of war and others. ${ }^{28}$ In dissent, Justice Thomas argued that the Court must give the strongest possible deference to the President's interpretation of his constitutional and statutory authority in times of war. ${ }^{29} \mathrm{He}$ evoked the seminal case Curtiss-Wright, which provides for the executive a "degree of discretion and freedom from statutory restriction [in the field of foreign affairs] which would not be admissible were domestic affairs alone involved." ${ }^{30}$ Only Justice Scalia joined this analysis, however, and the Hamdan majority declined to give the President heightened deference in that case.

This brief tour d'horizon reveals that unpacking the implications of Chevron for Supreme Court jurisprudence is a complicated affair. Other scholars have comprehensively analyzed the doctrinal ins and outs of Chevron, ${ }^{31}$ and a few have surveyed the application of the Court's deference jurisprudence at various times, and at various levels of the federal system. ${ }^{32}$ Our project is a more ambitious endeavor. We conducted an empirical study of all 1014 Supreme Court cases between Chevron and Hamdan in which an agency interpretation of

26. Bowles v. Seminole Rock \& Sand Co., 325 U.S. 410, 414 (1945), followed and elaborated on in Auer v. Robbins, 519 U.S. 452 (1997). Justice Scalia's Oregon dissent therefore terms this "Auer deference."

27. 126 S. Ct. 2749 (2006).

28. Id. at 2789-98.

29. Id. at 2823 (Thomas, J., joined by Scalia, J., dissenting).

30. United States v. Curtiss-Wright Export Corp., 299 U.S. 304 (1936) (upholding the President's action against Curtiss-Wright for selling guns to Bolivia, assertedly in violation of a congressional embargo statute). The holding of the case is supportable under ordinary principles, but Justice Sutherland's opinion went further and has long been controversial. See, e.g., David M. Levitan, The Foreign Relations Power: An Analysis of Mr. Justice Sutherland's Theory, 55 YALE L.J. 467, 496-97 (1946).

31. See, e.g., Michael Herz, Deference Running Riot: Separating Interpretation and Lawmaking Under Chevron, 6 Admin. L.J. AM. U. 187, 189 (1992); Thomas W. Merrill \& Kristin E. Hickman, Chevron's Domain, 89 Geo. L.J. 833, 834-35 (2001).

32. See, e.g., Kristin E. Hickman \& Mathew D. Krueger, In Search of the "Modern" Skidmore Standard, 107 Colum. L. Rev. 1235, 1271-80 (2007) (circuit court application of Skidmore); Orin S. Kerr, Shedding Light on Chevron: An Empirical Study of the Chevron Doctrine in the U.S. Courts of Appeals, 15 YAlE J. ON Reg. 1, 1 (1998) (circuit court application of Chevron); Peter H. Schuck \& E. Donald Elliott, To the Chevron Station: An Empirical Study of Federal Administrative Law, 1990 DuKE L.J. 984, 987 (D.C. Circuit's application of Chevron in selected periods after the decision). Although not empirical, a valuable study of Mead among the lower courts is Lisa Schultz Bressman, How Mead Has Muddied Judicial Review of Agency Action, 58 VAND. L. Rev. 1441 (2005). 
a statute was at issue. In this way, we hoped to marry hard empirical datalacking in the academic discourse on Chevron-with theoretical discussion of the proper role of agency deference in Supreme Court jurisprudence.

Part I of this Article describes the methodology of our study. We explain the means by which we identified cases where the Supreme Court addressed an agency interpretation of a statute, ${ }^{33}$ and then how we coded each case for 156 different variables. ${ }^{34}$

Part II presents our empirical findings. Based upon our data, we conclude that there has not been a Chevron "revolution" at the Supreme Court level. The deference regime associated with the Chevron decision is not completely new and continues to exist alongside old feudal lords-Skidmore, Seminole Rock, Curtiss-Wright, and Beth Israel. ${ }^{35}$ Indeed, from the time it was handed down until the end of the 2005 term, Chevron was applied in only $8.3 \%$ of Supreme Court cases evaluating agency statutory interpretations. As we demonstrate in section II.A, during this time frame, the Court employed a continuum of deference regimes. This continuum is more complicated than the literature or even the Court's own opinions suggest, and it is a continuum in which Chevron plays a modest role. ${ }^{36}$ Indeed, our most striking finding is that in the majority of cases-53.6\% of them-the Court does not apply any deference regime at all. Instead, it relies on ad hoc judicial reasoning of the sort that typifies the Court's methodology in regular statutory interpretation cases.

We then examine, in section II.B, the application of Chevron in depth. To our surprise, we found that the Court usually does not apply Chevron to cases that are, according to Mead and other opinions, Chevron-eligible. Moreover, in analyzing how Chevron is applied in the cases where it is invoked by the Court,

33. Our methodology was simple: We read every case decided between 1984 and 2006 in which an agency interpretation of a statute was at issue and in which the Supreme Court produced a published opinion; if the United States filed a brief interpreting the statute or the Court's opinion (or even a brief in the case) revealed a publicly available agency interpretation on point, we included that case. Statutory interpretation cases where there was no agency interpretation on point were not included. Many of the statutory cases not included were constructions of the federal habeas statute as applied to state prisoners (hence, there was no United States brief unless requested by the Court), but other cases not included were cases where there was, surprisingly, no agency position available. See, e.g., Chan v. Korean Air Lines, 490 U.S. 122, 123-24, 126 n.2 (1989) (providing important interpretation of Warsaw Convention, but without any executive input). Conversely, we included a number of constitutional cases where the Court narrowly construed a statute at the suggestion of the Department of Justice. See, e.g., Morrison v. Olson, 487 U.S. 654 (1988).

34. The dataset is available on-line through The Georgetown Law Journal. See The Georgetown Law Journal, http:/www.georgetownlawjournal.com/extras/96.4/ (last visited Mar. 18, 2008). An Appendix to this Article reproduces our Codebook, which explains our methodology.

35. See the discussion above for a description of Skidmore, Seminole Rock, and Curtiss-Wright. Beth Israel is a category we have devised for post-Chevron Supreme Court opinions that announce a special deference regime (often in the field of labor) and apply a reasonableness analysis similar to that in Chevron, but without citing Chevron (or a Chevron-following case), instead citing to and following a pre-Chevron deference case like Beth Israel Hosp. v. NLRB, 437 U.S. 483 (1978).

36. Cf. Schuck \& Elliott, supra note 32, at 1057 (finding that the courts of appeals not only cited Chevron repeatedly, but also that agency interpretations prevailed more often). 
we found little doctrinal consistency. There is some indication that while congressional delegation is not a solid predictor of when the Court will invoke Chevron, it is correlated with, and may influence, the agency's chances of prevailing once Chevron has been invoked. And there is clear evidence that where Chevron is invoked, legislative history remains relevant to the two-step inquiry. However, explanations for why the Court chose to invoke Chevron when it did, and how the Court applied Chevron once invoked, were not apparent from the data.

In section II.C we examine the predictive capacity of our data. Specifically, we ask: Are there factors that predict (1) when particular deference regimes will be invoked, and (2) when the agency is more likely to win? As to the first question, our data offer little to latch onto; there is no clear guide as to when the Court will invoke particular deference regimes, and why. As to the second question, our data were somewhat more helpful. Based upon the academic literature, we expected to find that high agency win rates would be positively associated with (1) the application of Chevron or Seminole Rock deference; (2) an open, legitimate process such as notice-and-comment rulemaking or formal adjudication; and (3) the absence of a plain statutory meaning (which leaves more room for agency discretion). We found some positive correlation with the first two factors, but none with the third. Based upon our own experience, we expected to find that high agency win rates would also be positively associated with (1) statutory subject matter and comparative agency expertise; and (2) agency consistency in adhering to the interpretation over time. Both hypotheses bore out. As a separate point, we also found (3) a strong association between judicial ideology and the likelihood of liberal or conservative agency interpretations prevailing, with liberal justices more likely to support liberal agency interpretations, and conservative justices more likely to support conservative agency interpretations.

In Part III we turn to normative questions: Is this complicated regime defensible? To what extent and under what circumstances should the Court defer to agency interpretations of federal statutes and regulations? Our main suggestion is that the degree of deference the Supreme Court ought to afford an agency interpretation of the statute it is applying should be driven by three variables: (1) whether the agency interpretation is made pursuant to a congressional delegation of lawmaking authority (Chevron/Mead), (2) whether the agency is applying special expertise and using its understanding of the facts to carry out congressional purposes (Skidmore), and (3) whether the agency interpretation is consistent with larger public norms, including constitutional values (Oregon). Although our empirical study suggests caution about the Court's collective ability to follow any doctrinal framework consistently, we close with some suggestions for the Justices to consider as regards the continuum of deference regimes that they have followed in the last generation.

First, simplification. Although the complicated and unevenly applied deference continuum is working fine for deciding cases before the Supreme Court, 
this is not a satisfactory regime for providing guidance to lower courts, legislators, agencies, and the citizenry. The Court should simplify the continuum along the following lines:

- Chevron's special deference regime should apply where Congress has delegated lawmaking authority to an executive or independent agency or to the President;

- Skidmore should be the default regime under which the Court considers agency inputs, with those inputs being especially valued when (a) the agency has expertise on issues as to which judges do not; (b) the agency has rendered a reasoned judgment after input from the public; and/or (c) there has been public or private reliance on agency rules or guidances;

- Oregon anti-deference ought to be the baseline when the agency interpretation (a) represents a fundamental change in statutory policy; (b) extends criminal liability; or (c) raises serious constitutional problems.

The Court ought to apply this simplified continuum more consistently, especially as regards special Chevron deference; our study illustrates the difficulty of consistent application but also some possible strategies for improvement.

Second, institutional dialogue and balance. The Court's deference jurisprudence helps structure the process by which statutes are elaborated and developed by agencies and might, under some circumstances, affect Congress's agenda and structure. For example, we join other scholars in encouraging the Court to explicitly recognize the greater legitimacy of notice-and-comment ("legislative") rulemaking pursuant to congressional delegation as the model for Chevron deference. This would encourage agencies to elaborate statutory policy through a process that is more legitimate, though more time-consuming and costly. If that baseline were more transparent, agencies would have a clearer idea as to the availability of special deference and Congress would have a better idea about the different effects of different kinds of statutory delegations. Our concern for balanced governance is mobilized by our empirical finding that agency interpretations prevail most frequently (usually under a Skidmore standard or less) in areas where the Justices perceive themselves as least competent to handle the substantive issues, areas such as pension, bankruptcy, health, and intellectual property. Agency inputs are critically important in these areas, but are also potentially biased; in bankruptcy, for example, the federal government is often a creditor, and its amicus briefs often reflect a pro-creditor policy bias. For reasons of institutional balance, the Supreme Court or the Judicial Conference ought to create a trial process whereby public-interested amicus briefing is sought from another source, and not just the Solicitor General.

Third, modernization. The Court ought to recognize, expressly, that statutory interpretation doctrine needs to be understood through a new lens, that of the modern administrative state. Such a lens requires fresh conceptualization of such judicial doctrines as the plain-meaning rule, purposive interpretation, 
legislative history, stare decisis, and the substantive canons of statutory construction. For example, our study has important implications for the contentious debate over whether the Court should rely on legislative history: the data establish that the Justices in fact consistently rely on such history in agencyinterpretation cases; our reading of the briefs as well as opinions suggests that agencies provide useful accounts of that history; and our normative framework indicates that legislative history provides legitimating links between original enactments and new applications. Indeed, consulting legislative history is the only mechanism that shows any (tentative) promise for ameliorating the ideological voting that our dataset reveals.

\section{Methodology}

Even though Chevron is often described as having revolutionized the jurisprudence of agency deference, relatively few studies have attempted to empirically examine the application of the Chevron doctrine, and none has attempted to examine the Supreme Court's Chevron jurisprudence systematically in light of the entire universe of potential deference cases. Those studies that have focused on Chevron can be described as partial or incomplete, at best. Some studies examine cases only from small, discrete time periods. ${ }^{37}$ Others limit their examination to judicial review of actions taken by particular agencies. ${ }^{38}$ Still others attempt to quantify the impact of Chevron by examining only those cases in which judges explicitly cite or invoke Chevron. ${ }^{39}$ None has employed random sampling.

Given these features, previous studies are of limited value. Studies of small, discrete periods of time may not be representative of the Court's overall practice. Studies that attempt to extrapolate from cases involving only a few agencies raise questions about whether those cases are representative of the Court's deference jurisprudence or anomalous to it. And studies that only include those cases in which a particular deference regime is employed ignore critical questions about when and why the regime is invoked and what is

37. See Schuck \& Elliott, supra note 32 (examining appeals court cases involving "judicial review of federal administrative action" in four discrete six-month periods in 1965, 1974-75, 1984, and 1985, and one two-month period in 1988); Eric R. Womack, Into the Third Era of Administrative Law: An Empirical Study of the Supreme Court's Retreat from Chevron Principles in United States v. Mead, 107 Dick. L. REv. 289, 290 (2002) (examining federal court cases in the six months directly following the Supreme Court decision in Mead and occasionally comparing them to federal court cases in the year prior to Mead).

38. See Richard Revesz, Environmental Regulation, Ideology, and the D.C. Circuit, 83 VA. L. Rev. 1717, 1721 (1997) (examining all cases decided by the D.C. Circuit between 1970 and 1996 that challenged the health and safety decisions of twenty federal agencies); see also Thomas J. Miles \& Cass R. Sunstein, Do Judges Make Regulatory Policy? An Empirical Investigation of Chevron, 73 U. ChI L. Rev. 823, 825 (2006) (examining published appeals court decisions from 1990-2004 in which federal judges reviewed interpretations of law by the EPA and NLRB).

39. See Kerr, supra note 32 , at 4 (examining every application of the Chevron doctrine in the courts of appeals during 1995 and 1996); Miles \& Sunstein, supra note 38, at 825 (examining eighty-four Supreme Court cases applying the Chevron doctrine, sixty-nine of which cite Chevron directly). 
happening in the cases where it is not applied.

Our study attempts to fill this empirical gap and provide a more comprehensive analysis of Supreme Court deference practice. ${ }^{40}$

The dataset for this study consists of all Supreme Court cases decided between Chevron (1983 Term) and Hamdan (2005 Term) in which a federal agency interpretation of a statute was at issue, 1014 in all. ${ }^{41}$ Each case was coded for 156 variables. The variables ranged from basic descriptive information about the statute and agency in play to more nuanced information about the form, continuity, and legal force of the agency interpretation. We recorded the voting record of each Justice and the form(s) of reasoning employed in each majority, concurring, and dissenting opinion. ${ }^{42}$

Each variable and its coding criteria are described, often in some detail, in the Appendix, which reproduces the Codebook explaining our methodology. Some variables are easy to code, such as the name of the case, the citation reference, the agency whose interpretation the Court considered, and so forth. Other variables involve matters of informed judgment. Where that is the case, the Codebook provides a detailed account of how we applied that informed judgment and often gives representative examples. For example, we coded agency and judicial interpretations for ideology, including "liberal," "conservative," or "mixed." We have generally followed conventional criteria, explicitly identified for each subject area in the Codebook. Thus, we coded bankruptcy act interpretations favoring debtor interests as "liberal," and interpretations favoring creditor interests as "conservative." 43

Our primary concern is with two response variables: (1) what deference regime the Court invoked, and (2) whether the Court ultimately agreed with the agency interpretation. Although they sound quite similar, these variables are important to distinguish. Thus, "deference regime invoked" refers to the analytical framework, if any, used by the Court to evaluate or weigh an agency

40. For an excellent model that provided us with guidance, see James J. Brudney \& Corey Ditslear, Canons of Construction and the Elusive Quest for Neutral Reasoning, 58 VAND. L. REv. 1, 59-63 (2005). Like earlier studies of Supreme Court cases, ours cannot make strong assertions about some issues because of selection biases-namely, the likelihood that the cases available for Supreme Court review will change over time in response to the Court's deference jurisprudence. For example, Thomas W. Merrill, Judicial Deference to Executive Precedent, 101 YALE L.J. 969, 981-84 (1991), reported that agency interpretations prevailed at the Supreme Court $75 \%$ of the time in the three years before Chevron, but only $70 \%$ in the six years after Chevron. This interesting finding, similar to those that we report, does not mean that Chevron failed to induce greater deference among lower court judges or even Supreme Court Justices, because the post-Chevron cases might have been skewed in favor of challengers, with agency victories going largely unappealed and government attorneys emboldened to take appeals in weaker cases than they had done pre-Chevron.

41. This number does not include the Chevron decision itself, which was also coded but is not included in our statistical analysis.

42. Coding of all 1014 cases was done by one author, thereby eliminating the coding inconsistencies that often arise when multiple coders are used. As a further safeguard, the other author then crosschecked all coding for internal consistency and errors.

43. See infra Appendix 1: Codebook, "Agency Interpretation," Note. The Note identifies our litmus test for each area of law represented in our dataset. 
interpretation. It records the logical framework the Court used to build its reasoning (for example, the Chevron two-step inquiry, the Skidmore all-thingsconsidered approach, etc.). Section II.A describes each of the deference regimes we found. The Codebook in the Appendix goes into great detail explaining our criteria for designating a case as falling within each deference regime identified in section II.A. ${ }^{44}$

In contrast, "agreement with the agency interpretation" refers to whether the Court ultimately upheld the statutory interpretation put forth by the agency. Did the agency win? (In contrast with the previous variable, this one was easy to code.) It is critical to note that even when the Court invokes a deference regime, the agency position does not always prevail. Applying Chevron (or any other deference regime), the Court might still reject the agency interpretation if the standards set forth by any particular test are not met. Conversely, even when the Court applies no deference regime, the agency interpretation might still prevail, because the Court believes, upon its own independent examination, that the agency interpretation was correct as a matter of law.

The breadth of data collected in our study enables us to paint a thorough and complex picture of the many factors affecting the Court's invocation of different deference regimes and its decision to defer to agency interpretations. ${ }^{45}$ Further, because our dataset consists of the entire population of cases of interest to us, and not a sample of cases from the population, the data we provide in this Article consist not of sample statistics, but rather of actual population parameters. As a result, for most issues there is no need to conduct significance tests on the basic summary figures we lay out. Such tests show that the likelihood that variations between sample statistics are due to actual variation in the population and not random variation within the sample. Here, we can report with one hundred percent certitude that the variations we describe exist in the population at hand, and therefore we can spend our time on the more interesting endeavor of postulating why these variations are there and whether they are meaningful.

Despite the strengths of our study, there are important methodological limitations to it. First, even though there is no need to run significance tests on our findings, there is a need to determine whether observed variations are "significant"- that is, whether they offer any meaningful insight into the Court's deference practice. This is a matter of judgment, and we are sensitive to the fact that our interpretations of significant differences between different values may be influenced by our own hypotheses about what is driving the Court's behavior. That said, we have attempted to be as objective as possible in attributing significance to the observed differences in various population parameters. When we make comparisons within a given area, we establish standards for what

44. See id., "Deference Regime Invoked," Note.

45. We also examine the extent to which these variables interact with each other-that is, whether the deference regime invoked has an impact on how frequently agency interpretations are upheld, and whether the Court's desire to uphold certain agency interpretations may influence the deference regime it chooses to invoke. 
magnitude of variation will count as significant, and when we deviate from these standards, we explain why, noting whether our reasoning is mathematical (for example, an extremely small subgroup), or theoretical (for example, external knowledge about the Court's practice), or both. We also explain why we take note of seemingly minor variations in some areas, while glancing over seemingly larger variations in others. We aim to be as transparent as possible in our reasoning, knowing that some methodological disagreement will be inevitable, and welcoming the debate that such disagreement will cause.

Second, we do not develop a statistical model to explain the Court's behavior in invoking different deference regimes and evaluating agency interpretations of statutes. One reason for not modeling the Court's approach is that the raw data have so much to tell. Given the large number of variables we examined, there is a huge quantity of information to report just about the population parameters. Indeed, this Article does not report more than a fraction of the parameters determinable from our dataset. Further, given the current dearth of empirical work on the Supreme Court's deference practice, there is a value to reporting these parameters alone. They can inform future work, both empirical and theoretical, and act as a starting point for more in-depth quantitative analysis at a later point. Most importantly, we are somewhat skeptical of the value added from modeling the Court's deference practice. Our judgment is that any formal model would be incomplete, at best, and unable to control for the innumerable, uncodable factors that influence judicial decisionmaking. We are comfortable reporting on trends in deference practice grounded in empirical data, but less warm to the idea (or value) of reporting such manufactured facts as the percentage variation in deference regime due to subject area, or delegation of lawmaking authority, or any of the other 156 items of which we took note.

Third, we examined only Supreme Court cases, not cases in the courts of appeals. As many scholars have correctly pointed out, in terms of the number of cases at issue, the courts of appeals are the primary venue for judicial review of agency interpretations. Given its discretionary jurisdiction over appeals and the Justices' disinclination to exercise that discretion, the Supreme Court reviews only a small percentage of agency interpretations that make their way through the federal court system. ${ }^{46}$ Relatedly, the agency-interpretation cases that come before the Supreme Court are not representative of the cases that come before the courts of appeals. As we explain in section II.C, there are several selection

46. In the time frame examined in this study (1983 to 2005) the number of agency-interpretation cases reviewed by the Supreme Court dropped from a high of 66 cases the term after Chevron was decided, to 38 cases in the 2005 term. The precise breakdown of cases, by term, is as follows: 1983 term, after and including Chevron, 17 cases; 1984 term, 66 cases; 1985 term, 56 cases; 1986 term, 57 cases; 1987 term, 57 cases; 1988 term, 49 cases; 1989 term, 47 cases; 1990 term, 51 cases; 1991 term, 46 cases; 1992 term, 62 cases; 1993 term, 41 cases; 1994 term, 35 cases; 1995 term, 36 cases; 1996 term, 41 cases; 1997 term, 49 cases; 1998 term, 43 cases; 1999 term, 31 cases; 2000 term, 36 cases; 2001 term, 42 cases; 2002 term, 38 cases; 2003 term, 42 cases; 2004 term, 35 cases; and 2005 term, 38 cases. 
effects that flow from the fact that the Supreme Court has discretionary review and takes a small percentage of appeals while the courts of appeals are required to hear almost all the appeals falling within their jurisdiction. As a consequence, the Supreme Court will hear cases that present tougher legal issues. Even less predictable is the effect of the much-touted "Chevron Revolution" (or the perception of such a revolution) on the kinds of cases that are litigated and appealed into the federal courts generally, as well as at the Supreme Court level. ${ }^{47}$

That said, we believe that the Supreme Court is where any analysis of agency deference ought to begin. The Court, of course, develops deference tests that are applicable throughout the federal judiciary. Therefore, we can assume that, of all courts, its practice would be particularly well-informed and, perhaps, internally consistent. More important, the appeals courts look to the Supreme Court for guidance. The Supreme Court devises deference tests, defines their parameters, and provides definitive applications of those tests-all of which are binding on the courts of appeals. Lower court judges presumptively follow the Court's lead, to the extent that a "lead" can be discerned. ${ }^{48}$ If our empirical study illuminates the Court's precise practice, it provides useful information to lower court judges (and perhaps to Supreme Court Justices themselves). Our focus on the Supreme Court does not deny the importance of the courts of appeals, and we may conduct similar studies at the appellate level in the future. Rather, it is merely indicative of the fact that, in our calculus, studying the Supreme Court is logically prior to studying the courts of appeals.

In the next Part, we provide a comprehensive analysis of the Supreme Court's deference practice over the past quarter century. Part III evaluates the Court's complicated deference jurisprudence and makes some suggestions for reform.

\section{Empirical Findings: The Supreme Court's ContinuUm of Deference Regimes, Its Application of Those Regimes, and Regularities IN Agency WiN RATES}

Mead, Oregon, and Hamdan (and their dissenting opinions) suggest that there are many issues Chevron left unresolved. Does Chevron supplant previous deference regimes, such as Skidmore, or co-exist along side them? After Mead, is Chevron deference limited to cases where the agency is acting pursuant to a congressional delegation of lawmaking authority? Should the Court defer to an agency's interpretation of its own jurisdiction or lawmaking authority? Is there

47. One would expect that the perception of a Chevron Revolution would have discouraged litigants from challenging some legally vulnerable agency interpretations that would have been challenged under a regime perceived to be more skeptical, while agencies would be encouraged to defend a broader array of interpretations they might have abandoned under the previous regime.

48. If, on the one hand, the Court is establishing formalist tests for deference, but, on the other hand, applying them infrequently and inconsistently, then we might expect appeals court practices to be similarly haphazard. At the very least, we would need to know this before being able to analyze whether deference practice at the appeals court level is "normal" or "deviant." 
special super-deference when agencies are interpreting their own prior regulations or acting on foreign affairs or national security matters? How does Chevron interact with various substantive canons of statutory interpretation?

These are doctrinal questions. What the Court says is relevant to answering them. But so is what the Court does. Our empirical study looked at the latter issue-the Court's practice - and the extent to which it confirms, contradicts, or raises'new questions about the former issue-the Court's stated approach. As it turns out, the gulf between actions and words is, in some places, quite large. Our descriptive analysis starts with the continuum of deference regimes the Supreme Court has explicitly or (for one regime) implicitly invoked in cases where an agency has interpreted the statutory provision in suit. Although there is clearly such a continuum, the Court is wildly inconsistent in applying any of the regimes, including and especially the Chevron regime, which plays a surprisingly modest role in the Court's deference jurisprudence. We do find regularities in the Court's treatment of agency interpretations, but those regularities owe more to functional and political factors than to deference doctrine.

\section{A. THE SUPREME COURT'S CONTINUUM OF DEFERENCE REGIMES}

Contrary to Justice Scalia's Mead dissent, the Court has at no point followed a Chevron-or-nothing approach. But the Chevron-or-Skidmore dichotomy suggested by the Mead majority is only somewhat more reflective of the Court's practice. Instead, our study of the 1014 agency-interpretation cases from Chevron to Hamdan reveals that the Court's deference practice functions along a continuum, ranging from an anti-deference regime reflected in the rule of lenity to the super-strong deference the Court sometimes announces in cases related to foreign affairs. The continuum we found is as follows:

- Curtiss-Wright Deference, the super-deference afforded to executive interpretations involving foreign affairs and national security;

- Seminole Rock Deference, a strong form of deference afforded to agency interpretations of their own regulations;

- Chevron Deference, the famous two-step approach that permits reasonable agency interpretations so long as the statute has not clearly spoken to the issue;

- Beth Israel Deference, the pre-Chevron test permitting reasonable agency interpretations that are consistent with the statute;

- Skidmore Deference, giving agency interpretations respect proportional to their power to persuade;

- Consultative Deference, where the Court, without invoking a named deference regime, relies on some input from the agency (for example, amicus briefs, interpretive rules or guidance, or manuals) and uses that input to guide its reasoning and decisionmaking process; and

- Anti-Deference, which invokes a presumption against the agency inter- 
Table 1. The Supreme Court's Continuum of Deference

\begin{tabular}{|c|c|c|c|}
\hline $\begin{array}{l}\text { Deference } \\
\text { Regime }\end{array}$ & Form of Deference & $\begin{array}{l}\text { Percentage of } \\
\text { Cases in } \\
\text { Population }\end{array}$ & $\begin{array}{c}\text { Agency Win } \\
\text { Rate }\end{array}$ \\
\hline No Deference & Ad hoc judicial reasoning & $53.6 \%$ & $66.0 \%$ \\
\hline Anti-Deference & $\begin{array}{l}\text { The Court invokes a presumption } \\
\text { against the agency interpretation } \\
\text { in criminal cases (the rule of } \\
\text { lenity) and in some cases in } \\
\text { which the agency interpretation } \\
\text { raises serious constitutional } \\
\text { concerns (the canon of } \\
\text { constitutional avoidance) }\end{array}$ & $6.8 \%$ & $36.2 \%$ \\
\hline $\begin{array}{l}\text { Consultative } \\
\text { Deference }\end{array}$ & $\begin{array}{l}\text { The Court, without invoking a } \\
\text { named deference regime, relies } \\
\text { on some input from the agency } \\
\text { (e.g. amicus briefs, interpretive } \\
\text { rules or guidance, or manuals) } \\
\text { and uses that input to guide its } \\
\text { reasoning and decisionmaking } \\
\text { process }\end{array}$ & $17.8 \%$ & $80.6 \%$ \\
\hline Skidmore & $\begin{array}{l}\text { Agency interpretation is entitled } \\
\text { to "respect proportional to its } \\
\text { power to persuade," with such } \\
\text { power determined by the } \\
\text { interpretation's "thoroughness, } \\
\text { logic and expertness"; its "fit } \\
\text { with prior interpretations"; etc. }\end{array}$ & $6.7 \%$ & $73.5 \%$ \\
\hline Beth Israel & $\begin{array}{l}\text { Pre-Chevron test permitting } \\
\text { reasonable interpretations that } \\
\text { are consistent with the statute }\end{array}$ & $4.8 \%$ & $73.5 \%$ \\
\hline Chevron & $\begin{array}{l}\text { Reasonable agency } \\
\text { interpretations of ambiguous } \\
\text { statutes accepted. If the statute is } \\
\text { clear, no deference to agency }\end{array}$ & $8.3 \%$ & $76.2 \%$ \\
\hline Seminole Rock & $\begin{array}{l}\text { Strong deference afforded to an } \\
\text { agency's interpretations of its } \\
\text { own regulations }\end{array}$ & $1.1 \%$ & $90.9 \%$ \\
\hline Curtiss-Wright & $\begin{array}{l}\text { Super-strong deference to } \\
\text { executive interpretations } \\
\text { involving foreign affairs and } \\
\text { national security }\end{array}$ & $0.9 \%$ & $100.0 \%$ \\
\hline
\end{tabular}


pretation in criminal cases and in some cases in which the agency interpretation raises serious constitutional concerns.

Table 1, on the previous page, presents these deference regimes, the percentage of the Court's deference cases that they constitute, and the agency win rate under each regime. ${ }^{49}$

Table 1 presents what was, for us, a most unexpected finding: a majority of the Court's cases involving an agency interpretation of a federal statute do not invoke any deference regime, not even the informal "consultative deference" regime we identified. Indeed, in a whopping $53.6 \%$ of the cases studied, the Court eschews formal or informal deference tests in favor of ad hoc judicial reasoning. Somewhat less surprising in light of previous studies, we also find that agency interpretations prevail $68.3 \%$ of the time before the Supreme Court. $^{\text {so }}$

This section explains six of the seven deference regimes (all but Chevron) in full and offers some insight into the reasoning behind the Court's choice of a particular deference regime. Section II.B examines the Chevron regime in even greater detail and demonstrates that the Court's ad hocness in the less-celebrated regimes extends to its inconsistent application of Chevron as well. In section II.C, we add complexity to this analysis by noting how the choice of deference regime seems to affect the rate at which agency interpretations are upheld.

\section{Curtiss-Wright Super-Deference in Foreign Affairs/National Security}

We begin with the strongest form of deference we encountered: super-strong deference to executive department interpretations in matters of foreign affairs and national security. We call this regime Curtiss-Wright deference after the famous 1936 decision in which the Court held that "congressional legislation ... within the international field must often accord to the President a degree of discretion and freedom from statutory restriction which would not be admissible were domestic affairs alone involved." ${ }^{51}$ The source of this discretion in statutory enforcement is the inherent power of the President to represent the nation in foreign matters and to protect America's security interests.

Curtiss-Wright deference is distinguishable from Chevron deference. Because it rests in part upon the President's Article II powers, rather than just on Congress's Article I authority, Curtiss-Wright deference does not depend upon a statutory delegation of lawmaking responsibilities, although the power of its

49. The tables in this Article employ the terms and coding schema explicated in our Codebook, which is attached as an appendix.

50. For earlier studies finding high agency win rates at the Supreme Court level, see Martha Anne Humphries \& Donald R. Songer, Law and Politics in Judicial Oversight of Federal Administrative Agencies, 61 J. PoL. 207, 208-10 (1999); Reginald S. Sheehan, Federal Agencies and the Supreme Court: An Analysis of Litigation Outcomes, 1953-1988, 20 AM. PoL. ScI. Q. 478, 480-82 (1992).

51. See United States v. Curtiss-Wright Exp. Corp., 299 U.S. 304, 320 (1936). 
presumption would be augmented by such delegation. ${ }^{52}$ Moreover, the CurtissWright rule is a more deferential standard than Chevron: the executive department interpretation prevails not only in cases of statutory ambiguity, but also in cases where Congress has not clearly trumped the agency or presidential construction.

Curtiss-Wright deference was important long before Chevron, ${ }^{53}$ and our study establishes that it survives Chevron as well. For example, the Court in Department of the Navy v. Egan ruled against judicial review of presidential revocation of security clearances. ${ }^{54}$ Given the President's broad powers to protect national security and conduct foreign policy, the Court reasoned that, "unless Congress specifically has provided otherwise, courts traditionally [should be] ... reluctant to intrude upon the authority of the Executive in military and national security affairs." 55

Surprisingly, even with a sizeable docket of cases that touch on foreign affairs and national security (93 cases out of 1014 , or $9.2 \%$ ), it remains a rarity for the Court to announce super-strong deference as it did in Egan. Indeed, we identified only nine post-Chevron cases where the Court openly applied superstrong deference of this sort. ${ }^{56}$ In each case, the executive interpretation won, providing a perfect $100 \%$ win rate for the government.

In our judgment, this win rate is inflated, albeit only somewhat, due to a strong selection bias. Curtiss-Wright deference is invoked only in cases where the Court is going along with the executive department and wants to make a statement about the President's broad authority in foreign affairs, while it is

52. Cf. Youngstown Sheet \& Tube Co. v. Sawyer (The Steel Seizure Case), 343 U.S. 579, 635-38 (1952) (Jackson, J., concurring) (President acting under direct statutory authorization has maximum authority; President acting contrary to statutory directive has minimal authority; President acting in a "twilight zone" with neither statutory authority nor contrary directive has authority to act commensurate with his inherent powers and whatever powers Congress has implicitly accorded him in the past).

53. For example, it helps explain the Supreme Court's decision in Dames \& Moore v. Regan, 453 U.S. 654 (1981). In that case, the Court held that an executive agreement suspending hundreds of lawsuits against the Islamic Republic of Iran and creating an international claims tribunal to handle them did not violate the Foreign Sovereign Immunity Act of 1976 (FSIA). Id. at 686. The Court grounded this dynamic interpretation of the FSIA in the President's inherent Article II powers, and in Congress's acquiescence to the exercise of these powers, even in the face of the FSIA. Id. at 680-83.

54. 484 U.S. 518, 530, 534 (1988); accord Sale v. Haitian Ctrs. Council, Inc., 509 U.S. 155, 188 (1993) (invoking President's foreign affairs power as one reason to defer to his interpretation of immigration laws); CIA v. Sims, 471 U.S. 159, 169-71 (1985) (invoking executive national security authority as reason to defer).

55. Egan, 484 U.S. at 529.

56. In addition to Egan, the cases are as follows: Jama v. Immigration \& Customs Enforcement [ICE], 543 U.S. 335, 348 (2005) (strongly deferring to executive branch construction of immigration law); Cheney v. U.S. Dist. Court, 542 U.S. 367, 385-86 (2004) (deferring to high executive branch official resisting discovery on national security grounds); Crosby v. Nat'l Foreign Trade Council, 530 U.S. 363, 375-76 (2000) (international trade); Immigration \& Naturalization Serv. [INS] v. AguirreAguirre, 526 U.S. 415, 425 (1999) (immigration); Reno v. Flores, 507 U.S. 292, 309,312 n.8 (1993) (immigration); Sale v. Haitian Ctrs. Council, Inc., 509 U.S. 155, 188 (1993) (immigration and protection of national borders); Carlucci v. Doe, 488 U.S. 93 (1988) (national security, invoking and following Egan); INS v. Abudu, 485 U.S. 94, 110 (1988) (immigration). 
ignored in those few national security or foreign affairs cases where the Court is disposed to be skeptical of the President's exercise of authority. Indeed, this is exactly what happened in Hamdan: Justice Thomas's dissent was structured around Curtiss-Wright super-deference, while Justice Stevens's majority opinion ignored it. ${ }^{57}$ Furthermore, even though few of the ninety-three cases whose subject matter involved foreign affairs and national security directly cited Curtiss-Wright or announced super-deference, the executive's interpretation prevailed $78.5 \%$ of the time. This is less than the perfect record in the cases explicitly applying a super-deference regime, but still mighty high, especially in light of the human rights issues often implicated in immigration cases, which were the largest portion of this subject-matter category.

In short, this is an arena where the Court's practice has been highly deferential, even when the Justices do not explicitly invoke Curtiss-Wright. Indeed, some decisions are incomprehensible unless thought of as implicit applications of Curtiss-Wright's super-strong deference. ${ }^{58}$ One example is United States v. Alvarez-Marchain. ${ }^{59}$ The Court upheld federal jurisdiction to try a suspect whom the United States had kidnapped in Mexico and brought to this country for criminal trial. Mexico filed a protest that this violated its extradition treaty with the United States. Under ordinary principles of statutory interpretation, those arguments would probably have carried the day, ${ }^{60}$ but a majority went along with the Administration on this matter, given longstanding judicial acquiescence in executive kidnappings like this one. ${ }^{61}$ As noted above, there are a fair number of cases like Alvarez-Marchain, where the Court says nothing about deference but goes along with legally weak executive department arguments in cases involving foreign affairs or national security. ${ }^{62}$ Although these cases are not coded as Curtiss-Wright deference under our coding schema, they support what our Curtiss-Wright category of cases stands for: the notion that superstrong deference to the government in the areas of foreign affairs and national security remains a prominent part of the Court's deference practice.

57. Hamdan v. Rumsfeld, 126 S. Ct. 2749, 2825 (2006) (Thomas, J., dissenting) (invoking CurtissWright super-deference to support the President's military commissions); see also Webster v. Doe, 486 U.S. 592, 614-15 (1988) (Scalia, J., dissenting) (invoking Curtiss-Wright super-deference to argue for no judicial review of executive dismissals of law enforcement personnel).

58. See, e.g., Dames \& Moore, 453 U.S. at 654; discussion supra note 53.

59. 504 U.S. 655, 669, 670 (1992) (interpreting Mexican-American extradition treaty to allow international kidnapping by executive department without extradition duty).

60. See id. at 670 (Stevens, J., dissenting) (powerfully analytical dissent critiquing the Chief Justice's legal arguments).

61. See, e.g., Ker v. Illinois, 119 U.S. 436, 440 (1886) (ruling that executive kidnapping of criminal defendants abroad and bringing them to this country for trial is not unconstitutional).

62. See, e.g., Ministry of Def. for Islamic Republic of Iran v. Elahi, 546 U.S. 450 (2006) (sovereign immunity); Am. Ins. Ass'n v. Garamendi, 539 U.S. 396, 401 (2003) (executive agreement preemption); Itel Containers Int'l Corp. v. Huddleston, 507 U.S. 60, 75-76 (1993) (state tax on international businesses); INS v. Elias-Zacarias, 502 U.S. 478, 484 (1992) (immigration); Dooley v. Korean Air Lines Co., 524 U.S. 116 (1998) (death on the high seas). 
2. Seminole Rock Strong Deference for Agency Interpretation of Its Own Regulations

In Bowles v. Seminole Rock \& Sand Co., the Court ruled that an agency interpretation of its own properly issued regulation is "controlling ... unless it is plainly erroneous or inconsistent with the regulation." ${ }^{63}$ Like Chevron, Seminole Rock empowers agencies vested with lawmaking authority by Congress. Beyond Chevron, Seminole Rock recognizes the practical reality that an agency interpretation of its own (valid-under-the-statute) concept or complex web of regulations should be followed by judges unless there is a strong statutory reason to reject it. In Auer v. Robbins, for example, the Supreme Court ruled that the Department of Labor was entitled to such strong deference when it was elaborating on a legal concept that was a "creature of the [agency's] own regulations." ${ }^{64}$ Likewise, in Thomas Jefferson University v. Shalala, the Court ruled that the Department of Health \& Human Service's (HHS) interpretation of its own complicated regulatory scheme was entitled to the special deference that Seminole Rock affords. ${ }^{65}$

A particularly interesting invocation of this deference approach is Geier $v$. American Honda Motor Co. ${ }^{66}$ The Court ruled that the National Traffic and Motor Vehicle Safety Act of $1966^{67}$ and an agency standard adopted pursuant to the Act implicitly preempted state tort law. ${ }^{68}$ The federal law, as applied by the Department of Transportation in the period in suit, did not require airbags. Writing for a closely divided Court, Justice Breyer's opinion concluded that state tort law requiring airbags conflicted with that federal policy and so had to yield. ${ }^{69}$ The primary reason for finding preemption was that the Department's explanation for the airbag-optional standard was strongly inconsistent with such an aggressive operation of state tort law. ${ }^{70}$ Concluding his opinion (and citing Auer), Justice Breyer placed "some weight" on the Department's view that the state tort law was in fact in conflict with the regulatory objectives of its own standard. $^{71}$

As these cases reflect, Seminole Rock survives Chevron. But Seminole Rock deference is just as episodically invoked as Curtiss-Wright (or Chevron, as we shall subsequently demonstrate). Between 1984 and 2006, the Court wrote decisions in 155 cases where an agency was construing its own regulations. However, we identified only eleven of those cases as ones where the Court

63. 325 U.S. 410,414 (1945).

64. 519 U.S. 452, 461 (1997) (upholding a Department of Labor interpretation of its own regulatory concept embodied in Fair Labor Standards Act regulations).

65. 512 U.S. 504, 512 (1994) (upholding HHS's interpretation of its own complicated Medicare regulations).

66. 529 U.S. $861(2000)$.

67. 80 Stat. 718 (1966) (codified at 15 U.S.C. $\S 1381$ et seq.) (repealed 1994).

68. Geier, 529 U.S. at 886.

69. Id. at 874-75.

70. Id. at $874-81$.

71. Id. at 883-84. 
invoked Seminole Rock or analogous precedent (such as Auer or Thomas Jefferson) as the deference test; in other words, Seminole Rock was employed in a mere $7.1 \%$ of eligible cases. Why has the invocation of Seminole Rock been so sporadic?

One partial explanation is that the Court was more likely to invoke the deference regime when it was prepared to uphold the agency's view. The agency win rate for cases where the Court invoked Seminole Rock (or an analogous precedent) was an outstanding $90.9 \%$. This is significantly higher than the win rate for those Seminole Rock-eligible cases where Seminole Rock was not invoked, which was $75.0 \%$ (not unimpressive). A more interesting reason has been suggested by Justice Thomas. Dissenting in Thomas Jefferson, he cautioned that Seminole Rock deference runs the risk of an agency bootstrapping dubious statutory views into law by adopting vague regulations and then construing them. ${ }^{72}$ In this vein, the Court sometimes declines to apply Seminole Rock deference when the agency has changed its interpretation, perhaps suggesting opportunism rather than a law-like deployment of detailed regulations. ${ }^{73}$

A third, and in our view the best, explanation is that Justices authoring opinions upholding agency constructions of their own regulations had other deferential options. As Table 2 indicates, the Court invoked a range of deference regimes when it could have, instead, been invoking Seminole Rock, most notably Consultative Deference (21.3\% of cases), Chevron (20.0\% of cases), and Skidmore (12.3\% of cases). Yet it is notable that, consistent with the overall trend in the dataset, the most common choice made by the Court was to invoke no deference regime at all; in $27.7 \%$ of all cases involving an agency interpretation of its own regulation, the Court used ad hoc judicial reasoning as opposed to a deference test.

72. Thomas Jefferson Univ. v. Shalala, 512 U.S. 504; 525 (1994) (Thomas, J., dissenting); see Christensen v. Harris County, 529 U.S. 576, 587-88 (2000) (Thomas, J.) (declining to apply Auer [Seminole Rock] deference when the regulation itself is clear and only entitled to Skidmore deference); Robert A. Anthony, The Supreme Court and the APA: Sometimes They Just Don't Get It, 10 ADMIN. L.J. AM. U. 1, 4-12 (1996) (arguing that current Supreme Court deference toward agency interpretations goes against the spirit of the Administrative Procedure Act (APA) by allowing agencies effectively to create their own law); John F. Manning, Constitutional Structure and Judicial Deference to Agency Interpretation of Agency Rules, 96 CoLuM. L. REv. 612 (1996) (arguing that current Supreme Court deference toward agency interpretations, which allows the agencies to create their own law, raises a separation of powers problem).

73. For cases where the Court explicitly declined to accord Seminole Rock deference because the agency "interpretation" had changed, see Norfolk Southern Railway Co. v. Shanklin, 529 U.S. 344,356 (2000); Comm'r v. Schleier, 515 U.S. 323, 334 n.7 (1995); Bowen v. Georgetown Univ. Hosp., 488 U.S. 204, 212-13 (1988); and Huffman v. Western Nuclear, Inc., 486 U.S. 663, 673 n.9 (1988). In Gonzales v. Oregon, the Court rejected the government's argument that the Ashcroft Directive was entitled to Seminole Rock deference on the odd ground that the regulation simply "parroted" the statute. 549 U.S. 243, 256-61 (2006); $c f$. id. at 277-81 (Scalia, J., dissenting) (wittily critiquing the majority's "antiparroting canon"). A stronger ground for rejection would have been that because Attorney General Ashcroft's interpretation was adopted thirty years after the regulation in question and had been previously considered and rejected, Seminole Rock was not appropriate to apply. 


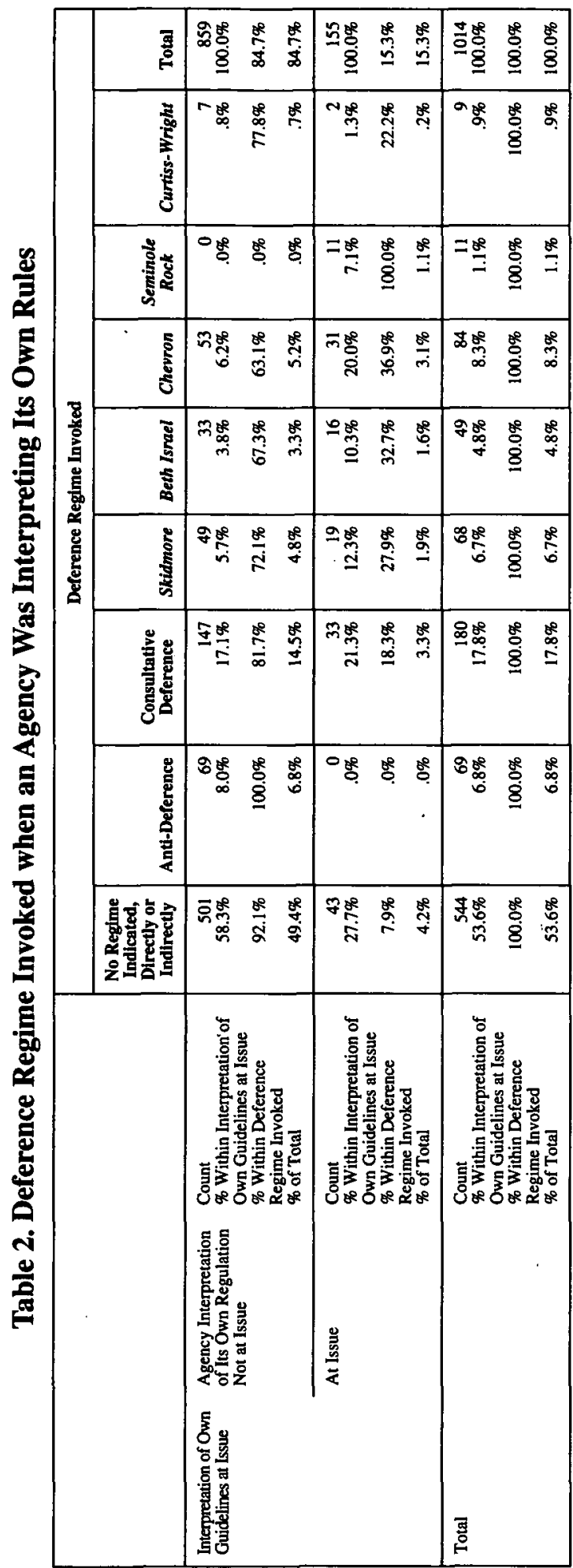




\section{Beth Israel Deference for Agency Elaborations of Statutory Schemes}

Prior to Chevron, the Court had articulated numerous agency-specific deference regimes that in form and substance foreshadowed the Chevron test. Invocation of these cases, which resemble and presage Chevron's reasonability review of agency interpretations when statutes are ambiguous, has continued during the Chevron era.

Consider an example. Settling a strike by its union, Auciello Iron Works agreed to a new collective bargaining agreement. Right after the workers returned to their jobs, however, Auciello renounced the agreement on the ground that it reasonably believed that the union no longer represented a majority of the workers. Although this action violated no specific provision of the National Labor Relations Act (NLRA), the National Labor Relations Board (NLRB) ruled that Auciello's disavowal was an unfair labor practice because it violated the Board's long-established precedents regulating employer contractdisavowals and undermined the Act's policy of encouraging labor stability and peace. ${ }^{74}$ The Supreme Court affirmed the Board's interpretation in 1996-more than a decade and dozens of law review articles after the "Chevron Revolution."75 Although the Court has sometimes invoked Chevron deference for NLRB orders, it did not do so in Auciello Iron Works, Inc. v. NLRB. Nor did it apply Chevron's distinctive two-step formula. Instead, the Court briefly noted the "considerable deference" it has long accorded the Board's judgments pursuant to "its charge to develop national labor policy." "Its primary citation was to Beth Israel Hospital v. NLRB. ${ }^{77}$

At issue in Beth Israel was the NLRB's interpretation of the 1974 health field amendments to the NLRA. In affirming the Board's interpretation, the Court opined that "[e]ven if the legislative history arguably pointed toward a contrary view, the Board's construction of the statute's policies would be entitled to considerable deference." narrow," and that "[t]he rule which the Board adopts is judicially reviewable for consistency with the Act, and for rationality." 79 Notice the rhetorical similarities not only between Beth Israel and Chevron, but also between Beth Israel and

74. Auciello Iron Works, Inc., 317 N.L.R.B. 364 (1995). There was a technical issue not settled by the Board's precedents, namely, whether Auciello lost the ability to disavow because it had all the facts concerning union membership at hand before it signed the contract. The Board ruled that that conduct was in bad faith.

75. Auciello Iron Works, Inc. v. NLRB, 517 U.S. 781 (1996).

76. Id. at 787-88.

77. See, e.g., id. at 788 (citing Beth Israel Hosp. v. NLRB, 437 U.S. 483, 500-01 (1978)). The Auciello Court also invoked NLRB v. Curtin Matheson Scientific, Inc., 494 U.S. 775 (1990), another NLRB deference case which ignored Chevron and relied on NLRB v. J. Weingarten, Inc., 420 U.S. 251 (1975), another pre-Chevron NLRB deference case similar to Beth Israel.

78. Beth Israel, 437 U.S. at 500 (citing Weingarten, 420 U.S. at 266-67; NLRB v. Iron Workers, 434 U.S. 335, $350(1978)$ ).

79. Id. at 501 (emphasis added); accord Weingarten, 420 U.S. at 265-66 (deference even when Board is changing interpretations). 
other Supreme Court deference opinions in the $1970 \mathrm{~s} .{ }^{80} \mathrm{We}$, therefore, use the term Beth Israel deference to represent the continuing invocation of all of these tests that precede and anticipate Chevron.

The conceptual basis for deference in these pre-Chevron cases is a blend of formal and functional themes. That is, Congress has given an agency responsibility (and sometimes lawmaking authority) to fill in the "interstices" of a statutory scheme that the statute lays out in general terms. ${ }^{81}$ "That delegation helps ensure that in 'this area of limitless factual variations,' like cases will be treated alike. It also helps guarantee that the rules will be written by 'masters of the subject,' who will be responsible for putting the rules into effect." 82 To carry out the congressional purpose, the agency needs discretionary breathing room, and so courts should not second-guess their decisions unless inconsistent in some important way with the statute as Congress devised and wrote it. Finally, the agency decisions constitute a body of law that renders the statutory scheme both transparent and predictable to the persons and entities subject to it. ${ }^{83}$

Given the similarities between the deference tests found in Beth Israel-type cases and the Chevron test itself, one would have expected Beth Israel deference to have died in Chevron's wake. Our data show, however, that this has not been the case. In forty-nine post-Chevron cases, the Court invoked Beth Israel deference and refrained from mentioning Chevron, any of the post-Chevron cases, or the famous two-step formula. Further, the application of Beth Israel deference is found not only in labor law (the area in which the Beth Israel decision was grounded), ${ }^{84}$ but also in immigration, ${ }^{85}$ treaty interpretation, ${ }^{86}$

80. See, e.g., Batterton v. Francis, 432 U.S. 416, 425 (1977) (when Congress delegates lawmaking authority to an agency, that agency, and not the courts, has "primary responsibility" for interpreting the statute, and the "reviewing court is not free to set aside [agency] regulations simply because it would have interpreted the statute in a different manner"); see also Nat'l Muffler Dealers Ass'n v. United States, 440 U.S. 472 (1979). The Court in National Muffler deferred to a Treasury Department interpretation of the charitable contribution provision of the tax code. When the relevant statutory term is undefined or unclear, "this Court customarily defers to the regulation, which, if found to "implement the congressional mandate in some reasonable manner," must be upheld."' Id. at 476 (quoting United States v. Cartwright, 411 U.S. 546, 550 (1973), in turn quoting United States v. Correll, 389 U.S. 299, 307 (1967)).

81. See Beth Israel, 437 U.S. at 500-01; accord Nat'l Muffler, 440 U.S. at 477.

82. Nat'l Muffler, 440 U.S. at 477 (quoting Correll, 389 U.S. at 307; United States v. Moore, 95 U.S. 760,763 (1878)) (internal citations omitted).

83. See Duro v. Reina, 495 U.S. 676, 691-92 (1990) (deferring to Solicitor of Department of the Interior opinions for this reason).

84. See, e.g., Auciello Iron Works, Inc. v. NLRB, 517 U.S. 781, 787-88 (1996) (applying Beth Israel deference).

85. See, e.g., Reno v. Flores, 507 U.S. 292, 309, 312 n.8 (1993) (invoking the "reasonable foundation" deference rule of Carlson v. Landon, 342 U.S. 524 (1952)); INS v. Doherty, 502 U.S. 314 , 323 (1992) (respecting Attorney General's "broad discretion" whether to re-open immigration proceedings (quoting INS v. Rios-Pineda, 471 U.S. 444, 449(1985))).

86. See, e.g., Sanchez-Llamas v. Oregon, 126 S.Ct. 2669 (2006) (following Kolovrat v. Oregon, 366 U.S. 187, 194 (1961), which accords "great weight" to executive branch treaty interpretations); El Al Israel Airlines, Ltd. v. Tsui Yuan Tseng, 525 U.S. 155, 168 (1999) (applying similar deferential approach of Sumitomo Shoji Am., Inc. v. Avagliano, 457 U.S. 176, 184-85 (1982)). 
sentencing, ${ }^{87}$ education, ${ }^{88}$ and regulated industries. ${ }^{89}$

In $75.5 \%$ of the Beth Israel cases, the agency was acting pursuant to delegated lawmaking authority, and so invocation or at least mention of Chevron would have been appropriate. Why did the Court not follow or even mention Chevron? One possible answer is that Beth Israel deference died a slow death, gradually petering out after Chevron instead of ceasing immediately. This theory holds that Beth Israel deference might have continued to exist into the 1980s, but that once Chevron became established as the meta-test, the Justices would cite to it if they cited anything. Auciello Iron Works, of course, is a counter-example, and our data demonstrate that Auciello was not an aberration. More than half $(51.0 \%)$ of the Beth Israel cases came after January 1, 1990, when Chevron had clearly become the prevailing approach.

Another theory is that because the Beth Israel deference tests are analogous to Chevron's two-step test, and in one case virtually identical, ${ }^{90}$ some Justices (or their law clerks) have considered them interchangeable as a matter of citation. While Chevron is the more recognizable test, it is also more controversial and sometimes polarizing. It is possible that some Justices (or their clerks) cite pre-Chevron regimes in order to avoid a messy debate as to the "meaning" of Chevron, which remains a source of sharp debate among the Justices.

Perhaps the most likely reason is that specialized practices-such as labor, immigration, treaty interpretation, and criminal sentencing-prefer their particular deference precedents and continue to cite them, often leading the Court to follow suit. The best example of this phenomenon is tax (always a special case, concededly). There is a long-standing consensus among the tax bar that the Internal Revenue Code's general delegation of authority to the Internal Revenue Service (section 7805) is not a general lawmaking delegation, in contrast to the many particular delegations. ${ }^{91}$ Hence, the Court rarely applies Chevron to IRS interpretations. If a deference regime is applied, it is usually the pre-Chevron

87. See, e.g., Edwards v. United States, 523 U.S. 511 (1998); United States v. LaBonte, 520 U.S. 751,757 (1997) (dodging the Chevron issue and giving general deference to the Commission); Melendez v. United States, 518 U.S. 120, 129-30 (1996) (applying an unspecified but deferential mode of review to the Sentencing Commission's interpretation of its Guidelines); United States v. Dunnigan, 507 U.S. 87 (1993).

88. See, e.g., Honig v. Doe, 484 U.S. 305, 326 (1988) (adopting an approach of deference toward Department of Education's interpretations of relevant statute because it is the "agency charged with monitoring and enforcing the statute" (citing INS v. Cardoza-Fonseca, 480 U.S. 421, 448 (1987)).

89. See, e.g., New York v. Fed. Energy Regulatory Comm'n [FERC], 535 U.S. 1, 28 (2002) (energy); Basic Inc. v. Levinson, 485 U.S. 224 (1988) (securities); City of New York v. Fed. Commc'ns Comm'n [FCC], 486 U.S. 57, $64-67$ (1988) (communications).

90. Batterton v. Francis, 432 U.S. 416, 425 (1977) (when Congress delegates lawmaking authority to an agency, that agency and not the courts has "primary responsibility" for interpreting the statute, and the "reviewing court is not free to set aside [agency] regulations simply because it would have interpreted the statute in a different manner").

91. See, e.g., Ellen P. Aprill, Muffled Chevron: Judicial Review of Tax Regulations, 3 Fla. TAX REv. 51, 56-57 (1996); Linda Galler, Emerging Standards for Judicial Review of IRS Revenue Rulings, 72 B.U. L. REv. 841,849 \& n.53 (1992). 
regime associated with National Muffler Dealers v. United States. ${ }^{92}$ The Court in National Muffler ruled that IRS regulations developed under its general rulemaking authority are entitled to deferential consideration, but not as much as rules developed under one of the specific grants of rulemaking authority. ${ }^{93}$

\section{Skidmore Deference for Expert Agency Judgments}

Under the Skidmore standard of deference, an agency interpretation is entitled to "respect proportional to its power to persuade," with such power determined by the interpretation's "thoroughness, logic and expertness"; its "fit with prior interpretations"; and "any other sources of weight" the court chooses to consider. ${ }^{94}$ This standard of review is not as generous to the agency as Chevron's reasonability standard, and it places potentially more discretion in the hands of judges. Indeed, according to Justice Scalia's Mead dissent, the Chevron Revolution rendered Skidmore obsolete. ${ }^{95}$ The Mead majority, however, pronounced Skidmore alive and well, holding that the Court limited Chevron deference to those instances when there was a congressional delegation of lawmaking authority to the agency, and maintaining that when Congress has not delegated lawmaking authority to the agency, Skidmore deference governs. ${ }^{96}$

Our data both confirm and question Mead's position on Skidmore. On the one hand, it is correct that Skidmore was still an important part of the Court's deference jurisprudence when Mead was decided..$^{97}$ By our count, the Court had invoked the Skidmore deference regime fifty-four times between the Chevron decision and the Mead decision.

Many of these decisions were headline-grabbing interpretations of landmark statutes. For example, the Court handed down an important interpretation of the Americans with Disabilities Act (ADA) in Bragdon v. Abbott..$^{98}$ The issue was whether HIV infection or non-symptomatic AIDS was a "disability" covered by the public accommodations title, which concededly applied to the defendant's

92. 440 U.S. 472 (1979). The leading case is Cottage Savings Ass'n v. Comm'r, 499 U.S. 554 (1991), following the deference regime of National Muffler Dealers. Id. at 560-61. See also United States v. Cleveland Indians Baseball Co., 532 U.S. 200, 219(2001) (also following Muffler). Cottage Savings has, in turn, been followed and applied in Boeing Co. v. United States, 537 U.S. 437,448 (2003) and Atlantic Mutual Ins. Co. v. Comm'r, 523 U.S. 382 (1998).

93. Nat'l Muffler, 440 U.S. at 476; accord United States v. Vogel Fertilizer Co., 455 U.S. 16, 24 (1982).

94. Skidmore v. Swift \& Co., 323 U.S. 134, 140 (1944), followed and quoted in United States v. Mead Corp., 533 U.S. 218, 235 (2001); see Hickman \& Krueger, supra note 32, at 1281-91 (engaging in a thorough examination of the Skidmore factors, as expanded in Mead and applied post-Mead by the courts of appeals).

95. Mead, 533 U.S. at 241, 250 (Scalia, J., dissenting).

96. The rationale for permitting Skidmore deference when there has not been a congressional delegation of lawmaking authority is grounded in agencies' expertise, broad investigative powers, and understanding of national issues and also in a desire to create uniformity in administration. Id. at 234 (majority opinion).

97. For empirical evidence that Skidmore remains an important deference approach among the courts of appeals, see Hickman \& Krueger, supra note 32, at 1259-81.

98. 524 U.S. 624 (1998). 
dental practice. The claimant, Sidney Abbott, relied on regulations adopted by several federal agencies applying the Rehabilitation Act's AIDS-inclusive understanding to the ADA. Justice Kennedy's opinion for a closely divided Court invoked these opinions as "confirmation" of the medical evidence that HIVinfection is a disability as the ADA defines the term. He invoked Chevron deference for the view of the Department of Justice (with delegated authority to interpret that part of the ADA) ${ }^{99}$ and Skidmore deference for the views of other federal agencies under both the Rehabilitation Act and the ADA. ${ }^{100}$ The unanimity of the agency views, Congress's awareness of them when it enacted the ADA, and their grounding in medical understandings gave the agency views unusually powerful cogency under Skidmore and justified Justice Kennedy's unwillingness to rest upon Chevron alone. ${ }^{101}$

On the other hand, the Court's own post-Mead jurisprudence has not followed the rules laid down by the Mead decision. The Court relied on Skidmore fourteen times in the 203 cases between Mead and Hamdan; in other words, in the post-Mead era, the Court invoked Skidmore in $6.9 \%$ of its cases involving agency interpretations of federal statutes. This rate of invocation is nearly identical to the rate at which Skidmore was invoked in the pre-Mead era, $6.7 \%$. On first glance, this data would seem to support Mead, if that case was taken to stand merely for the proposition that Skidmore was, and would continue to be, a part of the Court's deference jurisprudence. Yet Mead did more than that; it claimed to establish a formula for delineating between Skidmore's and Chevron's domains, with the latter case governing when there had been a congressional delegation of lawmaking authority to the agency and the former governing when there had not. When one examines whether this formula has been complied with, one finds that Mead's directives have not been played out in a predictable manner.

In the pre-Mead era, there was a congressional delegation of lawmaking authority to the agency in 33.3\% of the Skidmore cases, but in the post-Mead era the fraction of Skidmore cases involving a congressional delegation of lawmaking authority skyrocketed to $57.1 \%$. Presumably, had the Mead formula been followed, the opposite would have occurred. Even more troubling is that the percentage of Skidmore cases involving formal congressional delegations (strictly defined) jumped from $20.4 \%$ in the pre-Mead era to $42.9 \%$ in the post-Mead era. In other words, not only has post-Mead Skidmore deference been more heavily tilted towards cases where there has been a congressional delegation of lawmaking authority, it has been tilted towards those cases where this delegation is of the most formal sort-that is, the sort easiest to parcel off to Chevron under Mead. Moreover, the problem is not just that cases where there

99. Id. at 646.

100. Id. at $642-45$ (pre-ADA agency interpretation of the Rehabilitation Act to include HIVinfection); id. at 647 (agency interpretations of the ADA).

101. See id. at 642 . 
has been a congressional delegation of lawmaking authority are making up an ever larger percentage of Skidmore cases, but that Skidmore deference is being invoked in an ever larger percentage of those cases where there has been a congressional delegation of lawmaking authority-15.4\% of such cases post$M e a d$, as opposed to $8.4 \%$ in the pre-Mead era.

Here, contrasting Skidmore cases post-Mead with Chevron cases post-Mead is instructive. After $\mathrm{Mead}$, the percentage of Chevron cases involving a congressional delegation of lawmaking authority increased slightly, from $88.7 \%$ preMead, to $92.3 \%$ post-Mead. Yet, during that same period, the frequency with which Chevron was invoked in cases involving a congressional delegation of lawmaking authority fell from $29.3 \%$ to $23.1 \%$. In other words, while the internal composition of Chevron cases started to change in line with the Mead directive, overall the Court's deference jurisprudence moved in the opposite direction. Given the data above, we can certainly attribute some of this movement to the Court's practice of applying Skidmore, which has run contrary to Mead in some striking ways.

\section{Consultative Deference for Agency Inputs Where the Court Does Not} Announce a Deference Regime

To this point, we have discussed deference regimes grounded in particular standards of deference, such as the "respect proportional to its power to persuade" standard in Skidmore or the "controlling unless plainly erroneous or inconsistent with the regulation" standard in Seminole Rock. It follows that cases fall under these deference regimes when they explicitly invoke the relevant deference standard. In a large number of cases, however, the Supreme Court does not invoke a specific standard of deference-it does not name or seem to follow one of the regimes we have mentioned-yet it appears that the Court is expressing a deferential attitude. In these cases, the Court relies on some input from the agency -an amicus brief, a manual, an interpretive rule, or the like-to shape its reasoning and influence its decision. But it does so without explicitly stating that it is deferring to the agency, and without invoking any standard by which these inputs are weighed. It is this category of cases that we refer to as involving a regime of consultative deference.

For example, in Hamdan, the Military Commissions Case, the Court declined to follow Justice Thomas's invocation of Curtiss-Wright deference, but did not treat the President's judgment as irrelevant to the issue whether the procedures mandated for those commissions violated the Uniform Code of Military Justice (UCMJ). Section 836(a) of the UCMJ authorized the President to issue regulations which, "so far as he considers practicable," comport with process accorded defendants in criminal cases; section 836(b) required that procedures in courts martial and military commissions be "uniform," again "insofar as practi- 
cable." ${ }^{102}$ The Court stated that it would accord "deference" to the President's judgment as to practicability, but found that the President had reached no public judgment as to the section 836 (b) uniformity requirement. ${ }^{103}$ There was also indication in Justice Stevens's opinion that the Court majority was very attentive to the President's precise arguments. In rejecting some of the arguments made by Justice Thomas, Justice Stevens relied on the President's failure to make the Thomas arguments. ${ }^{104}$ This last point was not enough (standing alone) to justify coding Hamdan as a consultative deference case, but it confirmed our inclination to code it as such based on the explicit statement that deference of some sort was owed.

Foreign affairs and national security are far from the only areas where the Court gives what we are calling consultative deference to agency inputs. In antitrust law, the Court is often moved by the Department of Justice (DOJ)/ Federal Trade Commission (FTC) Guidelines, ${ }^{105}$ and has followed agency leads in recent cases that have overruled longstanding interpretations of the Sherman Act. ${ }^{106}$ In the civil rights area, the Equal Employment Opportunity Commission (EEOC) and the Department of Education sometimes influence the Court with their interpretive guidances; we coded these cases as consultative deference when there was no citation to Skidmore or a Skidmore case. ${ }^{107}$

The Court also applies what we are calling consultative deference when it clearly relies on amicus briefs filed by the Solicitor General as quasiauthoritative on points of fact or even law. ${ }^{108}$ These briefs are the product of work by the Solicitor General's brainy young associates and inputs from the relevant agencies. To be sure, agency attorneys bitterly complain that the Solicitor General does not always represent their perspectives as their own counsel would and sometimes even marginalizes them. But that may be a "plus" from the Court's point of view. The Justices understand that the Solicitor General is providing agency-based inputs that no one else is providing, while at the same time remaining free from the agency's sometimes blindered (or captured) point of view. It is perhaps for this reason that the Court often requests that the Solicitor General submit an amicus brief.

102. 10 U.S.C. $\S 836$ (a)-(b). Even though the statute explicitly authorized the President to issue procedural regulations, neither the Court nor Justice Thomas even mentioned Chevron as a possible deference regime. This strikes us as anomalous.

103. Hamdan v. Rumsfeld, 126 S. Ct. 2749, 2791 \& n.51 (2006) (Stevens, J., for the Court); id. at 2811 (Kennedy, J., concurring in part).

104. See id. at 2778 n.31, 2779 n.32 (Stevens, J., for the Court).

105. See, e.g., Texaco, Inc. v. Dagher, 547 U.S. 1 (2006).

106. See, e.g., Leegin Creative Leather Prods. v. PSKS, Inc., 127 S. Ct. 2705, 2721 (2007) (overruling Dr. Miles Med. Co. v. John D. Park \& Sons Co., 220 U.S. 373 (1911), and closely following the reasoning suggested by the Department of Justice's amicus brief).

107. See, e.g., Jackson v. Birmingham Bd. of Educ., 544 U.S. 167, 179 (2005); Penn. State Police v. Suders, 542 U.S. 129, 142-43 (2004); Burlington Indus., Inc. v. Ellerth, 524 U.S. 742,764 (1998); Faragher v. City of Boca Raton, 524 U.S. 775, 799-800, 806, 809 (1998).

108. In 314 cases, the "agency" interpretation of the statute was presented only in the Solicitor General's amicus brief. 
In bankruptcy cases, there is no agency to which the Court can defer; there is no Bankruptcy Commission. Yet the Court often requests amicus briefs from the Solicitor General in bankruptcy cases. The attorneys who work on bankruptcy cases for the Solicitor General come to know their subject matter more deeply than the Justices could be expected to, consulting bankruptcy experts and drawing on the resources of the office of the United States Trustee, located in the Department of Justice. ${ }^{109}$ The analysis in these briefs often influences the Court's judgment in ways that resemble Skidmore deference. In Associates Commercial Corp. v. Rash, ${ }^{110}$ for example, the Court cited, relied on, and closely followed the Solicitor General's analysis of how to value property retained by a debtor in bankruptcy and not turned over to secured creditors. The Court rejected not only the valuation approach of the lower court under review, but also a compromise approach followed by the respected Second and Seventh Circuits. ${ }^{111}$ The words of the statute ultimately answered the interpretive issue but only after they were understood in the context of bankruptcy policy. For both textual and policy analyses, the Solicitor General's amicus brief proved dispositive. It is not uncommon for the Court's bankruptcy opinions to closely follow the analysis of Solicitor General amicus briefs, as it did in Rash. ${ }^{112}$

Unlike bankruptcy, federal pension law (the Employment Retirement Income Security Act, or ERISA ${ }^{113}$ ) is not only overseen by an agency, but by two agencies: the Department of Labor and the Internal Revenue Service, both of which have promulgated regulations. The regulations answer few of the litigated ERISA issues, especially preemption issues that have dominated the Court's ERISA docket. Hence, the Court regularly solicits the Solicitor General's views and almost as regularly relies on those amicus briefs for facts and predictions, policy analysis, and legal materials. ${ }^{114}$ Amicus briefs filed by the Solicitor General are particularly influential in other areas of law as well, particularly technical areas such as patents, transportation, and communications.

Even though it is not an officially named and recognized deference category, consultative deference is by far the most frequent deference regime actually followed by the Court. These cases constitute $17.8 \%$ of all cases where an agency interpretation of a statute was at issue. They are eclipsed only by the

109. Charged with representing the interests of the United States (often a creditor in bankruptcy), the Trustee collects and analyzes bankruptcy filings and adjudications. As the top official, the Trustee is quite knowledgeable about the policy as well as legal issues. Our generalizations about the Solicitor General's handling of bankruptcy cases comes from conversations with leading appellate counsel in bankruptcy cases.

110. 520 U.S. 953 (1997).

111. The majority and concurring opinions in In re Hoskins, 102 F.3d 311 (7th Cir. 1996), are particularly illuminating analyses of bankruptcy policy. See Rash, 520 U.S. at 966-67 (Stevens, J., dissenting).

112. See, e.g., Lamie v. United States Trustee, 540 U.S. 526 (2004); Till v. SCS Credit Corp., 541 U.S. 465 (2004); Dewsnup v. Timm, 502 U.S. 410, 417 (1992).

113. Pub. L. No. 93-406, 88 Stat. 829 (1974) (codified in scattered sections of 29 U.S.C. and the Internal Revenue Code).

114. See, e.g., Varity Corp. v. Howe, 516 U.S. 489 (1996). 
category of cases in which no deference regime is invoked at all. It is worth considering why this might be the case.

It is not difficult to see why the Court would rely on agency inputs in its reasoning and decisionmaking. The agency typically provides the Court with useful information-including the legislative history and background of the statute; pertinent regulatory history and notation of agency actions that might be relevant; data and facts relating to the regulatory regime and the issue before the Court; and experience-based analysis of how different interpretations fit with the purpose and evolution of the statutory scheme. This information is often not found in other legal sources or briefs. Additionally, agency inputs are normative focal points that exercise a kind of gravitational pull for issues on which the Justices have no strong opinion. In Rash, Justice Ginsburg and her colleagues probably felt bewildered by the array of well-reasoned but conflicting circuit court decisions on the valuation issue. The Solicitor General's view was sensible enough, but its chief virtue was that it settled an issue vexing the lower courts and was tendered by attorneys the Court trusted to be judicious. ${ }^{115}$ The agency input provided a basis for decision that the Court, reasoning on its own, would not have had.

Still, even if it is easy to see why the Court would rely on agency inputs in its reasoning and decisionmaking, it is not obvious why the Court would do so without invoking any of the applicable deference standards the other regimes provide. Why suggest the persuasiveness of a brief by citing it, when Skidmore could be invoked as a basis for relying on briefs that are persuasive? Why credit an agency's interpretation of its own regulation without citing Seminole Rock? These are vexing questions our data cannot answer. The reasons are probably practical as well as doctrinal. In the bankruptcy cases, for just one area, there is no single agency to which Congress has delegated authority. In other cases, such as ERISA, there are two agencies, and the Court may find it convenient simply to draw from an amicus brief rather than announce that it is following Skidmore or another deference regime. Justice Ginsburg and perhaps others may prefer as a matter of style to incorporate agency reasoning into their opinions rather than to announce a formal deference test-especially if such an announcement would trigger a special concurring opinion or become a target for dissenters. Sometimes, Justices may not even notice how much their clerk-drafted opinions draw from and rely on government submissions in a manner strikingly similar to what Skidmore advocates. Justice Scalia believes that Skidmore is invalid, and so he would not cite it for that reason.

It is possible that Justices sometimes assume that their reasoning so closely adheres to the standard set out by a particular deference regime that there is no

115. We add this important qualification: The United States does have a bias, for it is often a creditor in bankruptcy. Hence, it may be no coincidence that its valuation rule in Rash was the most pro-creditor rule, and one that no less a staunch capitalist as Frank Easterbrook maintains will grant a windfall to undersecured creditors (like banks) at the expense of unsecured creditors (like small businesses and personal creditors). Hoskins, 102 F.3d at 320 (Easterbrook, J., concurring). 
need to cite the regime itself. This inverts the questions above: Why cite Skidmore when it is clear you are giving agency inputs "respect proportional to [their] power to persuade"? ${ }^{116}$ Why cite Seminole Rock when you are giving credit to an agency interpretation of its own regulations that is not "erroneous or inconsistent with the regulation"? ${ }^{117}$ The standard answer would be that the role of precedent in the Court's decisionmaking process requires that the Court constantly, and explicitly, re-indicate which decision rules it considers alive and well. The Court's practice, however, seems to indicate that the Justices do not find this necessary.

Regardless of the reasons for the Court's practice, which we explore further below, it is clear that the consultative deference category sheds new light on how the Court defers. Our study demonstrates that deference without the invocation of a named deference regime is a commonly used method of decisionmaking —one more common, in fact, than any named deference regime.

\section{Anti-Deference}

To this point, we have described deference regimes under which the agency interpretation is afforded some presumption of correctness. However, antideference (that is, a presumption running against agency interpretations) also has a place in the Court's practice. Anti-deference, as invoked by the Court, has several interconnected threads, all illustrated or suggested in Gonzales v. Oregon. ${ }^{118}$ The most obvious is the rule of lenity, which requires that ambiguous statutes be construed in favor of criminal defendants. ${ }^{119}$ A related doctrine is the avoidance canon, the presumption or rule that, when a statute is ambiguous and one interpretation would present serious constitutional difficulties, the Court should avoid those difficulties by choosing the clearly constitutional alternative interpretation. ${ }^{120}$ While cases invoking the rule of lenity can usually be considered to be invoking a regime of anti-deference, ${ }^{121}$ cases invoking the avoidance

116. United States v. Mead, 533 U.S. 218, 235 (2001) (quoting Skidmore v. Swift \& Co., 323 U.S. 134,140 (1944)) (internal quotation marks omitted).

117. Bowles v. Seminole Rock \& Sand Co., 325 U.S. 410, 414 (1945).

118. 546 U.S. 243 (2006).

119. Id. at 263-64 (expressing reluctance to read the law to vest discretion in the Department of Justice to expand criminal liability). For lucid explications of the rule of lenity and strong support for it, see, for example, United States v. Aguilar, 515 U.S. 593 (1995) and United States v. Granderson, 511 U.S. 39 (1994).

120. Oregon, 546 U.S. at $268-69$ (expressing reluctance to vest the Department of Justice with discretion to apply the statute in the teeth of constitutional problems with denying any and all aid-in-dying). On the avoidance canon, see generally NLRB v. Catholic Bishop of Chicago, 440 U.S. 490 (1979); John Copeland Nagle, Delaware \& Hudson Revisited, 72 Notre DaME L. Rev. 1495 (1997); Adrian Vermeule, Saving Constructions, 85 GEO. L.J. 1945 (1997).

121. In matters of substantive criminal law, the agency is almost always aligned against the criminal defendant; the rare exceptions are when the Solicitor General confesses error at the Supreme Court level. In matters of criminal sentencing, however, the agency (the Sentencing Commission, not the Department of Justice) is often on the side of the criminal defendant. See, e.g., Neal v. United States, 516 U.S. 284 (1996). 
canon can only be considered to be invoking a regime of anti-deference when the canon is used to provide a presumption against the agency, as in Oregon. ${ }^{122}$

Also illustrating the anti-deference regime is McNally v. United States. ${ }^{123}$ The federal mail fraud statute makes it a crime to use the mails for the purpose of executing "any scheme or artifice to defraud." ${ }^{24}$ The government prosecuted several state officials and a private associate for creating a kickback scheme from firms doing business with the state. Although the lower courts had applied the statute to include such conduct as a "scheme to defraud," the Supreme Court construed it more narrowly to cover only those fraudulent schemes depriving the public of tangible losses (therefore, not just loss of good government). ${ }^{125}$ Justice White's opinion for the Court concluded:

Rather than construe the statute in a manner that leaves its outer boundaries ambiguous and involves the Federal Government in setting standards of disclosure and good government for local and state officials, we read [the mail fraud law] as limited in scope to the protection of property rights. If Congress desires to go further, it must speak more clearly than it has. ${ }^{126}$

In reaching this conclusion, he invoked both the rule of lenity and the avoidance canon.

McNally was by no means a rare case. In $6.8 \%$ of the cases we coded (sixty-nine cases, in absolute terms), the Court invoked an anti-deference regime. This is slightly more than three-quarters the number of cases in which Chevron was invoked (eighty-four) and about the same number in which Skidmore was invoked. It is more than six times as many cases as mentioned Seminole Rock (eleven). The percentage of cases that invoke anti-deference seems even more significant when one is reminded that the Court in the overwhelming majority of cases opts to invoke no deference regime at all.

Predictably, the anti-deference cases present a much lower win rate for the agency than any other deference regime. In anti-deference cases, the agency wins only $36.2 \%$ of the time. Yet it is questionable whether invocation of an anti-deference regime leads to outcomes that disfavor the agency or whether the Court is simply more wont to invoke the anti-deference regime when it is already inclined to rule against the agency. Our data support the latter hypothesis. In theory, the anti-deference regime can be invoked in all criminal cases. In practice, however, the Court only invoked the anti-deference regime in $32.5 \%$ of criminal cases (37 of 114). The win rate for those criminal cases where

122. In our coding schema, we did not code cases as "anti-deference" if the constitutional problem did not cut against the agency interpretation or if the Court did not mention the rule of lenity or the avoidance canon.

123. 483 U.S. 350 (1987).

124. See 18 U.S.C. $\$ 1341$ (2000 \& Supp. 2005).

125. McNally, 483 U.S. at 360-61.

126. Id. at 360 . 
Table 3. Anti-Deference and Agency Win Rates in Criminal Cases

\begin{tabular}{|l|c|c|}
\hline & $\begin{array}{c}\text { Percentage of } \\
\text { Cases in } \\
\text { Population }\end{array}$ & $\begin{array}{c}\text { Agency Win } \\
\text { Rate }\end{array}$ \\
\hline Non-Criminal Cases & $88.8 \%(900)$ & $69.6 \%$ \\
\hline Criminal Cases & $11.2 \%(114)$ & $62.2 \%$ \\
\hline $\begin{array}{l}\text { Criminal Cases in Which } \\
\text { Anti-Deference Is Invoked }\end{array}$ & $3.6 \%(37)$ & $37.8 \%$ \\
\hline $\begin{array}{l}\text { Criminal Cases in Which } \\
\text { Anti-Deference Is Not Invoked }\end{array}$ & $7.6 \%(77)$ & $74.0 \%$ \\
\hline
\end{tabular}

anti-deference was invoked was $37.8 \%$ (about the same as the overall win rate for anti-deference cases), but the win rate for those criminal cases where anti-deference was not invoked was $74.0 \%$. This vast disparity in win rates between subsets of the criminal cases suggests that the Court invoked antideference when it was especially ready for the agency to lose.

\section{No Deference Regime Invoked}

For us, the most striking finding of our study was that in the majority of all cases-53.6\% of them-the Court invoked no deference regime at all. This finding is especially notable in light of the fact that we searched hard for signs of deference and counted quite liberally (including Supreme Court reliance on amicus briefs, which formed the bulk of our consultative-deference category). This striking finding is also conceptually significant. It is contrary to both the Court's statements about its own deference practice and the academic literature on the topic. Indeed, in a legal culture where the Court and commentators are obsessed with delineating the distinct domain of Chevron, and arguing over whether the Court's jurisprudence has room for Skidmore, the idea that, more often than not, the Court would not invoke a deference regime is highly counterintuitive.

Not surprisingly, the Court's methodology in these no-deference cases matches what has long been the Court's standard methodology for interpreting statutes. Under this "independent judgment of judges" methodology, the Court normally considers statutory text and the whole act; legislative history and statutory purpose; the evolution of the statute through judicial and other precedents; and substantive policy canons when it interprets statutes. The cogency of these various factors will vary from case to case, and their respective weights depend on their relative concreteness. Indeed, while the statute's plain meaning is both the most authoritative and usually the first-analyzed evidence, the Court almost never stops without checking plain meaning intuitions against other contextual evidence (including the whole act, legislative history or purpose, precedent, and canons of statutory construction). This pragmatic, multi-factored methodology 
is what we have elsewhere called the "funnel of abstraction" approach to statutory interpretation, ${ }^{127}$ and our data provide strong empirical support for the fact that this ad hoc method of statutory interpretation exists and thrives in the administrative realm.

A typical no-deference case is PGA Tour, Inc. v. Martin. ${ }^{128}$ The Americans with Disabilities Act of 1990 (ADA) bars disability-based discrimination by "public accommodations," which the statute defines broadly. ${ }^{129}$ Casey Martin was a professional golfer whose degenerative circulatory disorder required him to use a golf cart in order to compete in tournaments. The PGA's no-cart rule prevented Martin from competing, and the Association declined to waive its rule. The Supreme Court ruled that the ADA required the PGA to accommodate Martin. ${ }^{130}$ The PGA's main argument was that the ADA's anti-discrimination rule is, by its terms, not applicable if accommodating the disabled person "would fundamentally alter the nature" of the PGA's services, namely, the game of highly competitive golf. ${ }^{131}$ Writing for the Court, Justice Stevens (an avid golfer) rejected that interpretation. His opinion relied on the statutory language, as applied by the trial court after extensive testimony about the nature of the game; ${ }^{132}$ the purpose and structure of the ADA, which broadly sought to abolish disability-based discriminations and created careful exceptions for religious, but not athletic institutions, where Congress felt there should be a blanket allowance; ${ }^{133}$ and Congress's specific intent, previously recognized by Supreme Court precedent, to impose an individualized inquiry and not allow blanket rules such as the PGA's. ${ }^{134}$ Although agreeing with the EEOC's bottom line, the Court crafted its own interpretation of the statute's public accommodations provisions, relying on a pragmatic, multi-factored approach to statutory interpretation, rather than deferring to the EEOC's judgment or even mentioning its distinctive factual and legal inputs.

As in the PGA case, the Court's failure to apply a specific deference test to $53.6 \%$ of agency statutory interpretation cases did not mean that the agency fared badly in these cases. In those cases where no deference regime was invoked, the agency won $66.0 \%$ of the time, a figure significantly but -not dramatically lower than the agency win rate in Chevron cases $(76.2 \%)$ and Skidmore cases (73.5\%). The gentle reader might find this result most surprising

127. William N. Eskridge, Jr. \& Philip P. Frickey, Statutory Interpretation, Practical Reasoning, 42 Stan. L. Rev. 321 (1990). For an early empirical test confirming the multi-factored approach we describe, see Nicholas S. Zeppos, The Use of Authority in Statutory Interpretation: An Empirical Analysis, 70 TEx. L. REv. 1073 (1992).

128. 532 U.S. 661 (2001).

129. 42 U.S.C. $\$ 12182$ (a) (2000) (prohibiting discrimination on the basis of disability in public accommodations); id. \$12181(7) (defining "public accommodation").

130. PGA Tour, 532 U.S. at $690-91$.

131. Brief for Petitioner at 8 n.10, PGA Tour, Inc. v. Martin, 532 U.S. 661 (2001) (No. 00-24).

132. PGA Tour, 532 U.S. at 676-88.

133. Id. at 674-76 (legislative history and purpose); id. at $689 \mathrm{n} .51$ (statutory structure).

134. Id. at 688 (citing a committee report and Supreme Court precedent). 
of all, but it is easily explained. Our data are consistent with the conventional wisdom that the Solicitor General's office does an excellent job screening and then arguing cases. ${ }^{135}$ The Solicitor General usually declines to appeal government lower-court losses when the agency interpretation is hard to sustain and sometimes even confesses error when that weakness becomes apparent only after the Court has granted review. ${ }^{136}$ And when the Solicitor General does stick up for an agency interpretation, the office's attorneys write almost uniformly excellent briefs defending it. The conventional wisdom that the Solicitor General's office understands the Court better than any private law firm and, in turn, is trusted by the Justices helps explain why the government wins a large majority of Supreme Court cases even when no formal deference regime is invoked. ${ }^{137}$

Still, it is worth asking why the Court so often opts not to invoke a deference regime, especially given the range of deference regimes available and the Court's strong rhetorical support for them. We offer a few tentative explanations for this silent, but pervasive, reliance on ad hoc judicial reasoning. First, and most important, the Solicitor General in a large minority of cases (including Martin) fails to ask the Court to defer to informal agency interpretations or to the government's views presented in his briefs; without a formal request, the Justices might consider it inappropriate to go out of their way to announce a deference regime. Indeed, the Justices may believe that constant invocation of deference regimes would be inconsistent with the role of an independent judiciary at the heart of Article III. The 1014 cases in our dataset represent a large majority of Supreme Court statutory interpretation cases decided between Chevron and Hamdan. To admit, in case after case, that they are "deferring" to agencies rather than forming their own independent judgments about the law, would announce a greatly diminished judicial role in statutory interpretation. Some Justices may feel that their role as judges, and their responsibility to justly adjudicate cases, trumps the requirements of formal deference tests, even ones they have painstakingly laid out.

One of us thinks it possible that the Court or most of the Justices consider deference tests as a signaling device for lower courts-which handle the vast majority of routine cases of agency interpretation-rather than a binding constraint on their own practice-which is limited to a minute fraction of the most difficult cases. Under this view, the Court may perceive Chevron, Skidmore, and the other formalist deference regimes as guides for lower court judges, which

135. See generally Lincoln CAPLAN, The TENTH Justice (1988).

136. See generally Linda R. Cohen \& Matthew L. Spitzer, The Government Litigant Advantage: Implications for the Law, 28 FLA. ST. U. L. Rev. 391 (2000).

137. It is also possible that there is often a generally deferential attitude among the Justices and their law clerks toward Solicitor General briefs, which may permeate the Court's docket, affecting many of the cases we have coded as "no deference." We have not tried to test or unpack the effects of this generally deferential attitude in this Article. 
are not needed by their most learned (and creative) bench. ${ }^{138}$ The other of us sees little evidence for this proposition but thinks that any jurist would tend to escape from pre-existing deference tests when important issues of national policy present themselves to the Court, as they did in the Military Commissions Case, the Oregon Aid-in-Dying Case, and the Kentucky Kickback Case. ${ }^{139}$

A final hypothesis, and one we both find probably true, is that the Justices and their law clerks (who write the initial drafts of most opinions) wield deference regimes like they wield canons of statutory interpretation-invoked when they align with the outcome the authoring Justice wishes to reach, but jettisoned when they are not useful in reaching that result. Notice that the Court actually invokes Curtiss-Wright, Seminole Rock, and Skidmore in a small minority of cases where those regimes are applicable-and the Court's invocation is strongly correlated with its agreement with or acquiescence in the agency's interpretation. (In the next section, we make the same finding for Chevron.) The converse applies for the rule of lenity even more strongly: the Court rarely mentions it in the large majority of cases, where it agrees with the prosecutors, but frequently mentions it when it is disagreeing.

These explanatory theories are not mutually exclusive, nor are they necessarily exhaustive. The sheer breadth of cases in which the Court invokes no deference regime, and the seemingly unsystematic differentiation between cases where it invokes a deference regime and those where it does not, indicate that multiple, complex factors are likely at play. At this point we are satisfied identifying this anomaly and making an effort at description, fully expecting that better explanation will follow with further study.

\section{B. CHEVRON AS APPLIED (OR NOT) BY THE COURT}

Contrary to the conventional wisdom, Chevron is not the alpha and the omega of Supreme Court agency-deference jurisprudence. Although the "revolutionary" nature of Chevron seems accepted by lawyers, lower court judges, and academics, at the level of Supreme Court practice, and even doctrine, Chevron's status strikes us as something short of that.

First, the Court was highly deferential to agency interpretations before Chevron. ${ }^{140}$ By 1984, the Court had already announced Chevron-like or Chevron-lite deferential approaches in labor law, tax law, treaty interpretation, securities law,

138. Note that proving this hypothesis would require an empirical study of deference at the Court of Appeals level, an object which is beyond the scope of this Article. However, we note that the best recent empirical study of deference among courts of appeals found much lower win rates in Skidmore deference cases $(60.4 \%)$ than we found at the Supreme Court level (73.5\%). Compare Hickman \& Krueger, supra note 32, at 1275-79, with Table 1, supra.

139. Respectively, Hamdan v. Rumsfeld, 126 S. Ct. 2749 (2006); Gonzales v. Oregon, 546 U.S. 243, 259 (2006); and McNally v. United States, 483 U.S. 350 (1987).

140. See Merrill, supra note 40, at 981-84 (1991) (reporting that agency interpretations prevailed at the Supreme Court $75 \%$ of the time in the three years before Chevron, while only $70 \%$ of the time in the six years after Chevron). 
environmental law, and other areas. ${ }^{141}$ Beth Israel and National Muffler sound a lot like Chevron, and at least one other case is an almost perfect fit. Anticipating Mead by a quarter century was the Court's opinion in Batterton v. Francis. ${ }^{142}$ The Court held that when Congress delegates lawmaking authority to an agency (the Department of Health, Education, and Welfare [HEW] in Batterton), "Congress entrusts to the Secretary, rather than to the courts, the primary responsibility for interpreting the statutory term."143 Once the agency has authoritatively construed the statute through legislative rules, the "reviewing court is not free to set aside [agency] regulations simply because it would have interpreted the statute in a different manner." ${ }^{144}$ With cases like Batterton fresh in their minds, it is easy to see why the Justices themselves did not understand their decision in Chevron as revolutionary.

Nor did Chevron sweep the field after 1984. Of the 1014 cases included in our study, Chevron (or a Chevron precedent) was cited in only 120 . In only 84 cases (8.3\% of the population) did the Court apply the Chevron two-step test. Further, as we have seen above, Chevron is but one of an array of deference regimes invoked by the Court. Deference regimes that pre-existed Chevronsuch as Beth Israel and Seminole Rock-continue to thrive. Further, both before and after Mead, the Justices respected and followed Chevron's allegedly obsolete sibling, Skidmore. Likewise, Chevron deference is sometimes sidelined in order to invoke subject-area-specific concerns, like the rule of lenity in criminal cases and super-deference in cases involving foreign affairs. In many other cases, the Court avoids any named deference regime and utilizes what we have called consultative deference. Most important, however, is that the Court in a majority of its agency-interpretation cases (53.6\% of them) applied no deference regime at all. The old "independent judgment of judges" approach that predated the modern administrative state remains the overwhelmingly dominant approach taken by the Justices in cases involving agency inputs. If you add the consultative deference cases, where the Court did not cite or advert to any deference regime, then the no-deference cases would amount to more than $70 \%$ of the 1014 cases in our dataset.

Even if Chevron has not colonized the entire deference landscape as much as some lawyers and experts believe, it may have marked an important shift in judicial attitudes toward agency interpretations. We cast no doubt on the literature finding that lower court judges frequently defer to agencies under Chevron or even Skidmore in the post-Chevron era, perhaps at heightened

141. See supra notes 84-93 and accompanying text.

142. 432 U.S. 416 (1977).

143. Id. at 425 .

144. Id.; see also United States v. O'Hagan, 521 U.S. 642, 673 (1997) (citing both Chevron and Batterton for the proposition in text). 
rates. ${ }^{145}$ Nor do we draw any conclusions from the fact that agency win rates did not significantly increase at the Supreme Court level in the wake of Chevron. The reason is that as many as three selection biases are probably at work.

To begin with, it is likely that agencies are pressing more aggressive statutory interpretations and getting away with them among lower courts attentive to the government's aggressive deployment of Chevron in its briefs. ${ }^{146}$ As a result, agency interpretations, including some legally shaky ones, routinely prevail on circuit court appeal, and those weak cases are often appealed to the Supreme Court. Conversely, losing parties abandon those cases where the agency has a pretty good legal case and prevails in the court of appeals; Chevron-talk surely discourages some potentially meritorious appeals. This phenomenon, alone, would offer the Justices a sample of appeals where weaker agency interpretations are more prevalent than they would have been absent Chevron. There also may be selection effects in the Justices' screening of appeals. ${ }^{147}$

Another kind of bias precludes us from concluding that Chevron actually marks a more deferential approach by the Court. It is true that, in cases where Chevron was the deference regime invoked by the Court, the agency won $76.2 \%$ of the time, as compared to the overall agency win rate of $68.8 \%$ (and the $68.2 \%$ win rate in non-Chevron cases). This significant differential might signal that the Justices are making a more concerted effort to give agencies the benefit of the doubt in close cases or for broadly written statutes. On the other hand, it might be the case that the Court is more likely to cite Chevron and follow its two-step approach when the majority is prepared to uphold the agency action. ${ }^{148}$ We tend toward the latter explanation, which replicates the pattern we saw for Curtiss-Wright, Seminole Rock, and Skidmore deference.

The clearest effect of Chevron at the Supreme Court level is that it has created an increasingly complicated set of doctrinal debates about when this

145. See, e.g., Hickman \& Krueger, supra note 32, at 1271-79 (Skidmore applied liberally by lower courts and generating considerable deference to agencies); Kerr, supra note 32, at 30-31 (Chevron applied liberally by lower courts and generating considerable deference to agencies).

146. Donald Elliott, a former General Counsel of the Environmental Protection Agency (EPA), says that Chevron allowed the EPA to be more aggressive in pursuing a policy-oriented approach to environmental statutes, at the expense of a legalistic approach, with some confidence that the D.C. Circuit would go along with the agency's interpretations. See E. Donald Elliot, Chevron Matters: How the Chevron Doctrine Redefined the Roles of Congress, Courts, and Agencies in Environmental Law, 16 VILL. ENVTL. L.J. 1, 11-12 (2005).

147. The Justices might not seriously consider most of the cases where the agency has prevailed, so that lower courts will absorb the Chevron message that agencies should usually receive the benefit of the doubt. If the Justices disproportionately homed in on petitions from the Solicitor General, appealing cases where a shaky (but under Chevron possibly winning) agency view has not prevailed (as in Oregon), and on petitions from private parties with strong challenges to shaky agency views that have prevailed in the lower courts (as in Hamdan), the few Chevron-eligible cases that the Court chooses to take would represent a relatively weaker sample of cases than those that are at most Skidmore-eligible.

148. For example, in both Oregon and Hamdan, the Court declined to apply the Chevron framework, notwithstanding strong arguments that the Attorney General (Oregon) and the President (Hamdan) were acting pursuant to congressional delegations of lawmaking authority. That refusal to apply Chevron may have been a product of the Court's skepticism about the executive views in those cases. 
deference regime is applicable (what is now called Chevron Step 0), the approach the Court should take and the evidence it ought to consider to determine whether Congress has directly addressed an issue (Step 1), and the relationship of Chevron to other deference regimes. Mead resolved some of these debates while creating new ones. If Chevron is only dubiously considered a Revolution, it is certainly a Cottage Industry.

Our goal is to deploy our dataset to help understand what the Court has actually been doing in its Chevron cases and Chevron-eligible cases. This is important, because the Court's practice has authoritative weight, binding on lower courts and exercising some stare decisis authority for the Justices themselves. ${ }^{149}$ Based upon our reading of the leading cases and commentaries, our hypotheses were that the Court: (1) regularly applies Chevron to agency interpretations pursuant to congressionally delegated lawmaking authority (Mead); (2) does not give Chevron deference to an agency's interpretation of its own jurisdiction or authority or to a major change in the statutory policy (Oregon); and (3) considers the standard statutory interpretation sources, including legislative history, when engaged in the Chevron inquiries (Chevron itself, as well as Oregon and Hamdan). The data provide some general support to all three propositions but also demonstrate that the Court's practice has been inconsistent, at the very least.

\section{Chevron and Agency Interpretations Pursuant to Congressionally Delegated} Lawmaking Authority

Joined by all the Justices except Scalia, Mead appears to have partially settled the debate within the Court about the conditions for triggering Chevron deference: Chevron is appropriately applied when the agency interpretation has been made pursuant to a congressional delegation of lawmaking authority. ${ }^{150}$ What has remained unanswered, however, is whether this had been the approach the Court has followed since Chevron, as Justice Souter's opinion for the Court suggested, and whether the Court has faithfully followed this methodology since Mead. To answer these kinds of questions, we identified cases where an agency was acting pursuant to a congressional authorization to promulgate rules and orders having the force of law. This proved to be a surprisingly difficult enterprise.

As Professors Thomas Merrill and Kathryn Tongue Watts have demonstrated, for most of the twentieth century there was a particular convention that Congress followed when it intended to give agencies lawmaking authority: Grants

149. For example, Mead rested in part on the Court's characterization of what it had been doing with Chevron since 1984. In Oregon, the debate between the majority and dissenting opinions involved dueling characterizations of how the Court had been applying Chevron.

150. See United States v. Mead Corp., 533 U.S. 218, 227-31 \& n.11 (2001), closely following (and citing) Merrill \& Hickman, supra note 31 . The Court followed and reaffirmed the Mead formulation in Hamdan v. Rumsfeld, 126 S. Ct. 2749, 2773-75 (2006); Gonzales v. Oregon, 546 U.S. 243, 255-75 (2006); and Nat'l Cable \& Telecomms. Ass'n v. Brand X Internet Servs., 545 U.S. 967, 980-81 (2005). 
of rulemaking or adjudication power were not "lawmaking authority" unless accompanied by a statutory provision directly imposing sanctions against those violating those rules or orders. ${ }^{151}$ This conventional wisdom has persisted in the tax area, but has been ignored by judges in other areas, such as labor law. ${ }^{152}$ By 1973, if not earlier, even Congress had "forgotten" about the Merrill-Watts formula and might be understood to have been operating under the assumption that grants of substantive rulemaking or formal adjudicatory power constituted delegation of lawmaking authority. ${ }^{153}$ Thus, it may be fair to say that legislative rulemaking and formal adjudication powers typically reflect a congressional delegation of "lawmaking" authority in laws enacted in 1973 and afterwards, but it is not clear that pre-1973 non-formula delegations should be treated as lawmaking for Chevron purposes. Hence, in the cases we coded as having included a congressional delegation of lawmaking authority to the agency, we further distinguished between those cases where delegation was granted under the Merrill-Watts formula and those cases where delegation was granted only because of the broader approach adopted by the lower courts in the 1970s. That broader "Petroleum Refiners" approach (named after the leading case) presumed that a general grant of rulemaking power was legislative in nature, even when there were no sanctions. ${ }^{154}$

Between Chevron and Hamdan, we identified 267 cases in our population where the agency interpretation was pursuant to a congressional delegation of lawmaking authority to the agency under either the more stringent Merrill-Watts convention or the more inclusive Petroleum Refiners presumption. As explained in Mead, the Chevron two-step inquiry would theoretically govern those appeals. ${ }^{155}$ Yet, as Table 4 reports, of those cases where there was congressional delegation of lawmaking authority, we identified only seventy-six cases where

151. Thomas W. Merrill \& Kathryn Tongue Watts, Agency Rules with the Force of Law: The Original Convention, 116 HARv. L. REv. 467, 526-27 (2002).

152. Id. at 528-45, 570-75. For example, the Supreme Court has assumed that the National Labor Relations Board's adjudicative orders constitute delegated law, see NLRB v. Health Care \& Retirement Corp. of Am., 511 U.S. 571 (1994), but such orders clearly do not under this formula (which everyone would have known in 1935, when Congress passed the NLRA), because the winning party needs to go to court to have the order enforced. See Merrill \& Watts, supra note 151, at 511.

153. See Merrill \& Watts, supra note 151 , at 545-70 (the convention was "erased" by federal judges); id. at 577-78 (a reasonable legislative counsel would, after the judicial erasure, have opined that a general rulemaking or adjudication grant was a "lawmaking" delegation). I asked Professor Merrill: If you had to choose a year by which even congressional drafters would have surely ignored the Merrill-Watts formula and followed a broader approach, what year would you choose? Conceding that an earlier date could be defensible, Merrill felt that the formula would have clearly been obsolete by 1973 .

154. Nat'l Petroleum Refiners Ass'n v. FTC, 482 F.2d 672 (D.C. Cir. 1973) (Skelly Wright, J.); see Merrill \& Watts, supra note 151, at 545-70 (providing a broader context for the Petroleum Refiners revolution in the meaning of these general rulemaking grants).

155. Unless the Court for some reason found a technical exception, such as an agency rulemaking that was actually undertaken in response to litigation or the agency was acting in some way beyond the apparent authorization. (We are assuming that the Justices were not following the Merrill-Watts formula.) 
Table 4. Congressional Delegation of Lawmaking Authority and Invocation of Chevron

\begin{tabular}{|c|c|c|c|c|c|}
\hline & \multicolumn{2}{|c|}{ Chevron Step 0} & \multirow[b]{2}{*}{ Total } \\
\hline & & & No & Yes & \\
\hline \multirow{8}{*}{$\begin{array}{l}\text { Congressional } \\
\text { Delegation of } \\
\text { Lawmaking Authority }\end{array}$} & \multirow[t]{4}{*}{ No } & Count & 738 & 9 & 747 \\
\hline & & $\begin{array}{l}\text { \% Within Congressional } \\
\text { Delegation of } \\
\text { Lawmaking Authority }\end{array}$ & $98.8 \%$ & $1.2 \%$ & $100.0 \%$ \\
\hline & & $\%$ Within Chevron Step 0 & $79.4 \%$ & $10.6 \%$ & $73.7 \%$ \\
\hline & & $\%$ of Total & $72.8 \%$ & $.9 \%$ & $73.7 \%$ \\
\hline & \multirow[t]{4}{*}{ Yes } & Count & 191 & 76 & 267 \\
\hline & & $\begin{array}{l}\% \text { Within Congressional } \\
\text { Delegation of } \\
\text { Lawmaking Authority }\end{array}$ & $71.5 \%$ & $28.5 \%$ & $100.0 \%$ \\
\hline & & \% Within Chevron Step 0 & $20.6 \%$ & $89.4 \%$ & $26.3 \%$ \\
\hline & & $\%$ of Total & $18.8 \%$ & $7.5 \%$ & $26.3 \%$ \\
\hline \multirow[t]{4}{*}{ Total } & & Count & 929 & 85 & 1014 \\
\hline & & $\begin{array}{l}\% \text { Within Congressional } \\
\text { Delegation of } \\
\text { Lawmaking Authority }\end{array}$ & $91.6 \%$ & $8.4 \%$ & $100.0 \%$ \\
\hline & & \% Within Chevron Step 0 & $100.0 \%$ & $100.0 \%$ & $100.0 \%$ \\
\hline & & $\%$ of Total & $91.6 \%$ & $8.4 \%$ & $100.0 \%$ \\
\hline
\end{tabular}

the Court applied the Chevron framework. In short, the Court does not apply the Chevron framework in nearly three-quarters of the cases where it would appear applicable under Mead.

Moreover, whether the delegation was according to the strict Merrill-Watts approach or the more lenient Petroleum Refiners approach appears to make a small difference in how likely the Court is to invoke Chevron. As Table 5 indicates, in Petroleum Refiners delegations Chevron is invoked $23.6 \%$ of the time, while in Merrill-Watts delegations it is invoked somewhat more frequently, in $30.9 \%$ of the cases.

We were quite surprised by these findings. There are some factors that the Justices can plead in amelioration of this astounding inconsistency: the Court in some Chevron-eligible cases did not apply Chevron because the majority believed the agency's proposed rule or interpretation is merely a "litigating position" that no one finds an acceptable basis for Chevron deference, ${ }^{156}$ because the statute so clearly

156. See, e.g., Spector v. Norwegian Cruise Line, Ltd., 545 U.S. 119 (2005) (declining Chevron deference for a proposed agency regulation, but agreeing with Solicitor General amicus on most matters); Wis. Dep't of Health \& Family Servs. v. Blumer, 534 U.S. 473 (2002) (declining Chevron deference to HHS's proposed rule 
Table 5. Type of Delegation and Invocation of Chevron

\begin{tabular}{|c|c|c|c|c|c|}
\hline & & & \multicolumn{2}{|c|}{ Chevron Step 0} & \multirow[b]{2}{*}{ Total } \\
\hline & & & No & Yes & \\
\hline \multirow{8}{*}{\begin{tabular}{|l} 
Type of \\
Delegation
\end{tabular}} & \multirow{4}{*}{$\begin{array}{l}\text { Delegation According } \\
\text { to Strict (Merrill-Watts) } \\
\text { Approach }\end{array}$} & Count & 123 & 55 & 178 \\
\hline & & $\begin{array}{l}\text { \% Within Type of } \\
\text { Delegation }\end{array}$ & $69.1 \%$ & $30.9 \%$ & $100.0 \%$ \\
\hline & & $\begin{array}{l}\text { \% Within Chevron } \\
\text { Step } 0\end{array}$ & $64.4 \%$ & $72.4 \%$ & $66.7 \%$ \\
\hline & & $\%$ of Total & $46.1 \%$ & $20.6 \%$ & $66.7 \%$ \\
\hline & \multirow{4}{*}{$\begin{array}{l}\text { Delegation According } \\
\text { to Lenient (Petroleum } \\
\text { Refiners) Approach }\end{array}$} & Count & 68 & 21 & 89 \\
\hline & & $\begin{array}{l}\% \text { Within Type of } \\
\text { Delegation }\end{array}$ & $76.4 \%$ & $23.6 \%$ & $100.0 \%$ \\
\hline & & $\begin{array}{l}\text { \% Within Chevron } \\
\text { Step } 0\end{array}$ & $35.6 \%$ & $27.6 \%$ & $33.3 \%$ \\
\hline & & $\%$ of Total & $25.5 \%$ & $7.9 \%$ & $33.3 \%$ \\
\hline \multirow[t]{4}{*}{ Total } & & Count & 191 & 76 & 267 \\
\hline & & $\begin{array}{l}\text { \% Within Type of } \\
\text { Delegation }\end{array}$ & $71.5 \%$ & $28.5 \%$ & $100.0 \%$ \\
\hline & & $\begin{array}{l}\text { \% Within Chevron } \\
\text { Step } 0\end{array}$ & $100.0 \%$ & $100.0 \%$ & $100.0 \%$ \\
\hline & & $\%$ of Total & $71.5 \%$ & $28.5 \%$ & $100.0 \%$ \\
\hline
\end{tabular}

supported the agency that invoking a deference regime was unnecessary, ${ }^{157}$ or because the Justice authoring the opinion for the Court chose to apply another deference regime, such as Seminole Rock or Beth Israel. ${ }^{158}$

We subjected the last plea in mitigation to examination under the lens of our dataset. As Table 6 demonstrates, the Court applies a broad range of deference regimes to cases where the agency claims to be operating under a congressional delegation of lawmaking authority, broadly understood. Notably, in nearly as many cases as it chooses to invoke Chevron (seventy-five cases), the Court chooses not to invoke any deference regime at all (sixty-six cases), instead deciding the case based upon ad hoc judicial reasoning. This deepens rather

and its manual); Dep't of Commerce v. U.S. House of Representatives, 525 U.S. 316, 340 (1999) (refusing Chevron deference because agency had been so inconsistent over time).

157. See, e.g., Cal. Dental Ass'n v. FTC, 526 U.S. 756, 765-66 (1999).

158. See, e.g., Jama v. Immigration \& Customs Enforcement, 543 U.S. 335, 248 (2005) (deferring to INS under foreign affairs super-deference approach, citing Mathews v. Diaz, 426 U.S. 67, 81 (1976)); Blumer, 534 U.S. at 473 (deferring to HHS under Skidmore rather than Chevron); Auciello Iron Works, Inc. v. NLRB, 517 U.S. 781 (1996) (deferring to NLRB under Beth Israel, even though Chevron would have been appropriate as well). 
than ameliorates our sense of surprise.

As Table 6 shows, the Court also applied the Chevron framework nine times when there was no congressional delegation of lawmaking authority under either the Merrill-Watts convention or the Petroleum Refiners presumption; this represents $10.7 \%$ of all the Chevron cases in our study. Most, if not all, of these cases are misapplications of Chevron even under the Mead formulation. ${ }^{159}$ For example, Pauley v. Bethenergy Mines, Inc. found the Justices Chevron-deferring to an agency's interpretation of another agency's regulations. ${ }^{160}$ In Presley $v$. Etowah County Commission, a clearer mistake under Mead, the Court applied the Chevron framework to the Department of Justice's interpretation of the Voting Rights Act, even though the statute gives the Department no lawmaking authority and the Department's interpretation was essentially just an advisory opinion to the Court. ${ }^{161}$

Given that Mead clarified the standard for when Chevron is applicable, one might have thought (though we did not) that the Court's practice would become more consistent after Mead. This is not the case. In the pre-Mead period, the Court invoked Chevron in 29.3\% of the cases where there was congressional delegation of lawmaking authority under either Merrill-Watts or Petroleum Refiners. However, after the supposedly clarifying opinion in Mead, the Court invoked Chevron in $23.1 \%$ of such cases, a significantly smaller percentage. Furthermore, the post-Mead Court still applied Chevron to cases where there was no congressional delegation of lawmaking authority under either formula. Our data show this backwards result in $11.3 \%$ of the pre-Mead cases where there was no congressional delegation of lawmaking authority and $7.7 \%$ of the post-Mead cases where there was no congressional delegation of lawmaking authority.

In sum, disaggregating the cases into the pre-Mead and post-Mead periods does not show an era of haphazard application of Chevron before Mead and an era of application according to clearly delineated rules afterwards. Instead, it shows haphazard application over a more than twenty-year period, with the post-Mead era producing results exactly contrary to what the Mead decision announced.

The data on congressional delegation can also be examined through the lens of agency win rates, as we do in Table 7. Overall, the agency win rate for all 1014 cases was $68.8 \%$. The win rate varies moderately depending on whether or

159. Please note that we did not code cases for Mead's dictum that there can be an "implicit" lawmaking delegation to agencies. Even after re-reading Mead countless times, we were able to make no more sense of its standard than was Justice Scalia, who accurately predicted that Mead would produce chaos among lower court judges. See United States v. Mead Corp., 533 U.S. 218, 245 (2001) (Scalia, J., dissenting).

160. 501 U.S. 680, 696-706 (1991). But see id. at 707-08 (Scalia, J., dissenting) (arguing that the Court cannot invoke Chevron under these circumstances).

161. 502 U.S. 491, 508-09 (1992); see id. at 511-14 (Stevens, J., dissenting) (also applying strong deference to the Department's interpretation). The Court followed Presley in Reno v. Bossier Parish Sch. Bd., 520 U.S. 471, 483 (1997). 


\begin{tabular}{|c|c|c|c|c|c|c|}
\hline 恷 & 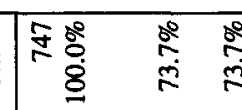 & \begin{tabular}{l|l}
5 & 8 \\
5 & 8 \\
8
\end{tabular} & 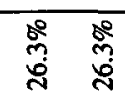 & 吉容 & 客 & $\begin{array}{l}80^{\circ} \\
8\end{array}$ \\
\hline 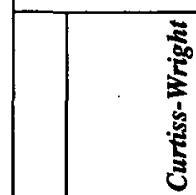 & $\left.\right|^{m} \frac{8}{4}$ & \begin{tabular}{l|l}
0 \\
0
\end{tabular} & $\frac{80}{80}$ & $a g$ & 8 & $2^{\circ}$ \\
\hline हूँ & 小 & पृ & 离 & $=\stackrel{20}{=}$ & 兽 & $\stackrel{5}{=}$ \\
\hline है & 욤 & $\frac{2}{20}$ & 总 & 苾㤂 & $\begin{array}{l}0 \\
8 \\
8\end{array}$ & 赵 \\
\hline 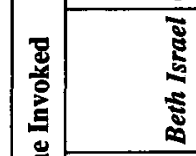 & 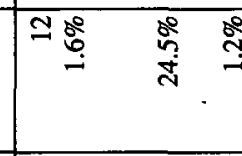 & \begin{tabular}{c|c}
0 \\
4
\end{tabular} & \begin{tabular}{ll}
50 \\
\multirow{2}{*}{}
\end{tabular} & $\vec{F} \underset{\substack{\infty \\
\infty}}{+\infty}$ & 8 & 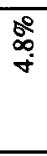 \\
\hline 焉 & F 7000 & 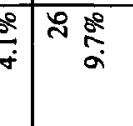 & 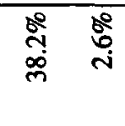 & $\frac{\infty}{0} \frac{8}{6}$ & $\begin{array}{l}8 \\
80 \\
8\end{array}$ & $\frac{8}{50}$ \\
\hline 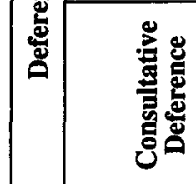 & $\mid \begin{array}{lll}0 \\
\end{array}$ & 年 & 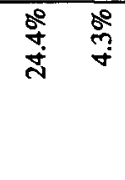 & 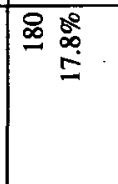 & $\begin{array}{l}80 \\
8 \\
8\end{array}$ & 兽 \\
\hline 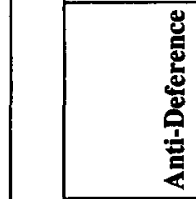 & 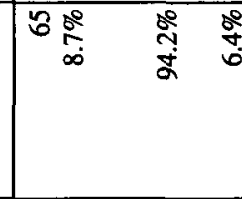 & \begin{tabular}{l|l} 
\\
0
\end{tabular} & 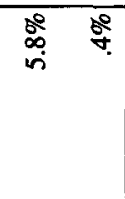 & 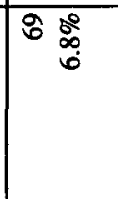 & $\begin{array}{l}80 \\
8 \\
8\end{array}$ & 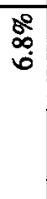 \\
\hline 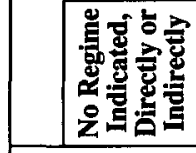 & 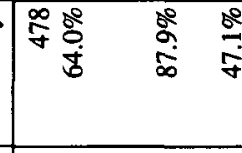 & $\int \frac{4}{4}$ & 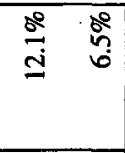 & 青总 & 苂 & 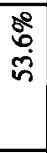 \\
\hline & 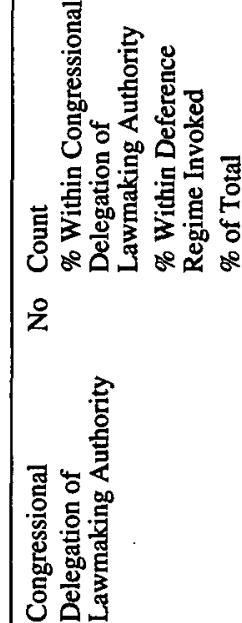 & 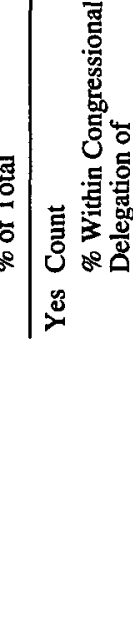 & 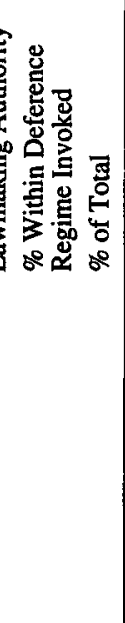 & 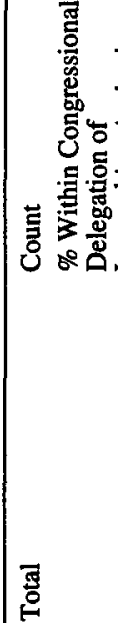 & 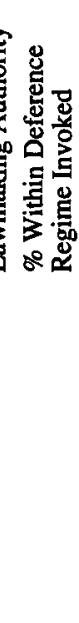 & \\
\hline
\end{tabular}


Table 7. A Comparison of Agency Win Rates

\begin{tabular}{|c|c|}
\hline Overall & $68.8 \%$ \\
\hline Delegation of Lawmaking Authority & $71.9 \%$ \\
\hline Delegation According to Merrill-Watts & $74.2 \%$ \\
\hline Delegation Only According to Petroleum Refiners & $67.4 \%$ \\
\hline No Delegation & $67.7 \%$ \\
\hline Chevron Cases & $76.2 \%$ \\
\hline Chevron Cases with Congressional Delegation & $78.7 \%$ \\
\hline According to Merrill-Watts & $81.5 \%$ \\
\hline Only According to Petroleum Refiners & $71.4 \%$ \\
\hline Chevron Cases Without Congressional Delegation & $55.6 \%$ \\
\hline
\end{tabular}

not there is a delegation of lawmaking authority and, if so, what type. The Court upholds the agency interpretation more than the aggregate average $(74.2 \%$ of the time) when there has been Merrill-Watts delegation and slightly less than average when there has just been Petroleum Refiners but not Merrill-Watts delegation (67.4\% of the time) or no delegation (67.7\% of the time).

As noted above, the Chevron cases display a significantly higher win rate (76.2\%) than the overall win rate $(68.8 \%)$. However, in those Chevron cases where there has not been a congressional delegation of lawmaking authority, the win rate is significantly lower than the average (55.6\%). Thus, while the Court may be willing to apply Chevron to cases where the agency has not been delegated lawmaking authority, it does not appear as likely to let the agency win those cases. Additionally, in those Chevron cases where there has been a delegation of lawmaking authority, there is significant variation between those cases with Merrill-Watts delegation (which win $81.5 \%$ of the time) and those cases with only Petroleum Refiners delegation (which win $71.4 \%$ of the time). Thus, a case where the Court applies Chevron when there has been just a Petroleum Refiners delegation of lawmaking authority (which typically has no connection with original congressional expectations) will fare not much better than the average case in our 1014 case population, but a case where the Court applies Chevron in the presence of Merrill-Watts delegation (which is much more likely to reflect congressional expectations) will fare significantly better. Thus, although the Court pays lip service to a broader understanding of delegation of lawmaking authority in Mead, it appears that a formal, strict delegation is associated with higher agency win rates in Chevron cases.

In sum, congressional delegation is not a solid predictor of when the Court will invoke Chevron, but it is correlated with, and may influence, the agency's chances of prevailing once Chevron has been invoked. 
2. Chevron and Agency Interpretations Involving Jurisdictional and "Fundamental Policy" Issues

Justice Scalia maintains that Chevron deference fully applies to an agency interpretation of its own jurisdiction or authority. ${ }^{162}$ His main argument is that there is "no discernible line between an agency's exceeding its authority and an agency's exceeding authorized application of its authority."163 In other words, any test asking the Court to differentiate between when the agency is interpreting its own jurisdiction or authority and when it is merely exercising delegated lawmaking authority would be too difficult to administer; hence, Chevron deference should apply to both contexts.

We are not so sure about that. Contrast wholesale and retail applications of a statute. When an agency expands its regulations to a new category of applications, it is interpreting its own jurisdiction or regulatory authority; this is a wholesale application of a statute. When the agency applies its regulations to a matter of detail, it is not interpreting its own jurisdiction or regulatory authority; this is a retail application of a statute. For an example from the Oregon Aid-in-Dying Case, whether the Controlled Substances Act (CSA) gives the Attorney General preemptive authority over the use of drugs for aid-in-dying is a question about a wholesale application of a statute, while the issue of how the Attorney General can regulate drugs over which he is known to have jurisdiction is a question about the retail application of a statute. ${ }^{164}$ As a matter of capacity, we believe that the Court is capable of distinguishing between wholesale and retail applications of a statute. Unlike Justice Scalia, we do not find this to be outside the realm of judicial competence.

More importantly, Justice Scalia's position is in some tension with Mead's holding that Chevron rests upon Congress's delegation of lawmaking authority to the agency; in that event, one would expect the Court to take care that there actually has been such a delegation. ${ }^{165}$ Reflecting this logic, there are in fact a number of precedents where the Court has taken a non-deferential approach to agency interpretations of their own jurisdiction or authority. For example, the Court in FDA v. Brown \& Williamson Tobacco Corp. ${ }^{166}$ ruled that Congress did not delegate to the FDA statutory authority to regulate nicotine as a "drug" and cigarettes as "drug delivery devices." 167 Even though the statutory text defined

162. Miss. Power \& Light Co. v. Mississippi ex rel. Moore, 487 U.S. 354, 381-82 (1988) (Scalia, J., concurring in the judgment), responding to id. at 386-87 (Brennan, J., dissenting) (arguing that no deference should be afforded agency interpretations of "the scope of their jurisdiction").

163. Id. at 381 (Scalia, J., concurring in the judgment).

164. Are some pain-ameliorating drugs prone to cause early death, such that they should be included in the regulation? Or should they be regulated in a more subtle way? What penalties should be used against doctors violating the Attorney General's directive?

165. See, e.g., Emest Gellhom \& Paul Verkuil, Controlling Chevron-Based Delegations, 20 CARDozo L. Rev. 989, 1006-17 (1999); Merrill \& Hickman, supra note 31, at 909-11. But see Kevin M. Stack, The Statutory President, 90 Iowa L. Rev. 539, 594-95 (2005) (agreeing with the Scalia position).

166. 529 U.S. 120 (2000).

167. Id. at $142-43$. 
Table 8. Invocation of Chevron when an Agency Interpretation of Its Own Jurisdiction and Regulatory Authority Is at Issue

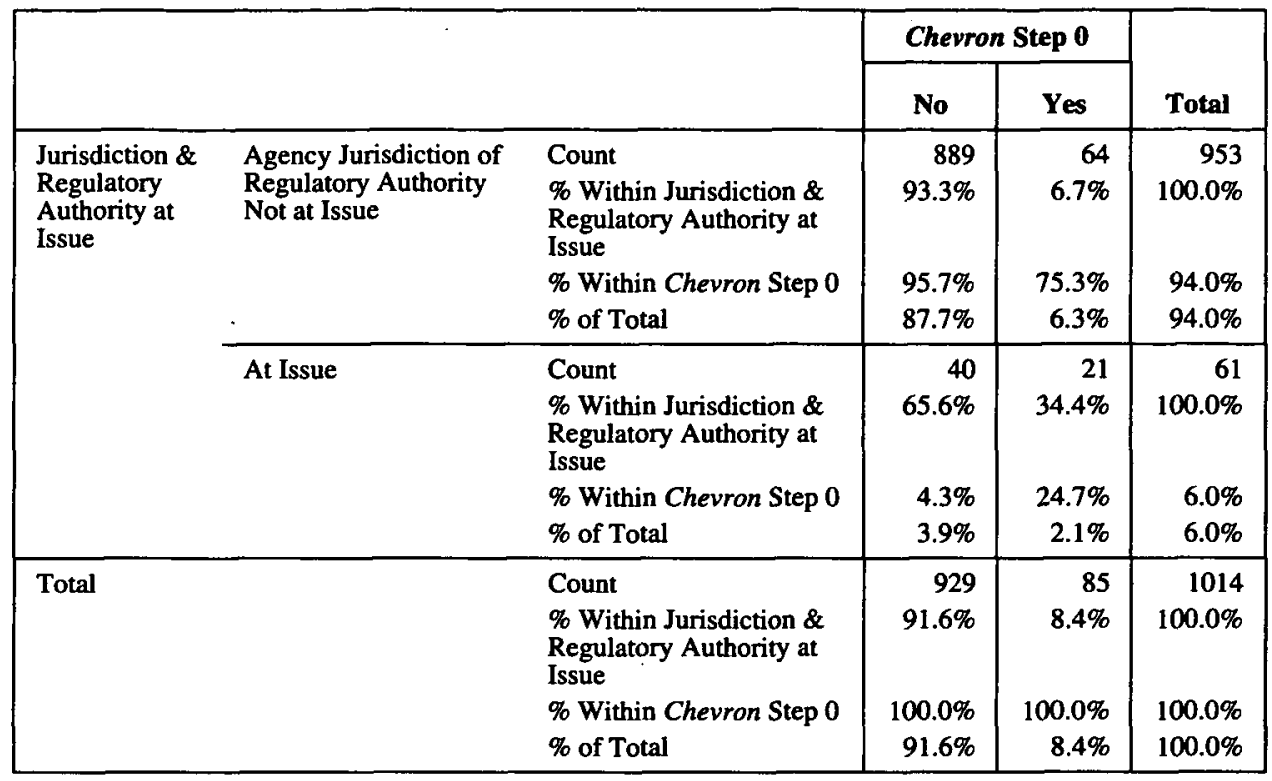

"drug" broadly enough to include nicotine, the Court did not defer to the FDA's assertion of jurisdiction over a broad new category of applications (that is, its wholesale decision). ${ }^{168}$

Indeed, our data suggest that the Court may in fact be drawing such lines in its Chevron jurisprudence. We identified sixty-one cases (including the Oregon Aid-in-Dying Case and the FDA Tobacco Case) where the agency was interpreting its own jurisdiction or authority, in the sense we suggest above. These are broken down in Table 8.

The Court applied Chevron deference in only $34.4 \%$ of those cases. In the other $65.6 \%$, the Court applied another less stringent deference regime or no deference regime at all; these are reported in Table 9.

On the other hand, the twenty-one cases in which the Court applied Chevron to an agency interpretation of its own jurisdiction or regulatory authority represent $25 \%$ of all of the cases in which the Court applied Chevron. This is a sizeable chunk of the Court's Chevron jurisprudence. Thus, in the end, the evidence is mixed as to whether an agency interpretation of its own jurisdiction or regulatory authority is a matter for Chevron deference.

A related question (and one raised in the Oregon Aid-in-Dying Case) is whether Chevron deference should apply when the agency is making a major change in statutory policy. Although it is now an important moral and policy issue at the national as well as state level, the aid-in-dying issue was not one

168. Id. at $159-60$. 


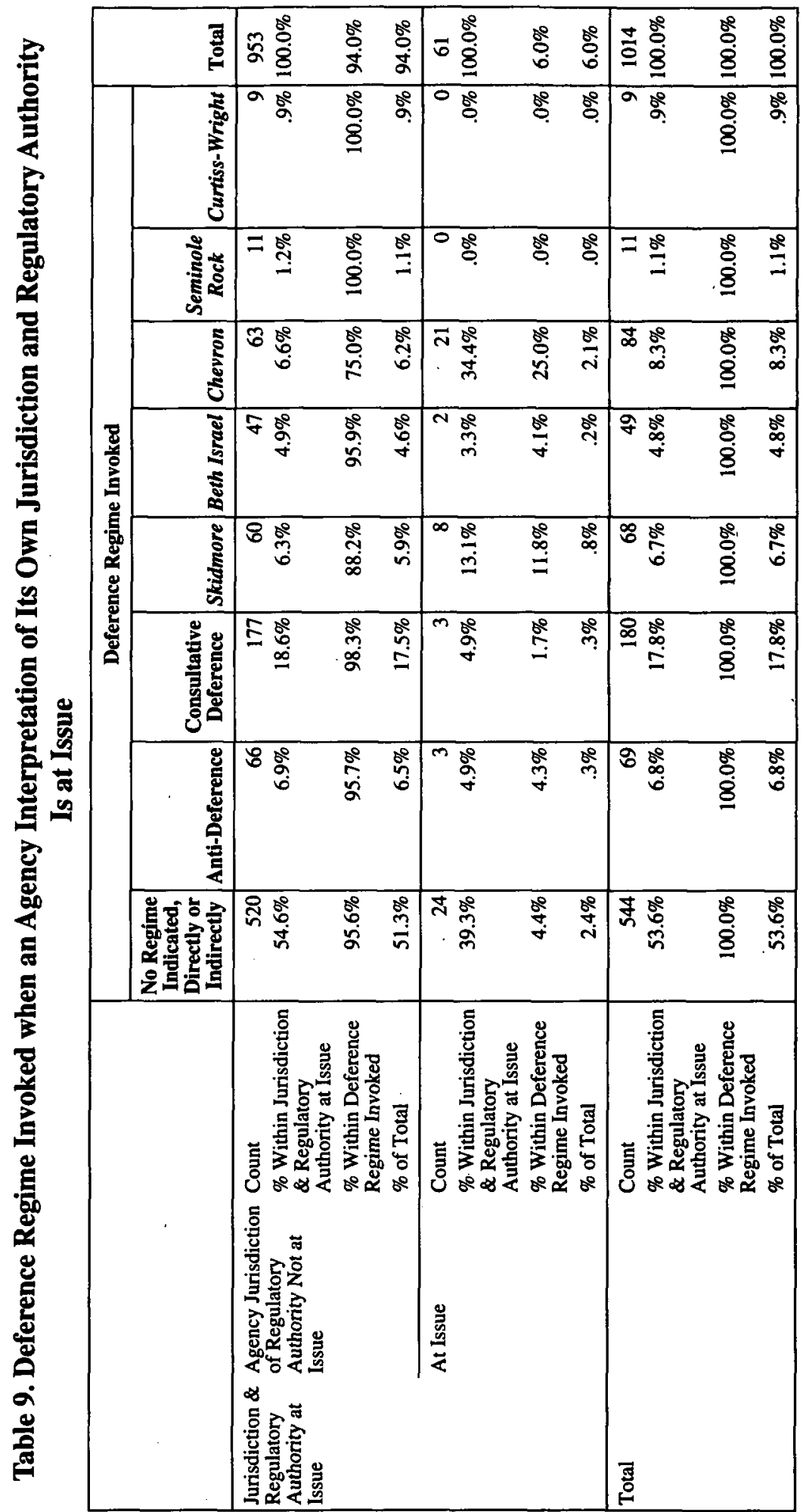


Table 10. Continuity of Agency Position and Invocation of Chevron

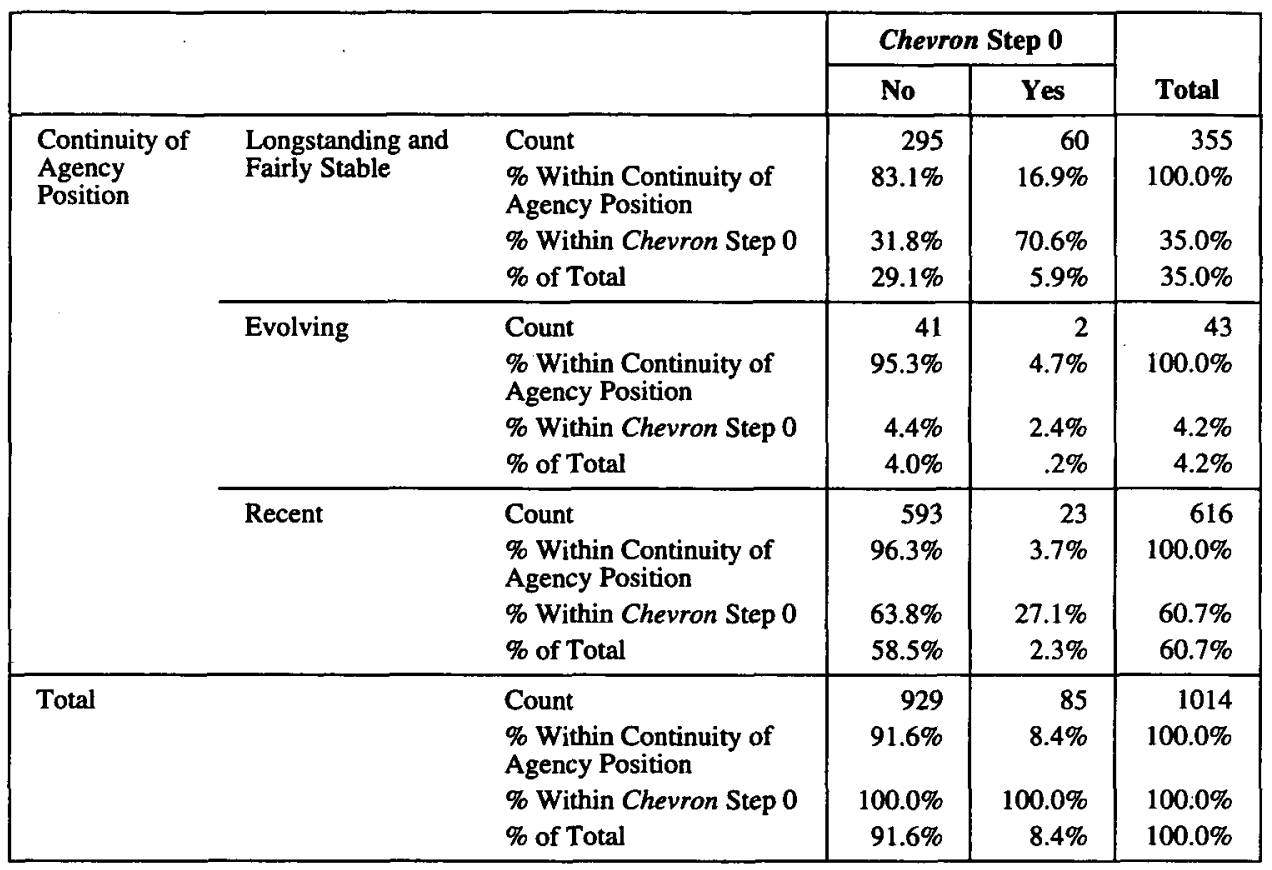

Congress gave any thought to in 1970, when it adopted the CSA. The Oregon majority felt that this was too big an issue to leave to administrative decisionmaking without a clearer congressional delegation. "Congress ... does not alter the fundamental details of a regulatory scheme in vague terms or ancillary provisions-it does not, one might say, hide elephants in mouseholes."169

We did not directly code for whether an agency interpretation altered fundamental details of a regulatory scheme, but we did code all agency interpretations as either longstanding, recent, or evolving. We then broke down the category of recent interpretations into those that arose because (1) the issue was new for the agency; (2) there was a new administration; (3) the statute was new; (4) the agency changed its mind based upon practical experience; and (5) the agency developed the interpretation as a litigating position. The data, summarized in Table 10, reveal that the overwhelming majority of the cases in which the Court invokes Chevron $(70.6 \%)$ involve a longstanding or fairly stable interpretation. ${ }^{170}$ Indeed this category dwarfs applications of Chevron where the agency

169. Gonzales v. Oregon, 546 U.S. 243, 267 (2006) (quoting Whitman v. Am. Trucking Ass'ns, Inc., 531 U.S. 457, 468 (2001) (Scalia, J.)). In Oregon, Justice Scalia responded that Congress made a clear judgment that controlled substances cannot be used for harmful purposes, such as he considered "assisted suicide" to be. Id. at 285-86 (Scalia, J., dissenting).

170. We took a practical view of what agency interpretations are "Iongstanding." We included agency positions publicly taken contemporaneously with or soon after the enactment of the relevant statute but by no means limited the category to such situations. Thus, we included current agency 
Table 11. New Agency Interpretations and Invocation of Chevron

\begin{tabular}{|c|c|c|c|c|c|}
\hline & & & \multicolumn{2}{|c|}{ Chevron Step 0} & \multirow[b]{2}{*}{ Total } \\
\hline & & & No & Yes & \\
\hline \multirow{20}{*}{$\begin{array}{l}\text { If Agency Position } \\
\text { Is Recent, Why }\end{array}$} & New Issue for Agency & Count & 543 & 17 & 560 \\
\hline & & $\begin{array}{l}\text { \% Within if Agency } \\
\text { Position Is Recent, Why }\end{array}$ & $97.0 \%$ & $3.0 \%$ & $100.0 \%$ \\
\hline & & \% Within Chevron Step 0 & $91.4 \%$ & $73.9 \%$ & $90.8 \%$ \\
\hline & & $\%$ of Total & $88.0 \%$ & $2.8 \%$ & $90.8 \%$ \\
\hline & New Administration & Count & 34 & 5 & 39 \\
\hline & & $\begin{array}{l}\text { \% Within if Agency } \\
\text { Position Is Recent, Why }\end{array}$ & $87.2 \%$ & $12.8 \%$ & $100.0 \%$ \\
\hline & & \% Within Chevron Step 0 & $5.7 \%$ & $21.7 \%$ & $6.3 \%$ \\
\hline & & $\%$ of Total & $5.5 \%$ & $.8 \%$ & $6.3 \%$ \\
\hline & New Statute & Count & 5 & $\mathbf{0}$ & 5 \\
\hline & & $\begin{array}{l}\% \text { Within if Agency } \\
\text { Position Is Recent, Why }\end{array}$ & $100.0 \%$ & $.0 \%$ & $100.0 \%$ \\
\hline & & $\%$ Within Chevron Step 0 & $.8 \%$ & $.0 \%$ & $.8 \%$ \\
\hline & & $\%$ of Total & $.8 \%$ & $.0 \%$ & $.8 \%$ \\
\hline & Practical Experience & Count & 10 & 1 & 11 \\
\hline & & $\begin{array}{l}\text { \% Within if Agency } \\
\text { Position Is Recent, Why }\end{array}$ & $90.9 \%$ & $9.1 \%$ & $100.0 \%$ \\
\hline & & \% Within Chevron Step 0 & $1.7 \%$ & $4.3 \%$ & $1.8 \%$ \\
\hline & & $\%$ of Total & $1.6 \%$ & $.2 \%$ & $1.8 \%$ \\
\hline & Litigating Position & Count & 2 & 0 & 2 \\
\hline & & $\begin{array}{l}\text { \% Within if Agency } \\
\text { Position Is Recent, Why }\end{array}$ & $100.0 \%$ & $.0 \%$ & $100.0 \%$ \\
\hline & & \% Within Chevron Step 0 & $.3 \%$ & $.0 \%$ & $.3 \%$ \\
\hline & & $\%$ of Total & $.3 \%$ & $.0 \%$ & $.3 \%$ \\
\hline \multirow[t]{4}{*}{ Total } & & Count & 594 & 23 & 617 \\
\hline & & $\begin{array}{l}\text { \% Within if Agency } \\
\text { Position Is Recent, Why }\end{array}$ & $96.3 \%$ & $3.7 \%$ & $100.0 \%$ \\
\hline & & \% Within Chevron Step 0 & $100.0 \%$ & $100.0 \%$ & $100.0 \%$ \\
\hline & & $\%$ of Total & $96.3 \%$ & $3.7 \%$ & $100.0 \%$ \\
\hline
\end{tabular}

interpretation is recent $(27.1 \%)$ or evolving $(2.4 \%)$.

Note, however, that within those decisions that apply Chevron to a recent agency interpretation, the overwhelming majority (73.9\%) are interpretations that are new because they represent new issues for the agency; the data are summarized in Table 11 . These seventeen cases represent $20.2 \%$ of all of the cases where the court applies Chevron, which is not an insignificant number. That is to say, when the Court chooses to apply Chevron to recent opinions, it most frequently does so when those opinions are new issues for the agency.

Nevertheless, when reading these figures one should remember that Chevron

interpretations that no one in the case denied were consistent over time; federal prosecutors' interpretations of criminal statutes that had been advanced (successfully in most cases) in previous reported cases; and even amicus brief positions that were supported by prior administrative guideposts, including informal ones such as letters, publications, and the like. 
is only being applied in 84 of 1014 cases. ${ }^{171}$ Thus, the overwhelming majority of all cases-new, recent, or otherwise-do not receive deference under the Chevron regime.

\section{Chevron and Interpretive Methodology: The Use of Legislative History}

In determining whether Congress had delegated lawmaking authority to the Attorney General on the aid-in-dying issue, Justice Kennedy's opinion for the Oregon Court considered the legislative history of the CSA, including committee reports that explained what Congress was up to. ${ }^{172}$ The dissenters did not. The different approaches in the Oregon Aid-in-Dying Case mirror a larger debate in the Court over whether legislative history is applicable to the Chevron inquiry. The Court's main critic of legislative history is Justice Scalia. Supporting Justice Scalia's approach, some of the leading Chevron opinions-including one by Justice Kennedy-pointedly ignore relevant legislative history and determine deference issues only by reference to statutory text and structure. ${ }^{173}$

If one examines the Court's overall practice, however, it is all but settled that relevant legislative history is admissible in the Chevron inquiry. To begin with, Justice Stevens's opinion for the Court in Chevron itself examined legislative history to determine whether Congress had addressed the interpretive issue resolved by the agency. ${ }^{174}$ The Court explicitly confirmed this practice after Chevron. In Wisconsin Public Intervenor v. Mortier, ${ }^{175}$ the Court Chevrondeferred to an agency interpretation that the federal pesticide law did not preempt state law. In determining whether Congress had directly addressed this question (Chevron Step 1), the Court examined the legislative history as well as the statutory text. ${ }^{176}$ Mortier is particularly illuminating, because Justice White's opinion marshalling legislative history won over the votes of Chief Justice Rehnquist and Justice O'Connor, who had originally thought that the statutory scheme "occupied the field" and therefore preempted state law. ${ }^{177}$ That case is also significant because it saw Justice Scalia mount a full-scale assault on the Court's reliance on legislative history-an assault that drew no support from any other Justice. ${ }^{178}$

171. Note that the Court actually applies the Chevron two-step in eighty-five cases. However, in one of those cases the Court used Curtiss-Wright deference as the actual basis for its decision. Hence, we use eighty-four as the baseline for the number of Chevron cases in our study.

172. See Oregon, 546 U.S. at 265-66.

173. Compare, e.g., K Mart Corp. v. Cartier, Inc., 486 U.S. 281, 293-94 (1988) (Kennedy, J., delivering the judgment of the Court) (affirming two agency rules and abrogating a third, based upon the statutory text), with id. at 300-09 (Brennan, J., concurring in part and dissenting in part) (agreeing with Kennedy on two regulations, based upon detailed examination of legislative history).

174. Chevron, U.S.A., Inc. v. Natural Res. Def. Council, Inc., 467 U.S. 837, 862-64 (1984).

175. 501 U.S. 597 (1991).

176. Id. at 609-14.

177. See Conference Notes for Mortier, in Blackmun Papers, supra note 6, Box 573, Folder 1.

178. Mortier, 501 U.S. at 616-23 (Scalia, J., concurring in the judgment). Ironically, Justice Scalia joined Justice O'Connor's opinion in Brown \& Williamson, where the Court's rejection of the FDA's interpretation rested upon twenty-five pages of lavish attention to legislative history of various 
Table 12. Invocation of Chevron and the Use of Legislative History

\begin{tabular}{|c|c|c|c|c|c|c|}
\hline & \multicolumn{4}{|c|}{ Legislative History in Majority } & \multirow[b]{2}{*}{ Total } \\
\hline & & $\begin{array}{c}\text { No } \\
\text { Reference }\end{array}$ & $\begin{array}{c}\text { Some } \\
\text { Reference in } \\
\text { Analysis but } \\
\text { Without } \\
\text { Meaningful } \\
\text { Reliance To } \\
\text { Advance } \\
\text { Reasoning }\end{array}$ & $\begin{array}{c}\text { Genuine } \\
\text { Positive } \\
\text { Reliance in } \\
\text { Reasoning } \\
\text { That Helps } \\
\text { Bring } \\
\text { About the } \\
\text { Result } \\
\text { Reached }\end{array}$ & $\begin{array}{l}\text { Source Is } \\
\text { "a" or "the" } \\
\text { Determining } \\
\text { Factor in the } \\
\text { Reasoning } \\
\text { Process }\end{array}$ & \\
\hline \multirow{8}{*}{$\begin{array}{l}\text { Chevron } \\
\text { Step } 0\end{array}$} & Count & 413 & 129 & 213 & 174 & 929 \\
\hline & \% Within Chevron Step 0 & $44.5 \%$ & $13.9 \%$ & $22.9 \%$ & $18.7 \%$ & $100.0 \%$ \\
\hline & $\begin{array}{l}\text { \% Within Legislative } \\
\text { History in Majority }\end{array}$ & $92.8 \%$ & $89.6 \%$ & $89.9 \%$ & $92.6 \%$ & $91.6 \%$ \\
\hline & $\%$ of Total & $40.7 \%$ & $12.7 \%$ & $21.0 \%$ & $17.2 \%$ & $91.6 \%$ \\
\hline & Count & 32 & 15 & 24 & 14 & 85 \\
\hline & $\%$ Within Chevron Step 0 & $37.6 \%$ & $17.6 \%$ & $28.2 \%$ & $16.5 \%$ & $100.0 \%$ \\
\hline & $\begin{array}{l}\text { \% Within Legislative } \\
\text { History in Majority }\end{array}$ & $7.2 \%$ & $10.4 \%$ & $10.1 \%$ & $7.4 \%$ & $8.4 \%$ \\
\hline & $\%$ of Total & $3.2 \%$ & $1.5 \%$ & $2.4 \%$ & $1.4 \%$ & $8.4 \%$ \\
\hline \multirow[t]{4}{*}{ Total } & Count & 445 & 144 & 237 & 188 & 1014 \\
\hline & \% Within Chevron Step 0 & $43.9 \%$ & $14.2 \%$ & $23.4 \%$ & $18.5 \%$ & $100.0 \%$ \\
\hline & $\begin{array}{l}\text { \% Within Legislative } \\
\text { History in Majority }\end{array}$ & $100.0 \%$ & $100.0 \%$ & $100.0 \%$ & $100.0 \%$ & $100.0 \%$ \\
\hline & \% of Total & $43.9 \%$ & $14.2 \%$ & $23.4 \%$ & $18.5 \%$ & $100.0 \%$ \\
\hline
\end{tabular}

Our dataset supports Mortier's suggestion that legislative history is relevant at any stage of the Chevron inquiry. In $62.3 \%$ of the cases that apply the Chevron test, the Court provides at least some reference to legislative history. In $44.7 \%$ of the Chevron cases, there is either a genuine positive reliance on legislative history, or it is a determining factor in the Court's reasoning process.

Moreover, as Table 12 demonstrates, the Court actually references legislative history more often in Chevron cases than in non-Chevron cases $(44.5 \%$ of non-Chevron cases fail to mention legislative history while only $37.6 \%$ of Chevron cases make this omission). Thus, there can no longer be serious debate whether Supreme Court precedent instructs judges to consider relevant legislative history in applying Chevron deference. It does.

\section{PREDICTING SUPREME COURT BEHAVIOR}

\section{Predicting Deference Regime Invoked}

To this point, we have discussed the deference regimes on the Court's own

tobacco-regulatory statutes. FDA v. Brown \& Williamson Tobacco Corp., 529 U.S. 120, 130-55 (2000) (examining committee hearing testimony and colloquy, as well as committee reports, for tobaccoregulatory statutes). Further, Justice Scalia has in some prominent Chevron cases cited and relied on legislative history himself in arguing Step 1 issues. See, e.g., Babbitt v. Sweet Home Chapter of Cmtys. for a Great Or., 515 U.S. 687, 726-32 (1995) (Scalia, J., dissenting). 
terms. That is, we have examined whether the factors laid out by the Court in its own opinions accurately predict when particular deference regimes will be invoked. Does the Court apply Chevron to cases where there has been congressional delegation of lawmaking authority? Does the Court regularly invoke Skidmore when an agency is interpreting its own regulations? And so on. The data presented above demonstrate that the Court's actual deference practice bears little resemblance to the orderly and predictable deference practice outlined by the Court's seminal opinions. The Court does not apply deference regimes in a foreseeable manner, with the regime invoked tightly correlated to the cues for invocation described by the Court. Rather, the Court invokes deference regimes in a manner that is seemingly sporadic and haphazard. In practice, deference regimes, as applied by the Court, do not capture nearly all of the cases that they are supposed to and often times ensnare cases that ought to be resolved by other deference tests.

Thus, in this subpart, we examine whether factors other than those laid out by the Court might make more sense of the Court's deference practice. Is the Court's deference practice actually being organized along lines not laid out in the Court's opinions? In particular, we examine the influence of subject matter on the deference regime invoked. Subject matter is certainly not the only variable that could potentially drive the Court's choice of deference regime, but it does possess certain features that make it well suited for analysis in this context: (1) subject matter is easy to code objectively, meaning that our categorizations reflect the manner in which the Justices themselves would have seen the cases, (2) subject matter is not included as a trigger factor under any of the Court's current deference regimes, meaning it presents a true alternative to the doctrine that the Court ostensibly should be following, and (3) there are few enough subject-matter groupings that most subject-matter subsets are of a size large enough to draw inferences from (this is not the case with other variables, such as the agency at issue, which result in numerous subgroups of cases with fewer than five members).

We emphasize, however, that our conclusions are tentative, that they are based on descriptive statistics and not predictive modeling, and that variables other than subject matter may well be organizing the Court's deference practice. Thus, further work in this area must certainly be done. Nonetheless, we offer some interesting findings.

In order to investigate the influence of subject matter on deference regime invoked, we grouped the cases into twenty-three general subject-matter areas. Although many cases involved more than one subject area, for ease of analysis, we identified cases only by the dominant subject area at issue. Thus, for example, while there are more than ninety cases that touch on foreign affairs and national security, fewer than ten cases were coded under the foreign affairs and national security subject area.

Assembled in Table 13, the data indicate that, regardless of subject area, ad hoc judicial reasoning reigns. In eighteen of twenty-three subject areas, at least 
Table 13. Percentage of Cases Where No Deference Regime Is Invoked, by Subject Area

\begin{tabular}{|l|l|l|l|l|}
\hline \multicolumn{1}{|c|}{$<30 \%$} & \multicolumn{1}{|c|}{$\mathbf{4 0 - 5 0 \%}$} & \multicolumn{1}{c|}{$\mathbf{5 0 - 6 0 \%}$} & \multicolumn{1}{c|}{$\mathbf{6 0 - 7 0 \%}$} & \multicolumn{1}{c|}{$>\mathbf{7 0 \%}$} \\
\hline Entitlement Programs & Criminal Law & Business Regulation & Federal Lands & Bankruptcy \\
\hline $\begin{array}{l}\text { Foreign Affairs \& } \\
\text { National Security* }\end{array}$ & Energy & Civil Rights & Indian Affairs & Federal Government \\
\hline Housing* & Environment & Education* & Maritime* & Federal Procedure \\
\hline Labor Relations & Health \& Safety* & Intellectual Property & & \\
\hline Transportation & Immigration & Pensions & & \\
\hline & Telecom* & Tax & & \\
\hline
\end{tabular}

*Indicates subject area with fewer than ten cases.

the plurality of cases were disposed of by the Court without the invocation of a deference regime. In twelve subject areas, the Court disposed of the majority of all cases without invoking a deference regime.

What's more, in thirteen subject areas-bankruptcy, business regulation, civil rights, criminal law, energy, federal procedure, federal lands, Indian affairs, intellectual property, maritime, pensions, and tax-consultative deference was the next most common means by which the Court disposed of cases. Hence, in many subject areas, well over $75 \%$ of cases were disposed of through means that did not involve the invocation of a named deference regime. For example, in $52.5 \%$ of pensions (ERISA) cases the Court did not invoke a deference regime, and in $32.5 \%$ the Court employed consultative deference, meaning that $87.5 \%$ of pensions cases were resolved without the aid of a named deference test.

Indeed, a named deference regime was second to the failure to invoke a deference regime in only three subject areas with more than ten cases. In these areas - entitlement programs, environment, and labor relations-when the Court chose to invoke a deference regime, it most often invoked Chevron, in $29.8 \%$, $26.3 \%$, and $21.3 \%$ of the cases respectively. Please recall that this does not mean that Chevron will, or is even likely to, be invoked in cases falling under these subject areas, for in each of them, the Court disposed of over $70 \%$ of the cases without invocation of the Chevron two-step.

When one approaches the question in reverse-examining the subject-matter makeup of cases under particular deference regimes rather than the deference regimes invoked in cases falling under a particular subject matter-certain illuminating facts emerge. These include the following:

- $18 \%$ of the cases where no deference regime is invoked are federal procedure cases. This is the only subject area that makes up more than $10 \%$ of the no-deference category. It is also a logical finding given that the Court should be expected to interpret federal procedural rules on its own, rather than deferring to agency interpretations. 
Table 14. Subject Matter and Deference Regime Invoked

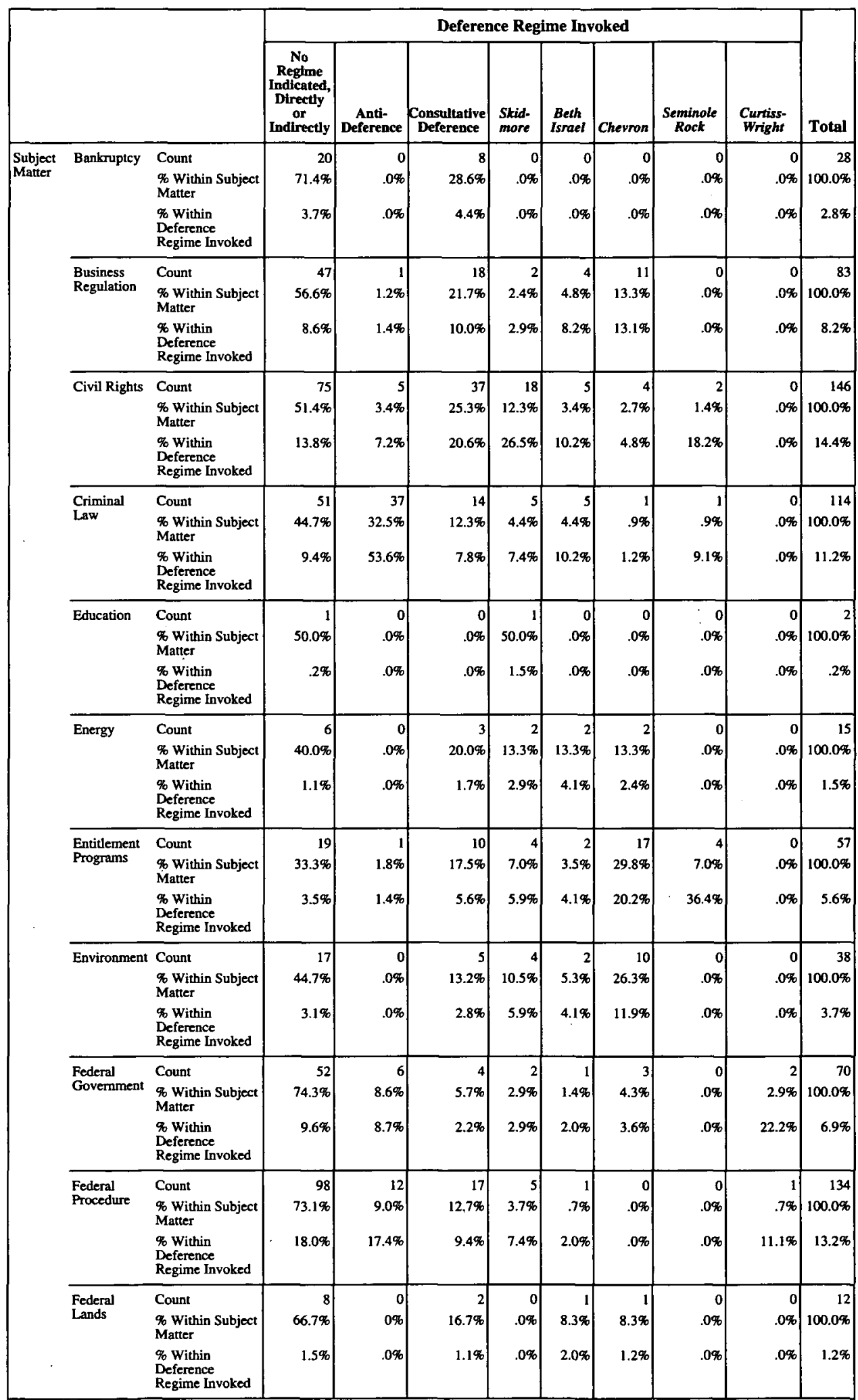


Table 14. Subject Matter and Deference Regime Invoked

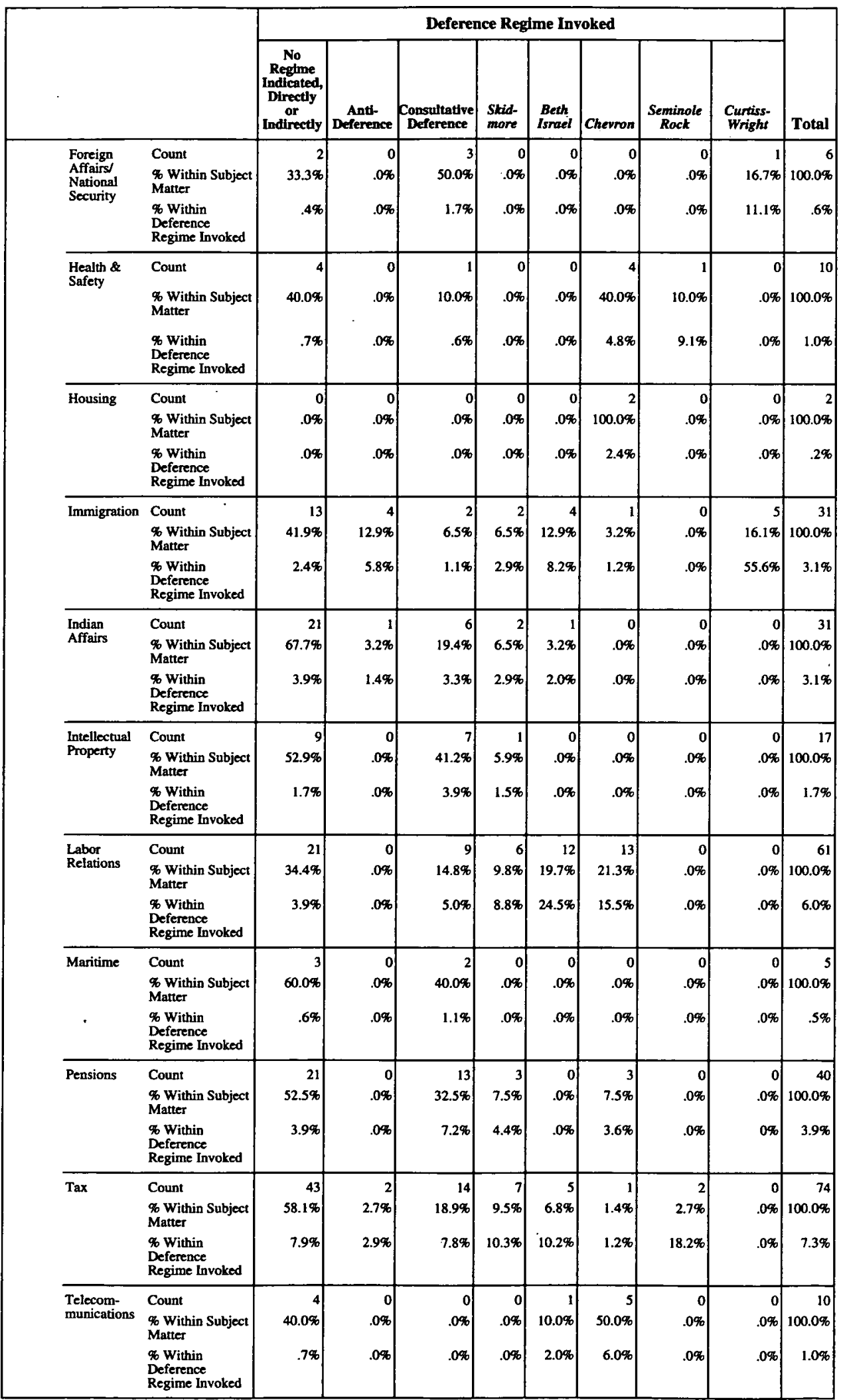


Table 14. Subject Matter and Deference Regime Invoked

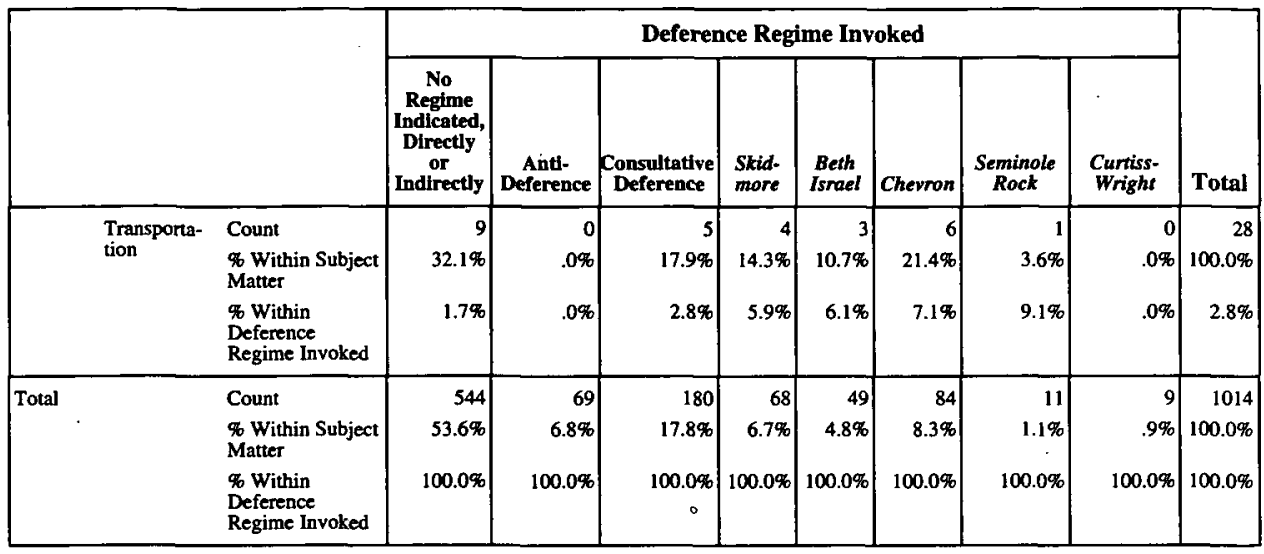

- Criminal cases and federal procedure cases are the largest subsets of anti-deference cases, comprising $53.6 \%$ and $17.4 \%$ of those cases, respectively. This is also unsurprising, because of the rule of lenity's prominent role in both criminal law and the anti-deference regime. .

- $20 \%$ of consultative deference cases and $26.5 \%$ of Skidmore cases are civil rights cases. This is the only subject area that makes up more than $11 \%$ of the cases in these deference regimes.

- $24.5 \%$ of the Beth Israel cases are labor relations cases; this is the main reason we named the residual category of Chevron-like deference cases "Beth Israel," to reflect the primacy of labor cases in this category.

- About $60 \%$ of the Chevron cases fall into one of four subject areas: business regulation (13.1\%), entitlement programs (20.2\%), environmental law (11.9\%), and labor relations (15.5\%).

Thus, in some cases, if the Court has invoked a particular deference regime, our data offer a decent idea of what subject area that case might fall into. For example, a Beth Israel case has about a $25 \%$ likelihood of having to do with labor relations. Our data do not, however, offer guidance as to why named deference regimes are applied to some cases and not others; the data do not explain the decisionmaking process whereby very few cases get analyzed through the lens of deference regimes while the overwhelming majority are approached through ad hoc judicial reasoning. In the end, then, subject area proves to be no more useful in predicting the deference regime the Court will invoke than the oft-ignored factors the court lays out itself.

\section{Predicting Agency Win Rates}

In our analysis of the continuum of deference, we noted the win rates that accompanied different deference regimes. Now we examine win rates in greater depth, looking not only at the influence of the deference regime invoked, but 
Table 15. Agency Win Rates for Deference Regimes (Lowest to Highest)

\begin{tabular}{|l|c|}
\hline \multicolumn{1}{|c|}{ Deference Regime } & $\begin{array}{c}\text { Agency Win } \\
\text { Rate }\end{array}$ \\
\hline Anti-Deference & $36.2 \%$ \\
\hline No Deference Regime Invoked & $66.0 \%$ \\
\hline Overall Win Rate Across Deference Regimes & $68.8 \%$ \\
\hline Skidmore & $73.5 \%$ \\
\hline Beth Israel & $73.5 \%$ \\
\hline Chevron & $76.2 \%$ \\
\hline Consultative Deference & $80.6 \%$ \\
\hline Seminole Rock & $90.9 \%$ \\
\hline Curtiss-Wright & $100.0 \%$ \\
\hline
\end{tabular}

also at other variables-namely subject matter, the format of the agency. interpretation, and the ideology of the Justices on the Court. As with our analysis of the impact of subject area on choice of deference regime, we do not claim that our analysis in this section is exhaustive. There are certainly other variables at play in determining agency win rates and certainly numerous complex interactions exist both among the variables mentioned here and between these variables and others that we do not explore. Still the analysis that we provide does offer some indication of when agencies are likely to win at the Court, while also pointing towards areas for potential future inquiry.

a. Influence of Deference Regime. The win rates for the various deference regimes along the continuum of deference lay out in a rather predictable manner. Unsurprisingly, and in line with its presumption against the agency interpretation, the regime with the lowest win rate is anti-deference. This is the only deference regime with a win rate lower than $50 \%$ and the only deference regime with a win rate lower than the average win rate across deference regimes. Indeed, every other deference regime produces win rates above the average, indicating that, on the whole, invocation of a regime by the Court bodes well for the agency.

There is, however, variation in the win rates produced by deference regimes. On the high end of the spectrum, the rare invocation of either Seminole Rock deference or Curtiss-Wright deference virtually assures the agency a legal victory. Invocation of Skidmore, Beth Israel, Chevron, or consultative deference offers more modest benefits, with win rates for all four deference regimes hovering around $75 \%$ (still a pretty good record).

Further unpacking the data, the precise win rates of Skidmore, Beth Israel, Chevron, and consultative deference prove to be illuminating. Justice Scalia's concern about the Skidmore standard for weighing agency interpretations, which 
affords them "respect proportional to [their] power to persuade," is that it allows more judicial discretion and permits less judicial deference to agency interpretations than the Chevron test. Our data indicate that this may be true, but only marginally so. The agency win rate in Chevron cases (76.2\%) is less than three percentage points higher than the agency win rate in Skidmore cases $(73.5 \%)$. Both Skidmore and Chevron cases display a higher win rate than the agency enjoys without deference-a result consistent with Kristin Hickman and Matthew Krueger's study of agency win rates when courts of appeals apply Skidmore. ${ }^{179}$ Thus, based upon the data thus far assembled, Justice Scalia ought to be less concerned that his colleagues are using Skidmore to impose their will upon agencies-and more concerned that they (and he!) are applying Skidmore and Chevron without any rhyme or reason.

Moreover, as noted above, many of the cases in which the Court utilized consultative deference were Skidmore-eligible and differed only from Skidmore cases in the Court's failure to invoke that case's name or its standard for weighing evidence (hence the friendly appellation Skidmore-Lite). Interestingly, though, the agency win rate for consultative deference was over seven percentage points greater than the win rate for Skidmore cases and over four percentage points greater than the win rate for Chevron cases. The Skidmore-Lite cases, it turns out, might have been better nicknamed Skidmore-Heavy. Indeed, the Court's failure in consultative deference cases to explicitly state that it is deferring to the agency, and failure to invoke any standard by which the agency inputs on which it is relying are weighed, does not seem to have undermined its ability to learn from the agency's submissions and side with the agency when the legal materials do not strongly press the Justices toward a contrary construction.

There is a selection bias that contributes to the high agency win rate in consultative deference cases. In most of those cases, the agency's interpretation was presented in an amicus brief filed by the Solicitor General, often solicited by the Court. We should expect higher agency win rates in those cases for three reasons: the Court is signaling that it is uncertain and needs help, the agency view comes only after the Solicitor General's lawyers have seen briefing and decisions from the lower courts, and the Solicitor General can present the agency's (or his) views as a neutral observer rather than as a party to the case. The most important lesson of the consultative deference cases-and there are a lot of them-is that the Supreme Court rewards agencies when they provide

179. Hickman \& Krueger, supra note 32, at 1275-79 (finding an agency win rate of $60.4 \%$ among courts of appeals decisions applying Skidmore - what the authors consider a higher-than-ordinary win rate, but one lower than the agency win rate when courts of appeals apply Chevron). It is notable that Hickman and Krueger's study of Skidmore win rates among courts of appeals judges is much lower than our study of Skidmore's win rates at the Supreme Court level. In our view, the best explanation of this variance is that the agency or the Solicitor General presented its full panoply of Skidmore reasoning only at the Supreme Court level, with a much less impressive case-or none at all-at the court of appeals level. 
useful information about the history of the statutory scheme, real-world facts and context, and the consequences of different interpretations for the effectuation of complicated congressional purposes.

Finally, note that the win rate for cases where no deference regime is invoked is slightly less than the overall win rate, $66.0 \%$ as compared to $68.8 \%$. This is consistent with, but by no means proves, the notion that invocation of a deference regime offers a certain boost to the agency. But it also confirms that even when the Court is engaging in ad hoc judicial reasoning, which it does in $53.6 \%$ of all cases, the agency, on average, fairs very well. Indeed, it offers strong support for the conclusion that even when it employs standard methods of statutory interpretation, the Court is predisposed to find the agency in the right, for the reasons suggested above. ${ }^{180}$

b. Influence of Subject Matter. As with disaggregation by deference regime, disaggregation by subject area reveals, first and foremost, that a bias towards upholding agency interpretations prevails at the Supreme Court level. In none of the twenty-three subject areas was the agency win rate below 50\%. Indeed, it was above $60 \%$ in twenty subject areas and above the average win rate of $68.8 \%$ in fourteen subject areas.

Still, there was wide variation in the win rates among subject areas. One way to make sense of this variation is to think of win rates as a function of the comparative institutional advantage of the Court vis-à-vis the relevant agencies in particular subject areas. Table 16 groups the twenty-three individual subject areas into six broader subject groups: foreign affairs and national security; technical or economic regulations; procedural rules; socio-economic regulations; criminal law; and federal governance. Across these groups, the Court's institutional competence is not uniform. In the area of foreign affairs and national security, where interpretations are often based upon sensitive political calculations, the Justices usually see themselves at an institutional disadvantage in comparison to the executive branch. Likewise for the field of technical and economic regulations, agency expertise leaves the Justices less equipped to understand the issues than specialized agencies. In the area of procedural rules, in contrast, the Justices know as much or almost as much as the agency, usually the Solicitor General's Office, even when the issues are highly technical. Still, it is only in the areas of socio-economic regulation, criminal law, and federal governance, where the issues are less likely to be highly technical and the Justices see themselves as knowledgeable and friendly critics of agency interpretations, that the Court can claim a real (or perceived) institutional advantage.

To make this more concrete, contrast Gonzales v. Oregon, ${ }^{181}$ which is exemplary of cases in the socio-economic regulations category, with a typical tax treaty case, which is exemplary of cases in the technical or economic regulations category. The issues in the Oregon Aid-in-Dying Case-determining the

180. See supra text accompanying notes 134-36.

181. 546 U.S. 243 (2006). 
Table 16. The Effect of Subject Area on Agency Win Rates ${ }^{182}$

\begin{tabular}{|l|l|l|}
\hline & \multicolumn{2}{|c|}{ Specific Subject Area Win Rates } \\
\hline $\begin{array}{c}\text { Broad Subject } \\
\text { Area Grouping }\end{array}$ & $\begin{array}{c}\text { Agency Win Rate Less than } \\
\text { the Overall Win Rate of } \\
\mathbf{6 8 . 8 \%}\end{array}$ & $\begin{array}{c}\text { Agency Win Rate Greater } \\
\text { than the Overall Win Rate of } \\
\mathbf{6 8 . 8 \%}\end{array}$ \\
\hline $\begin{array}{l}\text { Foreign Affairs and } \\
\text { National Security }\end{array}$ & $\begin{array}{l}\text { Immigration (67.7\%) } \\
\begin{array}{l}\text { Technical or } \\
\text { Economic } \\
\text { Regulations }\end{array}\end{array}$ & $\begin{array}{l}\text { Foreign Affairs and National } \\
\text { Security (78.5\%) }\end{array}$ \\
\hline $\begin{array}{l}\text { Environment (68.4\%) } \\
\text { Regulations }\end{array}$ & $\begin{array}{l}\text { Bankruptcy (75.0\%) } \\
\text { Business Regulation (77.1\%) } \\
\text { Tax (75.7\%) } \\
\text { Transportation (78.6\%) } \\
\text { Intellectual Property (88.2\%) } \\
\text { Pensions (82.5\%) } \\
\text { Energy (93.3\%) }\end{array}$ \\
\hline Procedural Rules & & Federal Procedure (71.6\%) \\
\hline $\begin{array}{l}\text { Federal } \\
\text { Governance }\end{array}$ & Indian Affairs (51.6\%) & Entitlement Programs (71.9\%) \\
Labor (65.5\%) & Criminal Law (62.3\%) & \\
\hline
\end{tabular}

extent of the statutory delegation, applying the Controlled Substances Act (CSA) to aid-in-dying, and contemplating the federalism and individual rights implications of preemption-involve moral and political considerations about which the Justices know (or think they know) just as much or almost as much as the Attorney General and about which they believe they have little to learn from his Directive and the underlying memoranda. ${ }^{183}$ In contrast, the issues in an international tax treaty case-the meaning of textual provisions negotiated with countries having a different legal tradition from ours, the context in which the treaty was negotiated, and the foreign affairs and commercial consequences of different interpretations-involve difficult technical, economic, and political judgments about which the Justices do not know nearly as much as the State

182. Table 16 excludes subject areas where there were fewer than ten cases because the small sample size skews the results. Also, in order to present a more accurate picture of the Court's practice, Table 16 presents the win rate for all ninety-three cases where foreign affairs and national security were at issue, instead of the win rate for only those six cases where foreign affairs and national security was the dominant subject area.

183. The typical federal jurisdiction issue, to take something from the intermediate category, likewise involves legal, institutional, and practical considerations about which the Justices often do have strong opinions, know as much as the Solicitor General, and believe they have little to learn from his submissions. 
Department and the Solicitor General and about which they believe they have a lot to learn from the executive branch submissions.

A complementary way of thinking about our findings in Table 16 focuses on the role of statutory values and the relative intensity of (judicial) preferences to explain different agency success rates. In the area of technical and economic regulations, the congressional goal is usually instrumental efficiency, and the role of the agency is to implement technical commands in a way that advances Congress's economic or national-security purposes. Pension and tax law, environmental law, and intellectual property law all have this feature. Given their training, aptitude, and institutional constraints, the Justices not only feel they have little to add to this normative enterprise, but whatever views they have on the merits are not intensely held. Although critics often claim that agencies pursue misguided policies that undermine statutory goals, it is hard for the Justices to figure out who is right about that - and most of them do not have strong feelings one way or the other about these policy debates. Chevron itself, which involved a judgment call regarding the Clean Air Act's trade-off between air quality and reasonable cost, boiled down to precisely this normative vacuum: Justices voted without regard to their political preferences, which were thinly implicated in the case, if at all, and were open to the EPA's arguments and judgment. ${ }^{184}$

In contrast, socio-economic regulations, criminal law, and federal governance laws tend to involve statutes whose congressional goal is substantially noninstrumental or is instrumental in a broader socio-political way. Thus, the CSA, at issue in Oregon, embodied values that are both punitive (non-instrumental) and cultural-political (cleanse the community of polluting drugs). As applied to the Oregon Death-with-Dignity Law, the CSA also raised moral questions about aid-in-dying and political philosophy questions about the allocation of decisionmaking authority in our federalism. These are not only questions about which the Court has less to learn from the Attorney General but also ones about which the Justices' own preferences are quite intense or strongly held. The Ashcroft Directive and its supporting memoranda failed to demonstrate a comparative institutional advantage in grappling with these moral and political issues, but even a better-reasoned Directive would not have generated much deference within the Supreme Court.

In short, our hypothesis is that the Court is more likely to side with the agency in areas where the Court has a real (or perceived) institutional disadvan-

184. Evidence for this abounds in Justice Blackmun's Notes for the Chevron Conference. Blackmun Papers, supra note 6, Box 397, Folder 7. The Conference vote was 4-3 to reverse the D.C. Circuit and uphold the EPA. Justice Blackmun's Notes place little question marks by the "reverse" votes of Justices White, Powell, and Stevens, indicating that their votes were tentative at best. "When I am so confused, I go with the agency," Justice Stevens confessed. Justice O'Connor voted to affirm the D.C. Circuit but candidly indicated that she found the bubble concept very attractive, especially in light of the "suffering" of private industries. After Justice O'Connor recused herself, Chief Justice Burger and Justice Brennan-the most unlikely ideological bedfellows-changed their minds and joined Justice Stevens's opinion allowing the bubble concept. It is impossible to imagine this level of honest disagreement, tentativeness, and vote-changing in the Oregon Aid-in-Dying Case. 
tage and where Justices do not have strongly held views, while the Court is more likely to overturn the agency in areas where the Court has a real (or perceived) institutional advantage and where the views of the Justices are particularly strong. Our data do not prove the validity of this hypothesis but are generally consistent with it, with some exceptions (for example, the win rate for entitlement programs is above average). On the whole, though, the hypothesis fits the data well enough to indicate that comparative institutional competence and intensity of the Court's opinions are at least somewhat predictive of agency win rates.

c. Influence of Open Process. Agency interpretations reached through an open process with input from public would, we hypothesized, possess greater legitimacy than those developed without public input and, therefore, might be more frequently upheld by the Court. Our data unsettle this assumption. Almost one-third of the agency interpretations in our sample $(29.1 \%)$ were created through an official, open process with input from the public, through either informal (usually notice-and-comment) legislative rulemaking $(21.5 \%)$ or formal adjudication (7.7\%). As Table 17 indicates, although legislative rules enjoyed an above average win rate of $72.5 \%$, formal adjudications won at the rate of $65.4 \%$, which is below the average win rate of $68.8 \%$ and also the informal interpretation win rate of $68.1 \%$.

We offer three possible explanations for the markedly higher win rates for agency interpretations embodied in rulemaking as opposed to adjudications. First, we suspect that an agency following notice-and-comment rulemaking procedures, pursuant to congressional authorization, might produce legal directives that are perceived of as relatively more legitimate than the typically ad hoc directives issued in administrative adjudications. ${ }^{185}$ Adjudications may lose a process point or two because they do not reflect wide public input. Second, there may be a selection effect at work. Because legislative rules tend to affect more people than adjudicatory directives, there might be more institutional resources to fight agency interpretations, even solidly based ones, all the way to the Supreme Court. Thus, legislative rules that reach the Court might be relatively stronger than adjudicatory directives, as a legal matter. Finally, the variation in win rates might be the product of the composition of cases. Almost half of the formal adjudications reaching the Court come in labor cases (primarily orders from the NLRB and the Federal Labor Relations Authority). As detailed above, labor is an area where the Court feels that it has comparative institutional competence vis-à-vis the agency, which might be driving the lower agency win rates.

Yet even if these hypotheses hold, the win rates for informal interpretations may still problematize the notion that higher win rates attach to agency interpretations born of open processes. As Table 18, infra, indicates, informal agency

185. This argument is presented in Henry S. Richardson, Democratic Autonomy: Public ReasonING ABOUt THE ENDS OF PoLICY 219-22 (2002). 
Table 17. Format of Agency Interpretation and Agency Win Rate

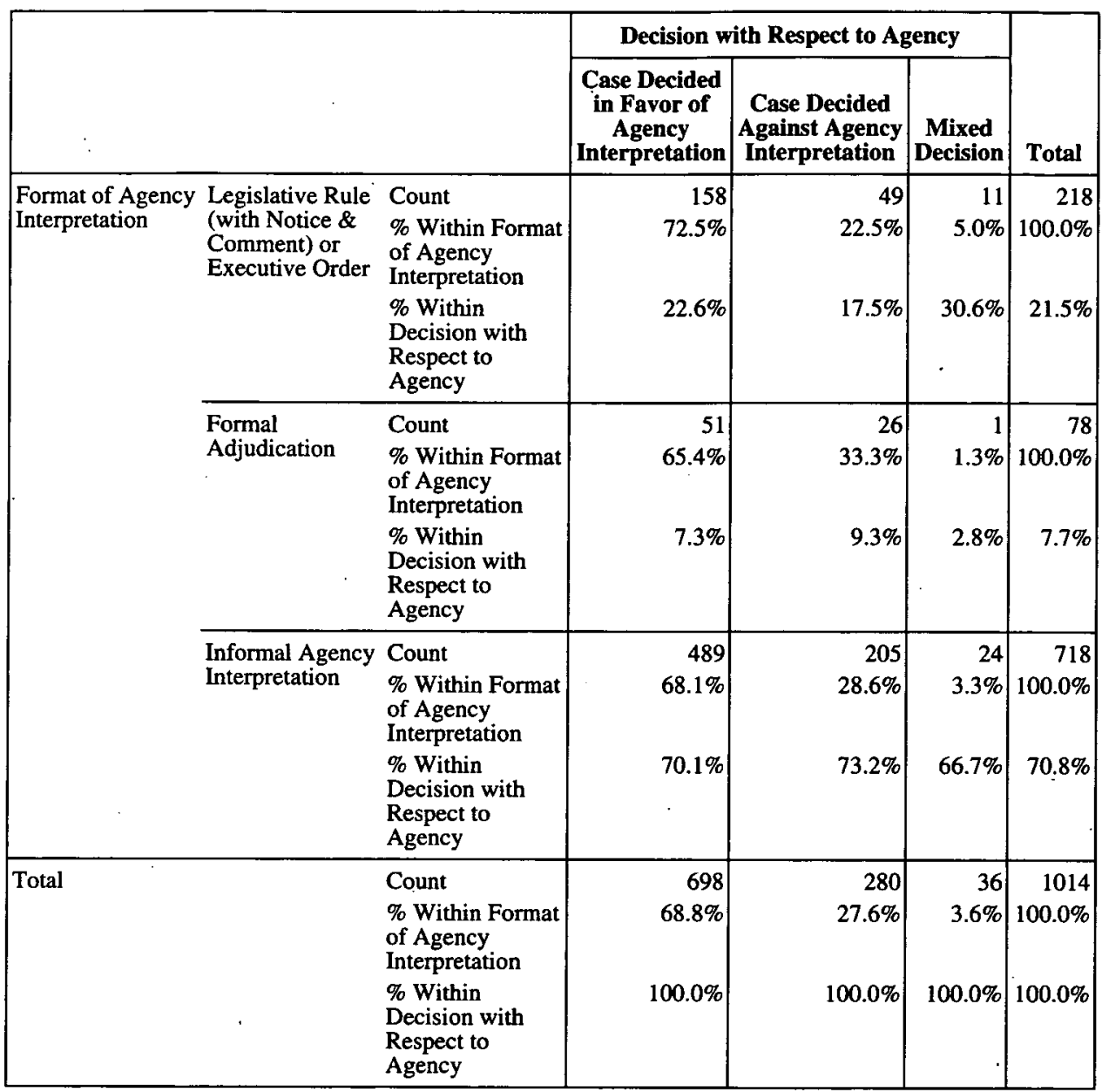

interpretations in the form of interpretive rules or guidances, agency manuals or letters, or arguments in amicus briefs are all upheld at a rate higher than the average agency win rate. What's more, the win rate for interpretive rules and guidances and amicus briefs is actually higher than the win rate for legislative rules. Indeed, it is only agency litigating positions, which suffer from the appearance of having been made for the moment, that win at a rate less than the average win rate. It follows, then, that there is not a tight fit between the process by which an agency interpretation is created and the likelihood that that interpretation will win.

d. Agency Consistency over Time. There is another process variable that plays a significant role in predicting agency success: consistency in the agency interpretation over time. Table 19 reports our data. The agency win rate for longstanding and relatively stable interpretations is an impressive $73.2 \%$. This 
Table 18. Informal Agency Interpretations and Agency Win Rate

\begin{tabular}{|c|c|c|c|c|c|c|}
\hline & & \multicolumn{3}{|c|}{ Decision with Respect to Agency } & \multirow[b]{2}{*}{ Total } \\
\hline & & & $\begin{array}{c}\text { Case Decided } \\
\text { in Favor of } \\
\text { Agency } \\
\text { Interpretation }\end{array}$ & $\begin{array}{c}\text { Case Decided } \\
\text { Against } \\
\text { Agency } \\
\text { Interpretation }\end{array}$ & $\begin{array}{c}\text { Mixed } \\
\text { Decision }\end{array}$ & \\
\hline \multirow{12}{*}{$\begin{array}{l}\text { Format of } \\
\text { Interpretation, if } \\
\text { Informal }\end{array}$} & \multirow[t]{3}{*}{ Agency Litigating Position } & Count & 204 & 108 & 11 & \\
\hline & & $\begin{array}{l}\text { \% Within Format of } \\
\text { Interpretation, if } \\
\text { Informal }\end{array}$ & $63.2 \%$ & $33.4 \%$ & $3.4 \%$ & $100.0 \%$ \\
\hline & & $\begin{array}{l}\text { \% Within Decision } \\
\text { with Respect to } \\
\text { Agency }\end{array}$ & $41.0 \%$ & $52.2 \%$ & $45.8 \%$ & $44.4 \%$ \\
\hline & \multirow[t]{3}{*}{ Interpretive Rule/Guidance } & Count & 38 & 13 & 1 & \\
\hline & & $\begin{array}{l}\text { \% Within Format of } \\
\text { Interpretation, if } \\
\text { Informal }\end{array}$ & $73.1 \%$ & $25.0 \%$ & $1.9 \%$ & $100.0 \%$ \\
\hline & & $\begin{array}{l}\% \text { Within Decision } \\
\text { with Respect to } \\
\text { Agency }\end{array}$ & $7.6 \%$ & $6.3 \%$ & $4.2 \%$ & $7.1 \%$ \\
\hline & \multirow{3}{*}{ Agency Manual or Letter } & Count & 27 & 11 & 1 & \\
\hline & & $\begin{array}{l}\text { \% Within Format of } \\
\text { Interpretation, if } \\
\text { Informal }\end{array}$ & $69.2 \%$ & $28.2 \%$ & $2.6 \%$ & $100.0 \%$ \\
\hline & & $\begin{array}{l}\text { \% Within Decision } \\
\text { with Respect to } \\
\text { Agency }\end{array}$ & $5.4 \%$ & $5.3 \%$ & $4.2 \%$ & $5.4 \%$ \\
\hline & \multirow{3}{*}{$\begin{array}{l}\text { Agency or Solicitor } \\
\text { General Amicus Brief }\end{array}$} & Count & 228 & 75 & 11 & 314 \\
\hline & & $\begin{array}{l}\text { \% Within Format of } \\
\text { Interpretation, if } \\
\text { Informal }\end{array}$ & $72.6 \%$ & $23.9 \%$ & $3.5 \%$ & $100.0 \%$ \\
\hline & & $\begin{array}{l}\text { \% Within Decision } \\
\text { with Respect to } \\
\text { Agency }\end{array}$ & $45.9 \%$ & $36.2 \%$ & $45.8 \%$ & $43.1 \%$ \\
\hline \multirow[t]{3}{*}{ Total } & & Count & 497 & 207 & 24 & 728 \\
\hline & & $\begin{array}{l}\text { \% Within Format of } \\
\text { Interpretation, if } \\
\text { Informal }\end{array}$ & $68.3 \%$ & $28.4 \%$ & $3.3 \%$ & $100.0 \%$ \\
\hline & & $\begin{array}{l}\text { \% Within Decision } \\
\text { with Respect to } \\
\text { Agency }\end{array}$ & $100.0 \%$ & $100.0 \%$ & $100.0 \%$ & $100.0 \%$ \\
\hline
\end{tabular}

is both higher than the average win rate of $68.8 \%$ and the win rates for recent and evolving agency positions, $66.9 \%$ and $60.5 \%$, respectively. Indeed, the association between continuity and agency win rate displayed by the data-with longstanding interpretations having the highest win rate, followed by recent interpretations, followed by evolving interpretations-indicates that the Court has a preference for supporting interpretations that are stable, and ideally, ones that have been stable for some time. We also crosstabulated the consistency criterion with the delegation one. When the agency's interpretation is Chevroneligible both because it is pursuant to a congressional lawmaking delegation and because it is longstanding, the agency win rate is $81.1 \%$, among the highest we found. In contrast, the win rates for recent or evolving interpretations that were made pursuant to a congressional lawmaking delegation are $64.2 \%$ and $57.7 \%$, respectively, both of which are less than the overall win rate of $68.8 \%$. Thus, it is fair to say that agency consistency yields an extra win-rate bump in cases that 
Table 19. Continuity of Agency Position and Agency Win Rate

\begin{tabular}{|c|c|c|c|c|c|c|}
\hline & \multicolumn{3}{|c|}{ Decision with Respect to Agency } & \multirow[b]{2}{*}{ Total } \\
\hline & & & $\begin{array}{c}\text { Case Decided } \\
\text { in Favor of } \\
\text { Agency } \\
\text { Interpretation }\end{array}$ & $\begin{array}{l}\text { Case Decided } \\
\text { Against } \\
\text { Agency } \\
\text { Interpretation }\end{array}$ & $\begin{array}{c}\text { Mixed } \\
\text { Decision }\end{array}$ & \\
\hline \multirow{10}{*}{$\begin{array}{l}\text { Continuity of } \\
\text { Agency } \\
\text { Position }\end{array}$} & \multirow{4}{*}{$\begin{array}{l}\text { Longstanding } \\
\text { and Fairly } \\
\text { Stable }\end{array}$} & Count & 260 & 84 & 11 & 355 \\
\hline & & $\begin{array}{l}\text { \% Within Continuity of } \\
\text { Agency Position }\end{array}$ & $73.2 \%$ & $23.7 \%$ & $3.1 \%$ & $100.0 \%$ \\
\hline & & $\begin{array}{l}\text { \% Within Decision } \\
\text { with Respect to Agency }\end{array}$ & $37.2 \%$ & $30.0 \%$ & $30.6 \%$ & $35.0 \%$ \\
\hline & & $\%$ of Total & $25.6 \%$ & $8.3 \%$ & $1.1 \%$ & $35.0 \%$ \\
\hline & \multirow[t]{3}{*}{ Evolving } & $\begin{array}{l}\text { Count } \\
\text { \% Within Continuity of } \\
\text { Agency Position }\end{array}$ & $\begin{array}{r}26 \\
60.5 \%\end{array}$ & $\begin{array}{r}17 \\
39.5 \%\end{array}$ & $\begin{array}{r}0 \\
.0 \%\end{array}$ & $\begin{array}{r}43 \\
100.0 \%\end{array}$ \\
\hline & & $\begin{array}{l}\% \text { Within Decision } \\
\text { with Respect to Agency }\end{array}$ & $3.7 \%$ & $6.1 \%$ & $.0 \%$ & $4.2 \%$ \\
\hline & & $\%$ of Total & $2.6 \%$ & $1.7 \%$ & $.0 \%$ & $4.2 \%$ \\
\hline & \multirow[t]{3}{*}{ Recent } & $\begin{array}{l}\text { Count } \\
\text { \% Within Continuity of } \\
\text { Agency Position }\end{array}$ & $\begin{array}{r}412 \\
66.9 \%\end{array}$ & $\begin{array}{r}179 \\
29.1 \%\end{array}$ & $\begin{array}{r}25 \\
4.1 \%\end{array}$ & $\begin{array}{r}616 \\
100.0 \%\end{array}$ \\
\hline & & $\begin{array}{l}\% \text { Within Decision } \\
\text { with Respect to Agency }\end{array}$ & $59.0 \%$ & $63.9 \%$ & $69.4 \%$ & $60.7 \%$ \\
\hline & & $\%$ of Total & $40.6 \%$ & $17.7 \%$ & $2.5 \%$ & $60.7 \%$ \\
\hline \multirow[t]{4}{*}{ Total } & & Count & 698 & 280 & 36 & 1014 \\
\hline & & $\begin{array}{l}\% \text { Within Continuity of } \\
\text { Agency Position }\end{array}$ & $68.8 \%$ & $27.6 \%$ & $3.6 \%$ & $100.0 \%$ \\
\hline & & $\begin{array}{l}\text { \% Within Decision } \\
\text { with Respect to Agency }\end{array}$ & $100.0 \%$ & $100.0 \%$ & $100.0 \%$ & $100.0 \%$ \\
\hline & & $\%$ of Total & $68.8 \%$ & $27.6 \%$ & $3.6 \%$ & $100.0 \%$ \\
\hline
\end{tabular}

are Chevron-eligible.

The foregoing analysis stands the Chevron Revolution on its head. Chevron famously ruled that the EPA's change in interpretation was not relevant in judging the reasonableness of its interpretation, ${ }^{186}$ and Justice Scalia has touted agency flexibility to abandon prior interpretations as the chief legal feature of the Chevron Revolution. ${ }^{187}$ Indeed, agency consistency was a deferenceenhancing feature of the supposedly obsolete or subordinated Skidmore regime. ${ }^{188}$ Yet we found agency consistency to be positively associated with win rates not only in the cases where the Court accorded Skidmore or consultative (Skidmore-Lite) deference, but also for the cases where the court invoked Chevron deference. In fact, agency consistency was positively associated with

186. Chevron U.S.A., Inc. v. Natural Res. Def. Council, 467 U.S. 837, 853-58, 863-66 (1984).

187. See United States v. Mead Corp., 533 U.S. 218, 247-50 (2001) (Scalia, J., dissenting).

188. Yoav Dotan, Making Consistency Consistent, 57 ADMIN. L. Rev. 995, 1000-01 (2005). Cf. Hickman \& Krueger, supra note 32, at 1286-88 (finding that courts of appeals applying Skidmore gave less emphasis to consistent agency policy than the authors expected). 
win rates across all deference regimes.

The most obvious explanation for this arresting phenomenon is that agency consistency has a number of virtues that Justice Scalia and many scholars have under-appreciated. A consistent agency interpretation is one that is relatively more likely to have generated private as well as public reliance, usually bears the legitimacy of support across politically different administrations, and has the practical advantage of knowability, as ambiguities get ironed out over time. Flip the analysis and the virtues of longevity may be even more apparent. An agency interpretation that departs from a previously established agency understanding is more likely to be arbitrary in several senses: compared with a longstanding interpretation, a new construction is more likely to unsettle reliance interests, is more likely to reflect a partisan political judgment not carefully moored to carrying out Congress's statutory purposes, and is more likely to raise new interpretive difficulties for regulated interests. These risks are illustrated by the Ashcroft Directive overridden in Oregon. The Attorney General's novel interpretation would have reversed a decade's worth of popular deliberation in Oregon, which had rested on the assumption that the CSA did not bar death-withdignity; was a partisan and controversial political judgment; and opened up the possibility of further expansions of criminal liability by the Attorney General.

To be sure, the Supreme Court deferred to the agency volte-face in Chevron, but the new agency interpretation there had come only after notice-andcomment rulemaking. The process contrast between Chevron and Oregon was telling: in the former case, a political judgment had come only after a process that was open to public participation and scrutiny, that considered comments from a variety of perspectives, and that included agency responses to arguments offered by the public. In Oregon, the Attorney General's failure to involve the agency (HHS) charged with medical determinations under the CSA was a further process defect that suggested the possibility of arbitrariness.

e. Statutory Plain Meaning. The Supreme Court in the period from Chevron to Hamdan has emphasized text-based sources for statutory interpretation more often than previous Courts. (Justices Scalia and Thomas rarely consult legislative history.) We thought that such a Court would generally, and perhaps overwhelmingly, defer to agencies when the Justices failed to find a statutory plain meaning. Justice Scalia's approach to agency deference all but demands this: he would apply Chevron very broadly to allow agencies to set rules according to their own conception of the best policy in cases where the statute has no plain meaning. But even under Justice Stevens's approach, which examines legislative history as well, we should expect that agencies would get something of a statistical bounce if the Court finds no plain meaning.

The data provide no support for this hypothesis, however. In the 414 cases where the Court found the statutory text at least somewhat ambiguous, the agency prevailed $69.1 \%$ of the time-virtually the same as the agency win rate of $68.7 \%$ when the Court found the statute had a plain meaning. The latter 
figure reflects the conventional wisdom that agencies and the Solicitor General do a very impressive job of anticipating or influencing the Court's textual analysis of regulatory statutes. The former figure probably means that other factors-legislative history, precedent, and substantive canons-might trump an agency interpretation even when the statutory text does not.

A deeper exploration of the Court's plain-meaning jurisprudence suggests a more robust variable. Text-based interpretation assumes an audience: a term has a plain meaning if, as Justice Scalia once put it, you can use it that way "at a cocktail party without having people look at you funny." ${ }^{189}$ An implication of cocktail-party textualism is that "plain" meaning is a social product, for it will depend on what kind of crowd the Justices party with. If you announce at a Catholic parish cocktail party that the Attorney General has just barred the use of drugs for "assisted suicide" under his authority to regulate the use of listed drugs in the "public interest," no one will look at you funny; some will shake your hand or hug you. In contrast, such an announcement at an ACLU cocktail party would bring funny looks, frowns, expressions of alarm, and suggestions that the proper term is "death with dignity," not "assisted suicide."

The Justices' performance in the Oregon Aid-in-Dying Case is consistent with this social (cocktail party) understanding of plain meaning. In his dissent, Justice Scalia found a plain meaning that supported the Attorney General, a conclusion the majority rejected in favor of its reading of the statute. The willingness of the dissenters to find a plain meaning is a product of a normative rather than a neutral analysis of the statutory text, and the same factor, normative baseline, best explains why the majority Justices did not find a plain meaning. Thus, the rhetoric and intensity of the dissenting opinion suggest a sympathy to the pro-life philosophy of many religious fundamentalists, who believe that what they (and Justice Scalia's dissent) call "assisted suicide" is a form of murder and is morally reprehensible. In contrast, the majority demonstrated the same moderately pro-choice philosophy that the five Glucksberg concurring Justices (who were five of the six in the Oregon majority) argued for: there is no general constitutional "right to die," but Americans do have a liberty interest in setting some parameters on the conditions of their own deaths-what the Oregon statute calls "death with dignity." suicide" viewpoint of the Oregon dissenters made it hard for them to see the CSA text as anything other than a ban against doctors using drugs to murder people. The "death with dignity" viewpoint of the majority made it hard for them to believe that Congress in 1971 wanted the Attorney General to have the

189. Johnson v. United States, 529 U.S. 694, 718 (2000) (Scalia, J., dissenting).

190. Note that Justice Kennedy, the author of Oregon, joined the Chief Justice's opinion for the Court in Glucksberg, which rejected a right to die in very broad language. Washington v. Glucksberg, 521 U.S. 702 (1997). The other five Justices in the Oregon majority wrote concurring opinions open to a constitutional right to die under certain circumstances. See id. at 736 (O'Connor, J., concurring); id. at 738 (Stevens, J., concurring in the judgment); id. at 752 (Souter, J., concurring in the judgment); id. at 789 (Ginsburg, J., concurring in the judgment); id. (Breyer, J., concurring in the judgment). 
power to cut off an important state experiment in allowing the regulated use of drugs to hasten an impending demise.

f. Ideological Voting. The hypothesis suggested by our thought experiment involving cocktail-party textualism is that the willingness of a Justice to find a plain meaning that supports or rejects an agency interpretation is influenced by the Justice's normative community and, for ideologically charged issues, is not determined entirely by a neutral analysis of the statutory text.

To provide an initial test of this hypothesis, we coded the agency interpretation as "liberal" or "conservative" in each of the 1014 statutory cases between Chevron and Hamdan. ${ }^{191}$ We then coded for whether the Court upheld or struck down the interpretation in each case, and how each Justice voted in the case. We used this information to calculate three agency-agreement rates for each of the seventeen Justices who sat on the Court during this period. First, we calculated an overall agreement rate, which indicated how often the judge voted in the majority or concurred when an agency interpretation was upheld or voted in the dissent when an agency interpretation was struck down. Second, we calculated an agreement rate for liberal agency interpretations, which indicated how often the judge voted in the majority or concurred when a liberal agency interpretation was upheld or voted in the dissent when a liberal agency interpretation was struck down. Finally, we calculated an agreement rate for conservative agency interpretations, which indicated how often the judge voted in the majority or concurred when a conservative agency interpretation was upheld or voted in the dissent when a conservative agency interpretation was struck down. Using the appointing President as a metric for whether a judge was liberal or conservative, ${ }^{192}$ we were then able to determine whether liberal judges were more likely to agree with liberal agency interpretations than conservative judges, and vice versa.

As Table 20 on the following page indicates, the norm across Justices is to support the agency interpretation more often than not. The mean agency agreement rate was $67.0 \%$ and the median rate was $68.6 \%$, a figure nearly identical to the overall agency win rate of $68.8 \%$. Indeed, no Justice displayed an overall agency agreement rate of less than $52.6 \%$. That said, the Justices do exhibit

191. We followed conventional understandings of these terms. So "liberal" agency interpretations would be those which favored victim claims in civil rights cases (except for affirmative action claims), employee claims in labor and pension cases, taxpayer claims in tax cases, debtor claims in bankruptcy cases, defendant claims in criminal cases, people seeking benefits in entitlement cases, Native American claims in Indian cases, immigrants' claims in immigration cases, and consumer or consumerprotecting claims in business regulation, telecommunications, and transportation cases. "Conservative" interpretations are usually the flip side of liberal interpretations.

192. We deviate from this rule only in the labeling of William Brennan who, although appointed by Republican Dwight Eisenhower, was a known Democrat. One of us would be inclined also to deviate for John Paul Stevens, a former plaintiffs' antitrust attorney elevated to the Court by President Ford (and his respected Attorney General Edward Levi), in a rare appointment that was apparently based solely on merit. 
Table 20. Agreement with Agency Interpretations, by Justice (Sorted from Highest Agreement Rate to Lowest)

\begin{tabular}{|c|c|c|c|c|}
\hline Justice \& Tenure & $\begin{array}{c}\text { Justice } \\
\text { Ideology }\end{array}$ & $\begin{array}{l}\text { Overall Agency } \\
\text { Agreement } \\
\text { Rate }\end{array}$ & $\begin{array}{c}\text { Agreement } \\
\text { Rate for } \\
\text { Liberal } \\
\text { Interpretations }\end{array}$ & $\begin{array}{c}\text { Agreement } \\
\text { Rate for } \\
\text { Conservative } \\
\text { Interpretations }\end{array}$ \\
\hline Warren Burger (1969-86) & Conservative & $81.3 \%$ & $75.9 \%$ & $87.0 \%$ \\
\hline Byron White (1962-93) & Liberal & $74.0 \%$ & $71.9 \%$ & $76.3 \%$ \\
\hline Lewis Powell (1971-87) & Conservative & $72.7 \%$ & $73.4 \%$ & $73.0 \%$ \\
\hline Stephen Breyer (1994-) & Liberal & $72.0 \%$ & $79.5 \%$ & $64.9 \%$ \\
\hline $\begin{array}{l}\text { William Rehnquist } \\
(1971-2006)\end{array}$ & Conservative & $70.6 \%$ & $59.4 \%$ & $79.1 \%$ \\
\hline $\begin{array}{l}\text { Ruth Bader Ginsburg } \\
(1993-)\end{array}$ & Liberal & $69.5 \%$ & $77.1 \%$ & $61.9 \%$ \\
\hline Anthony Kennedy (1987-) & Conservative & $69.3 \%$ & $61.8 \%$ & $74.0 \%$ \\
\hline David Souter (1990-) & Conservative & $68.7 \%$ & $75.6 \%$ & $62.5 \%$ \\
\hline $\begin{array}{l}\text { Sandra Day O'Connor } \\
(1982-2006)\end{array}$ & Conservative & $68.6 \%$ & $61.5 \%$ & $73.7 \%$ \\
\hline John Roberts* (2005-) & Conservative & $65.8 \%$ & $55.6 \%$ & $67.9 \%$ \\
\hline $\begin{array}{l}\text { Harry Blackmun } \\
(1970-94)\end{array}$ & Conservative & $65.1 \%$ & $80.6 \%$ & $55.3 \%$ \\
\hline Antonin Scalia (1986-) & Conservative & $64.5 \%$ & $53.8 \%$ & $71.6 \%$ \\
\hline Samuel Alito* (2006-) & Conservative & $64.7 \%$ & $75.0 \%$ & $61.5 \%$ \\
\hline Clarence Thomas (1990-) & Conservative & $63.1 \%$ & $46.8 \%$ & $75.8 \%$ \\
\hline $\begin{array}{l}\text { John Paul Stevens } \\
(1975-)\end{array}$ & Conservative & $60.9 \%$ & $79.2 \%$ & $49.6 \%$ \\
\hline $\begin{array}{l}\text { Thurgood Marshall } \\
(1967-91)\end{array}$ & Liberal & $55.6 \%$ & $84.8 \%$ & $38.8 \%$ \\
\hline $\begin{array}{l}\text { William Brennan } \\
(1956-90)\end{array}$ & Liberal & $52.6 \%$ & $81.6 \%$ & $36.7 \%$ \\
\hline
\end{tabular}

*Because Chief Justice Roberts and Justice Alito were appointed to the Court shortly before the end of the time frame for this study, their agreement rates should be interpreted with caution. Chief Justice Roberts's agreement rates are based on the decisions from just thirty-eight cases, and Justice Alito's agreement rates are based on decisions from a mere seventeen cases.

significant variation in their overall agency agreement rates. There is a spread of nearly thirty percentage points between the most deferential Justice, Warren Burger, who agreed with agency interpretations $81.3 \%$ of the time, and the least deferential Justice, William Brennan, who did so only $52.6 \%$ of the time. (Ironically, John Paul Stevens, the author of Chevron, is the third least deferential Justice, consistent with his general philosophy of strictly enforcing congressional expectations and constitutional norms against agencies.)

When agreement rates are broken down by ideology, the variation between Justices becomes greater. There is a spread of nearly forty percentage points between Justice Thomas's liberal agreement rate of $46.8 \%$ (the lowest of all the Justices) and Justice Marshall's liberal agreement rate of $84.8 \%$ (the highest). 
The spread in conservative agreement rates is even greater, ranging over fifty percentage points from Justice Brennan's low of $36: 7 \%$ to Chief Justice Burger's high of $87.0 \%$. (Note that Chief Justice Burger's agreement rate for conservative interpretation is the highest agreement rate of any Justice in any category-liberal, conservative, or overall.) Moreover, the disaggregation of voting rates by ideology reveals dispositions against the agency for the first time. Such anti-agency dispositions are found in Justice Thomas with respect to liberal agency interpretations (which he agrees with only $46.8 \%$ of the time), and with respect to conservative agency interpretations in Justices Stevens, Marshall, and Brennan (which they agree to only $49.6 \%, 38.8 \%$, and $36.7 \%$ of the time, respectively).

Furthermore, calculation of the agreement rate differential for each Justice (that is, the difference between each Justice's agreement rate for liberal interpretations and for conservative interpretations) reveals that, for nearly all of the Justices, voting on issues where agencies had staked out statutory interpretations is an ideological endeavor. The mean agreement-rate differential is $\mathbf{1 8 . 9}$ percentage points, and the median is 14.6 percentage points. Only two Justices (White and Powell) had agreement rate differentials of less than 5\%. The data indicate that, across the board, the ideology of the agency interpretation matters to Justices - and the way it matters depends on the political inclinations of the Justice.

As Table 21 indicates, the direction of the agreement-rate differential matches the ideology of the Justice in eleven of seventeen cases. In other words, liberal Justices are overwhelmingly more likely to agree with liberal agency interpretations than with conservative agency interpretations, and conservative Justices are overwhelmingly more likely to agree with conservative agency interpretations than with liberal agency interpretations. ${ }^{193}$ The exceptions to this rule are easily explained. On the above chart, Justices Blackmun, Stevens, and Souter are labeled conservative because of their appointments by conservative Republican Presidents Nixon, Ford, and George H. W. Bush, respectively. Yet none of these three was as conservative as his appointing President, and each drifted leftward as the Court as a whole became more conservative. For his part, Justice Alito, the most recent George W. Bush appointee, is probably a political conservative, and is likely displaying a bias towards liberal agency interpretations only because of the relatively tiny number of cases he heard (seventeen) during the time frame of our study. We expect his agreement-rate differential to tip towards the conservative side in the future. Finally, Justices White and Powell possess very low agreement-rate differentials, $4.4 \%$ and $0.4 \%$, respec-

193. Our findings here confirm and, we hope, deepen similar findings by previous legal scholars, starting with Revesz, supra note 38, at 1719, 1743-47, who found strong evidence of ideological voting by D.C. judges adjudicating challenges to EPA rules and other actions. See also Kerr, supra note 32, at 37-39 (finding significant evidence of ideological voting in Chevron cases among the courts of appeals); Miles \& Sunstein, supra note 38, at 832-47 (finding significant evidence of ideological voting by Supreme Court Justices in Chevron cases decided between 1994 and 2005). 
Table 21. Agreement Rate Differential (From Highest to Lowest)

\begin{tabular}{|l|l|c|}
\hline \multicolumn{1}{|c|}{ Justice \& Tenure } & Justice Ideology & $\begin{array}{c}\text { Agreement Rate Differential } \dagger \\
\text { (Liberal Rate- } \\
\text { Conservative Rate) }\end{array}$ \\
\hline Thurgood Marshall (1967-91) & Liberal & $46.0 \%$ \\
\hline William Brennan (1956-90) & Liberal & $44.9 \%$ \\
\hline John Paul Stevens (1975-) & Conservative & $29.6 \%$ \\
\hline Clarence Thomas (1990-) & Conservative & $(29.0 \%)$ \\
\hline Harry Blackmun (1970-94) & Conservative & $25.3 \%$ \\
\hline William Rehnquist (1971-2006) & Conservative & $(19.7 \%)$ \\
\hline Antonin Scalia (1986-) & Conservative & $(17.8 \%)$ \\
\hline Ruth Bader Ginsburg (1993-) & Liberal & $15.2 \%$ \\
\hline Stephen Breyer $(1994-)$ & Liberal & $14.6 \%$ \\
\hline Samuel Alito* $(2006-)$ & Conservative & $13.5 \%$ \\
\hline David Souter $(1990-)$ & Conservative & $13.1 \%$ \\
\hline John Roberts* (2005-) & Conservative & $(12.3 \%)$ \\
\hline Anthony Kennedy (1987-) & Conservative & $(12.2 \%)$ \\
\hline Sandra Day O'Connor $(1982-2006)$ & Conservative & $(12.2 \%)$ \\
\hline Warren Burger $(1969-86)$ & Conservative & $(11.1 \%)$ \\
\hline Byron White $(1962-93)$ & Liberal & $(4.4 \%)$ \\
\hline Lewis Powell $(1971-87)$ & Conservative & $0.4 \%$ \\
\hline
\end{tabular}

*Due to the fact that Chief Justice Roberts and Justice Alito were appointed to the Court shortly before the end of the time frame for this study, their agreement rates should be interpreted with caution. Chief Justice Roberts's agreement rates are based on the decisions from just thirty-eight cases, and Justice Alito's agreement rates are based on decisions from a mere seventeen cases.

$\dagger$ Figures in brackets indicate a negative differential; that is, that the Justice had a higher conservative agreement rate.

tively. They are the outliers in a Court dominated by ideological voting.

Indeed, our data strongly suggest that ideology plays a powerful and pervasive role in shaping Supreme Court decisions with regard to agency statutory interpretations. Perhaps the best indicator of whether the agency will win in any given case is the ideological characterization of the agency interpretation and, therefore the ability of that interpretation to persuade Justices of similar ideological leanings on the Court.

\section{Normative Issues: What Should Be the Supreme Court's Approach to AGENCY INTERPRETATIONS OF FEDERAL STATUTES?}

The foregoing empirical analysis demonstrates that the Supreme Court's deference doctrine is complicated as a matter of theory and chaotic as a matter 
of practice. Both the doctrinal complexity and the chaotic application have become more apparent after the Court's decision in Mead, which has generated even more inconsistency and confusion among the lower courts. ${ }^{194}$ Perhaps most of all, our study reveals that the Supreme Court itself is not settled as to what is the correct approach to agency statutory interpretations. At one extreme, Justice Scalia would unify the Court's deference jurisprudence around Chevron, whose two-step framework would be applicable to all interpretations (except litigating positions) that are ratified by an agency head. ${ }^{195}$ At the other extreme, Justice Breyer would unify the Court's deference jurisprudence around Skidmore, with delegated lawmaking authority (the Chevron trigger) being another deference "plus" for the agency. ${ }^{196}$ In the middle, Justices such as Stevens (Hamdan), Kennedy (Oregon), and Souter (Mead) recognize Chevron as a different regime than Skidmore, are comfortable with the doctrines' coexistence, but apply both regimes unpredictably and episodically. All of these Justices apply deference regimes with a discernible ideological slant.

In short, the Supreme Court's deference jurisprudence is a mess.

Should the Justices be concerned? Our intuition, from reading the opinions in 1014 cases and from knowing many of the Justices who authored them, is that the Justices sense the messiness of this jurisprudence but (except for Justice Scalia) are not deeply troubled by it. From their point of view, the Court's inconsistent and confusing deference practice has not disabled the Court from carrying out its primary goals, nor has it created any kind of governance crisis. One normative judgment that can be drawn from our empirical analysis is that the substantially ad hoc approach to agency deference the Court has followed is workable for the Justices. Indeed, the abstract advantages of a more coherent and consistently applied jurisprudence of deference may not be attainable among the current collection of Justices (or perhaps among almost any nine sophisticated jurists with different professional and ideological backgrounds). To the extent the Court does follow an "approach," it is ad hoc: the amount of deference the Justices afford an agency interpretation in a particular case depends on several factors, including congressional delegation of lawmaking authority, agency expertise and consistency, and perhaps other background norms. Our empirical study suggests that, whatever approach the Court says it is following, the Justices will tend to be ad hoc in their actual practice.

Set against the advantages of an ad hoc all-factors-considered approach is

194. On the water-muddying that has accompanied Mead, see Bressman, supra note 32, at 1445; Ronald M. Levin, Mead and the Prospective Exercise of Discretion, 54 ADMIN. L. Rev. 771, 774-76 (2002); Adrian Vermeule, Mead in the Trenches, 71 Geo. WASH. L. REv. 347, 347 (2003).

195. United States v. Mead Corp., 533 U.S. 218, 256-57 (2001) (Scalia, J., dissenting); Nat'l Cable \& Telecomm. Ass'n v. Brand X Internet Servs., 545 U.S. 967, 1015 n.10 (2005) (Scalia, J., dissenting).

196. Barnhart v. Walton, 535 U.S. 212 (2002) (Breyer, J.); Breyer, supra note 17, at 379-81; see also Zuni Pub. Sch. Dist. No. 89 v. Dep't of Educ., 127 S. Ct. 1534 (2007) (Breyer, J.) (applying Chevron, but also emphasizing agency expertise, the agency's longstanding interpretation, and likely congressional reliance). 
Justice Scalia's argument that a bright-line, universal Chevron approach is required by legal and constitutional authorities. Justices Stevens and Breyer reject this argument and believe that the authorities are inconsistent with Justice Scalia's approach. In section III.A, we examine their debate with Justice Scalia through the lens of the Constitution, our legal traditions, and the Administrative Procedure Act (APA). ${ }^{197}$ These formal rule-of-law sources cut too strongly against Justice Scalia's broad reading of Chevron for the Court to follow his lead. These sources are more supportive of an ad hoc all-factors-considered approach (which for convenience we might associate with Justice Breyer) but are most consistent with a simpler version of the deference continuum that preserves a key place for Chevron. ${ }^{198}$

Constitutional and legal sources may not be completely dispositive for at least some judges and commentators, however. In section III.B, we examine more functional justifications that are relevant to the institutional-choice issues involved in agency-deference regimes. In deciding, as a general matter, how deferential courts should be toward agency statutory interpretations, one ought to consider the effect of different regimes on the operation of the rule of law, the utility of decisionmaking by the most competent institutions, and the overall legitimacy of our government. While cutting in more than one direction, these considerations support the normative suggestions set forth in section III.C. Our main suggestion is that the degree of deference the Supreme Court ought to afford an agency interpretation of the statute it is applying ought to be driven by three inquiries: (1) Is the agency interpretation consistent with larger public norms, including constitutional values (Oregon)? (2) Is the agency interpretation pursuant to a congressional delegation of lawmaking authority (Chevron/ $M e a d)$ ? and (3) Is the agency applying special expertise, using its understanding of the facts to carry out congressional purposes (Skidmore)?

We offer some intuitions as to how these variables play out doctrinally, and how they ought to play out, but on the whole, we do not insist on a single doctrinal structure required by our analysis. How to translate these variables into workable doctrine rests upon a judgment that neither we nor other scholars can make with great confidence. It is a matter for the Court itself. If the Justices are more concerned with providing lower courts with clear guidance, they ought to use these variables to simplify and clarify the deference continuum: There should only be three levels of deference, corresponding to Chevron (presumptive deference when an agency is acting pursuant to delegated lawmaking authority), Skidmore (attention to agency factual materials and expert judgment), and Oregon (anti-deference if agency interpretation is inconsistent with broader norms). If the Justices are more concerned with articulating a deference

197. Administrative Procedure Act of 1946, Pub. L. No. 404, 60 Stat. 237 (codified as amended at 5 U.S.C. $\S \S 551-559,701-706(2000))$.

198. Cf. Thomas W. Merrill, The Mead Doctrine: Rules and Standards, Meta-Rules and MetaStandards, 54 ADMIN. L. Rev. 807 (2002) (criticizing Mead for adopting a standards approach that, ex ante, does not provide sufficient guidance for lower courts and other actors). 
approach that reflects their own decisionmaking processes, they ought to use these variables to deepen the approach Justice Breyer has been developing.

We are not optimistic that the Court will be able to deliberate successfully about this calculus of institutional risk or to implement the result of its deliberations. Justice Breyer's approach would then continue to be the best reflection of how the Justices are actually responding to agency inputs in the larger range of agency-interpretation cases. In that event, we also have modest process suggestions the Justices ought to consider, even if they never reach closure as to the precise signal they want to send lower courts, agencies, and the citizenry. Our primary process recommendation is that the Court ought to seek other publicregarding sources of expert input to supplement the Solicitor General's excellent but sometimes biased presentations.

\section{A. FORMALIST ANALYSIS: CONSTITUTIONAL AND STATUTORY AUTHORITY RELEVANT} TO AGENCY DEFERENCE

Justice Scalia's interpretation of Chevron is that its two-step deferential regime ought to govern any statutory interpretation accepted by the commission or officer heading an agency charged with implementing a federal statute. Although Justice Scalia would not defer to litigating positions, he would defer to agency manuals, letters, informal opinions, and amicus briefs, as well as rules and adjudicated orders, so long as they represented the agency head's public and official understanding of the statute. Unfortunately, Justice Scalia has not offered a complete defense of this broad understanding of Chevron. ${ }^{199}$

Justice Breyer and numerous commentators have argued that such an expansive reading of Chevron would be a sharp departure from our constitutional traditions and from the longstanding practice of Congress and the Court. ${ }^{200}$ The "judicial Power" vested with the Supreme Court in Article III entails the authority to declare the law in cases or controversies brought to the Court. The Framers of the Constitution, including both the drafters at Philadelphia and the ratifying delegates in the state conventions, expected federal judges to enforce statutes according to their independent judgment based upon standard canons of statutory construction. As Publius put it in Federalist 78, "[t]he interpretation of the laws is the proper and peculiar province of the courts." 201 Within the original understanding, the "judicial Power" was to announce what a statute

199. The closest Scalia has come has been his dissenting opinion in Mead, 533 U.S. at 239-61. For institutional defenses of an even stronger reading of Chevron, see ADRIAN VERMEULE, JUDGING UNDER UnCertaINTy: InstTtutional Theory OF Legal INTERPRETATION 183-229 (2006); David B. Spence \& Frank Cross, A Public Choice Case for the Administrative State, 89 GEo. L.J. 97, 138-41 (2000).

200. Breyer, supra note 17 , at 379 ("If taken literally, the Court's language [in Chevron] suggests a greater abdication of judicial responsibility than seems wise...."); Cynthia R. Farina, Statutory Interpretation and the Balance of Power in the Administrative State, 89 Colum. L. REv. 452, 499-526 (1989) (criticizing a strong version of Chevron as contrary to original constitutional concerns about excessive delegation and alienation of policymaking from We the People's elected representatives); id. at 472-74 (contrary to the APA as well).

201. The Federalist No. 78 (Alexander Hamilton) (Clinton Rossiter ed., 1961). 
means, not to acquiesce in an agency's interpretation of the law unless it is foreclosed by the statute. ${ }^{202}$ As most famously illustrated in Marbury v. Madison, the Court's authority to say "what the law is" also entails an authority to override the executive. ${ }^{203}$ (As Marbury also illustrates, that authority has been deployed very cautiously by the least dangerous branch. ${ }^{204}$ )

Supporting Justice Scalia's approach, Cass Sunstein argues that the New Deal took this country "beyond Marbury" by effectively recognizing a new principle: "It is emphatically the province of the executive department to say what the law is." ${ }^{205}$ Unfortunately, Sunstein presents little in the way of normative justification for this position, which is not even consistent with the New Deal's experience. The New Deal Congress rejected extreme proposals that would have marginalized judges and denied them their Marbury role of independent judgment in statutory interpretation. ${ }^{206}$ Instead, in 1946 Congress and President Truman enacted the APA. ${ }^{207}$ Section 706 of the APA provides that "the reviewing court shall decide all relevant questions of law" and shall "interpret constitutional and statutory provisions." ${ }^{208}$ The APA requires the court to overturn agency actions, findings, and conclusions that are "arbitrary, capricious, an abuse of discretion, or otherwise not in accordance with law." ${ }^{209}$ And the court must overturn agency actions "in excess of statutory jurisdiction, authority, or limitations, or short of statutory right." ${ }^{10}$ These operative provisions follow the traditional Marbury model. Nowhere does the APA suggest that courts are required to defer to agency interpretations of law. If Chevron is a revolution, it is one seeking to overturn the APA as well as almost two centuries of constitutional understandings.

Has the New Deal made no constitutional difference? Or did the APA nullify

202. See William N. Eskridge, Jr., All About Words: Early Understandings of the "Judicial Power" in Statutory Interpretation, 1776-1806, 101 CoLUM. L. REv. 990 (2001); John Manning, Textualism and the Equity of the Statute, 101 Colum. L. REv. 1 (2001).

203. 5 U.S. (1 Cranch) 137, 177 (1803); see generally Thomas W. Merrill, Marbury v. Madison as the First Great Administrative Law Decision, 37 J. Marshall L. Rev. 481 (2004).

204. Marbury, 5 U.S. (1 Cranch) 137 (holding that although Secretary of State acted lawlessly, the Court lacked jurisdiction to issue mandamus against him); Mark Graber, Establishing Judicial Review? Schooner Peggy and the Early Marshall Court, 51 PoL. Res. Q. 221, 233-36 (1998).

205. Cass R. Sunstein, Beyond Marbury: The Executive's Power To Say What the Law Is, 115 YaLE L.J. 2580, 2589, 2594-95, 2610 (2006) (relying on Report of the Attorney General's Committee on Administrative Procedure, S. Rep. No. 77-8, at 90-91 (1941)).

206. Cass R. Sunstein, Law and Administration After Chevron, 90 Colum. L. Rev. 2071, 2081 (1990); see also Cass R. Sunstein, Constitutionalism After the New Deal, 101 HaRv. L. Rev. 421, 468 (1987) (arguing that post-New Deal evidence strengthens the conclusion that "Congress favors a relatively aggressive judicial role" in reviewing agency actions for consistency with law).

207. See John Duffy, Administrative Common Law in Judicial Review, 77 Tex. L. Rev. 113, 193-99 (1998) (providing the most comprehensive demonstration that a broad understanding of Chevron is inconsistent with the original expectations of, as well as the plain meaning and structure of, the APA).

208. 5 U.S.C. $\$ 706(2000)$.

209. Id. $\$ 706(2)$ (A) (emphasis added).

210. Id. $\S 706(2)(C)$; see generally Duffy, supra note 207, at 193-94; Farina, supra note 200, at $472-74$. 
any New Deal revolution? No, and no. Soon after the APA's adoption, Louis Jaffe explained how the modern administrative state fit into the traditional framework, while at the same time altering it subtly. ${ }^{211}$ Consistent with Marbury and APA section 706, the Supreme Court remains the expositor of what the law is, but when interpreting vague or ambiguous regulatory statutes, the Court ought to be open to agency inputs. Sometimes the statute will be relatively clear to judges, but at other times statutory vagueness will suggest a range of possible meanings, and the Court should be open to the agency's expert interpretation if it were within that range. ${ }^{212}$ This sounds like Skidmore, a decision of the New Deal Court. But Jaffe also believed that the New Deal had regularized a different kind of agency role. In many statutes, Congress has not only enacted binding law, but has, consistent with the APA, delegated to agencies the authority to create binding "law," usually through formal adjudications and legislative rules. Under those circumstances, Jaffe suggested that the role of the Court ought to be more like the deferential judicial review that the Court has applied to social and economic legislation. ${ }^{213}$ Likewise, when reviewing agency lawmaking, the Court should give the agency's rule the benefit of the doubt and overturn it only if it is unreasonable, in light of the statutory text and purposes. ${ }^{214}$ This sounds a lot like Chevron (or Batterton v. Francis, ${ }^{215}$ decided seven years before Chevron).

Jaffe did not work out the details of the foregoing insights, but they suggest the constitutional basis for the Chevron-Skidmore dichotomy that more recent scholars have advocated. ${ }^{216}$ Consistent with Article III and with Marbury, the Court has the authority but not the duty to consider agency inputs when it decides what the law means, especially when the statute is open-textured or Congress did not anticipate the precise legal issue (Skidmore). Consistent with Article I and not inconsistent with Article III and Marbury, Congress has broad power to delegate lawmaking authority to agencies. ${ }^{217}$ In those cases, the role of the courts is more limited (Chevron and Batterton). ${ }^{218}$ "Where an agency acts pursuant to delegated legislative authority, the task of interpretation is merely to define the boundaries" of what Peter Strauss calls the "zone of indeterminacy" within which Congress has authorized the agency to act. ${ }^{219}$

This is hardly an unimportant role for courts, as illustrated by the Oregon

211. Louis L. Jaffe, Judicial Review: Question of Law, 69 HARv. L. Rev. 239, 249-57 (1955).

212. Id.

213. Id.

214. Id. at $263-64$.

215. 432 U.S. 416 (1977).

216. See, e.g., Administrative Conference of the United States, supra note 22; Monaghan, supra note 22, at 26.

217. See Merrill, supra note 22, 2171-75.

218. Batterton, 432 U.S. at 425; Chevron U.S.A., Inc. v. Natural Res. Def. Council, 467 U.S. 837, 844 (1984).

219. Michael Herz, Deference Running Riot: Separating Interpretation and Lawmaking Under Chevron, 6 Admin. L.J. AM. U. 187, 199 (1992) (first quotation in text); Peter Strauss, One Hundred 
Aid-in-Dying Case. If Congress has Article I power to delegate lawmaking authority to agencies and has not curtailed judicial review, judges ought to police agency "law" to make sure that it does not exceed the lawmaking authority Congress conferred upon the agency. In Oregon, Justice Kennedy was right to reject the Attorney General's ambitious effort to attach his authorityexpanding Directive to an earlier procedural rule and was also right to carefully scrutinize the Attorney General's claim that Congress had delegated him lawmaking discretion to regulate state medical practices generally. Even if the Oregon Court had decided that the Attorney General was acting within the congressional delegation, the judicial role would not have ended. The Court would then have had to determine that the Ashcroft Directive does not contradict statutory rules Congress has clearly established and is "reasonable" in light of congressional purposes (the catch-all but easy-to-pass criterion for judicial review of legislation generally).

Thus understood, Chevron is evolution, not revolution, and Skidmore of course survives. Justice Scalia and some of his academic allies seem to believe that statutory ambiguity alone can represent an affirmative congressional delegation triggering Chevron deference. ${ }^{220}$ Such a belief would indeed be revolutionary, but in the sense that an old regime is too quickly tossed aside and, with it, some of our nation's most valuable constitutional traditions. Article I's Vesting Clause grants "all legislative Powers" to Congress. ${ }^{221}$ The Bicameralism and Presentment Clauses of Article I create a process by which the "legislative Power[]" is only exercised when there is a relative political consensus, with inputs from the House, whose members represent small districts and are up for re-election every two years; the Senate, whose members represent entire states and are up for re-election every six years; and the nationally elected and term-limited President. ${ }^{222}$ The point of Article I's structure is that "legislative" rules, those altering basic allocations of rights and duties and supplanting state law, should be difficult to accomplish. ${ }^{223}$ Such a constitutional policy allows Congress to delegate lawmaking authority to other institutions; to maintain, as

Fifty Cases per Year: Some Implications of the Supreme Court's Limited Resources for Judicial Review of Agency Action, 87 CoLUM. L. Rev. 1093, 1124 (1987) (second quotation).

220. See Antonin Scalia, Judicial Deference to Administrative Interpretations of Law, 1989 DuKE L.J. 511, 516; Douglas W. Kmiec, Judicial Deference to Executive Agencies and the Decline of the Nondelegation Doctrine, 2 Admin. L.J. Am. U. 269, 277 (1988); see also LouIs JAFFE, Judicial ConTrol of AdMINISTRATIVE Action 564-65 (1965) (originating this view, then concededly personal to the author). Chevron said that Congress may be said to delegate lawmaking authority to the agency "[i]f Congress has explicitly left a gap for the agency to fill." 467 U.S at 843-44 (emphasis added). This language contains more than its share of mysteries, but the Court has not read the language as broadly as Justice Scalia would. The most natural reading of this language is that if Congress "explicitly" delegates authority to an agency to fill in statutory gaps, that counts as authority to make law.

221. U.S. ConsT. art. I, $\S 1$.

222. U.S. ConsT. art. I, \& 7.

223. INS v. Chadha, 462 U.S. 919, 946-51 (1982); Bradford R. Clark, Separation of Powers as a Safeguard of Federalism, 79 Tex. L. Rev. 1321, 1339, 1430-38 (2001); John Manning, Textualism as a Nondelegation Doctrine, 97 Colum. L. REv. 673 (1997). 
Justice Scalia does, that Congress delegates this power when it leaves ambiguities in statutes would be stretching this constitutional policy well beyond a breaking point. In short, the structure of Article I suggests that congressional delegations of lawmaking authority ought to be explicit, not implicit. Such a clear-statement rule is similar to those adopted by the Court to protect against implicit invasions of executive, judicial, and state power by Congress. ${ }^{224}$

Even if delegations can be implicit, as Mead says (in dictum), they ought not be established by showing that a statute is "ambiguous." 225 To illustrate, Congress enacts ambiguous statutes all the time; the Sherman Act and Section 1983 are two notable examples. Other statutes, like Title VII, are pretty specific but become ambiguous over time, as new issues arise. Judges construe those statutes dynamically, usually with critical input from the Department of Justice and other agencies. But that does not mean Congress has implicitly delegated "legislative" authority to Article III judges; although the lines do blur as circumstances change over time, dynamic statutory interpretation is different from legislative updating. The same holds true for agencies.

As John Duffy has shown, Justice Scalia's broad reading of Chevron is also inconsistent with the structure of the APA. Section 558(b) states: "A sanction may not be imposed or a substantive rule or order issued except within jurisdiction delegated to the agency and as authorized by law."226 The purpose of that provision was "to confine agencies to the jurisdiction and powers so conferred" by Congress. ${ }^{227}$ Given this purpose, it would be anomalous to interpret the APA to allow agencies to claim "implicit" delegations of lawmaking authority. ${ }^{228}$ Indeed, the APA itself contains a clear-statement rule: another statute should not be interpreted to supersede or modify the APA's requirements, "except to the extent that it does so expressly." 229

In short, Articles I and III of the Constitution, as well as the APA, cut against Justice Scalia's ambitious reading of Chevron. These sources of law differentiate between judicial review of agency lawmaking and judicial interpretation in light of agency inputs. They also support the Court's practice in cases like Oregon and Hamdan. This is not the end of constitutional wisdom, however. The Constitution also suggests other norms to guide federal courts when they confront agency interpretations, including those that have been longstanding ones.

First, Article II vests the "executive Power" with the President. ${ }^{230}$ This Executive Vesting Clause carries with it certain inherent powers, chiefly relating

224. See William N. Eskridge, Jr. \& Philip P. Frickey, Quasi-Constitutional Law: Clear Statement Rules as Constitutional Lawmaking, 45 VAND. L. REv. 593, 619-30 (1992).

225. Herz, supra note 219 , at 203-07.

226. 5 U.S.C. $\$ 558($ b) $(2000)$.

227. 92 CoNG. REC. 5654 (1946) (statement of Rep. Walter, House sponsor of APA).

228. See Duffy, supra note 207 , at 198-99.

229. 5 U.S.C. $\$ 559$ (2000) (emphasis added); see Duffy, supra note 207, at 198 n.427.

230. U.S. Const. art. II, $\S 1, \mathrm{cl} .1$. 
to foreign affairs, treaty negotiation, and the armed forces, for which there is textual support in Article II. ${ }^{231}$ The structure of Article II suggests, therefore, that the President ought to get deference when he interprets statutes relating to his command of the armed forces, empowering him to act in foreign crises, and implementing treaties that he has negotiated. But Article II must also be read in connection with Article I, which accords Congress primacy in the regulation of foreign affairs, the governance of the armed forces, and the ratification of treaties. As the famous Steel Seizure Case held, when Congress has set forth rules and procedures relating to matters of national security, armed forces, and the like, the President is obliged to follow those directives. ${ }^{232}$

Concurring in the Steel Seizure Case, Justice Jackson provided a useful framework for interpretive deference, as well as constitutional power. First, he said that, in the arena of foreign affairs and national security (the domain of Curtiss-Wright), Congress's delegations to the President can be implicit. ${ }^{233}$ Second, Justice Jackson defined a "zone of twilight" where the distribution of executive and legislative power is "uncertain" and Congress has not authorized presidential action; in the twilight zone, judges should be deferential to presidential interpretation even where there is no implicit delegation. ${ }^{234}$ Like presidential power, the validity of executive branch application depends on the "imperatives of events and contemporary imponderables rather than on abstract theories of law." ${ }^{235}$ Third, deference even in the foreign affairs context has limits. When the President interprets statutes or his authority contrary to the "expressed or implied will of Congress," he must be rebuffed unless Article II actually "disables" Congress from preempting executive authority. ${ }^{236}$

In Dames \& Moore, the Court explicitly applied the Jackson framework to evaluate President Reagan's executive agreement with Iran that created an arbitral mechanism for resolving hundreds of lawsuits against Iran. ${ }^{237}$ The Court first ruled that the President had the authority to transfer frozen Iranian assets back to Iran and to a fund for paying arbitral awards, pursuant to the International Emergency Economic Protection Act (IEEPA), which authorized the President to "compel" or "prohibit" any "transfer[s]" with respect to transactions or property "in which any foreign country has any interest." ${ }^{238}$ The executive agreement also "suspended" lawsuits against Iran then pending in federal courts. The Supreme Court allowed the suspension even though it was

231. U.S. Const. art. II, $\S 2$, cl. 1 (President as Commander-in-Chief of the armed forces); U.S. Const. art. II, $\S 2$, cl. 2 (presidential authority to negotiate treaties); U.S. ConsT. art. II, $\S 3$ (presidential authority to "receive Ambassadors").

232. Youngstown Sheet \& Tube Co. v. Sawyer, 343 U.S. 579, 585-90 (1950) (Black, J.).

233. Id. at 635-37 (Jackson, J., concurring); id. at 635-36 n.2 (discussing and invoking CurtissWright).

234. Id. at 637.

235. Id.

236. Id. at $637-38$.

237. 453 U.S. 654, 667-69 (1981).

238. Id. at 669-74 (relying on and quoting 50 U.S.C. $\S 1702(a)(1)(B)(2000$ \& Supp. I 2001 ). 
not authorized by IEEPA and even though it was in tension with the jurisdiction conferred on federal courts pursuant to the Foreign Sovereign Immunities Act (FSIA). ${ }^{239}$ The Court maintained that Congress had "acquiesced" in the President's authority to settle American claims against foreign states, but all the examples except one mentioned by the Court were pre-FSIA, and none involved presidential suspension of pending lawsuits. ${ }^{240}$ Because the FSIA Congress had rejected any formal role for the executive in determining federal jurisdiction over lawsuits against foreign states, ${ }^{241}$ it is not clear that the President had a lawful suspension power. ${ }^{242}$ A possible basis for the Court's judgment is that Congress did not address the suspension issue in the text of the FSIA, which might then be liberally and deferentially interpreted to allow suspension of lawsuits, pending resolution of American claims in the arbitral tribunal. ${ }^{243}$ Perhaps Dames \& Moore illustrates Justice Jackson's zone of twilight, where cases may be resolved by reference to the "imperatives of events and contemporary imponderables rather than on abstract theories of law." If so, we consider Dames \& Moore the outer limit of the twilight zone, at the very least.

We do not find persuasive the argument recently made by Jack Goldsmith and John Manning that Article II also includes a "Completion Power," that is, an inherent authority for the President to "complete" projects Congress has started. ${ }^{244}$ They ambitiously maintain that such an inherent power allows Chevron to apply to many areas where there is no congressional delegation. ${ }^{245}$ There is no persuasive support for such a vaguely articulated power in the text or original

239. 28 U.S.C. \& 1602-1611 (2000).

240. Dames \& Moore, 453 U.S. at 679-84.

241. See Beverly Carl, Suing Foreign Governments in American Courts: The United States Foreign Sovereign Immunities Act in Practice, 33 Sw. L.J. 1009 (1979) (examining the law creating special federal jurisdiction for lawsuits against "foreign states" and reporting that Congress rejected a proposal that would have allowed the President to remove cases against foreign states from federal court). One of us was involved in this case, contributing to the Brief for Intervenor-Respondent the Islamic Republic, Dames \& Moore v. Regan, 453 U.S. 654 (1981) (No. 80-2078).

242. That a treaty ratified by the Senate could have accomplished this amendment of the FSIA provides further constitutional argument against Dames \& Moore. The Supremacy Clause in Article VI suggests that "treaties" not only trump state law, but also may amend previous federal statutes. U.S. ConsT. art. VI. Treaties are only those instruments ratified by the Senate, which suggests that executive agreements (not ratified by the Senate) cannot modify previous federal statutes. U.S. CoNST. art. II, § 2 , cl. 2.

243. The Court claimed that the President's suspension order did not divest lower courts of FSIA jurisdiction but merely created a new rule of law binding on the lower courts. Dames \& Moore, 453 U.S. at 684-85. We find that an astounding claim, for it suggests that an executive order (not ratified by the Senate) can modify a federal statute. More persuasive is the Court's further argument, that the international tribunal was a more effective remedy for claimants, especially in light of the fact that IEEPA gave the President authority to transfer all Iranian funds back to Iran, thereby rendering any federal court judgment worthless. Id. at 686-87.

244. Jack Goldsmith \& John F. Manning, The President's Completion Power, 115 Yale L.J. 2280 (2006).

245. Id. at 2298-2301. It is not clear how the Completion Power would work in the Oregon Aid-in-Dying Case. In a debate between Manning and one of the authors at the Yale Law School, Manning declined to defend the Scalia dissent along Completion Power lines. 
meaning of the Constitution, nor in the Court's doctrine; indeed, the authors' best citation for the Completion Power is Chief Justice Vinson's dissenting opinion in the Steel Seizure Case ${ }^{246}$ which the authors say is now the majority view. ${ }^{247}$ That assertion is certainly incorrect as a matter of current Supreme Court doctrine. For a contrary example, recall that the Court in Dames \& Moore explicitly followed the Jackson concurring opinion. The Court in Hamdan explicitly followed the Steel Seizure majority. ${ }^{248}$ More importantly, the Constitution's.text strongly undermines their argument. There is a Completion Power in the Constitution, but it is Article I's Necessary and Proper Clause, which allows Congress, not the President, broadened authority to adopt measures needed to carry out national projects. ${ }^{249}$ The framers apparently considered the "completion" issue and authorized it in Article I-at the same time they were instructing the President to "take Care" that "the Laws" Congress has enacted will "be faithfully executed." 250 The norm the framers had in mind, and that they encoded in the constitutional text, is that of the Steel Seizure majority (and decidedly not the dissenting) Justices: when Congress has legislated, the President's primary duty is to carry out Congress's project, not the one he would have preferred.

Consider a second Constitution-based postulate. The Bill of Rights suggests constitutional support for anti-deference in some cases. If the executive presses a criminal statute too aggressively or bends other statutes in ways that raise free speech (or other constitutional) concerns, the Court should not only withhold deference, but also should be extra-cautious when it construes those statutes. The rule of lenity is the most famous example. It is constitutionally inspired by the notice and equal-treatment norms of the Fifth Amendment and by nondelegation concerns-that Congress, not the courts or prosecutors, should make the moral judgments that certain conduct is criminal. ${ }^{251}$ So the federal government does not get the benefit of statutory ambiguity; in theory, ambiguous criminal statutes are supposed to be interpreted in favor of defendants. Our study shows some continuing influence of the rule of lenity; it played a role in McNally, the Kentucky Kickback Case, among other cases.

In some agency-interpretation cases, the Court has ruled that the "avoidance canon" (interpret ambiguous statutes to avoid "serious constitutional difficul-

246. Youngstown Sheet \& Tube Co. v. Sawyer, 343 U.S. 579, 667 (1952).

247. Goldsmith \& Manning, supra note 244, at 2284-2301 (arguing for post-World War II ratification of Chief Justice Vinson's dissenting opinion in Youngstown).

248. Hamdan v. Rumsfeld, 126 S. Ct. 2749, 2774 n.23 (2006). Even the Solicitor General, defending the President's unauthorized military commissions, did not rely on the Steel Seizure dissent, which Goldsmith and Manning claim is now the prevailing approach. See Brief for Respondent, Hamdan v. Rumsfeld, 126 S. Ct. 2749 (No. 05-184).

249. U.S. ConsT. art. I, \& 8, cl. 18; McCulloch v. Maryland, 17 U.S. (1 Wheat.) 316, 324 (1819).

250. U.S. Const. art. II, $\$ 3$ (emphasis added).

251. See e.g., John Calvin Jeffries, Jr., Legality, Vagueness, and the Construction of Penal Statutes, 71 VA. L. Rev. 189, 198-201 (1985); Dan M. Kahan, Lenity and Federal Common Law Crimes, 1994 Sup. Cr. Rev. 345, 345. 
ties") trumps Chevron. Thus, even when an agency has adopted orders or rules pursuant to congressional delegation, the Court has sometimes ruled against the agency under Chevron Step $1 .{ }^{252}$ The majority opinion in the Oregon Aid-inDying Case considered this concern at Step 0. Under some circumstances, it may be a denial of Fifth Amendment due process for the federal government to prevent a dying person in great pain from obtaining drug therapies that will speed the end of her or his life. ${ }^{253}$ Such sensitive constitutional conclusions might require a clearer statement from Congress, not just the say-so of an aggressive bureaucrat, or even the President himself.

Third, the Constitution's structure is grounded upon the principle of federalism: states have general authority to regulate according to the diverse values and judgments of their own citizens; the federal government can trump state regulation, but only when required or allowed by the Constitution. ${ }^{254}$ The Court has derived from this structure a number of canons requiring super-strong clear statements from Congress before it will allow federal rules to supplant state law or interfere with the operation of state government. ${ }^{255}$ Like the avoidance canon, these constitutionally inspired clear-statement requirements might trump deference to agencies.

Every Term, the Supreme Court must decide several cases asking whether federal statutory schemes preempt state regulations, either explicitly (through preemption provisions in the federal statutes) or implicitly (state regulations interfere with federal statutory operation or goals). Like the Oregon Aid-inDying Case, most of these preemption cases involve federal agency interpretations opposing, supporting, or imposing preemption. The Court has derived from the structure of the Constitution a presumption against congressional interference with the operation of state property, tort, contract, and other police power regulatory law. Thus, "unless Congress conveys its purpose clearly, it will not be deemed to have significantly changed the federal-state balance" by depriving states of their traditional police powers. ${ }^{256}$ Within the Chevron regime, this presumption suggests that the Court ought to be reluctant to conclude

252. See, e.g., Solid Waste Agency v. Army Corps of Eng'rs, 531 U.S. 159, 172 (2001), followed in Rapanos v. United States, 126 S. Ct. 2208 (2006); Edward J. DeBartolo Corp. v. Fla. Gulf Coast Bldg. \& Trades Council, 485 U.S. 568 (1988), followed in BE\&K Constr. Co. v. NLRB, 536 U.S. 516 (2002).

253. See Washington v. Glucksberg, 521 U.S. 702 (1997), analyzed supra note 190 (rejecting, in five concurring opinions, a general constitutional "right to die," but also concluding that it was premature to reject such claims under all circumstances); Cruzan v. Director, Mo. Dep't of Health, 497 U.S. 261 (1990) (saying in dictum that the Due Process Clause protects people's right to refuse unwanted life-saving medical services).

254. On the values of federalism, see Gregory v. Ashcrofi, 501 U.S. 452, 457-65 (1991); Clark, supra note 223, at 1339.

255. For an early survey and analysis of these rules, see Eskridge \& Frickey, supra note 224, at 619-29; William N. Eskridge, Jr. \& Philip P. Frickey, The Supreme Court, 1993 Term-Foreword: Law as Equilibrium, 108 HARV. L. Rev. 26, 102-04 (1994) (containing a list of such rules).

256. United States v. Bass, 404 U.S. 336, 349 (1971); see also Rush Prudential HMO, Inc. v. Moran, 536 U.S. 355, 375-77 (2002) (applying this reasoning to state tort law); BFP v. Resolution Trust Corp., 511 U.S. 531, 542-43 (1994) (state property law). 
that Congress has implicitly delegated to an unelected official the power to preempt state law, precisely as the Court ruled in Oregon, and ought to interpret explicit delegations strictly. ${ }^{257}$ Within the Skidmore regime, where more of the cases fall, agency views will be most persuasive when they provide the Court with factual information on the effects of state regulation on the operation of federal statutes. As Justice Thomas has opined, the Court has most often found the agency input useful when the agency concluded that state regulation should not be preempted. ${ }^{258}$

\section{B. FUNCTIONAL ANALYSIS: AGENCY DEFERENCE AND THE RULE OF LAW, DEMOCRACY,} AND INSTITUTIONAL COMPETENCE

Analysis of the Constitution and the APA by two generations of scholars lends some support to the analytical structure for deference that the Court majority followed in Mead, Oregon, and Hamdan. This analysis strongly counsels against expanding Chevron and abrogating Skidmore (Justice Scalia's preferred regime), but it also counsels against absorbing Chevron into an all-factors-considered regime (probably Justice Breyer's preferred regime). The foregoing formal analysis does not, however, prevent Justice Breyer from interpreting Chevron in a manner more consistent with his philosophy. In Barnhart v. Walton, Justice Breyer gave Chevron deference to a legislative rule adopted pursuant to a lawmaking delegation (sufficient under Mead), but then went on to justify deference also on the grounds that the agency had greater expertise and had consistently adhered to that interpretation for years before encoding it in a rule. ${ }^{259}$ The latter considerations, of course, are those longassociated with Skidmore rather than Chevron deference.

The legal and constitutional authorities suggest that Barnhart is the most plausible competitor to the more sharply defined Chevron-Skidmore approach the Court seemed to announce in Mead and Oregon. We shall pursue that possibility in the discussion that follows. Our primary goal is to articulate the kinds of functional concerns that ought to be relevant to an institutional choice between Barnhart and Mead-Oregon, with some discussion of Justice Scalia's

257. Gonzales v. Oregon, 546 U.S. 243, 273-75 (2006).

258. Pharm. Research \& Mfrs. v. Walsh, 538 U.S. 644, 675-84 (2003) (Thomas, J., concurring); William N. Eskridge, Jr., Vetogates, Chevron, Preemption, Notre Dame L. Rev. (forthcoming 2008) (supporting Justice Thomas's point empirically through analysis of 130 Supreme Court preemption cases involving agency interpretations or rules, at Table 1) (on file with the author); see generally Nina A. Mendelsohn, Chevron and Preemption, 102 Mich. L. Rev. 737 (2004). Tom Merrill is working on a project which will devise default rules for deferring (or not) to agency preemption of state law. See Thomas W. Merrill, Preemption and Institutional Choice, 102 Nw. U. L. Rev. (forthcoming 2008), available at http:www.law.northwestern.edu/colloquium/constitutionallaw/Merrill.pdf.

259. 535 U.S. 212, 221-22 (2002) (giving Chevron deference to recent Social Security Administration (SSA) legislative rule, but also emphasizing that SSA's interpretation was "longstanding" and reflected the agency's "expertise" and "careful consideration" over a period of time); see also Nat'l Cable \& Telecomm. Ass'n v. Brand X Internet Servs., 545 U.S. 967, 1004 (2005) (Breyer, J., concurring) (applying Chevron so long as the agency was not resolving "unusually basic legal question[s]"). 
universal Chevron approach, which might be justified on functional grounds notwithstanding its legal and constitutional problems. To the extent that we can draw conclusions from the functional considerations, we think they do support a simplified deference continuum that differentiates between Chevron and Skidmore deference.

\section{The Functioning of a National Rule of Law}

As we have argued above, standard applications of constitutional text, structure, and original intent support the Court's current approach, for the most part. The APA cuts the same way. For these reasons alone, the "rule of law" supports something like the status quo and argues against a regime where federal courts abdicate their Marbury duty to say what the law is. Some scholars have made an excellent functional argument for a broad understanding of Chevron based upon the rule-of-law values of transparency, predictability, and stability.

Peter Strauss says that the Chevron regime "enhances the probability of uniform national administration of the laws." ${ }^{260}$ Thus, when an agency develops a regime of rules to implement a statutory scheme, those rules have immediate nationwide application, are likely to be coherent with one another, and are able to address issues with greater clarity and precision than either Congress could accomplish through legislation or the federal courts could accomplish through lengthy case-by-case adjudication. ${ }^{261}$ "The U.S. Code, patched together from layers of legislative enactments that are often poorly integrated, frequently is incomprehensible to anyone not an expert in the area," Tom Merrill has added. ${ }^{262}$ In contrast, "the CFR, periodically revised by agencies under their broad delegated authority with an eye to making the law more accessible and improving voluntary compliance, is something that even non-lawyers can often follow."263

A Straussian rule-of-law argument provides a functional reason to read Chevron both more narrowly and more broadly than the Court did in Mead. The advantage of clear, coherent nationwide rules is particularly applicable when the agency engages in rulemaking, with its product appearing in the Code of Federal Regulations. Agency adjudications (including those to which Mead gives Chevron deference) do not generate these kinds of advantages nearly as often, while interpretive rules and guidances (which usually receive only Skidmore deference or less) typically do. ${ }^{264}$ In short, the best functional argument for something like Chevron is that it channels agency articulation of policymak-

260. Strauss, supra note 219 , at 1121 .

261. Id. at 1121-29.

262. Merrill, supra note 22 , at 2154.

263. Id: accord Mistretta v. United States, 488 U.S. 361, 372 (1989) (observing that Congress cannot accomplish its regulatory objectives without the ability to delegate to agencies the job of drafting the precise rules needed to implement statutory goals).

264. See Peter Strauss, The Rulemaking Continuum, 41 DuKe L.J. 1463, 1478 (1992) (discussing levels of deference given by courts to agency decisions and publication rules); see generally Todd D. 
ing into published rules that are easily available to the public. The same argument would support a revised regime that accorded Chevron two-step deference only to agency regulations published in the Code of Federal Regulations or, less ambitiously, promulgated in a form readily available to the public. Moreover, Justice Scalia's universal Chevron approach gets a boost from Strauss's argument if it is willing to make a small concession: to receive Chevron deference, the interpretation must be publicly promulgated by the agency head.

Either the Chevron-Mead or the universal Chevron (Scalia) regime faces a problem under rule-of-law criteria, however. The law's horizontal predictability that Strauss emphasizes (we are better able to say what the rules are at any given time) may come at some expense to the law's vertical predictability (in 2008 we can predict what the rules will be in 2009). ${ }^{265}$ Chevron says that agencies ought to be able to change their interpretations of laws they are delegated authority to implement. ${ }^{266}$ This is potentially an important virtue of the Chevron approach because it allows the law to evolve in response to changed circumstances. From a rule-of-law perspective, however, it is also a potential cost, because it allows agencies to shift interpretations every time there is a new Administration. ${ }^{267}$ Justice Scalia reads Chevron's dictum to ratify agency volte-faces simply in response to changes in political regimes, ${ }^{268}$ a reading that would sharpen Chevron's conflict with the rule of law.

We found, moreover, that the Court has not followed this dictum aggressively-neither in cases involving legislative rules entitled to Chevron deference nor in cases involving interpretive rules entitled to Skidmore deference. We do not know exactly why the Court has been so reticent, but as a theoretical matter the Court's practice can be supported by rule-of-law values. Longstanding agency rules or interpretations are more likely to have generated private as well as public reliance. Changing those rules or interpretations undermines those specific reliance interests, which is a nontrivial rule-of-law cost of deference. (The cost may be justified of course, but the fact that this is a cost must be considered.)

Indeed, very few of the cases that reached the Supreme Court between the 1983 and 2005 Terms (only 3.8\%) involved the kind of ideologically-driven shift in agency interpretations that we see in the Ashcroft Directive (Oregon) or

Rakoff, The Choice Between Formal and Informal Modes of Administrative Regulation, 52 ADMIN. L. REv. 159 (2000).

265. The distinction between horizontal and vertical predictability is drawn from William $\mathbf{N}$. Eskridge, Jr., Interpreting Legislative Inaction, 87 MrcH. L. REv. 67, 116 (1988).

266. Chevron U.S.A., Inc. v. Natural Res. Def. Council, 467 U.S. 837, 862-64 (1984).

267. The classic case is the NLRB, which jettisons its own adjudicative precedents right and left, literally. See generally Ronald Turner, Ideological Voting on the National Labor Relations Board, 8 U. PA. J. LAB. \& EMP. L. 707 (2006) (documenting ideological voting on the Board as the reason driving the Board's overruling and recycling its own precedents).

268. See, e.g., Nat'l Cable \& Telecomm. Ass'n v. Brand X Internet Servs., 545 U.S. 967, 1015-20 (2005) (Scalia, J., dissenting) (arguing for greater judicial tolerance of agency shifts in interpretation). 
the Military Commissions Executive Order (Hamdan). ${ }^{269}$ Instead, more than 96\% of the cases involved either longstanding agency interpretations; new issues forced upon the agency by evolving case law, unanticipated issues, and new statutes or amendments to old ones; or changes in agency interpretations because of new legal circumstances (such as new legislation or judicial rulings). ${ }^{270}$ In the period we studied, we were more struck by the dramatic examples where the Justices themselves sacrificed rule-of-law values and reliance interests by overturning longstanding agency interpretations that had been ratified by Congress, the lower courts, or both. ${ }^{271}$

The weight one places on reliance interests and other stability-in-the-law considerations is going to be driven by context, and so this countervailing value is hard to evaluate. What can be said is that this concern is another argument for giving deference to notice-and-comment rulemaking. Rules are not only highly public and knowable, but they also cannot be easily changed. To change a rule, the agency must provide notice of proposed rulemaking to the public, consider comments, reconsider its proposed rules in light of the public comments, provide reasons for not following significant suggestions, and, finally, defend its final rule if affected parties seek judicial review. ${ }^{272}$ Although agencies claim, with much justification, that the notice-and-comment process slows them down considerably and makes needed changes too expensive, this process does serve rule-of-law values: it ensures both public knowability and transparency of law, while also providing greater assurance of law's relative stability and ordered change. Contrast this process, the one followed by the agency in Chevron, with the less law-like process followed by the Attorney General in Oregon, where the agency's volte-face came out of the blue, with no recorded input from the public or even the medical experts down the street in HHS.

\section{Comparative Institutional Competence}

Everybody has views about the relative competence of agencies and courts to fill in the details of statutory schemes. Unfortunately, those views are in sharp conflict as to the claims most relevant to the role that courts ought to play in reviewing agency lawmaking and statutory interpretation. So we see confident

269. See supra Table 11 (reporting only 39 cases in our population of 1014 where an agency interpretation was apparently driven by a change in presidential administrations).

270. See supra Tables 10 \& 11 (reporting our breakdown of longstanding, evolving, and recent agency interpretations, with a further breakdown of recent interpretations).

271. See, e.g., Cent. Bank v. First Nat'l.Bank, 511 U.S. 164, 192-99 (1994) (Stevens, J., dissenting) (arguing that the majority overturns longstanding SEC interpretation of Securities Exchange Act $\S 10(b)$ that had been adopted by all the courts of appeals and approved by the relevant congressional committees).

272. 5 U.S.C. $\$ 553$ (2000) (informal rulemaking); id. $§ 7 \theta 6(2)$ (a) ("arbitrary and capricious" standard of judicial review); Motor Vehicle Mfrs. Ass'n v. State Farm Mut. Auto. Ins. Co., 463 U.S. 29, $42-43$ (1983) (describing the requirements of $\S 706$ review to include rational explanation normatively connected with congressional purposes and factually grounded in the record before the agency; failure to consider "an important aspect of the problem" can be arbitrary under $\S 706$ ). 
assertions that agencies cannot be trusted because they are "captured" by the interests they are supposed to be regulating ${ }^{273}$ set against equally confident counter-assertions that it is the judiciary that is more easily captured by special interests. ${ }^{274}$ Some serious scholars admire judges as intelligent generalists whose case-by-case approach is an intelligent check on agency misfires, ${ }^{275}$ while other equally serious scholars seem to consider judges little more than bothersome functionaries who need to be kept on a short leash, ${ }^{276}$ and yet other serious scholars suggest that federal judges are ideologues whose voting patterns are more easily explained by their political biases than by their adherence to statutes and precedent. ${ }^{277}$ Finally, eminent legal scholars maintain that even uncaptured agencies would benefit from the knowledge that their decisions will be monitored by reviewing judges, ${ }^{278}$ while other equally eminent scholars claim that judicial second-guessing will throw agencies off course. ${ }^{279}$

Unfortunately, no one has systematic data supporting her or his views, which often amount to ill-informed impressions or even ideologically driven dogma. We are most favorably impressed with the argument that, whatever the relative competence of judges and agencies, second-guessing of agency results and new procedural requirements imposed by courts produce unpredictable results and often undermine the agency's ability to carry out the statutory scheme. ${ }^{280}$ Although institutional competence considerations loom as a less important critical tool for us than it may be for other scholars, we credit the point that two heads are often not as good as one when it comes to public administration.

Additionally, there are some modest propositions as to which there is at least case-study support as well as substantial consensus in the literature. For ex-

273. See, e.g., Michael E. Levine \& Jennifer L. Forrence, Regulatory Capture, Public Interest, and the Public Agenda, 6 J.L. Econ. \& ORg. (Special Issue) 167 (1990); Thomas W. Merrill, Capture Theory and the Courts: 1967-1983, 72 CHI.-KENT L. Rev. 1039, 1064-67 (1997); Richard B. Stewart, The Reformation of American Administrative Law, 88 HARv. L. REv. 1669, 1685 (1975).

274. See, e.g., Spence \& Cross, supra note 199, at 141-42.

275. See, e.g., Owen Fiss, The Supreme Court, 1978 Term-Foreword: The Forms of Justice, 93 HARV. L. Rev. 1 (1979); Stewart, supra note 273, at 1786.

276. See, e.g., Antonin Scalia, A Matter of Interpretation: Federal Courts and the Law 13 (1997) (denouncing the old common law method as obsolescent in the modern regulatory state); VeRMEULE, supra note 199, at 229.

277. See, e.g., James J. Brudney et al., Judicial Hostility Toward Labor Unions? Applying the Social Background Model to a Celebrated Concern, 60 Оноо ST. L.J. 1675, 1689-91 (1999); Revesz, supra note 38, at 1719. This literature, in turn, is contested. See, e.g., William S. Jordan, III, Judges, Ideology, and Policy in the Administrative State: Lessons from a Decade of Hard Look Remands of EPA Rules, 53 AdMin. L. Rev. 45, 98-99 (2001).

278. See, e.g., Mark Seidenfeld, Cognitive Loafing, Social Conformity, and Judicial Review of Agency Rulemaking, 87 CORNELL L. REv. 486, 520 (2002).

279. See, e.g., Jerry L. Mashaw, Prodelegation, 1 J.L. Econ. \& ORG. 85 (1985); R. Shep Melnick, Administrative Law and Bureaucratic Rationality, 44 ADMIN. L. REv. 245, 257 (1992).

280. See Jerry L. Mashaw \& David L. Harfst, The Struggle for Auto SafeTy 242 (1990); Thomas O. McGarity, Some Thoughts on "Deossifying" the Rulemaking Process, 41 DuKE L.J. 1385, 1400-02 (1992); Richard J. Pierce, Jr., The Unintended Effects of Judicial Review of Agency Rules: How Federal Courts Have Contributed to the Electricity Crisis of the 1990s, 43 ADMIN. L. Rev. 7, 8 (1991). This body of literature is grounded upon excellent case studies from several different fields. 
ample, no one seriously disputes the New Deal-era adage that agencies are usually better informed than courts along several dimensions: they understand the subject matter of their statutory scheme and the regulated industry with greater depth, have better access to experts (such as scientists and economists) who provide specialized information in response to targeted inquiries, and have the kind of practical wisdom that comes from dealing with legal issues arising day-to-day under the statute (or perhaps triggered by the agency's own proposals and experiments). To this we should add a further epistemic advantage that we learned from our study, especially from reading hundreds of briefs filed by the Solicitor General between 1983 and 2006: the agency usually knows the legal history of the statute better than any other institution. ${ }^{281}$ Agency officials frequently help draft the statute and are consulted during congressional hearings, propose or resist subsequent amendments to the statute, and are involved in or follow much litigation surrounding the statute. This is useful information for citizens as well as judges trying to figure out "where the law is going" in a particular area.

The agency's superior knowledge of the social, economic, and legal history and context of the statute is a potentially powerful institutional advantage. Whether the agency's epistemic superiority supports deference to its interpretations is contingent of course. It depends not only on the perception of agency bias or neutrality, but also on the reviewing court's confidence in its own knowledge. Thus, the Ashcroft Directive came to the Court burdened by institutional red flags: the Directive and the supporting memorandum from the Office of Legal Counsel revealed a superficial and slanted view of the extensive medical literature on aid-in-dying and seemed driven by a partisan perspective. ${ }^{282}$ There was little to learn from the Directive and the memorandum, and the Court gave them little weight on the Skidmore scale.

Consistent with the foregoing reasoning, our study found little evidence of deference by the Supreme Court as to matters of federal jurisdiction and procedure, where the Justices are just as much experts as (and probably more so than) the executive and independent agencies. The Justices also know, or think they know, a lot about statutory issues involving civil rights, federalism, and substantive criminal law-areas where we found a mixed record of deference. On the other hand, the Justices recognize that they know very little about the intricacies of environmental science, energy regulation, intellectual property,

281. See, e.g., Brief for Federal Petitioners, at 37-43, K Mart Corp. v. Cartier, Inc., 486 U.S. 281 (1988) (No. 86-495) (setting forth the statutory and regulatory history of the import restrictions on goods bearing a trademark owned by an American firm in an excellent Solicitor General brief drafted by now-Dean Robert Rasmussen).

282. See Memorandum from Sheldon Bradshaw, Deputy Assistant Attorney Gen., to the Attorney Gen. (June 27, 2001), reprinted as App. E to Petition for Certiorari at 106a-148a, Gonzales v. Oregon, 546 U.S. 243 (2006) (No. 04-0623) (surveying authorities distinguishing between legitimate medical use of drugs and illegitimate use to "assist suicides," but without any mention of modern authorities in medical ethics explaining the moral bases of the "death with dignity" movement and supporting participation of doctors). 
pension regulation, and bankruptcy. As to these areas, we found the Justices drawing heavily from materials the agencies gave them. Indeed, opinions for the Court were often little more than reprints of the government briefs, even in closely watched cases such as Geier, which involved federal preemption of state tort liability for auto accidents. ${ }^{283}$

Although not addressed by the academic literature, we found examples where the Court concluded (rightly as far as we can tell) that agencies have tremendous advantages in dealing with regulatory uncertainty. ${ }^{284}$ The hardest issues of statutory interpretation tend to be those Congress avoided or did not anticipate when it enacted the statute. Applying the statute to new circumstances involves several different kinds of uncertainty, including uncertainty as to legislative expectations, uncertainty as to the social costs and benefits of different rules or policy balances, uncertainty about the enforceability and feasibility of different rules, and so forth. ${ }^{285}$

Typically, agencies are much better equipped to handle issues of uncertainty than courts are. This is true not only because agencies have superior information and experience with the statute, but also because they have the regulatory flexibility that courts generally lack. ${ }^{286}$ Agencies can conduct or commission pilot studies before adopting a nationwide rule, can solicit public comments directed at areas of uncertainty during notice-and-comment periods, and can modify or revoke rules that do not work. Agencies making law primarily through adjudication experiment in the ways that courts do, through trial and error, but can approach case-by-case adjudication more systematically than generalist courts are accustomed to doing. Not least important, agencies can modify or even overrule their prior positions more easily than courts can. (Hence, there is some tension between the rule-of-law and institutionalcompetence criteria.)

An important limitation of agencies is the flip side of their specialized knowledge and expertise. That is, agencies tend toward tunnel vision, where they pursue their statutory mission with varying degrees of diligence, but often without sufficient regard to a larger normative framework such as the Constitu-

283. Compare Brief for the United States as Amicus Curiae Supporting Affirmance, Geier v. Honda Motor Co., 529 U.S. 861 (2000) (No. 98-1811) (arguing that the Safety Act does not expressly preempt state tort liability for auto manufacturers' failure to provide airbags, but such liability falls because it conflicts with the agency's standard for the issue), with Geier, 529 U.S. at 867-77 (following the Solicitor General's reasoning closely).

284. In addition to Chevron and Geier, which are very much cases about regulatory uncertainty, see also Forney v. Apfel, 524 U.S. 266, 273 (1998) (deferring to HHS on floodgates problem); Walters v. Metro. Educ. Enters., Inc., 519 U.S. 202, 207 (1997) (deferring to EEOC on policy consequences).

285. There is a growing literature on the government's management of uncertainty more generally. See, e.g., Stephen Breyer, Breaking the Vicious Cycle: Toward Effective Risk Regulation 29 (1993) (criticizing the government for spending too much money on reducing or eliminating low-risk harms, while under-spending on reducing higher-risk harms).

286. See generally M. Elizabeth Magill, Agency Choice of Policymaking Form, 71 U. CHI. L. REv. 1383 (2004). 
tion. ${ }^{287}$ Examples of this phenomenon are more common at the Supreme Court level than elsewhere; cases like Oregon, Hamdan, Alvarez-Machain, and McNally are rare at the district or even circuit court level, but occupy a significant chunk of the Supreme Court's docket. Although individual Supreme Court decisions can be criticized for their assertedly incomplete understanding of our constitutional traditions and the useful role they might play in governance, it is much harder to argue that agencies do as thoughtful a job. Compare the shoddy normative effort reflected in the Ashcroft Directive with the much more thoughtful discussion in either the majority or dissenting opinion in Gonzales v. Oregon.

\section{Legitimacy}

Justice Stevens's opinion in Chevron posited that statutory gapfilling or policy elaboration by agencies is more legitimate than similar gapfilling or elaboration by federal judges because agencies are accountable to the President, our only nationally elected official. ${ }^{288}$ Some judges and professors have invoked presidential accountability as a justification for strong deference. ${ }^{289} \mathrm{~A}$ few have even suggested that the President is a more democratically accountable branch of government than Congress, not just the Court. ${ }^{290}$ To be sure, other commentators object that presidential involvement in agency lawmaking and statutory gapfilling cuts against the rule-of-law and institutional-competence justifications for deference. ${ }^{291}$ But the presidential-accountability justification can be best understood as a legitimacy point.

Emphasis on this justification would render the Chevron approach both overand under-inclusive. It would be over-inclusive because relatively few interpretational issues presented to the courts by agency adjudication and notice-andcomment rulemaking reflect regime changes that purportedly come with presidential elections. ${ }^{292}$ Our study of the Supreme Court's docket from 1983-

287. See, e.g., Merrill, supra note 258.

288. Chevron U.S.A., Inc. v. Natural Res. Def. Council, 467 U.S. 837, 865-66 (1984); cf. Motor Vehicle Mfrs. Ass'n v. State Farm Mut. Auto. Ins. Co., 463 U.S. 29, 59 (1983) (Rehnquist, J., concurring in part and dissenting in part) (making a similar point).

289. See, e.g., Mathew D. Adler, Judicial Restraint in the Administrative State: Beyond the Countermajoritarian Difficulty, 145 U. PA. L. Rev. 759, 875-76 (1997); Kenneth W. Starr, Judicial Review in the Post-Chevron Era, 3 Yale J. on Reg. 283, 312 (1986).

290. See, e.g., Jerry L. Mashaw, Greed, Chaos, and Governance: Using Public Choice To Improve THE LAW 152 (1997); Elena Kagan, Presidential Administration, 114 HARV. L. Rev. 2245, 2335 (2001); Lawrence Lessig \& Cass R. Sunstein, The President and the Administration, 94 Colum. L. Rev. 1, 105-06 (1994).

291. See, e.g., Cynthia R. Farina, Undoing the New Deal Through the New Presidentialism, 22 HARV. J.L. \& PUB. POL'y 227 (1998) (arguing that presidential control is anti-regulatory); Thomas O. McGarity, Presidential Control of Regulatory Agency Decisionmaking, 36 AM. U. L. REv. 443 (1987) (arguing that presidential control interferes with agency independence); Peter L. Strauss, Presidential Rulemaking, 72 CHI.-KENT L. REV. 965 (1997) (arguing that presidential rulemaking threatens to upset the constitutional checks and balances within the national government).

292. Elena Kagan argues that Chevron deference should be limited to issues for which there has been significant White House input. Kagan, supra note 290, at 2333-35. But see David Barron \& Elena 
2006 found very few cases like Chevron, where a new President and his appointees shifted statutory policy to reflect an ideological change endorsed in the prior election. And when those cases came to the Supreme Court, the Justices often overturned them, as they did in Hamdan, the Military Commissions Case. Additionally, most White House involvement in legislative rulemaking is hard to detect, usually for political reasons. ${ }^{293}$ The presidential accountability justification for Chevron is also under-inclusive because there is often significant White House influence on interpretive rules and agency practices that receive only Skidmore deference. This could support Justice Scalia's view that Chevron should govern any interpretation adopted by the head of an agency-namely, the person or group appointed by the President and, in the case of executive agencies, removable by the President as well.

A serious normative problem with strong versions of the presidentialaccountability justification is that they rest upon no systematic examination of presidential accountability and the extent to which his accountability actually drives agency lawmaking (Chevron) or interpretation (Skidmore). Scholars who tout the President as nationally accountable in contrast to a parochial Congress are on particularly weak ground. As Cynthia Farina and Jide Nzelibe argue, the President, chosen by an Electoral College that frequently graduates preference outliers, does not necessarily reflect majoritarian preferences better than Congress does. ${ }^{294}$ Unlike members of Congress, the President can only be reelected once, a fact that diminishes his theoretical accountability advantage.

A weaker version of the argument is the one Justice Stevens originally penned, that agencies have accountability advantages over judges. ${ }^{295}$ Our study contributes this point to the argument: agencies are more democratically accountable, not so much because of their link to the White House, but because of their links to Congress. Our reading of government briefs in Supreme Court cases suggests to us that agencies usually have institutionally superior access to the original expectations of the legislators. Add this further point: agencies also have better knowledge than courts about current congressional expectations,

Kagan, Chevron's Nondelegation Doctrine, 2001 SuP. CT. REv. 201, 234-37 (retracting that limitation and arguing for the application of Chevron to any interpretation adopted by an agency head appointed by the President; a much broader application for Chevron); see also Stack, supra note 165 (arguing more cautiously that when Congress has delegated lawmaking authority to the President, his interpretations are entitled to Chevron deference).

293. Lisa Schultz Bressman, Beyond Accountability: Arbitrariness and Legitimacy in the Administrative State, 78 N.Y.U. L. REv. 461, 506-11 (2003). For example, the so-called "Republican war on science" that has been fought out of the White House during the George W. Bush Administration has been conducted through backdoor (therefore hard to detect) influences on more formal decisionmaking processes. See John Horgan, Political Science, N.Y. ThMes Book Rev., Dec. 18, 2005, at 11 (reviewing Chris Mooney, The Republican War on Science (2005), and discussing the Bush Administration's repeated attempts to overrule expert opinion in scientific and environmental agencies).

294. Cynthia R. Farina, Faith, Hope, and Rationality or Public Choice and the Perils of Occam's Razor, 28 Fla. St. U. L. Rev. 109, 128-29 (2000); Jide Nzelibe, The Fable of the Nationalist President and the Parochial Congress, 53 UCLA L. REv. 1217, 1231-42 (2006).

295. Chevron U.S.A., Inc. v. Natural Res. Def. Council, 467 U.S. 837, 865-66 (1984). 
through formal congressional oversight and budgetary hearings and through the myriad informal processes of Congress-agency communication. ${ }^{296}$

Our empirical study reveals the power of this last point. When the statutory materials are less than determinate and the issue is one of major public attention, the Court is usually at risk, because a badly justified decision that riles a portion of the body politick may undermine the Court's legitimacy. Indeed, that is what happened during the $1988 \mathrm{Term}$, when the Court handed down conservative readings of our major job discrimination statutes in six high-profile cases. ${ }^{297}$ Even Republican politicians denounced the Court for "reneging" on Congress's commitment to the anti-discrimination norm in the workplace, and in 1991 Congress and the White House delivered a sweeping statutory rebuke for the Court's work product that Term. ${ }^{298}$ In half of the controversial cases, George H. W. Bush Administration Solicitor General Charles Fried had submitted amicus briefs arguing for more liberal interpretations of civil rights statutes. ${ }^{299}$ If the Court had gone along with the Administration, and the careful legal reasoning its briefs supplied, the "reneging" charges would surely have been less fierce. We hypothesize that the Court is much (by a wide margin) more likely to be overridden by Congress when it rejects agency statutory interpretations than when it accepts those interpretations. ${ }^{300}$

There is another problem with the presidential-accountability argument for Chevron: Is legitimacy in our constitutional system the product of nothing but majoritarian preferences? If the President's advisers took a poll which reliably found $5.1 \%$ of Americans opposed to "death with dignity" or "assisted suicide" (assume the terminology did not make a difference), would the Ashcroft Directive have been more legitimate? Not much. Are the military commissions rendered legitimate by popular support, even if they violate the nation's treaty commitments and statutory commands? Clearly not.

The framers of the U.S. Constitution considered and rejected lawmaking by direct vote of We the People, in part because they were suspicious of majority

296. See William N. Eskridge, Jr. \& John Ferejohn, The Article I, Section 7 Game, 80 GEo. L.J. 523, 539 (1992); see also Einer Elhauge, Preference-Estimating Statutory Default Rules, 102 CoLuM. L. REv. 2027, 2126-28 (2002).

297. Indep. Fed'n of Flight Attendants v. Zipes, 491 U.S. 754 (1989) (narrow interpretation of Title VII's counsel fees provision); Patterson v. McLean Credit Union, 491 U.S. 164 (1989) (narrow interpretation of $\S 1981$, disallowing a claim of race-based job termination); Lorance v. AT\&T Tech., 490 U.S. 900 (1989) (broad, employer-protective interpretation of Title VII's statute of limitations); Martin v. Wilks, 490 U.S. 755 (1989) (interpreting the law of judgments to allow "reverse discrimination" plaintiffs to challenge affirmative action decrees); Wards Cove Packing Co. v. Atonio, 490 U.S. 642 (1989) (narrow interpretation of Title VII's disparate impact claim for relief); Price Waterhouse v. Hopkins, 490 U.S. 228 (1989) (narrow interpretation of Title VII in "mixed motive" cases).

298. Civil Rights Act of 1991, Pub. L. No. 102-166, 105 Stat. 1071 (overriding all six decisions cited in note 297 supra); see William N. Eskridge, Jr., Reneging on History? Playing the Court/Congress/ President Civil Rights Game, 79 CAL. L. Rev. 613 (1991) (describing the furor created by the Court's aggressive cutback on civil rights statutes and anticipating the 1991 override).

299. The Solicitor General filed amicus briefs firmly supporting civil rights claims in Patterson and Lorance, and supporting a fairly pro-plaintiff interpretation of plaintiff's burden in Hopkins.

300. This empirical claim will be tested in subsequent work. 
rule and in part because they believed that governmental legitimacy came from public deliberation in pursuit of the "public interest," and not based on simple responsiveness to the "will of the people." ${ }^{301}$ Unfortunately, the framers failed to anticipate several phenomena, including the democratization of American politics and public values ${ }^{302}$ and the modern administrative state where much lawmaking is accomplished by agencies. ${ }^{303}$ These new phenomena have inspired some judges and scholars to justify an expansive understanding of Chevron based mainly on agencies' greater responsiveness to popular opinion. They believe democratization and bureaucratization can be compatible, especially under the umbrella of the nationally elected President. We have argued above that this kind of synthesis has a poor link to majority values. We now add that the presidentialist synthesis too readily abandons the legitimacy-conferring features of deliberation. The disastrous Ashcroft Directive is exhibit $A$ for both of these defects: it not only reflected the views of an electoral minority, but it also sought to shut down national deliberation about aiding-in-dying, as the media and citizens of other states observed the Oregon policy in action.

Philosopher Henry Richardson advances a different kind of synthesis. Like the presidentialists, he embraces both democracy and bureaucracy-but his synthesis rests upon, rather than resists, the legitimacy-conferring features of open public deliberation. Thus, Richardson argues for "democratic rulemaking," whereby agencies that are both public-regarding (professional) and responsive (political) deliberate about general goals and particular rules only in contexts where citizens can meaningfully contribute and provide feedback. ${ }^{304}$ This best approximates notice-and-comment rulemaking, but is reformed so that fewer perspectives are left out than we see now. ${ }^{305}$ Rulemaking, in Richardson's vision, advances both democracy and the public interest when Congress has

301. The Federalist Nos. 10 \& 51 (James Madison) (rejecting direct democracy and arguing for a representative democracy); see also Cass R. Sunstein, The Partial Constitution (1993); Rebecca L. Brown, Separated Powers and Ordered Liberty, 139 U. PA. L. Rev. 1513, 1515-16 (1991); Frank Michelman, The Republican Civic Tradition, 97 YALE L.J. 1493, 1508-09 (1988).

302. See Alexis de Toceueville, Democracy IN AMerica (Arthur Goldhammer trans., Penguin Putnam 2004) (1837) (observing that democratic values had saturated American public culture by the 1830s); Alexander Kayssar, The Right To Vote: The Contested History of Democracy in the United STATES (1999) (tracing the dramatic expansion of the franchise in the early nineteenth century and, again, after World War I).

303. See Gary Lawson, Delegation and Original Meaning, 88 VA. L. REv. 327, 370 n.168 (2002).

304. RichARDSON, supra note 185, 214-19; see also Mark E. Warren, Deliberative Democracy and Authority, 90 AM. Pol. ScI. Rev. 46, 47 (1996). Complementary accounts have been derived from standard civic republican sources by Bressman, supra note 293; Mark Seidenfeld, A Syncopated Chevron: Emphasizing Reasoned Decisionmaking in Reviewing Agency Interpretations of Statutes, 73 TEX. L. REv. 83 (1994).

305. RichARDSON, supra note 185, at 219-22 (criticizing notice-and-comment rulemaking for not considering enough voices and not considering them early enough). Richardson mentions "negotiated rulemaking" as a possible amelioration but follows the reservations of Jody Freeman. See Jody Freeman, Collaborative Governance in the Administrative State, 45 UCLA L. REv. 88 (1997). Another innovation since Richardson set forth his theory is that some agencies now maintain internet sites for notice-and-comment rulemaking; this potentially opens up rulemaking to more of the public. 
vested the agency with responsibilities through a clear mandate, when legislators and other public officials examine the agency's progress toward clarifying statutory goals and implementing them, and when the agency develops a professionalism that justifies the public trust that has been placed in its hands. ${ }^{306}$

The most legitimate process (rulemaking) may come at a substantial institutional cost, however. A number of scholars argue that judicial preferences for rulemaking, and then judges' tendency to send agencies back for more work, has ossified the administrative process. ${ }^{307}$ Rejecting the ossification hypothesis, other scholars maintain that careful rulemaking creates better rules and that the extra process is worth it in terms of results. ${ }^{308}$ We take no position on this debate, except to note that reasonable minds have reached different conclusions, and that the ossification concern is genuine even if indeterminate.

\section{PUTTING IT ALL TOGETHER: WHAT SHOULD THE COURT'S DEFERENCE REGIME LOOK LIKE?}

Our main positive findings are that the Justices defer a lot to agency interpretations, but their deference is not driven by Chevron and the other formal regimes; statutory subject matter and institutional context appear to be more important in the Justices' own evaluation of agency inputs than the rhetorical "deference" regime the Justices attach to the case. The Justices are particularly open to agency analyses of the consequences and risks posed by different interpretations, especially as they relate to statutory-reliance interests and congressional purposes, when the statute involves national security, tax, or instrumental economic regulation. In contrast, the Justices believe themselves more confident when interpretive issues involve process, anti-discrimination norms, criminal liability and sentencing, and federal-state relations. As a means for deciding the cases before them, the Justices' subject-matter-driven ad hoc approach has not been a disaster and might charitably be considered a practical success.

Even though the deference continuum we have uncovered seems to be working non-disastrously, or even well enough, at the Supreme Court level from an ex post point of view, it is a significant missed opportunity from an ex ante point of view-one that considers the deference continuum as a structure within which lower courts, legislators, and citizens must operate. Our positive suggestions start with some general principles that should guide the Court's deference

306. RICHARDSON, supra note 185 , at 222-30.

307. See Mashaw, supra note 279 ; MASHAw \& HARFst, supra note 280, at 224-54 (providing an excellent case study of agency paralysis because of judicial review and endless rulemaking); Melnick, supra note 279, at 246; Richard J. Pierce, Jr., Seven Ways To Deossify Agency Rulemaking, 47 ADMIN. L. Rev. 59 (1995); Paul R. Verkuil, Comment: Rulemaking Ossification-A Modest Proposal, 47 ADMIN. L. REv. 453 (1995).

308. See, e.g., Kevin MacDonald, Shifting Out of Park: Moving Auto Safety from Recalls to REASON 96-97 (2006); William S. Jordan, III, Ossification Revisited: Does Arbitrary and Capricious Review Significantly Interfere with Agency Ability To Achieve Regulatory Goals Through Informal Rulemaking?, 94 Nw. U. L. REv. 393 (2000) (answering no to the question posed in the title). 
decisions and will then turn to rule-based clarifications to the Court's overall deference jurisprudence. We shall conclude with some process points that might be useful to the Court, whatever deference regime it ends up following (including the current continuum, applied in an ad hoc way).

Our overall goal in making these suggestions is to improve the ability of the judiciary and the country to have an increased benefit of agency inputs in statutory interpretation but without the sacrifice of the rule of law, legislative supremacy, and the judicial role that more extreme proposals might bring. We appreciate that some of our suggestions might be presumptuous, perhaps because it may not be easily possible for nine Justices to come together on a more coherently articulated and consistently applied approach. With respect, we would still suggest to the Chief Justice of the United States and his colleagues that there are few (if any) matters of judicial practice more deserving of their attention than this one.

\section{Precepts That Ought To Guide the Court's Deference Jurisprudence}

The degree of deference the Supreme Court ought to afford an agency interpretation of the statute it is applying should involve three variables. First: Is the agency interpretation consistent with larger public norms, including constitutional values (Oregon)? Agencies are statutory specialists and often operate with a tunnel vision, or sometimes reflect a partisan perspective. The greatest value added by the judiciary flows from the fact that judges are generalists and enjoy life tenure that gives them potential freedom from partisanship. The recent Military Commissions Case and Aid-in-Dying Case illustrate the constructive role the Court can play when it trumps an excessively ambitious agency under the aegis of fundamental national values such as due process, federalism, and privacy.

Second: Is the agency interpretation pursuant to a congressional delegation of lawmaking authority (Chevron/Mead)? For the same kinds of legitimacy and rule-of-law reasons that the Court takes a deferential attitude toward congressional judgments in enacted statutes, the Court should take a deferential attitude toward agency judgments entailed in rules and orders pursuant to delegated lawmaking authority. Following Henry Richardson, this reason for deference is greatest when the agency process looks legislative, as it usually does in rulemaking proceedings, where affected interests provide relevant information that the agency must consider.

Third: Is the agency applying special expertise to a technical issue, seriously applying its understanding of the facts to carry out congressional purposes (Skidmore)? Our empirical examination of the Supreme Court's practice suggests that this is the most significant variable, and in our view it ought to be in most cases. Many of the subject-matter areas before the Court are ones where the Justices have neither practical experience nor the intellectual tools to form mature judgments about the complicated policy issues entailed in the legal questions presented. When the agency is staffed with experts and it is making a 
Table 22. Proposed Structure for the Court's Deference Jurisprudence

\begin{tabular}{|l|c|c|c|c|c|c|c|c|}
\hline $\begin{array}{l}\text { Is the agency } \\
\text { interpretation } \\
\text { consistent with } \\
\text { larger public } \\
\text { norms? }\end{array}$ & $\mathrm{Y}$ & $\mathrm{Y}$ & $\mathrm{N}$ & $\mathrm{N}$ & $\mathrm{Y}$ & $\mathrm{Y}$ & $\mathrm{N}$ & $\mathrm{N}$ \\
\hline $\begin{array}{l}\text { Is the agency } \\
\text { interpretation } \\
\text { pursuant to a } \\
\text { congressional } \\
\text { delegation of } \\
\text { lawmaking } \\
\text { authority? }\end{array}$ & $\mathrm{Y}$ & $\mathrm{Y}$ & $\mathrm{Y}$ & $\mathrm{Y}$ & $\mathrm{N}$ & $\mathrm{N}$ & $\mathrm{N}$ & $\mathrm{N}$ \\
\hline $\begin{array}{l}\text { Is the agency } \\
\text { applying special } \\
\text { expertise to a } \\
\text { technical issue, } \\
\text { carrying out } \\
\text { congressional } \\
\text { purposes? }\end{array}$ & $\mathrm{Y}$ & $\mathrm{N}$ & $\mathrm{N}$ & $\mathrm{Y}$ & $\mathrm{Y}$ & $\mathrm{N}$ & $\mathrm{Y}$ & $\mathrm{N}$ \\
\hline $\begin{array}{l}\text { Level of Deference } \\
\text { Chevron }\end{array}$ & Chevron & $\begin{array}{l}\text { Chevron } \\
\text { with } \\
\text { Skepticism }\end{array}$ & $\begin{array}{l}\text { Chevron } \\
\text { with } \\
\text { Skepticism }\end{array}$ & Skidmore & Skidmore & $\begin{array}{l}\text { Skidmore with } \\
\text { Skepticism }\end{array}$ & $\begin{array}{l}\text { Skepticism } \\
\text { and Anti- } \\
\text { deference }\end{array}$ \\
\hline
\end{tabular}

serious effort to carry out congressional purposes, the Court should be most deferential. Some, but less, deference is appropriate in cases where the agency knows more than the Justices but has no particular expertise advantage compared with other amici in a case.

Table 22 provides a roadmap as to how the factors work together. If the Justices answer "yes" to all three questions, they will and ought to be highly deferential to the agency's interpretation; this was the legal context for the Court's deference in Bragdon v. Abbott (the AIDS-as-Disability Case), ${ }^{309}$ and Auciello Iron Works (the Labor Contract Case). ${ }^{310}$ If they answer "yes" to the first question and either of the other two, they will and ought to be deferential to the agency's interpretation; this, in our view, was the situation in Chevron itself. If the Justices answer "no" to the first question but "yes" to the other two, the Justices will and ought to struggle with the task of accommodating their understanding of public norms and the agency's understanding of its mandate; one or both understandings will have to give way, and we believe that the Justices ought to be open to rethinking their own (quasi)constitutional priors, at least as applied to the case at hand. In Geier, federalism concerns gave way to the agency's expert view about national traffic-safety regulation; in contrast, the Justices in Hamdan trumped presidential judgment about national security with due-process norms and apparent congressional purposes. (In both cases, there were strong dissents, as both judgments were contestable ones.) If the Justices answer "no" to all three questions, they will and ought to be skeptical and anti-deferential toward the agency's interpretation; examples of this include Oregon, the Aid-in-Dying Case, and McNally, the Kentucky Kickbacks Case.

309. Bragdon v. Abbott, 524 U.S. 624 (1998).

310. Auciello Iron Works, Inc. v. NLRB, 517 U.S. 781 (1996). 
We have some specific suggestions as to how these three variables might be translated into a workable doctrine by the Justices, but we should not press those suggestions too hard, for we are not sure what would work for the Justices and we are somewhat skeptical they could stick to one doctrinal framework. Several Justices have personally distinctive approaches to deference. Justice Breyer, for example, is very deferential when the agency is applying its comparative expertise or there has been discernible public or private reliance. Justice Scalia is not particularly deferential unless the statutory text is vague or open-ended. Justice Stevens considers constitutional norms and, especially, statutory purpose as his most important variables. How these individual Justices approach the deference issue also depends on how it is briefed by the Solicitor General and his assistants. Not least important, all of the Justices are unconsciously influenced by their views of the substantive issues in the cases (like Gonzales v. Oregon) where they have personal views.

For all these reasons, it is not easy for the Supreme Court to develop a coherent deference jurisprudence. It is possible if one Justice (preferably the Chief Justice) took it upon himself or herself to monitor everyone's opinions to make sure the deference issue was treated, and treated consistently, with a coherent standard, and to object in published opinions when that does not occur. Obviously, this is a matter for the Justices' own time management, and one or more of them would have to make this a matter of some priority. Should they?

On the one hand, the Court's substantially ad hoc approach has been workable in connection with its own caseload. Indeed, we do not think the existence of a particular deference regime-whether it be the continuum we have outlined or Justice Scalia's universal Chevron approach or Justice Breyer's synthesis of Chevron and Skidmore-makes a big difference in how the Justices decide actual cases. Our empirical examination of the Court's 1014 agency-interpretation cases between Chevron and Hamdan makes us skeptical that any doctrinal framework would affect the Court's approach to any but a handful of cases. Thus, in Gonzales v. Oregon, we do not think the Attorney General's directive would have prevailed even if all nine Justices had committed themselves to a universal Chevron approach; the majority Justices could have trumped Chevron with the constitutional-avoidance canon. Nor would the Oregon dissenters have been willing to override the Ashcroft Directive even if they and the other Justices had been committed to the all-factors-considered approach or even a universal Skidmore. Indeed, the dissenters dissented, essentially, because they agreed with the Attorney General: aid-in-dying is "assisted suicide," one half step away from murder.

On the other hand, there are nontrivial institutional reasons the Court ought to invest some institutional capital in developing and consistently applying a more coherent approach to agency deference. The Court's own hodge-podge of deference doctrines serves no useful purpose, and at the very least it ought to be trimmed. More important, if we are anything close to correct in asserting the almost random application of Chevron and the other regimes, the Court ought to 
be mildly embarrassed that its much-trumpeted Chevron Revolution is beginning to look like a Potemkin village. Most important, there are systematic institutional reasons why the Chief Justice of the United States ought to take the lead in tidying up the Court's deference jurisprudence.

The Court's deference continuum is both complicated and is applied in a context-specific way-in other words, it is a classic example of a "standards" rather than a "rules" approach to a legal issue. ${ }^{311}$ Although a standards approach works fine for the Court's own caseload, it is not nearly so good as a rules approach for lower courts, agencies, and litigants who want to know, in advance, when an agency interpretation is entitled to Chevron deference. The Mead mess illustrates this problem. The Court's opinion was filled with vague pronouncements about implicit congressional delegations of lawmaking authority, which has produced not only confusion but chaos among lower court panels, especially in light of somewhat different standards-like pronouncements (finding Chevron-significant the agency's careful consideration and its consistent interpretation over several administrations) that the Court made a year later in Barnhart v. Walton. ${ }^{312}$

Because most of the agency-monitoring that goes on in the federal system is accomplished by the lower courts and within the agencies themselves, a rules approach is probably preferable for determining what deference regime is applicable. ${ }^{313}$ This is because it is more important for agencies, firms, and citizens to know what the precise parameters are than for those parameters to be exactly right in each case. Moreover, an important audience for the Court's deference jurisprudence is Congress itself, which is the trigger under Mead for the application of Chevron. Even if Congress does not follow the Court's jurisprudence closely, the Court has a systematic obligation to provide clearer guidance to legislators as they consider the consequences of different delegation structures. ${ }^{314}$

\section{Simplify and Clarify the Deference Continuum}

In the spirit of the foregoing discussion, we shall now suggest ways that the Court's deference regime can be simplified and clarified, if the Justices are

311. Henry M. Hart, Jr. \& Albert M. Sacks, The Legal Process: Basic Problems in the Making and Application of Law 139-41 (William N. Eskridge, Jr. \& Philip P. Frickey eds., Foundation Press 1994) (1958) (providing the classic account of the choice between rules and standards for legal regulation); $c f$. Caleb Nelson, What Is Textualism?, 91 VA. L. Rev. 347 (2005) (applying the rules-versusstandards literature as a way of understanding the distinction between a textualist like Scalia and an intentionalist like Breyer).

312. 535 U.S. 212, 219-22 (2002); see also Krzalic v. Republic Title Co., 314 F.3d 875 (7th Cir. 2002) (vigorous debate between Judges Posner and Easterbrook over what Mead and Barnhart require of lower courts); Bressman, supra note 32, at 1457-74 (exploring the variety of ways Mead and Barnhart have produced a "muddle" in the lower courts).

313. Cf. Merrill, supra note 198, at 819-26 (urging the Court to adopt bright-line meta-rules for Chevron Step 0 inquiries).

314. See William N. Eskridge, Jr. \& John Ferejohn, Politics, Interpretation, and the Rule of Law, in The Rule of Law 4 (Ian Shapiro ed., 1994). 
willing to devote some effort to this issue. Most of what follows would be pretty easy to announce as a matter of doctrine.

Suggestion One: Boil Down the Deference Continuum to Oregon, Skidmore, and Chevron. Following the constitutional structure described above and the practical considerations revealed in our empirical analysis, our biggest suggestion is Thoreauvian: simplify, simplify, simplify. The deference continuum should be reduced to Oregon, where an agency interpretation raising constitutional concerns, such as those reflected in the Bill of Rights, is treated with skepticism; Skidmore, the independent but informed-by-agency-inputs judgment model suggested by Article III; and Chevron, the deference model when Congress has delegated lawmaking authority to agencies pursuant to Article I.

Consistent with our empirical findings, the default regime-the one the Supreme Court should make generally clear it is applying if the opinion for the Court says nothing - ought to be an expanded understanding of Skidmore. Under Skidmore, the Court ought to consider factual materials as well as legal arguments, such as are found in Solicitor General amicus briefs; informal agency interpretations found in policy guidances, manuals, websites, and the like; and even "litigating positions" taken by the agency and supported by briefing. Hence, we would explicitly expand Skidmore to include instances we coded as "consultative deference" or Skidmore-Lite (reflecting our judgment that in many of the consultative cases a citation to Skidmore would have been appropriate). The Court should make clear-or perhaps just continue to assume what we would make explicit-that it will seriously consider the factual and analytical materials upon which agencies rely when they interpret statutes.

Moreover, we urge the Court to abrogate the special deference regimes we have gathered under the Beth Israel umbrella and accord those cases either Chevron or Skidmore deference, depending on the existence of a congressional delegation. There is no persuasive reason to perpetuate the earlier deference regimes, and, in areas like labor law, the Court's alternation between Beth Israel and Chevron in otherwise similar cases only creates doctrinal confusion. There is even less justification for a separate Seminole Rock.regime. The Court invokes Seminole Rock in a tiny percentage of cases where it is potentially applicable, which creates the impression that it is being invoked either randomly or selectively. The amount of deference Seminole Rock requires has always been ambiguous, also contributing to doctrinal confusion for those lower courts and commentators who follow such matters. ${ }^{315}$ To the extent that Seminole Rock deference exceeds Chevron deference, it is open to abuse by agencies that try to bootstrap unauthorized policy innovations under cover of interpreting vague housekeeping rules.

Somewhat hesitantly, we also urge the Court to abandon Curtiss-Wright as a

315. See Hickman \& Krueger, supra note 32, at 1307-09 (noting that lower courts have already tended to apply Skidmore rather than Seminole Rock when agencies are interpreting their own regulations). 
separate deference category. This is a category the Court has rarely invoked explicitly; only two Justices invoked Curtiss-Wright deference in Hamdan, where it would seem to have been applicable. ${ }^{316}$ "When the President takes measures incompatible with the expressed or implied will of Congress, his power is at its lowest ebb," and that is the rule followed in Hamdan. ${ }^{317}$ Where Congress has not legislated, Curtiss-Wright correctly suggests that the President will sometimes have inherent authority to act in matters of diplomacy, armed forces, war, and treaty making. And Congress can delegate lawmaking or other coercive authority to the President, using the traditional conventions that Kevin Stack has identified. ${ }^{318}$

The doctrinal interment of Curtiss-Wright super-deference would not mean that the President's judgment would never receive special treatment in foreign affairs and national security cases. Congress has generally not been stingy when it has delegated authority to the President in times of war or national emergency, and such delegations are entitled to the powerful deference accorded by Chevron. ${ }^{319}$ Cardozo-Fonseca, the Asylum Case, illustrates this approach. Textual plain meaning and the legislative and treaty background of the statute established that the INS's burden-of-proof rules in asylum cases were incorrect, but the Court left the agency plenty of room to develop rules and standards within the general approach demanded by the statute. More important, even where Congress has not delegated the President lawmaking authority and the President does not have such authority under Article II, Skidmore deference assures the executive branch broad latitude. We think that the Court gave too much latitude in Alvarez-Machain, the Mexican Kidnapping Case, ostensibly decided under a consultative deference standard, but this makes our point. So long as the Justices feel the President is much more competent than they to handle delicate foreign affairs issues, their Skidmore-inspired deference will go a long away toward accommodating presidential initiatives.

Suggestion Two: Clarify Chevron's Domain. Consistent with Mead and a fairly longstanding academic consensus, Chevron's framework ought only be applied to agency interpretations pursuant to congressional delegations for the agency to create legally binding rules, orders, or directives. The Court says, and

316. Hamdan v. Rumsfeld, 126 S. Ct. 2749, 2846 (2006) (Thomas, J., joined by Scalia, J., dissenting). The majority ignored Curtiss-Wright, and Justice Alito (a dissenter on all procedural as well as substantive issues that divided the Court in Hamdan) declined to join the Curtiss-Wright deference discussion in Justice Thomas's dissent. Chief Justice Roberts did not participate in the case, because he had joined the opinion below which was reversed in Hamdan. Notably, the lower court did not invoke Curtiss-Wright deference. See Hamdan v. Rumsfeld, 415 F.3d 33 (D.C. Cir. 2005).

317. Hamdan, 126 S. Ct. at 2800 (Kennedy, J., concurring in part) (quoting Youngstown Steel Sheet \& Tube Co. v. Sawyer, 343 U.S. 579, 637 (1952) (Jackson, J., concurring)).

318. Kevin M. Stack, The President's Statutory Powers To Administer the Laws, 106 ColuM. L. REv. 263 (2006) (arguing that the President should only be able to claim statutory power if the statute expressly grants such power and, if power is granted to an executive officer, there should be a strong negative inference against the President having directive authority).

319. See Stack, supra note 165 , at 539 (arguing that congressional delegations of lawmaking authority to the President should be accorded Chevron deference). 
we emphatically agree, that Chevron deference is exceptional and represents a departure from the traditional multi-factored approach to statutory interpretation by judges. If that is the case, then Chevron should only be triggered when the agency has been lawfully delegated lawmaking authority, and not just general authority to implement and interpret the statute.

The Court should identify statutory authorizations with greater care and then stick to its characterizations. ${ }^{320}$ For example, the Court should probably follow the tax bar and give the IRS Skidmore deference when it issues substantive regulations, letters, or rules pursuant to its section 7805 general rulemaking authority. Chevron deference should be reserved for those cases where the IRS is acting pursuant to a more particular delegation of lawmaking authority. As to the U.S. Code more generally, we have identified almost two dozen statutes that regularly trigger Chevron deference. ${ }^{321}$ The Court ought to confirm or edit this list and then add to it systematically. ${ }^{322}$ And then the Court should stick with the list, systematically invoking or at least mentioning Chevron when agencies are acting pursuant to the lawmaking delegations in those statutes.

The Court should also make clear what its bright-line rule is and then stick to it. This would have the rule-of-law advantage of providing lower courts and agencies themselves with clearer indication of how much freedom different agencies have under various enabling legislation. Thus, the Court should clarify the position it took in Mead but not in the direction it went in Barnhart. ${ }^{323}$ Consistent with the position they have taken in the federalism and separation-ofpowers arenas, the Justices should adopt a clear-statement rule for congressional

320. Specifically, the Court needs to address the Merrill and Watts demonstration that the NLRA and the Food Drug and Cosmetics Act, for example, are not properly viewed as such congressional delegations. See Merrill \& Watts, supra note 151. The Court might still conclude that it is too late to overrule precedents assuming the contrary, especially because Congress, the agencies, and the public have operated under this assumption for so long. But this is not an issue the Court should ignore, as it has done.

321. The statutes (including various amendments to them) are the Interstate Commerce Act of 1887 , the Securities Act of 1933, the Securities Exchange Act of 1934, the Communications Act of 1934, the Federal Power Act of 1934, the National Labor Relations Act of 1935, the Social Security Act of 1935, the Food Drug \& Cosmetics Act of 1938, the Federal Power Act of 1935, the Natural Gas Act of 1938, the Immigration \& Naturalization Act of 1952, the Medicaid Act of 1965, the Medicare Act of 1965, the Clean Air Act Amendments of 1970, the Federal Water Pollution Control Act Amendments of 1972, the Endangered Species Act of 1973, the Federal Labor Relations Act of 1978, the Natural Gas Policy Act of 1978, the Staggers Rail Act of 1982, the Sentencing Reform Act of 1984, and the Illegal Immigration Reform and Immigrant Responsibility Act of 1996.

322. Following the footsteps of Justice Frankfurter, his Harvard Law School predecessor on the Court, Justice Breyer often compiles neat appendices to his opinions. He or a colleague might usefully compile an appendix of statutes they (rather than just we) consider to have delegated lawmaking authority, with references to Supreme Court or lower court opinions properly applying Chevron under those circumstances.

323. From a rule-of-law perspective, the Scalia approach of affording Chevron deference to all interpretations adopted by the agency head (but not litigating positions) is preferable to the Barnhart criteria, unless the Court decides to eliminate Chevron as an independent category and subject all agency interpretations to Skidmore deference. Unfortunately, the constitutional and statutory problems we have identified with the Scalia approach disqualify it as the best rule-of-law alternative. 
delegation of lawmaking responsibility to agencies. Contrary to Mead's dicta, the Court should recognize no implicit delegations of lawmaking responsibilities to agencies, just as it does not recognize implicit congressional interference with the operations of state governments, abrogations of state sovereign immunity, or diminishment of the inherent powers of the federal judiciary and executive. ${ }^{324}$

We do not have a strong independent view of what the delegation rule ought to be, but we are inclined to agree with scholars who have argued that Chevron ought to be limited to delegations to agencies to engage in formal adjudication and notice-and-comment rulemaking. ${ }^{325}$ This bright-line rule is consistent with the APA (unlike other possible bright-line rules), would be relatively easy for both the Supreme Court and the courts of appeals to administer, and would give the Chevron boost to agency decisions that are relatively the most legitimate because of public inputs. The main drawback-and it is a big one-of this delegation rule is that agencies, thoughtful jurists, and many scholars believe that notice-and-comment rulemaking is "ossifying," "stultifying," or simply too resource-consuming to be cost-effective for many regulatory initiatives. ${ }^{326}$

We also endorse the approach the Court took in the Oregon Aid-in-Dying Case, which considered Chevron with attention to constitutional values. Read literally, the Controlled Substances Act seems to vest the Attorney General with considerable authority to revoke doctors' licenses to use drugs for what the Attorney General determines to be non-medical purposes. Such a broad reading of the Act would be inconsistent with the suggestion made by five Justices in Glucksberg that terminally ill patients sometimes have constitutionally protected privacy interests in exercising some control over the circumstances of their deaths. The Court might well uphold such a broad rule if Congress deliberated about the matter and specified it in the statute-but absent such action the Court was right to override the Attorney General. The Oregon Court was also bothered by the fact that the Attorney General was, effectively, preempting state law. Although the Court did not say so openly, we read Gonzales v. Oregon to reflect the Justices' application of an anti-deference regime informed by constitutional values.

Suggestion Three: Tie Skidmore Deference to Rule-of-Law, Agency-Expertise, and Legitimacy Considerations. Any agency interpretation that is not an act of delegated lawmaking should receive flexible Skidmore deference. The Skidmore opinion itself emphasized procedural features of agency action, such as thoroughness of consideration and consistency of application, but the overall

324. For discussion of these "clear statement" rules, see Eskridge \& Frickey, supra note 255, at $101-05$.

325. See, e.g., Bressman, supra note 32; Seidenfeld, supra note 278; see also Merrill \& Watts, supra note 151 (discussing various strategies the Court might follow in light of the delegation conventions Congress actually followed at various points in the twentieth century).

326. See, e.g., BreYer, supra note 285 , at 49; MASHAw \& HARFST, supra note 280 , at 224-54; McGarity, supra note 280; Pierce, supra note 280. 
point of Skidmore is that agency materials be evaluated for their "power to persuade." 327 We strenuously urge the Court to make clear that an agency's "power to persuade" under Skidmore be understood by reference to the substantive factors discussed in section III.B-especially comparative agency expertise: Is the issue a technical one where the agency has exercised intelligent expert judgment, based upon a factual connection between its choice and the (complex) statutory purpose? If so, there is greater reason for the Court to defer. This is the classic Chevron scenario, and it should be the core reason for Skidmore deference as well. In contrast, the Court in the Oregon Aid-in-Dying Case not only felt that the Attorney General displayed little expertise in setting medical practice rules, but pointed out that the statute vested this type of decisionmaking in HHS instead.

Also highly relevant is the level of public participation or feedback. Interpretations adopted after notice-and-comment rulemaking receive a big boost under this criterion - but so do regulations and guidances actively monitored by Congress. Even though they were not adopted pursuant to a delegation of lawmaking authority, HEW's Rehabilitation Act guidelines ought to receive strong Skidmore deference, as they did in Bragdon, because they were subjected to immediate and ongoing congressional oversight and were relied on by Congress when it adopted the ADA. Conversely, less Skidmore weight should attach to substantive policy stances adopted in low-visibility agency documents and guidances of the sort that Professor Nina Mendelson has recently identified and discussed. ${ }^{328}$

Finally, the level of Skidmore deference should consider rule-of-law factors. The agency sometimes has a lesson or two to teach the Justices about how to read the statute or make sense of its structure, but the primary rule-of-law variable will be reliance, which in turn is usually related to consistency in the agency's interpretation. Thus, a longstanding agency interpretation that regulated parties have internalized and that Congress has acquiesced in should rarely be overturned, a point made by the Court in several cases during the 2006 Term (and therefore not included in our empirical study). ${ }^{329}$ In contrast, a novel interpretation not well connected to statutory purpose or the evolution of the

327. Skidmore v. Swift \& Co., 323 U.S. 134, 140 (1944). We do not make a sharp distinction between a "power to persuade" reading of Skidmore and a "deference" reading of Skidmore. For a sharp distinction, see Hickman \& Krueger, supra note 32, at 1294-99.

328. Nina A. Mendelson, Regulatory Beneficiaries and Informal Agency Policymaking, 92 CORNELL L. REv. 397 (2007) (examining how the use of guidance documents affects the interests of regulatory beneficiaries and arguing for procedural reforms that would enable regulatory beneficiaries to engage in the agency's decisionmaking process); see generally Rakoff, supra note 264 (outlining the framework within which American administrative agencies are returning to informal administrative procedures and comparing American administrative procedures with other legal systems); Erica Seiguer \& John J. Smith, Perception and Process at the Food and Drug Administration: Obligations and Trade-Offs in Rules and Guidances, 60 FoOD \& DRUG L.J. 17 (2005) (examining rulemaking and guidance document development at the FDA).

329. See Watters v. Wachovia Bank, 127 S. Ct. 1559 (2007) (consultative-deference case where Court went along with longstanding agency interpretation against which Congress had amended the 
statute, such as the George W. Bush Administration's military commissions experiment (overturned in Hamdan), ought to receive less deference under Skidmore.

Thus, the Court should almost always go along with a longstanding agency interpretation upon which Congress had probably relied when it revisited the statute, that is supported by documented agency experience and expert opinion, and that was arrived at through a public process where the agency considered the arguments and evidence offered by affected interests. For example, the EEOC's Sexual Harassment Guidelines are not entitled to Chevron deference, but the Court has given them strong Skidmore deference for precisely these reasons. ${ }^{330}$ A recent Chevron example to the same effect is the Court's decision in Zuni Public School District No. 89 v. Department of Education. ${ }^{331}$ The Court upheld the Department of Education's formulae for determining state eligibility for reimbursement under the Federal Impact Aid Program. ${ }^{332}$ Although the statutory text concededly did not support the Department, the Court still Chevron-deferred because of the institutional history of the Department's functional rather than strictly textual reading of the statute. ${ }^{333}$ Specifically, the Department had adhered to its functional interpretation for two decades and had drafted the present statutory language, adopted by Congress, under the assumption that it codified its own consistent construction. ${ }^{334}$

On the other hand, the Court should give little or no weight to novel agency interpretations reaching matters as to which the agency has no particular expertise and where affected interests were not heard. The Ashcroft Directive fits this description well. In the Directive, the Attorney General displayed a shallow understanding of evolving medical thinking on aid-in-dying and presumed to occupy a field Congress had reserved for HHS; there was no public input regarding the Directive, nor even apparent consultation with more expert agencies and medical groups; the Directive was a striking departure from earlier Department of Justice deliberations on this and similar issues; and the Directive ran against congressional deliberation about-and rejection of-Senator Ashcroft's similar proposal in 199798. For these reasons, the Oregon Court was right to give the agency interpretation little weight on the Skidmore scale.

statute); Zuni Pub. Schs. Dist. No. 89 v. Dep't of Educ., 127 S. Ct. 1534, 1541 (2007) (Chevron deference case to same effect, but with stronger affirmative evidence of legislative approval).

330. See Farragher v. City of Boca Raton, 524 U.S. 775, 804 (1998) (accepting the EEOC Guidelines as settled law because of congressional acquiescence and developing liability rules for employers); Meritor Sav. Bank v. Vinson, 477 U.S. 57, 65 (1986) (adopting the EEOC's legal structure).

331. 127 S. Ct. 1534 (2007).

332. Id. at 1546.

333. Id. at $1540,1544-45$.

334. Id. at 1541 . 
3. New Procedural and Structural Suggestions That Might Facilitate Court-Agency Cooperation

Suggestion One: Solicitation of Agency Views. A largely unremarked feature of the Court's deference jurisprudence is the extent to which the Justices have solicited agency inputs, usually through requests for amicus briefs. Sometimes, in fact, the Supreme Court insists upon lower court solicitation of agency views. In Mead Corp. v. Tilley, for example, the Court deferred to Department of Labor guidelines for interpreting ERISA, but remanded to the lower court with instructions to solicit more guidance from the Department. ${ }^{335}$

Expanding upon Tilley, our suggestion is that the lower courts should be encouraged to solicit agency views more often than they do, especially in labor, pension, civil rights, bankruptcy, and other areas where the Supreme Court often follows a consultative deference approach. Until the publication of this Article, there was no reason lower courts should have been aware that the Court relies so strongly on Solicitor General amicus briefs in these areas. With the publication of our empirical study, lower courts are now on notice and ought to adjust their practices, including in their options the solicitation of federal executive viewpoints. This would make the operation of the federal judiciary more efficient at resolving legal issues.

There is a speculative "cost" that should be investigated and considered by the Supreme Court as well as lower courts. The cost is that the Court might be influenced too much by the Solicitor General's Office, excellent as it is. Agencies complain, sometimes bitterly, that the Solicitor General often does not represent their expert judgments and sometimes pushes aside their informed viewpoints without sufficient legal justification. We do not know how serious this problem is, though it is one that has persisted across different administrations. ${ }^{336}$ Presumably, the Solicitor General's inattention to agency expertise is less serious in cases where there is a formal agency action-a rule, a policy guidance, an adjudicated order, perhaps even an official agency manual. Although the Solicitor General sometimes abandons agency positions he thinks erroneous, the existence of such rules tethers the Solicitor General's submissions to the agency's perspective-in contrast with amicus briefs, answering an issue the agency has not publicly addressed.

Another potential cost is that the Court's reliance on federal agency inputs might distort statutory law in ways that might not be in the national interest. In bankruptcy cases, for example, executive department amicus briefs tend to favor creditors' interests, because the United States is itself often a creditor in bankruptcy. In Rash, for example, the Court followed the Solicitor General to choose the most pro-creditor rule for valuing debtor-retained property in bank-

335. 490 U.S. $714,725-26(1989)$.

336. Professor Peter Strauss, a former agency official and one of the top administrative law professors of the twentieth century, pressed this point upon us in comments he made at our Fall 2006 workshop at the Columbia School of Law and in follow-up conversations. 
ruptcy, even though most of the courts of appeals (including the respected Second and Seventh Circuits) had rejected that rule. ${ }^{337}$ As Seventh Circuit Judge Easterbrook argued, such a rule is neither economically justified nor required by the statutory text or structure. ${ }^{338}$

Judicial deference to agency inputs would press criminal, antitrust, and securities law toward expanded liability (the Kentucky Kickback Case), national security law toward greater executive authority over individuals (the Military Commissions Case), and voting rights, banking, and health and safety law toward increased preemption of state regulation (the Oregon Aid-in-Dying Case). In the noted cases, the Court resisted executive department pressure, but that is the exception and not the rule. We leave to the gentle reader her own judgment as to whether the law is being unbalanced in some areas. If she thinks so, what is the solution? After study, the Judicial Conference should seek congressional funding for personnel within the judicial branch (perhaps an office) that could provide independent analysis for the Supreme Court and perhaps lower courts on technical issues, where the Solicitor General has an effective monopoly today.

Suggestion Two: Signaling Future Deference. In statutory areas where Congress has granted an agency lawmaking authority but the agency has not exercised that authority, the Court should not evaluate the agency input under the Chevron criteria, though it can signal to the agency that its interpretation is potentially Chevron-eligible. We found examples in our dataset. For a dramatic example, the Army Corps of Engineers has been delegated authority to adopt rules for preserving environmental quality and habitats in and around the "waters of the United States." ${ }^{339}$ Reflecting green politics, the Corps adopted regulations protecting the nation's "wetlands,"340 which the Supreme Court upheld in $1985 .{ }^{341}$ In Rapanos v. United States, ${ }^{342}$ the Court held that the Corps had gone too far when it construed its wetlands regulations to include spaces far from the nation's waterways, but Chief Justice Roberts (in a concurring opinion) and Justice Breyer (in dissent) urged the Corps or the EPA to revisit the issue through legislative notice-and-comment rulemaking. ${ }^{343}$

337. Assocs. Commercial Corp. v: Rash, 520 U.S. 953, 958-59 (1997) (abrogating In re Hoskins, 102 F.3d 311 (7th Cir. 1996) and In re Valenti, 105 F.3d 55 (2d Cir. 1997)).

338. In re Hoskins, 102 F.3d at 317, 319 (Easterbrook, J., concurring in judgment), abrogated by Rash, 520 U.S. 953; accord Rash, 520 U.S. at 966-67 (Stevens, J., dissenting).

339. 33 U.S.C. $\S \S 1344(a), 1362(7)(2000)$.

340. 33 U.S.C. § 328.3(a)(2) (2000).

341. United States v. Riverside Bayview Homes, Inc., 474 U.S. 121 (1985),

342. 126 S. Ct. 715 (2006).

343. Id. at 2236 (Roberts, C.J., concurring); id. at 2266 (Breyer, J., dissenting). For other cases where concurring Justices have made similar pitches, see, for example, Norfolk S. Ry. v. Shanklin, 529 U.S. 344 (2000) (Breyer, J., concurring); Christensen v. Harris County, 529 U.S. 576, 589 (2000) (Souter, J., concurring); United States v. Watts, 519 U.S. 148, 158-59 (1997) (Breyer, J., concurring). But see id. at 158 (Scalia, J., concurring) (rejecting Breyer's position that the Court's opinion posed no obstacle to the Sentencing Commission reversing the case's outcome because the statute was clear and therefore allowed no agency flexibility). 
In several other cases, Court majorities have overruled agency interpretations but openly invited agencies to respond with notice-and-comment rulemaking. ${ }^{344}$ This is a practice that we should encourage. For cases where Congress has delegated an agency lawmaking authority (usually through substantive rulemaking) but the agency has not availed itself of that mechanism, the Court should avoid unduly broad interpretations of the statute and should explicitly discuss the extent to which its analysis precludes agency rulemaking at some future date. We also strongly support the Court's occasional practice of granting review, vacating the judgment below, and remanding to the lower court ("GVR" orders) when an agency generates or is generating a substantive rule to which the lower court should probably Chevron-defer. ${ }^{345}$

This practice is a partial response to concerns about statutory ossification. For the broad swaths of law where Congress has delegated agencies lawmaking authority, the Court should guard against hard-wiring its own constructions into a statute and should more often recognize that its Skidmore-ish all-thingsconsidered take on a statutory issue can be reversed by an agency acting under congressional delegations. Indeed, we would go so far as to propose, for the Court's consideration, a presumption that the Court's Skidmore-inflected interpretations of statutory texts should be reversible by agencies if the interpretation falls within the domain of issues where agency rules are potentially entitled to Chevron deference.

Suggestion Three: Attention to Historical and Factual Materials. In a democracy, we are nervous that rules adopted by our elected representatives are being updated by unelected and perhaps unaccountable officials. ${ }^{346}$ Agents interpreting and applying the legislation may "distort" its meaning because they have a non-public-regarding agenda. Those usurpative agents might be administrative agencies, but they might also be judges. We believe that foxes ought not guard henhouses. But how can we tell the foxes from the guardians? Isn't there a risk that any judicial monitoring of agency updating will merely substitute one set of foxes (namely, unelected biases) for another? Over time, the pas de deux between foxes in the agencies and foxes on the bench may press the statute further and further from its original legitimating expectations and purposes.

The Oregon Aid-in-Dying Case illustrates that fear. The Justices who are most firmly pro-life in their personal viewpoints fought every legal conclusion with the fierceness of a tigress protecting her cubs. The Justices who are most friendly to constitutional protection of death with dignity joined the opinion of the Court without cavil, even though it did not answer all the cogent legal

344. See, e.g., Pharm. Research \& Mfrs. v. Walsh, 538 U.S. 644 (2003); Nw. Airlines, Inc. v. County of Kent, Mich., 510 U.S. 355, 368 n. 14, 374 (1994).

345. See, e.g., Lawrence v. Chater, 516 U.S. 163, 171 (1996) (per curiam).

346. Cf. Bressman, supra note 32, at 462-63 (urging administrative law to get past the countermajoritarian anxiety); see generally AleXander M. Bickel, The Least Dangerous Branch: The Supreme Court at the Bar of Polmtics (1962); Barry Friedman, The Birth of an Academic Obsession: The History of the Countermajoritarian Difficulty, Part Five, 112 YALE L.J. 153 (2002). 
objections raised by the dissenters. Examine your own reaction to the arguments in the case: Didn't you cheer the arguments of the side you agree with, while questioning the good faith of the Justices and officials on the other side? If you did, you are altogether human, but re-read the opinions and see if you do not agree with us, that each side advanced excellent legal arguments that could be persuasive to a neutral observer.

As Tables 20 and 21 reveal, the pattern we found in the Oregon Aid-in-Dying Case can be generalized. With the exception of Justice Powell, ${ }^{347}$ Justices with socially conservative or business-oriented backgrounds and appointed by conservative Republican Presidents voted with the agency much more often when the agency reached a conservative result than when the agency reached a liberal result. With the exception of Justice White, ${ }^{348}$ Justices with public-service or plaintiff-oriented backgrounds and appointed by moderate Republican or Democratic Presidents voted with the agency much more often when the agency reached a liberal result than when the agency reached a conservative result.

The overall pattern, revealed most starkly in Table 21, will not surprise academics. ${ }^{349}$ And few of us believe that ideological voting means the end of democracy. Indeed, we are inclined to think that our survey reveals a surprisingly modest amount of ideological voting. In the two decades of cases we examined, the Supreme Court's docket has shrunk by half. The selection effect of having fewer circuit splits, to which Chevron has probably contributed, suggests to us that the "missing half" of the Court's 2005 Term docket would have yielded much less ideological voting among the Justices. Compared with the Chevron Court in 1984, the Hamdan Court in 2006 may actually be less ideological.

Nonetheless, ideological voting does persist. And, for the reasons suggested above, our culture fears that the rule of law itself will be undermined if unelected judges have their fingers on the scales when they decide cases. (We the People expect agencies, but not judges, to consider "political" factors.) So once ideological voting is documented for the Supreme Court, it becomes a problem to be managed.

Most academics who have addressed this topic seem quite certain that the proper judicial methodology will reduce or eliminate judicial discretion to override agencies. For example, John Manning and Adrian Vermeule maintain that if judges follow the plain-meaning rule they will tend to leave agencies

347. Justice Powell was only one of three Justices during our survey period who did not serve as a judge before appointment to the Court.

348. Like Justice Powell, Justice White also had no judicial experience before appointment to the Court. He is unique among our collection in that his voting in the period from 1984-93, when he retired, was the opposite of his political affiliation, New Frontier Kennedy Democrat.

349. Indeed, the dominant, almost monopolistic, political-science model is that the Justices' votes are determined only or primarily by ideology. See, e.g., LeE EPSTEIN \& JACK KNIGHT, The Choices Justices Make (1998); Jefrrey A. Segal \& Harold J. Spaeth, The Supreme Court and the Attitudinal Model (1993); see also Theodore W. Ruger \& Pauline T. Kim, The Supreme Court Forecasting Project, 104 Colum. L. Rev. 1150, 1163-71 (2004). 
alone $^{350}$ or will at least follow the politically neutral approach of a faithful agent of the original congressional majority. ${ }^{351}$ Vermeule and Manning would surely say that no one better epitomizes the predictable rule of law than Justice Scalia, for whom both clerked. We are agreeable to that proposition-yet even the nation's most outspoken rule-of-law jurist agreed with conservative agency interpretations at a significantly higher level than with liberal agency interpretations. Using a different methodology, Thomas Miles and Cass Sunstein found that Justice Scalia's agreement rate with Clinton Administration agency cases was significantly lower than his agreement rate with those supported by the George W. Bush Administration. ${ }^{352}$ So even the best of the textualists reveals ideological voting. Moreover, the other strong textualist on the RehnquistRoberts ,Courts, Justice Thomas, has the second largest ideological gap in his agreement rates among all the currently serving Justices. ${ }^{353}$ It is not credible to think that the plain-meaning rule exercises any constraint on his decisions.

James Brudney and Corey Ditslear argue that consulting legislative history offers a better method for constraining judges than the new textualism, and unlike the previously discussed legal academics they support this theory with empirical data. Surveying almost a generation of the Court's labor cases, Brudney and Ditslear found that consultation of legislative history had a moderating effect on the more liberal Justices. ${ }^{354}$ We have not tested for a similar pattern in our own (incomplete examination of our) data, but it is noteworthy that the biggest user of legislative history on the current Court, Justice Stevens, reveals the most ideologically polarized voting pattern. (Everyone on the Burger Court relied lavishly on legislative history, including the highly deferential and less ideological Justices White and Powell as well as the undeferential and highly ideological Justices Brennan and Marshall.) Nonetheless, because the Brudney-Ditslear theory does have some empirical support in the labor cases, we consider it a plausible approach, unlike that of Vermeule and Manning.

Finally, Cass Sunstein believes that "nondelegation" canons of statutory construction will constrain executive as well as judicial officials in the new

350. See Vermeule, supra note 199, at 1-3, 12 (arguing for a no-frills textualist approach by federal judges that would leave virtually all statutory gapfilling to agencies).

351. See John F. Manning, Textualism as a Nondelegation Principle, 97 CoLum. L. Rev. 673, 738-39 (1997) (arguing that, to avoid legislative self-delegation problems, federal courts should apply a strict textualist approach that does not treat legislative history as authoritative).

352. See Miles \& Sunstein, supra note 38 , at 879.

353. See id. at 880; Table 21 supra.

354. See James J. Brudney \& Corey Ditslear, The Decline and Fall of Legislative History? Patterns of Supreme Court Reliance in the Burger and Rehnquist Eras, JUdiCATURE, Jan.-Feb. 2006, at 220, 226-27 (finding that reliance on legislative history had a moderating influence on liberal Justices in labor cases); James J. Brudney \& Corey Ditslear, Liberal Justices' Reliance on Legislative History: Principle, Strategy, and the Scalia Effect 26-27 (Ohio State Univ. Moritz College of Law Pub. Law \& Legal Theory Working Paper Series, Paper No. 95, 2007), available at http://ssm.com/abstract $=1008330$ (providing a more detailed examination of the evidence). 
post-Chevron era. ${ }^{355} \mathrm{We}$ are dubious, in large part because the canons are (in)famously numerous and manipulable, by agencies as well as judges. Thus, one of Sunstein's favorite canons-the avoidance of serious constitutional questions - was a key argument posed by the Office of Legal Counsel to justify the legality of executive torture of detained persons, as Trevor Morrison has just reminded us. ${ }^{356}$ Importantly, there is no evidence - and our study did not come up with anything helpful-that the canons operate as constraints on judicial decisionmaking. To the contrary, Brudney and Ditslear found, as an empirical matter, that conservative Justices have deployed canons of construction to trump legislative expectations and to justify reading their pro-employer preferences into American labor law. ${ }^{357}$ Thus, not only is a canons approach not constraining, but the only empirical evidence now available suggests that the canons are applied in a way that liberates Justices from the possible restraints that legislative history might impose.

The existing evidence does not give us much hope that some "method" of interpretation will reduce (much less end) ideological voting among the Justices. Our strategy would be institutional and informational. Institutionally, an informal coalition of Justices ought to coalesce around an informational strategy. ${ }^{358}$ The reason textualist and canonical methods do not constrain judges is because these sources are too thin to overwhelm judicial preconceptions. A pro-life judge reading the CSA's provision that the Attorney General should not register doctors prescribing drugs in a manner not in the "public interest" is of course going to assume that "assisted suicide" is banned; a death-with-dignity judge will not, however many dictionaries or canons you ply her with. The main reason we think legislative history sometimes has some traction is that it provides judges with a thicker context for the statute that offers greater chance of supplanting the judge's own preconceptions. Our hypothesis is that Justices critically reading legislative materials in addition to statutory text will be better attuned to the agenda of Congress, and less prone to fall into their own agenda, than Justices who just read statutory text and then play with it.

355. See Sunstein, supra note 205, at 2607-10.

356. See Trevor Morrison, Constitutional Avoidance in the Executive Branch, 106 Colum. L. REv. 1189, 1193-94 (2006) (discussing the Yoo Memorandum justifying the legality of executive branch torture).

357. Brudney \& Ditslear, supra note 40 , at 59-63.

358. Interestingly, Justices Breyer, Ginsburg, Souter, Kennedy, and Scalia-clustered together in the middle of Table 21, supra - were students in the Hart and Sacks course on The Legal Process in the late 1950 s and early 1960 s. The Hart and Sacks project aimed to facilitate the neutral operation of good government through reasoned elaboration by agencies and courts. Although they have wildly different personal and even writing styles, these five students of Hart and Sacks love the rule of law, carefully follow precedent, are dedicated students of the administrative and legislative process, and believe that agencies should take the lead in developing the contours of statutory policy. In this spirit, we offer a challenge to the new Chief Justice, who is himself familiar with Hart and Sacks's work: help foster a nonpartisan center of the Court that will reinvigorate statutory interpretation and agency lawmaking in the modern administrative state. 
This is why the survival and flourishing of Skidmore can be just as useful as Chevron, if not more so. There is a danger of too much Chevron formalism, where big-issue cases become pitched battles over Chevron Step 0; this is an important reason for the Court to settle on a bright-line rule, clearly announce what is eligible and what is not, and then stick to it. An advantage of a Chevron regime limited to legislative rulemaking is that the agency always has to earn its deference. To be Chevron-eligible, a boon even if of indeterminate importance, the agency usually has to make law through notice-and-comment rulemaking and therefore provide evidence supporting its rule and respond to alternatives. If not Chevron-eligible, the agency has to be persuasive to earn its stripes under Skidmore. To be persuasive, the agency has to say more than "we have viewed the statute this way from the beginning." The agency has to provide useful and factual information about the legislative history of the statute and its evolution, successful ways to handle statutory risks and meet statutory purposes, experiments that have been tried (perhaps at the state level or abroad), professional consensus and expert reports, and so forth.

\section{CONCLUSION: RETHINKING STATUTORY INTERPRETATION IN THE MODERN ADMINISTRATIVE STATE}

Most of the cases discussed in this Article illustrate the inevitability of dynamic statutory interpretation and the ways this inevitability plays out in the modern administrative state. ${ }^{359}$ As reflected in cases from Chevron to Hamdan, the primary engine of statutory dynamism is and long has been agencies, with courts as second-level interpreters (if that) in most instances. ${ }^{360}$ In our view, the constant stream of agency-generated law, interpretations, factual materials, and policy analyses digested by courts in the last three generations has changed (and ought to have changed) the way judges approach statutory interpretation. ${ }^{361}$ Consider a few of the arenas where we think the Supreme Court has benefited from its interaction with agency interpretations.

Legislative History. Traditionally, judges and scholars have justified resort to legislative history as a means of discerning the "intent" of the legislators who

359. The theoretical bases for the inevitability of dynamic statutory interpretation are discussed in WILlam N. ESKRIDGE, JR, DyNAMIC STATUTORY INTERPRETATION, at ch. 2 (1994), and applied to various problems in id. chs. 1 and 3. See also Adrian Vermeule, Dynamic Statutory Interpretation and the Institutional Turn 1-13 (Berkeley Electronic Press, Issues in Legal Scholarship, Art. No. 3, 2002), available at www.bepress.com/ils/iss3/art3.

360. See Edward Rubin, Dynamic Statutory Interpretation in the Administrative State 13 (Berkeley Electronic Press, Issues in Legal Scholarship, Art. No. 2, 2002), available at www.bepress.com/ils/iss3/ art2; Jerry Mashaw, Agency Statutory Interpretation, 9 (Berkeley Electronic Press, Issues in Legal Scholarship, Art. No. 9, 2002), available at http://www.bepress.com/ils/iss3/art9; accord EsKRIDGE, supra note 359 , at ch. 4.

361. Cf. Edward L. Rubin \& Malcolm M. Febiey, Judicial Policy Making and the Modern State: How the Courts Reformed America's Prisons 1-4, 20-25 (1998) (arguing that judicial handling of public-interest class actions and constitutional law needs to borrow ideas from judicial handling of administrative law). 
enacted the statute. The intent might be the specific meaning the legislators expected their statute to carry with $i^{362}$ or the more general purposes the legislators were trying to accomplish with the statute. ${ }^{363}$ From all these perspectives, legislative history is archaeological: it enables the interpreter to understand the statute as its drafters and enacters understood it at the time of enactment. Because they are often involved in statutory drafting and congressional deliberations, agencies usually know the legislative history very well, and their briefs provide the statutory archaeologist with excellent material, albeit slanted in favor of the agency's interpretation.

Agency briefs also deploy legislative history in a dynamic manner, to recount the life of the statute and not just its birth. Although the Solicitor General's brief in the Oregon Aid-in-Dying Case came up with some excellent originalmeaning arguments from the pre-history of the CSA, ${ }^{364}$ most of its discussion of legislative history involved post-1970 developments, including legislative history of the 1974 and 1984 amendments to the CSA $^{365}$ and numerous federal statutes establishing national standards for legitimate medical practice. ${ }^{366}$ Thus, the government's briefs in Gonzales v. Oregon revealed an evolving understanding of the CSA as something more than merely a law that criminalized drug crimes; over the years, the Department and Congress came to see it as a situs for an agency-based federal common law of legitimate medical deployment of scheduled substances. ${ }^{367}$

One might readily suppose that this kind of "subsequent legislative history" simply marks the contrast between administrative and judicial approaches to statutory interpretation, and that has been the official line of the post-1969 Supreme Court. But, in fact, both pre- and post-1969, the Court deployed ongoing legislative history to support statutory interpretations - usually in cases where the Court was assimilating agency understandings of statutes that had generated ongoing exchanges between the agency and Congress. ${ }^{368}$ In the

362. See, e.g., United Steelworkers v. Weber, 443 U.S. 193, 230-51 (1979) (Rehnquist, J., dissenting) (relying on legislative history to demonstrate that the critical supporters of Title VII did not intend to allow even "voluntary" affirmative action programs).

363. See, e.g., id. at 201-04 (Brennan, J.) (relying on legislative history to demonstrate that Title VII's general purpose was not to prohibit private and voluntary affirmative action efforts); HART \& SACKs, supra note 311 , at $1377-80$ (criticizing resort to legislative materials to determine specific intent, but admitting them to learn the general purpose of the statute).

364. See, e.g., Brief for Petitioners at 19-20, Gonzales v. Oregon, No. 04-623 (May 12, 2005) (arguing astutely that the Supreme Court had interpreted prior federal criminal statute regulating dangerous drugs not to allow doctors to use morphine to ease a patient's pain and presuming that Congress acquiesced in such interpretation when it adopted the CSA in 1970).

365. Id. at $34-35,48$.

366. Id. at $42-43$.

367. See id. at $34-48$.

368. See, e.g., FDA v. Brown \& Williamson Tobacco Corp., 529 U.S. 120, 122 (2000) (rejecting FDA assertion of jurisdiction over tobacco products in light of repeated FDA representations to Congress that it did not have such jurisdiction); Farragher v. City of Boca Raton, 524 U.S. 775, 792 (1998) (following EEOC interpretation of Title VII to protect against workplace sexual harassment, based upon congressional ratification of the idea); Babbitt v. Sweet Home, 515 U.S. 687, 702 (1995) 
Oregon Aid-in-Dying Case, for example, the majority opinion gave some emphasis to the facts that Congress assumed in 1974 that HEW and not the Department of Justice would take the lead in making medical decisions, ${ }^{369}$ followed that assumption in a 1978 statute, ${ }^{370}$ created in 1984 a five-factor test (including reliance on state law) to be applied to deregister doctors, ${ }^{371}$ relied on statutory amendment rather than executive action to expand the CSA in 1990 to include some drugs that are not addictive or psychotropic (for example, steroids), ${ }^{372}$ and in 1999 rejected the proposal to preempt Oregon's death-withdignity law when Ashcroft presented it as a Senator. ${ }^{373}$

In our view, attention to the ongoing legislative history of a statute is often going to be useful information for courts evaluating agency rules and interpretations. At the very least, such evidence provides the Court with valuable information about public and sometimes private reliance on or acquiescence in agency interpretations. It also provides the Court with useful information about the possible political consequences of disagreeing with the agency. The Supreme Court suffered needless humiliation when it dismissed serious agency views about the proper meaning of the nation's civil rights laws in pregnancy discrimination cases of the $1970 \mathrm{~s}$ and race discrimination cases of the $1980 \mathrm{~s}^{374}$

Stare Decisis for Statutory Precedents. Courts take stare decisis seriously, both to save themselves the effort of revisiting prior decisions and to reassure the citizenry that legal rules are stable. Traditionally, stare decisis has been considered virtually sacrosanct in statutory cases, so that the responsibility for correcting judicial mistakes will be understood as lying solely with Congress. ${ }^{375}$ As with legislative history, this commitment to stare decisis is understood as a feature fundamentally distinguishing court from agency statutory construction. Thus, in the Oregon Aid-in-Dying Case, the majority went to great pains to justify its narrowing interpretation in light of precedent and to distinguish precedents that had construed the CSA's ambit liberally. ${ }^{376}$ Conversely, dissenting Justices scored important points by arguing that the Ashcroft Directive's national standard barring the use of scheduled drugs for "assisted suicides" is consistent with the Supreme Court's reading of the CSA in recent constitutional

(following Department of Interior interpretation of Endangered Species Act, based on subsequent congressional ratification of the agency's highly dynamic interpretation); Bob Jones Univ. v. United States, 461 U.S. 574, 599 (1983) (following IRS interpretation of Code to deny tax exemption to racially discriminatory schools, based upon congressional acquiescence in the controversial agency interpretation).

369. Gonzales v. Oregon, 546 U.S. 243, 265 (2006).

370. Id. at 266 (invoking Congress's implementation of the Psychoptropic Substances Convention, 21 U.S.C. \& $801 \mathrm{a}(3)(2000))$.

371. Id.

372. Id. at 273 (relying on the Anabolic Steroids Control Act of 1990, Pub. L. No. 101-647 § 1902, 104 Stat. 4851 (1990)).

373. Id. at 253.

374. See supra notes $297-99$ and accompanying text.

375. See William N. Eskridge, Jr., Overruling Statutory Precedents, 76 Geo. L.J. 1361, 1362 (1988).

376. Oregon, 546 U.S. at 269 (distinguishing United States v. Moore, 423 U.S. 122 (1975)). 
cases. $^{377}$

The modern administrative state has greatly undermined this distinction between courts religiously applying precedent and agencies free to roam from one interpretation to another. As a theoretical matter, it must be recognized that the rule of law depends on horizontal as well as vertical coherence-the consistency of a rule with other norms and rules in society today (horizontal), as well as the rule's consistency over time (vertical). Now that agencies are the primary articulators of legal rules and interpretations, they have recognized the value of vertical consistency - but at the same time the Supreme Court has bowed explicitly to the value of horizontal consistency and has recognized that stare decisis creates risks of legal ossification. This has been explicit in the Court's Chevron jurisprudence. Chevron itself recognized that agency rulemaking "must consider varying interpretations and the wisdom of its policy on a continuing basis." 378

The implication of Chevron is that a Supreme Court decision deferring to an agency interpretation does not create a stare decisis effect for that interpretation. Because there is a zone of indeterminacy in the statutory command, any reasonable agency interpretation within that zone ought to be acceptable, and so the stare decisis effect of the Supreme Court's decision is minimized. In National Cable \& Telecommunications Ass'n v. Brand X Internet Services, for the best recent example, the Court held that a prior lower court construction of an ambiguous statute was not a bar to the agency's formulation of a rule to the contrary. ${ }^{379}$ Because Brand $X$ involved notice-and-comment rulemaking, the agency was required to consider the previous interpretation and to provide plausible reasons why the statute should be interpreted in another way. ${ }^{380}$

$B$ rand $X$ represents an understanding of stare decisis as a process of ongoing elaboration or experimentation that we should extend beyond the facts of Brand $X$ and the Court's Chevron jurisprudence. Consider an example from the Skidmore-Lite category in our deference continuum. The Court periodically revisits and overrules its Sherman Act precedents with rarely a mention of the super-strong presumption of correctness of statutory precedents. The reason for the periodic overrulings is that expert evaluation of many of the older precedents suggests that they burden market decisions without any discernible benefit for consumers (the Court's current understanding of the Sherman Act's purpose). The Court does not lightly cast aside these precedents-in fact it usually

377. Id. at 299-301 (Thomas, J., dissenting) (criticizing the majority's departure from the broad interpretation the Court gave the CSA in Gonzales v. Raich, 545 U.S. 1 (2005)).

378. Chevron U.S.A., Inc. v. Natural Res. Def. Council, 467 U.S. 837, 863-64 (1984). For a powerful statement of the effect that Chevron should have on stare decisis, see United States v. Mead Corp., 533 U.S. 218, 231-41 (Scalia, J., dissenting).

379. 545 U.S. 967, 968-69 (2005); see id. at 1019 (Scalia, J., dissenting) (urging a broader rethinking of stare decisis in agency-interpretation cases).

380. See Motor Vehicle Mfrs. Ass'n v. State Farm Mut. Auto. Ins. Co., 463 U.S. 29, 43 (1983) (setting forth arbitrariness criteria for judicial review of notice-and-comment rulemaking). 
does so only after the FTC and the Department of Justice's Antitrust Division formally suggest an overruling in an amicus brief. ${ }^{381}$

We should urge the Court to generalize its Sherman Act jurisprudence, at least somewhat. Typically, when the Court overrules a Sherman Act precedent, it is rejecting an interpretation that originated in a Justice Department or FTC prosecution during the $1950 \mathrm{~s}$ and $1960 \mathrm{~s}$ - and it is doing so at the behest of the same agencies, which have now concluded that the earlier, more aggressive approach to the Sherman Act did not serve its consumer-welfare purpose. (We emphasize that neither the agencies nor the Court comes to such conclusions lightly; the process of reconsideration and then overruling usually proceeds over ten years or more.) Likewise, the Supreme Court should be willing to revisit other kinds of precedents when the agency that helped persuade the Court of the cogency of one reading under Skidmore has come to a new and deeply considered conclusion that is at odds with the old precedent. Although we have found a couple of overrulings where this course of action was probably misguided, ${ }^{382}$ this pattern of experience and critique/agency proposal/judicial response is a model for how our legal system can evolve in a manner that is both responsive to learning and experience, yet also orderly and respectful of reliance interests.

Substantive Canons of Statutory Construction. Traditionally, scholars and judges have justified the substantive canons of statutory interpretation as either rules that reflect likely legislative preferences ${ }^{383}$ or as mechanisms to place the burden of deliberating about constitutional or other fundamental norms on Congress. ${ }^{384}$ Justice Kennedy's opinion for the Oregon Court declined to invoke "clear statement requirements" or "presumptions," but instead invoked the federalism and nondelegation values underlying those canons as "background

381. See, e.g., State Oil Co. v. Khan, 522 U.S. 3 (1997), overruling Albrecht v. Herald Co., 390 U.S. 145 (1968). But see Square D Co. v. Niagara Frontier Tariff Bureau, 476 U.S. 409, 424 (1986) (rejecting the Department of Justice's suggestion that the Court overrule Keogh).

382. The Supreme Court's opinion in Wards Cove Packing Co. v. Atonio, 490 U.S. 642 (1989), closely followed the views of Solicitor General Charles Fried to cut back and narrow Griggs v. Duke Power Co., 401 U.S. 424 (1971), where the Court had closely followed the views of Nixon Administration Solicitor General Erwin Griswold. Together with several decisions where the Court unwisely rejected moderate readings offered by Solicitor General Fried, Wards Cove generated the proverbial "firestorm of protest" and an angry congressional override. See Civil Rights Act of 1991, Pub. L. No. 102-166, 105 Stat. 1074. For another decision that strikes us as open to question, see Leegin Creative Leather Products v. PSKS, Inc., 127 S. Ct. 2705 (2007), overruling Dr. Miles Medical Co. v. John D. Park \& Sons Co., 220 U.S. 373 (1991).

383. See, e.g., SCALIA, supra note 276, at 25 (1997); Einer Elhauge, Preference-Estimating Statutory Default Rules, 102 Colum. L. Rev. 2027, 2051 (2002); Geoffrey Miller, Pragmatics and the Maxims of Interpretation, 1990 WIS. L. REv. 1179, 1186. Compare the "gap-filling" role scholars find for many default rules in contract interpretation. See, e.g., Alan Schwartz, The Default Rule Paradigm and the Limits of Contract Law, 3 S. CAL. INTERDISC. L.J. 389, 390 (1993).

384. See, e.g., Eskridge \& Frickey, supra note 224, at 597; Einer Elhauge, Preference-Eliciting Statutory Default Rules, 102 Colum. L. Rev. 2162, 2164 (2002). Compare the "equilibrium-inducing" role scholars have attributed to some default rules in contract interpretation. See Ian Ayres \& Robert Gertner, Strategic Contractual Inefficiency and the Optimal Choice of Legal Rules, 101 YALE L.J. 729 (1992). 
principles." They "belie the notion that Congress would use such an obscure grant of authority to regulate areas traditionally supervised by the States' police power." 385

More recently, scholars have suggested that the substantive canons should be baselines designed to serve the purposes of the modern regulatory state, as by giving voice to under-represented voices or correcting for dysfunctions in the political process. ${ }^{386}$ Reflecting a different kind of normative canon, the theme of the government's brief in the Oregon Aid-in-Dying Case revolved around the strong "presumption in favor of a uniform national standard" to implement regulatory statutes. ${ }^{387}$ What both academics and the government add to the prior thinking is that the substantive canons are relentlessly normative and not just positive. They deeply involve issues of policy and value. Insofar as the substantive canons reflect policy judgments, agency inputs are valuable but ought not be dispositive.

Agency practice is driven by one substantive canon above all others: advance the interpretation that best advances the statutory purpose (so long as the statutory text can accommodate that interpretation). ${ }^{388}$ This canon, for example, animated Attorney General Ashcroft's Directive, which read the CSA as creating national rules regulating the use of drugs that Congress or the Attorney General has designated as dangerous. Ashcroft also read the CSA as vesting him with discretion to determine what exactly is meant by dangerous and what the public interest requires-hence the ban against "medical" use of drugs to induce death. Oregon also helps us see how the process of interpreting-from-purpose is doubly normative. The Attorney General was not only reasoning from a statutory norm, but his application of that norm to the problem of "assisted suicide" (as he termed aid-in-dying) changed the norm itself. ${ }^{389}$ Before the Directive, the CSA's almost-exclusive focus was the abuse of hallucinogenic or psychotropic drugs. What the Ashcroft Directive brought into focus is that many of the scheduled drugs were not just potentially fatal, but could be used to induce fatality, and the Attorney General read the statute as regulating that, too. Rejecting Ashcroft's reading, the Supreme Court majority judged that this was too severe and problematic a reworking of the statutory purpose. As the

385. Gonzales v. Oregon, 546 U.S. 243, 274 (2006).

386. See, e.g., EsKRIDGe, supra note 359, at 49; CASS R. SunsteIn, After tHE Rights Revolution: Reconceiving the Regulatory State 161 (1990). Compare the "normative" or "transformatory" default rules some scholars have attributed to some default rules in contract interpretation. See, e.g., Jedediah Purdy, The American Transformation of Waste Doctrine: A Pluralist Interpretation, 91 CoRNELL L. REv. 653, 667 (2006) (praising “transformatory" default rules); Schwartz, supra note 383, at 393 (criticizing "normative" default rules in contract interpretation).

387. Brief for Petitioners at 25, Gonzales v. Oregon, No. 04-623 (May 12, 2005).

388. This agency-based canon is the Hart and Sacks formula, HART \& SACKS, supra note 311, which was inspired by Henry Hart's service in the Office of Price Administration during World War II. See id. at $l i$ (critical introduction by William N. Eskridge, Jr. and Phillip Frickey).

389. On the endogeneity of reasoning from purpose, see RicHARDSON, supra note 185; William N. Eskridge, Jr. \& Gary Peller, The New Public Law Movement, 89 Mich. L. Rev. 707, 747-49 (1992). 
dissenters correctly observed, this judgment was one of constitutional policy as much as statutory interpretation. What the majority probably appreciated was that the same thing can be said of the dissents.

The Oregon Aid-in-Dying Case also illustrates how the Court's substantive canons serve institutional goals as well as normative ones (and of course the two are related). Even when canons like the rule of lenity and the presumption against preemption of traditional state functions are subtly invoked, as they were in Oregon, they are laying out rules of the game reminding this agency, and all the other agencies, that the Supreme Court will jealously protect its Marbury role as guardian of the nation's constitutionalism, including rule-oflaw values in continuity, the federálist structure, and the rule of lenity (all of which were implicated in Oregon). These and other substantive canons constitute an interpretive regime, whose goal is not only to assert important constitutional or public values, but also to assert the Court's own important role to call a halt when agency elaboration and evolution of statutory purposes go too far. ${ }^{390}$

The same message ought to inform the Court's deference jurisprudence. The interpretive regime the Court has assembled, mostly through inadvertence, is a complicated continuum of deference tests that ought to be simplified and its key prongs (Chevron, Skidmore, and Oregon) clarified. Where Congress has delegated lawmaking authority to an expert agency and has left statutory criteria open-ended, the judicial role is at a minimum. Where an agency has applied its expertise to an issue as to which judges are substantively much less competent, judges should and do take a deferential attitude, subject to rule-of-law limits such as textual plain meanings, legislative compromises, and precedent. Where an agency interpretation raises larger normative concerns, including constitutional as well as larger statutory-purpose concerns, the judicial role is at its apex.

390. See Eskridge \& Frickey, supra note 255 , at 56 , for an early statement of this idea. 


\section{APPENDIX - CODEBOOK}

The dataset for this study consists of all Supreme Court cases decided after the 1983 Term decision in Chevron U.S.A., Inc. v. National Resources Deference Council and before the end of the 2005 term in which a federal agency interpretation of a statute was at issue. Each case was coded for 156 variables, described below.

The cases are listed in chronological order. The Burger Court cases are assigned numbers between 1 and 138. The Rehnquist Court cases are assigned numbers between 139 and 975 . The Roberts Court cases are assigned numbers between 976 and 1014 .

Variables

\section{Reporter}

Lists the Supreme Court Reporter citation for each case.

\section{Term}

Identifies the term in which the case was decided and the chronological order of cases within that term (e.g., the first relevant case for the 1985 term is 85.1 , the second is 85.2 , etc.).

\section{Name}

The case name consists of one to three words from the petitioner's name, unless the plaintiff is a common entity, such as the United States or the NLRA. In such cases, the case name consists of one to three words from the respondent's name. If both the petitioner and respondent have common names, the case name incorporates parts of both. Case names are included only to make case identification quicker and easier for database users.

\section{Chief Justice}

Burger $=0$

Rehnquist $=1$

Roberts $=2$

President

Reagan $=0$

Bush $\mathrm{I}=1$

Clinton $=2$

Bush II $=3$

Presidential Politics

Liberal $=0$ (Clinton)

Conservative $=1$ (Reagan, Bush I, Bush II)

\section{House}

Liberal $=0$ (Democrats control)

Conservative $=1$ (Republicans control) 


\section{Senate}

Liberal $=0$ (Democrats control)

Conservative $=1$ (Republicans control)

Note: Party control of the Senate shifted several times during the period we studied. The Republicans controlled the Senate until January 3, 1987. The Democrats controlled the Senate until January 3, 1995. The Republicans controlled the Senate between January 3, 1995 and May 24, 2001, when Senator Jeffords switched parties in an evenly divided Senate. The Democrats controlled the Senate between May 24, 2001 and January 3, 2003. The Republicans controlled the Senate for the remainder of the period covered by this study, January 3, 2003 through July 1, 2006.

\section{Agency}

\begin{tabular}{|l|l|l|}
\hline Treasury $=0$ & ICC $=16$ & FEC $=32$ \\
Copyright $=1$ & INS/DHS $=17$ & Nuclear Reg. Comm'n $=33$ \\
DOD/Armed Forces =2 & Interior $=18$ & FDA $=34$ \\
DOJ $=3$ & IRS $=19$ & CIA $=35$ \\
Education $=4$ & Labor $=20$ & CFTC $=36$ \\
EEOC $=5$ & NLRB $=21$ & Agriculture $=37$ \\
Energy $=6$ & OPM $=22$ & Commerce $=38$ \\
EPA $=7$ & Patent \& Trademarks $=23$ & HUD $=39$ \\
FDIC $=8$ & Pension Guar. $=24$ & Veterans Admin. $=40$ \\
Federal Reserve $=9$ & Post Office $=25$ & Customs $=41$ \\
FERC $=10$ & President/White House $=26$ & FAA $=42$ \\
FHLBB/FSLIC $=11$ & SEC $=27$ & Nat'l R.R. Adj. Board $=43$ \\
FLRA $=12$ & Sentencing $=28$ & Judicial Conference $=44$ \\
FTC $=13$ & Transportation $=29$ & Nat'l Mediation Bd. $=45$ \\
FCC $=14$ & Panama Canal Comm'n $=30$ & Comptroller General $=46$ \\
HHS $=15$ & Dep't of State $=31$ & \\
\hline
\end{tabular}

Note: For agencies within larger executive departments (such as the Coast Guard and the Army Corps of Engineers, both within the Department of Defense (DOD)), the department rather than the specific agency was coded, with the exception of the CIA, which has its own category. The residual category was the Department of Justice, whose Solicitor General represents the federal government before the Court in almost all cases and whose staff routinely make policy-significant decisions that the agencies themselves would not have made (and sometimes do not support). 


\section{Subject Matter}

\begin{tabular}{|l|l|l|}
\hline Bankruptcy $=1$ & Health \& Safety $=11$ & Education $=21$ \\
Business Regulation $=2$ & Immigration $=12$ & Foreign Affs/Nat'l Security = 22 \\
Civil Rights $=3$ & Indian Affairs $=13$ & Housing $=23$ \\
Criminal Law $=4$ & IP $=14$ & \\
Energy $=5$ & Labor Relations $=15$ & \\
Entitlement Programs =6 & Maritime $=16$ & \\
Environment $=7$ & Pensions $=17$ & \\
Federal Government $=8$ & Tax $=18$ & \\
Fed. Jur. \& Proc. $=9$ & Telecom $=19$ & \\
Federal Lands $=10$ & Transportation $=20$ & \\
\hline
\end{tabular}

\section{Agency Interpretation}

Liberal $=0$

Conservative $=1$

Neutral or Mixed $=2$

Note: Interpretations were coded as liberal if the agency view favored the interests of bankruptcy debtors, antitrust and securities plaintiffs, civil rights plaintiffs and other victims of discrimination (except claimants in "reverse discrimination" cases), criminal defendants, energy consumers, claimants seeking information or entitlement benefits from the government, citizens demanding environmental protection, plaintiffs seeking access to federal courts, governmental and private employees, persons benefiting from health/safety protections, immigrants, Native Americans, claimants opposing intellectual property interests, pension beneficiaries and state regulators of pension funds, taxpayers, telecomm and transportation consumers, students and their parents seeking educational benefits, and tenants.

Interpretations were coded as conservative if the agency view favored the interests of bankruptcy creditors, antitrust and securities defendants, alleged discriminators in civil rights cases (except defendants in "reverse discrimination" cases), criminal prosecutors, energy companies, agencies withholding information, government institutions paying for statutory entitlements, companies accused of polluting the environment, defendants opposing access to federal courts, governmental and private employers, defendants charged with violating health/safety rules, officials opposing the rights of immigrants, state and federal entities denying claims by Native Americans, holders of intellectual property interests, pension funds and their managers, tax collectors, telecomm 
and transportation companies, schools and school boards, and landlords. ${ }^{391}$

Interpretations were coded as neutral or mixed if the agency interpretation was liberal on one issue and conservative on another. See, for example, IBP, Inc. v. Alvarez, 546 U.S. 21 (2005) (presenting two issues to the Court, with Department of Labor regulation liberal on one issue, conservative on the other).

\author{
Agency Format \\ Legislative Rule or Executive Order $=.0$ \\ Formal Adjudication $=1$ \\ Informal Agency Interpretation $=2$ \\ Informal Interpretation \\ Agency Litigating Position $=1$ \\ Interpretative Rule/Guidance $=2$ \\ Agency Manual or Letter $=3$ \\ Agency/Solicitor General Amicus Brief $=4$ \\ Not Applicable $=999$
}

Continuity (Agency Position is ...)

Longstanding and Fairly Stable $=0$

Evolving $=1$

Recent $=2$

Note: An agency position was coded as longstanding and fairly stable if the agency had publicly and stably adhered to that same interpretation for a number of years before the Supreme Court took the case. The coding did not rely on a bright-line cut-off point, such as any interpretation that was ten years old counted as longstanding. The main reason is that the category is "longstanding and fairly stable," so time is not determinative without a judgment of stability. Also, it was often hard to tell exactly when the agency first took the position before the Court. Finally, the concept of "longstanding" is relative: a five-yearold child's practice of two years is longstanding, while something an eighty-yearold has been doing for a couple of years is not.

For recent statutes, therefore, a longstanding and fairly stable interpretation could be embodied in a formal declaration that was less than a decade old; if the agency had taken the same position since the early days of its enforcement of the statute, the position was coded as longstanding and fairly stable. Compare

391. The tax category could have been coded differently, as Michael Graetz pointed out to us. Is it conservative for a court to sustain the tax load of the well-to-do taxpayers and companies who bring most of the claims against the IRS? The coding choice to label pro-IRS rulings as conservative was driven by consistency with the other categories, which reflect the conventional view that progovernment rulings are conservative. The same normative ambiguity can be seen in criminal cases: it is not inevitably conservative for a court to sustain federal prosecutions against purveyors of fraud, auto thieves, sexual assaulters, etc., but that is the conventional, process-driven categorization in criminal law and procedure, and the coding scheme follows that idea in the tax cases. 
Bragdon v. Abbott, 524 U.S. 624 (1998), where the relevant agencies' interpretation of the ADA in 1990 had been formally adopted within a decade of the Supreme Court decision but reflected the only public interpretation those agencies had offered on the issue of AIDS coverage (and reflected the construction those agencies had placed on the Rehabilitation Act, upon which the ADA was based), with Spector v. Norwegian Cruise Line, Ltd., 545 U.S. 119 (2005), where the relevant agencies took no position on the ADA issue until 2004. Bragdon was coded as longstanding, Spector as recent.

For older statutes, an interpretation was not coded as longstanding and fairly stable unless the relevant agency had adhered to it, without wobbling, for a somewhat longer period of time. As before, the coding was attentive to whether the agency's position was consistent with its prior positions. For example, Texaco, Inc. v. Dagher, 547 U.S. 1 (2006) (interpreting the Sherman Act (1890)), was coded as longstanding, even though the DOJ/FTC Guidelines dated from 2000; the reason is that the Guidelines apparently reflected the agencies' stance well before that date. In contrast, Illinois Toolworks, Inc. v. Independent Ink, Inc., 547 U.S. 28 (2006) (also interpreting the Sherman Act), was coded as recent, even though the DOJ/FTC position was articulated in earlier 1995 Guidelines. The reason for the different treatment was that the DOJ/FTC Guideline in Toolworks was a renunciation of the position those agencies had taken in the prior generation (and was embedded in Supreme Court precedent the agencies were asking the Court to overrule in Toolworks) and so was not as stable as their interpretation in Dagher.

Evidence of a continuing agency interpretation was culled from the briefs in the case and from the Court's opinion. ${ }^{392}$ The agency position did not have to be reflected in a formal rule or adjudication but did have to have repeated (quasi)public expression over a period of time. In criminal cases, a pattern of lower court opinions accepting or rejecting the Department of Justice's interpretation over a period of five years or more was sufficient evidence of a longstanding and fairly stable interpretation on the part of DOJ (which of course rarely engages in national rulemaking to announce its interpretations of the criminal code). For example, see Cook County v. United States, 538 U.S. 119 (2003), where DOJ's interpretation of the False Claims Act had been developed and followed in a series of prosecutions over time, ultimately winning acceptance by the Court.

In regulatory cases, the best evidence of longstanding and fairly stable agency interpretation would be legislative rules left unchanged by the agency for a relatively long period of time. For example, see $K$ Mart Corp. v. Cartier, Inc., 486 U.S. 281 (1988), where the Customs Service had issued a series of

392. The methodology in text creates a bias in favor of longstanding and fairly stable interpretations because the Solicitor General's briefs almost always present the most detailed accounts of agency practice, and the Solicitor General has an incentive to present the agency's practice as longstanding and stable because that appeals to the Court's rule-of-law values. 
narrowing regulations in the 1930s-50s, therefore presenting an easy case of a longstanding and fairly stable interpretation by the time the Court heard the case (and struck down one of the regulations). Equally good evidence would be public adjudications taking the same position on a point of law over a lengthy period. If the agency adjudications wandered, however, then the agency position would be considered either evolving (if the wandering proceeded in a direction clearly indicating that the agency position was being driven by experience with a changing world) or recent.

Also, good evidence of longstanding and fairly stable agency views would be public rulings by the agency or opinions by its counsel (as in Bedroc Ltd. v. United States, 541 U.S. 176 (2004)); agency memoranda (as in Alaska Department of Environmental Conservation v. EPA, 540 U.S. 461 (2004)), especially if the memoranda were contemporaneous with the statute (as in National Archives \& Records Administration v. Favish, 541 U.S. 157 (2004)); agency compliance manuals and letters (as in Pennsylvania State Police $v$. Suders, 542 U.S. 129 (2004)); agency testimony before Congress or other public fora (as in FDA v. Brown \& Williamson Tobacco Corp., 529 U.S. 120 (2000)); and so on.

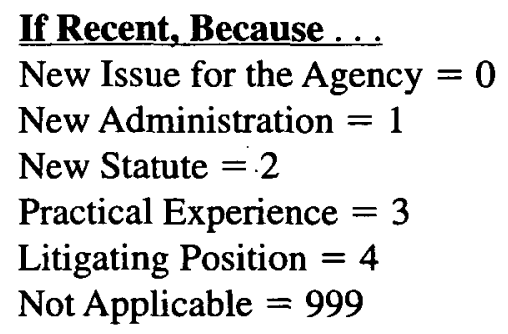

Note: An issue was coded as a new issue for the agency when the agency addressed the precise issue only recently, based on the evidence outlined in the previous Note. See, for example, Pennsylvania State Police v. Suders, 542 U.S. 129 (2004), where the Court followed a 2002 EEOC manual, and the case was coded as involving a recent interpretation because there was no evidence the EEOC had taken a position on the issue before 2002. Often agencies will take positions on new issues when the Supreme Court requests an amicus brief from the Solicitor General; often the whole point of the Court's request is probably to get the Solicitor General or the agency to think about an issue it has not taken a public position on, and so many of these cases will be coded as a new issue for the agency. This is especially true in bankruptcy cases, where there is no agency in charge of bankruptcy policy, but the Court frequently asks for Solicitor General briefs on Bankruptcy Act issues.

\section{Notice and Comment}

$$
\begin{aligned}
& \text { No }=0 \\
& \text { Yes }=1
\end{aligned}
$$


Note: Cases were coded "yes" for notice and comment if they involved an agency rule that had been issued after notice to and comment from interested persons, companies, and groups. Because most such rulemaking that is published in the Code of Federal Regulations involves notice and comment, cases involving legislative rules were coded as yes for notice and comment unless the briefs or the judicial opinion(s) indicated otherwise. For example, in Gonzales v. Oregon, 546 U.S. 243 (2006), both the Solicitor General's brief and the opinion for the Court emphasized that the Attorney General's Directive was not a rule issued pursuant to the notice-and-comment process.

\section{Acting Pursuant to Congressional Delegation of Lawmaking Authority$$
\text { No }=0
$$$$
\text { Yes }=1
$$

Note: To make this determination, the coder examined the underlying statutory authorization under which the agency was rendering the interpretation in suit. Agencies were coded as acting pursuant to congressional delegation of lawmaking authority if they were acting pursuant to a statutory authorization that met either the strict Merrill-Watts criterion (explained in the next Note) or the more lenient criterion developed by the federal courts in the 1970s, what we call the Petroleum Refiners criterion (explained in the Note after that). The Supreme Court's opinion in United States v. Mead Corp., 533 U.S. 218 (2001), includes all the cases that would be coded "yes" under Merrill-Watts and probably includes all or almost all of the cases that would be coded "yes" under Petroleum Refiners. Mead also theoretically includes some cases falling outside both categories, namely, those where there has been an "implicit" delegation of lawmaking authority, considering the broad context of the legislation. Mead did not supply sufficient guidance for this study to use in coding statutory delegations, and the lower courts have not been able to derive predictable standards either. Hence, cases are not coded for Mead's residual category, and delegated lawmaking authority under Mead might include some cases, but probably very few, if any, that are not so coded under this study's standards.

\section{Type of Delegation}

Delegation According to Strict (Merrill-Watts) Approach $=0$

Delegation According to Lenient (Petroleum Refiners) Approach $=1$

Not Applicable $=999$

Note: An agency rule or order was coded as falling under the strict approach if the statutory delegation met the rigorous standard set forth in Thomas Merrill \& Kathryn Tongue Watts, Agency Rules with the Force' of Law: The Original Convention, 116 HARv. L. Rev. 467 (2002). For statutes enacted before 1973, the Merrill-Watts standard requires that the statute vest an agency with the authority to issue rules or orders whose violation carries with it the possibility 
of immediate sanctions. For example, the NLRA (1935) does not satisfy this standard, because a party prevailing before the NLRB must still go to court to obtain an order requiring the losing party to comply. Other examples of early general statutory delegations that do not meet the strict approach include the Bank Holding Company Act of $1956 \S 5$ (b), 12 U.S.C. § 1844(b) (2000); Food Drug \& Cosmetic Act, 21 U.S.C. $\$ 346$ (2000); I.R.C. § 7805 (2000); Fair Labor Standards Act (FLSA), 29 U.S.C. $\S \S 201-209$. (2000); Title VII of the Civil Rights Act of 1964, 42 U.S.C. \$ 2000e (2000); Age Discrimination in Employment Act (ADEA) of $1967 \S 628,29$ U.S.C. $\S 628$ (2000); Title IX of the Education Amendments of 1972, 20 U.S.C. $\$ 1682$ (2000).

Statutory delegations that do meet the Merrill-Watts standard include the Federal Water Pollution Control Act (Clean Water Act) § 307, 33 U.S.C. § 1317 (2000) (concerning the EPA), and § 403, 33 U.S.C. $\S 1343$ (2000) (concerning the Army Corps of Engineers); Longshoremen and Harbor Workers' Compensation Act, 33 U.S.C. $\$ \S 901-50$ (2000) (delegating adjudication authority to the Office of Workers' Compensation Programs (OWCP) within the Department of Labor (DOL)); Securities and Exchange Act of $1933 \S 10(\mathrm{~b}), 15$ U.S.C. $\S 78 \mathrm{j}(\mathrm{b})$ (2000) (SEC); Federal Power Act, 16 U.S.C. $\S 824$ e (2000) (Federal Power Commission (FPC), now Federal Energy Regulatory Commission (FERC)); Sentencing Reform Act of 1984, 28 U.S.C. § 994 (2000). Statutory authorizations to the INS to detain, adjudicate, and deport noncitizens have the same lawmaking-delegation feature. Some agencies, such as IRS (under IRC) and DOL (under FLSA) do not have lawmaking authority under their general delegations, but their authorizing statutes have been amended to provide specific lawmaking authority (i.e., meeting Merrill-Watts) to address certain problems. See, for example, Auer v. Robbins, 519 U.S. 452 (1997) (DOL acting under special FLSA authorization, 29 U.S.C. § 213(a)(1) (2000)); Medtronic, Inc. v. Lohr, 518 U.S. 470 (1996) (FDA acting under special Medical Device Amendments of 1992, 21 U.S.C. § 360(k) (2000)).

Section 405(a) of the Social Security Act, 42 U.S.C. $\S 605$ (2000), is a slightly special case. Like the other delegations, $\S 409$ (a) does not give the SSA (now in HHS) the authority to make substantive law, and so it does not meet the Merrill-Watts standard for lawmaking delegation. See, for example, Sullivan v. Everhart, 494 U.S. 83 (1990). But § 405(a) does delegate to SSA the authority to make and enforce procedural rules, and some of the SSA cases involve that particular authority, which was coded as meeting Merrill-Watts. See, for example, Sullivan v. Zebley, 493 U.S. 521 (1990).

Merrill and Watts demonstrate that this standard had been forgotten by the 1970s and was obliterated by a series of court of appeals decisions announcing a more lenient standard. For statutes enacted in or after 1973 (a date Professor Merrill suggested to us), the Merrill-Watts standard would be satisfied by a statute vesting an agency with the authority to issue legislative (substantive) rules and engage in formal adjudications, the standard adopted in Petroleum Refiners. Thus, Congress enacted ERISA in 1974 and delegated general rulemak- 
ing authority to the Department of Labor and the IRS, 29 U.S.C. $\S 1135$. This delegation would not meet the Merrill-Watts test before 1973 but does meet it after that date. Another example is the Civil Service Reform Act (CSRA) of 1978, Pub. L. No. 95-454, 92 Stat. 1111 (codified as amended in scattered sections of 5 U.S.C.), which creates the Federal Labor Relations Authority and vests it with NRLB-like adjudication power. Before 1973, this would not meet Merrill-Watts; after 1973 it does.

The second category is a residual one, covering agency rules or orders that might be considered authorized lawmaking, but not according to the strict Merrill-Watts standard articulated above. Thus, an agency rule or order was coded as falling under the lenient approach if the statutory delegation did not meet the Merrill-Watts standard but did meet the more lenient approach of Petroleum Refiners, which suggested that congressional grants of power to issue legislative rules or engage in formal adjudications were lawmaking delegations. Thus, the NLRB's authorization to engage in formal adjudications would meet the Petroleum Refiners standard but not Merrill-Watts. For another example, IRC \& 7805 gives the IRS general rulemaking authority, but not power to impose sanctions (other IRC provisions do have immediate sanctions). Hence, this authority would not meet the Merrill-Watts standard and would fit into the residual category of Petroleum Refiners. In contrast, ERISA (1974) delegates legislative rulemaking authority to the IRS and the Department of Labor after Merrill-Watts pronounces that a more lenient standard has prevailed, and so ERISA cases involving IRS or DOL rules fall under Merrill-Watts and not Petroleum Refiners, as the coding system works for this study.

\section{Agency Issue 1: Jurisdiction and Regulatory Authority \\ Agency's Jurisdiction or Regulatory Authority NOT at Issue $=0$ \\ At Issue $=1$}

Note: An agency interpretation was coded as relating to the agency's jurisdiction or regulatory authority only if the agency was asserting (or denying) its own power to regulate a whole category of conduct or activity. Examples include Gonzales v. Oregon, 546 U.S. 243 (2006), where the Attorney General was asserting a new authority to criminalize a doctor's prescription of drugs in compliance with a state death-with-dignity law, and FDA v. Brown \& Williamson Tobacco Corp., 529 U.S. 120 (2000), where the FDA was asserting a new authority to regulate tobacco products. In National Cable \& Telecommunication Association v. Brand X Internet Services, 545 U.S. 967 (2005), the FCC opined that it did not have the authority to regulate cable companies providing broadband internet access pursuant to Title II of the Communications Act. Even though the agency was denying regulatory authority, the case was coded as relating to the agency's jurisdiction.

In contrast, if the agency were setting forth rules that regulated entities must follow or clarifying a regulatory category, the interpretation was coded as not 
involving the agency's jurisdiction or regulatory authority. Thus, in Bragdon $v$. Abbott, 524 U.S. 624 (1998), it was not disputed that Dr. Bragdon was subject to the ADA; he only argued that the ADA did not require him to treat a patient who was infected with HIV, the virus that leads to AIDS. Hence, this was not a case involving the agency's jurisdiction or regulatory authority.

\section{Agency Issue 2: Interpretation}

Agency Interpretation of Own Regulation NOT at Issue $=0$

At Issue $=1$

Note: Like some of the other variables in this Codebook, this one can only be figured in most cases by reading the briefs as well as the opinions in the case. The agency's brief, whether a party or an amicus brief, will usually identify the relevant rule(s). If the rule does not address the issue by its plain language, the brief typically represents the agency's interpretation of its own rule. (In order to avoid the fatal tag, "litigating position," the agency brief will identify any earlier written interpretations if they exist.)

\section{Agency Issue 3: Preemption}

Preemption of State Law NOT at Issue $=0$

At Issue $=1$

Agency Issue 4: National Security

Agency Interpretation Does NOT address Foreign Affairs or National Security Issue $=0$

At Issue $=1$

Note: Issues of foreign affairs or national security include immigration, international travel and trade, military affairs, and treaty interpretation. Issues having a transnational element were coded as foreign affairs or national security. Thus, the issue in Pasquantino v. United States, 544 U.S. 349 (2005), was whether the ADA applied extraterritorially; because this had potential international implications, the issue was coded as involving foreign affairs or national security.

\section{Decision Overall}

$$
\begin{aligned}
& \text { Liberal }=0 \\
& \text { Conservative }=1 \\
& \text { Neutral or Mixed }=2
\end{aligned}
$$

Note: Applies the same criteria for liberalism and conservatism as described above. Neutral decisions are those where there is no political valence for the issue decided. Mixed decisions are those where the Supreme Court ruled conservative on one issue and liberal on another issue, or split the political difference on one issue. 


\section{Decision with Respect to Agency}

Case Decided in Favor of Agency's Interpretation $=0$

Case Decided Against Agency's Interpretation $=1$

Mixed Decision $=2$

Note: Mixed decision captures situations in which the Supreme Court ruled for the agency with regard to some issues and against the agency with regard to others. For example, in South Florida Management District v. Miccosukee Tribe of Indians, 541 U.S. 95 (2004), the Court agreed with the agency suggestion that the case be remanded, but went against the agency on other issues raised in the case. Hence, this was coded as a mixed decision with respect to the agency's interpretation.

The Court did not have to accept the agency's interpretation $100 \%$ for the decision to be coded in favor of the agency's interpretation. In some cases, for example, the agency will offer a broader rationale or statement of the proper interpretation, but the Court accepts a narrower rationale or version. In those cases, the coding would still be in favor of the agency's interpretation.

\section{Outcome}

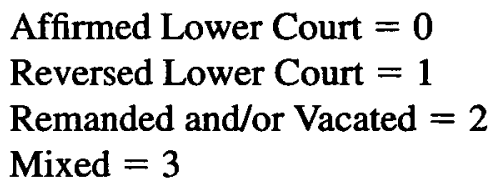

Note: The remanded and/or vacated category includes cases where the Supreme Court decided an issue of law but remanded the case back to the lower court to apply the rule to the case, to consider other legal issues, or to conduct other proceedings. See, for example, South Florida Management District v. Miccosukee Tribe of Indians, 541 U.S. 95 (2004). This category does not include cases where the Supreme Court just remands a case to a lower court for routine procedural action such as entry of a judgment consistent with the Court's opinion.

The mixed category includes cases where the Supreme Court affirmed in part and reversed in part.

\section{No $=0$ \\ Yes $=1$}

Unanimous

Note: Some cases included both statutory and constitutional issues; this study focused only on the statutory issues. Thus, a decision was coded as unanimous if there was no dissent from the disposition of the statutory issue, even if there was non-unanimity as to the constitutional issue(s). For example, the Court in Nevada Department of Human Resources v. Hibbs, 538 U.S. 721 (2003), was 
unanimous in concluding that the Family Medical Leave Act of 1993 applied to the states as employers (a contested issue on which certiorari was granted), but sharply divided as to the constitutionality of that application.

\section{Concurrences}

Number of concurring opinions written.

Note: As above, only concurrences as to statutory issues are noted. In Nevada Department of Human Resources v. Hibbs, 538 U.S. 721 (2003), there were concurring opinions as to the statutory issue (which are included in the coding), but not as to the constitutional issue.

\section{Dissents}

Number of dissenting opinions written

Note: As above, only dissents as to statutory issues are noted. For example, the Court in McConnell v. FEC, 540 U.S. 93 (2003), generally upheld the 2001 McCain-Feingold campaign finance law against First Amendment attack, but the majority narrowly construed $\S 323(\mathrm{~d})$, regulating donations. Justice Kennedy's opinion dissenting on the constitutional issues also tackled and disagreed on the statutory issue, but Justice Thomas's separate constitutional dissent ignored the statutory issue. Hence, only the Kennedy dissent was coded for purposes of this study.

\section{Chevron Cited}

$$
\begin{aligned}
& \text { No }=0 \\
& \text { Yes }=1
\end{aligned}
$$

Note: Decisions are coded as citing Chevron if the Court majority cited a precedent following and discussing Chevron and applying its two-step framework. For example, Chemical Manufacturers Ass'n. v. Natural Resources Defense Council, 470 U.S. 116 (1985); INS v. Cardozo-Fonseca, 480 U.S. 421 (1987); and K Mart Corp. v. Cartier, Inc., 486 U.S. 281 (1988), were early and leading cases that followed Chevron and applied its two-step formula. Some subsequent Supreme Court decisions cite only Chemical Manufacturers, CardozoFonseca, or $K$ Mart for the two-step Chevron test and so were coded as citing Chevron itself.

\section{Chevron Step Zero}

Does the Court think that the Chevron framework applies?

$$
\begin{aligned}
& \text { No }=0 \\
& \text { Yes }=1
\end{aligned}
$$

Note: Decisions are coded as applying the Chevron framework if the Court cited Chevron or a Chevron precedent (Chemical Manufacturers, Cardoza- 
Fonseca, or $K$ Mart) and then applied a deference approach consistent with Chevron.

Decisions are coded as not applying the Chevron framework when the Court cited Chevron or a Chevron precedent but announced that it need not decide whether Chevron applies, as the Court did in California Dental Ass'n v. FTC, 526 U.S. 756 (1999) (holding that the statute clearly supported the agency, so there was no need to determine whether Chevron governs). Obviously, this category also includes cases where the Court was not deferring, did not cite Chevron or a Chevron precedent, etc.

\section{Chevron Step One}

Does the Court determine that Congress has clearly addressed the issue?

No $=0$

Yes $=1$

Not Applicable $=999$

Note: Decisions are coded as yes, Congress has clearly addressed the issue, when the Court announces that there is an answer dictated by traditional sources of statutory meaning (statutory text, the whole act, legislative history and purpose, judicial precedent, various canons of statutory construction). It does not matter to the coding scheme whether Congress's answer is the same as, or different from, that of the agency.

Decisions are coded as no, Congress has not clearly addressed the issue, when the Court is unable to say for sure that there is one answer dictated by traditional sources of statutory meaning, as in Chevron itself. Thus, even when the Court believes that the traditional sources provide somewhat more support for one interpretation than another, but is not prepared to say that the other interpretation is precluded, the decision is coded as no, Congress has not clearly addressed the issue.

\section{Chevron Step Two}

Does the Court determine that the agency interpretation is reasonable?

$$
\begin{aligned}
& \text { No }=0 \\
& \text { Yes }=1 \\
& \text { Not Applicable }=999
\end{aligned}
$$

Note: Decisions are coded as yes, the Court determines that the agency interpretation is reasonable, when the Court applies Chevron (Step 0), announces that Congress has not clearly addressed the issue (Step 1), and says that the agency interpretation prevails. It is implicit in such decisions that the Court has made a judgment that the agency interpretation is "reasonable" for Chevron purposes. And, of course, if the Court explicitly says the agency interpretation is reasonable (Step 2), then the decision is coded as yes. 


\section{Reasons Cited for Reliance on Agency Interpretation}

Note: For each reason-category below, decisions are coded as no reliance on the reason if the Court says nothing explanatory and just cites and follows Chevron or another deference regime (such as Skidmore, Curtiss-Wright, and so forth).

\section{Agency Expertise}

$$
\begin{aligned}
& \text { No }=0 \\
& \text { Yes }=1
\end{aligned}
$$

\section{Accountability}

$$
\text { No }=0
$$$$
\text { Yes }=1
$$

\section{Longstanding.Agency Interpretation}

No $=0$

Yes $=1$

\section{Contemporaneous Agency Interpretation}

No $=0$

Yes $=1$

\section{Public Reliance}

No $=0$

Yes $=1$

Rulemaking Authority

No $=0$
Yes $=1$

Congressional Acquiescence

No $=0$

Yes $=1$

\section{Role of Chevron}

Not Cited $=0$

Cited but Not Applied $=1$

Cited and Applied $=2$

Note: See the Notes on Chevron Cited and Chevron Step Zero, above.

\section{Deference Regime Invoked}

No Regime Indicated, Directly or Indirectly $=0$

Anti-Deference (Lenity) $=1$

Consultative (Skidmore-Lite) Deference $=2$

Skidmore or Similar $=3$

Beth Israel et al. $=4$

Chevron $=5$

Seminole Rock $=6$

Curtiss-Wright $=7$ 
Note: "Deference regime invoked" captures the approach the Court takes towards agency deference. It does not measure whether the Court opinion was ultimately in favor of the agency interpretation, which is captured by the "decision with respect to agency" variable. Indeed, every deference regime includes both cases in which the agency interpretation is upheld and others in which it is rejected by the Court. There are eight possible deference regimes, listed below in reverse order (highest to lowest). Some Supreme Court decisions discuss and seem to apply more than one regime. In that event, the case was coded for the regime with the highest number. Thus, if the Court cited and seemed to apply Seminole Rock, Chevron, and Skidmore, as it did in Barnhart v. Walton, 535 U.S. 212 (2002), the case would be coded as Seminole Rock, the most deferential category.

7. Curtiss-Wright Super-Deference. A decision was coded Curtiss-Wright super-deference only if the Court announced that it was applying a special deference to executive department actions touching upon foreign affairs or national security. A decision was not coded Curtiss-Wright simply because it involved foreign affairs or national security issues. In most cases so coded, the Justices cited Curtiss-Wright or an analogous precedent, such as Mathews v. Diaz, 426 U.S. 67, 81 (1976) (broad statement of executive authority over immigration), but we also coded the decision Curtiss-Wright if the Court made clear it was applying special deference. Thus, in Department of Navy v. Egan, 484 U.S. 518, 530 (1988), the Court deferred to the agency on security clearances, saying that, "unless Congress specifically has provided otherwise, courts traditionally [should be] ... reluctant to intrude upon the authority of the Executive in military and national security affairs."

6. Seminole Rock Strong Deference. A decision was coded Seminole Rock only if the agency was interpreting one of its own regulations and the Court announced that it was following Seminole Rock or an analogous precedent, such as Auer v. Robbins, 519 U.S. 452 (1997), or Thomas Jefferson University v. Shalala, 512 U.S. 504 (1994). If the Court said nothing or announced the applicability of another deference regime, the coding will not invoke Seminole Rock. In Christensen v. Harris County, 529 U.S. 576 (2000), for example, the agency claimed to have been interpreting its own regulation, but the Court only applied Skidmore deference because the regulation was clear and did not require interpretation. Justice Scalia's dissenting opinion argued the applicability of Chevron and did not invoke Seminole Rock, probably for the reason given by the majority.

5. Chevron Deference. A decision was coded Chevron only if the Court cited Chevron or another Chevron case (Chemical Manufacturers, Cardozo-Fonseca, or $K$ Mart) and followed the Chevron framework of analysis. More than for the previous two categories, the agency did not prevail in many of the cases where the Court was applying Chevron deference. For example, Justice Scalia's plurality opinion in Rapanos v. United States, 126 S. Ct. 2208 (2006), applied Chevron deference and rejected the Corps of Engineers' interpretation because it was contrary to the plain meaning of the statute. 
Decisions were coded as Chevron when the Court applied Chevron, even if the coder thought the Court was wrong. For example, the Court in Presley $v$. Etowah County Commission, 502 U.S. 491 (1992), applied Chevron to a Department of Justice interpretation of the Voting Rights Act, even though the Act delegates no lawmaking authority to the Department, which is usually a litigant. This was, in our view, an incorrect deployment of Chevron, but the decision was coded as Chevron deference, as was Mead Corp. v. Tilley, 490 U.S. 714 (1989) (also an incorrect deployment of Chevron, in regard to a Department of Labor guidance and a letter).

4. Beth Israel Deference. Decisions were coded as Beth Israel deference if the Court applied a framework similar to Chevron (allowing any "reasonable" agency interpretation if Congress has not addressed the issue) but cited one of the pre-Chevron cases applicable to particular subject areas, including Beth Israel Hospital v. NLRB, 437 U.S. 483 (1978), and NLRB v. J. Weingarten, Inc., 420 U.S. 251 (1975), for NLRA cases; National Muffler Dealers Ass'n v. United States, 440 U.S. 472 (1979), for tax cases; Kolovrat v. Oregon, 366 U.S. 187 (1961), and Sumitomo Shoji of America, Inc. v. Avagliano, 457 U.S. 176 (1982), for treaty-interpretation cases.

For some areas judgment calls were made. The Court has not applied a consistent deference approach to the Guidelines developed and interpreted by the Sentencing Commission. In United States v. LaBonte, 520 U.S. 751 (1997), for example, the Court discussed Chevron deference but ultimately applied a more general deference, which was coded as Beth Israel-something beyond Skidmore but clearly not Chevron. In at least one sentencing case, the Court announced that it was applying Chevron deference, and the case was coded as Chevron.

3. Skidmore Deference. Decisions were coded as Skidmore deference if the Court announced that it would give deferential weight to agency views based upon considerations of expertise, continuity, and other Skidmore factors. Obviously, if the Court cited Skidmore and said it was applying its level of deference, the coding was easy. See, for example, Gonzales v. Oregon, 546 U.S. 243 (2006), and Christensen v. Harris County, 529 U.S. 576 (2000). Even when the Court failed to cite Skidmore, the decisions were coded as Skidmore (or higher) if the Court deployed the rhetoric of "deference." For example, in Ragsdale $v$. Wolverine World Wide, Inc., 535 U.S. 81 (2002), the Court gave a Department of Labor rule "substantial weight" in the interpretation of the FMLA; the decision was coded as Skidmore, even though the Court did not cite Skidmore.

In Smith v. City of Jackson, 544 U.S. 228, 238-39 (2005), the Court said it was deferring to the EEOC's ADEA Guidelines, without citing a particular deference regime. Because the Court has consistently used Skidmore and not Chevron for EEOC interpretations of Title VII and the ADEA, for example, in EEOC v. Aramco, 499 U.S. 244 (1991), and because the Smith decision emphasized Skidmore's functional factors, this decision was coded as Skidmore.

The Court in Lopez v. Monterey County, 525 U.S. 266 (1999), announced it 
was giving "substantial deference" to the Department of Justice's VRA interpretation. This decision might have been coded as Beth Israel, for the Court cited a pre-Chevron case (Sheffield), but the earlier case had emphasized the Skidmore factors of expertise and practical application. The Beth Israel category was reserved for pre-Chevron cases that emphasize Chevron-like delegations of lawmaking or gapfilling authority to agencies, not agency expertise and consistency.

In Meyer v. Holley, 537 U.S. 280 (2003), the Court mentioned both Chevron and Skidmore in deferring to a HUD interpretation. Normally, under the rule of the highest-numbered regime, the decision would have been coded as Chevron, but Justice Breyer's opinion for the Court only emphasized the functional Skidmore factors, and so the decision was coded as Skidmore. This was rare and may have been unique in this regard.

2. Consultative (Skidmore-Lite) Deference. This is a category that arose from the coder's perception that there were many cases where the Court's statutory interpretation was significantly influenced by agency-generated factual materials, interpretations, and recommendations - but where the rhetoric of "deference" or interpretive "weight" was substantially absent. Most of the decisions could have been coded as Skidmore (hence our nickname, Skidmore-Lite), because the agency inputs had functional value for the Court, and we would have no quarrel. The reason these cases are placed in a separate category is that the decisions were not written along lines of "deference," as Skidmore clearly is. Instead, the Court built on agency inputs to reach a decision, or used agency inputs to confirm the correctness of a decision. Hence, the separate category in this study.

There were several kinds of cases where this category was particularly apt. First are the decisions where the agency provides factual materials relevant to the statute as understood by the Court. An example is Hamdan v. Rumsfeld, 126 S. Ct. 2749 (2006). The Court not only rejected Justice Thomas's argument for applying Curtiss-Wright super-deference to the President's interpretation of the relevant treaties and military justice laws, but declined to invoke either Chevron or Skidmore deference in responding to the President's arguments. However, as to one issue the statute imposed a practicability requirement, and as to that the Court announced itself open to persuasion by the superior factual understanding the executive branch brought to that issue (though the Court ultimately disagreed with the President's bottom line). Id. at 2791. For that reason, Hamdan was coded as consultative deference. For another example, see Schaeffer $v$. Weast, 546 U.S. 49, 51, 59 (2006), where the Court relied on agency data on the enforcement of IDEA. Generally, a decision was not coded as consultative deference for this reason unless the Court explicitly acknowledged the value of the agency's factual inputs.

Second, cases were coded as consultative deference when the Court followed an agency amicus brief (usually solicited by the Court) propounding a distinctive resolution of the statutory issue before the Court. Thus, in Ministry of 
Defense and Support for the Armed Forces of the Islamic Republic of Iran $v$. Elahi, 546 U.S. 450 (2006), the Court acknowledged and closely followed the Department of State's amicus suggestions as to the proper (and safe) construction of the Foreign Sovereign Immunities Act (1976). In Texaco, Inc. v. Dagher, 126 S. Ct. 1276 (2006), the Court closely followed the Solicitor General's brief and the DOJ/FTC Antitrust Guidelines, but without explicit acknowledgment in the opinion for the Court. Nonetheless, the decision is coded consultative deference because the agency input significantly influenced the Court's interpretation. In Associates Commercial Corp. v. Rash, 520 U.S. 953 (1997), a bankruptcy case, the Court adopted the test proposed by the Solicitor General's amicus brief, and so that decision was coded as consultative deference. Cases are not coded as consultative deference when the United States was a party to the case, as in criminal matters, and the Court agreed with and followed its brief on the merits; in these cases, the agency is just another winning litigant. Consultative deference as a category in this study is reserved for those cases where the United States' participation is in a lawmaking or judge-like capacity, rather than as a litigant.

Third, cases were coded as consultative deference when the Court used an agency rule, policy, or interpretation as a premise or step in the Court's chain of reasoning (but without announcing at any point that the Justices were "deferring" or giving "weight" to the agency rule, etc.). For example, the Court in United States v. Sun-Diamond Growers of California, 526 U.S. 398 (1999), rejected the Independent Counsel's and DOJ's aggressive reading of the criminal law barring "unlawful gratuities." Although the Court had problems with the government's plain meaning arguments, the clinching argument for SunDiamond was that the government's broad reading undermined the regulations issued by the Office of Government Ethics. The regulations were part of the broad tapestry of law the Court was willing to consider. Likewise, in Illinois Tool Works Inc. v. Independent Ink, Inc., 547 U.S. 28 (2006), the Court counted revised DOJ/FTC Antitrust Guidelines as one reason it could overrule an old Sherman Act precedent that had been urged upon an earlier Court by the same agencies.

1. Anti-Deference. A decision was coded as anti-deference when the Court applied a presumption against the agency interpretation of the statute.

Most of the anti-deference cases were those where the Court invoked the rule of lenity (which construes ambiguous statutes in favor of criminal defendants). Most substantive criminal cases were not coded as anti-deference because the Court did not even mention the rule of lenity. Any mention of the rule of lenity triggered this coding, even if the mention were at the end of the opinion and even if the Court still accepted the Department of Justice's interpretation. A possible exception to this precept is Reno v. Koray, 515 U.S. 50 (1995), where the Court briefly discussed the rule of lenity as it might apply to a Bureau of Prisons interpretation relating to a defendant's conditions of confinement. Because the Court ultimately applied Skidmore deference to the Bureau's interpre- 
tation, the case was coded as Skidmore and not anti-deference.

Cases involving the constitutional avoidance canon (favoring interpretations that do not raise serious constitutional concerns) were coded as anti-deference if the Court anchored its opinion on the canon and it cut against the agency interpretation. For example, in Edward J. DeBartolo Corp. v. Florida Gulf Coast Building \& Construction Trades Council, 485 U.S. 568 (1988), the Court rejected an NLRB interpretation because it raised serious constitutional concerns. The case was coded as anti-deference because the Court's discussion started with the avoidance canon and concluded that there was no reason to determine Chevron's applicability because of the constitutional problem. The Court structured its opinion the same way in Solid Waste Agency v. Army Corps of Engineers, 531 U.S. 159 (2001), which rejected the Corp's construction of the Clean Water Act Amendments without reaching the Chevron issue, and so the case was coded as anti-deference. Contrast Rapanos v. United States, $126 \mathrm{~S}$. Ct. 2208 (2006), where the plurality opinion opened with Chevron's applicability and mentioned the avoidance canon as a reason supporting the plurality's plain meaning analysis; hence, Rapanos was coded as Chevron deference and was not coded as anti-deference.

We only included in this category those avoidance-canon cases in which the Court used the canon to create a presumption against the agency interpretation; we did not include cases that used the avoidance canon to rule in the agency's favor.

0 . No Deference. A decision was coded as no deference regime when the Court applied its traditional sources of statutory meaning, without citation to any deference regime and without any apparent reliance on the special facts or arguments advanced by the agency (in an amicus brief, etc.). The agency view might prevail under this regime, and the Court might in fact agree with the agency's argument(s), but unless the Court cited to the agency's position or its factual presentation or followed the unique argumentation of the agency's brief, the decision was coded as no deference regime.

\section{Interpretive Reasoning}

Every opinion in every case was coded according to the methods of statutory interpretation relied on by the Justices. The methods of statutory interpretation evaluated are outlined below.

Each method of interpretation was coded with the following rubric.

\begin{tabular}{|l|l|}
\hline 0 & No reference to this method of interpretation \\
\hline 1 & $\begin{array}{l}\text { Some reference to the method, but not } \\
\text { meaningfully relied on to advance reasoning }\end{array}$ \\
\hline 2 & $\begin{array}{l}\text { Genuine/positive reliance on method that } \\
\text { helps bring about the result reached }\end{array}$ \\
\hline
\end{tabular}




\begin{tabular}{|l|l|}
\hline 3 & $\begin{array}{l}\text { Method is "a" or "the" key determining } \\
\text { factor in the reasoning process }\end{array}$ \\
\hline 999 & $\begin{array}{l}\text { Indicates that ranking is not applicable } \\
\text { because no such opinion in case }\end{array}$ \\
\hline
\end{tabular}

Note that opinions are abbreviated as follows:

Majority $=\mathrm{M}$

Concurrence(s) $=\mathrm{C} 1, \mathrm{C} 2, \mathrm{C} 3$, etc.

$\operatorname{Dissent}(\mathrm{s})=\mathrm{D} 1, \mathrm{D} 2, \mathrm{D} 3$, etc.

Thus, in the dataset, "PlainM" is the column that lists reliance on plain meaning in the majority opinion $(0,1,2,3$, or 999), while "PlainCl" is the column that lists reliance on plain meaning in the first concurrence $(0,1,2,3$, or 999), and so on.

The methods of statutory interpretation that were evaluated are:

\section{Plain Meaning}

This method includes reliance on how an ordinary speaker would interpret the relevant statutory language, considering dictionaries, grammar, usage, and the linguistic canons such as inclusio unius. If an opinion discussed the text and found it ambiguous, it was coded as 1 ; if the opinion found a textual "plain meaning," it was coded as 2 or 3 depending on the reliance on this plain meaning in the opinion.

\section{Whole Act}

This method includes the whole-act canons, such as the rule against surplusage, the meaningful-variation maxim, etc. If an opinion discussed the whole act and found it ambiguous, it was coded as 1 ; if the opinion found that the whole act established or supported a "plain meaning," it was coded as 2 or 3 depending on the reliance on this reasoning in the opinion.

\section{Whole Code}

This method considers how other statutes shed light on the interpretation of the statute at issue. It includes the in pari materia rule, references to borrowed statutes, the presumption against implied repeals, etc. If an opinion discussed the whole code and found it ambiguous, it was coded as 1; if the opinion found that the whole code established or supported a "plain meaning," it was coded as 2 or 3 depending on the reliance on this reasoning in the opinion.

\section{Legislative History}

This method considers reliance on legislative history, such as committee reports and floor statements. It includes reliance on "subsequent legislative 
history," but not legislative inaction. If an opinion discussed the legislative history and found it irrelevant, unpersuasive, or insufficiently persuasive to counterbalance other factors, it was coded as 1 . If the opinion found that the legislative history confirmed the meaning suggested by the text or the whole act, it was coded as 2 . If the opinion found that the legislative history provided an independent basis for a statutory interpretation, it was coded as 3.

\section{Legislative Purpose}

This method considers reliance on references to what Congress meant to accomplish, the mischief aimed at being remedied, and general policy justifications imputed to a statute. (It also includes the purpose/policy behind a Constitutional provision when that is applicable.) If an opinion discussed the legislative purpose and found it irrelevant, unpersuasive, or insufficiently persuasive to counterbalance other factors, it was coded as 1 . If the opinion found that the legislative purpose confirmed the meaning suggested by the text or the whole act, it was coded as 2 . If the opinion found that the legislative purpose provided an independent basis for a statutory interpretation, it was coded as 3 .

\section{Stare Decisis}

This method includes reliance on the stare decisis doctrine and more general reliance on past decisions as authoritative or probative. If an opinion discussed precedent(s) and found it/them irrelevant, unpersuasive, or insufficiently persuasive to counterbalance other factors, it was coded as 1 . If the opinion found that precedent confirmed the meaning suggested by the text or the whole act, it was coded as 2 . If the opinion found that precedent provided an independent basis for a statutory interpretation, it was coded as 3 .

\section{Legislative Acquiescence}

This method includes reliance on evidence that the post-enactment Congress agreed with the agency view (for example, by ratifying the view when it reenacted or amended the statute, or by acquiescing in the agency view by leaving it intact after learning of it). If an opinion discussed legislative acquiescence and found it irrelevant, unpersuasive, or insufficiently persuasive to counterbalance other factors, it was coded as 1 . If the opinion found that legislative acquiescence confirmed the meaning suggested by the text or the whole act, it was coded as 2 . If the opinion found that legislative acquiescence provided an independent basis for a statutory interpretation, it was coded as 3 .

\section{Common Law}

This method includes reliance on common law meanings of terms used in statutes, as well as common law rules or baselines that are presumptively left 
in place or incorporated into statutes. If an opinion discussed the common law and found it irrelevant, unpersuasive, or insufficiently persuasive to counterbalance other factors, it was coded as 1 . If the opinion found that the common law confirmed the meaning suggested by the text or the whole act, it was coded as 2 . If the opinion found that the common law provided an independent basis for a statutory interpretation, it was coded as 3 .

\section{Federalism Canons}

This method includes the presumptions and clear-statement rules the Court has developed to protect federalism values, including the rules that judges ought not presume that Congress meant to preempt laws in which states are exercising their traditional police powers; that Congress must use specific language to abrogate state Eleventh Amendment immunity; etc. If an opinion discussed a federalism canon and found it irrelevant, unpersuasive, or insufficiently persuasive to counterbalance other factors, it was coded as 1 . If the opinion found that the canon confirmed the meaning suggested by the text or the whole act, it was coded as 2 . If the opinion found that the canon provided an independent basis for a statutory interpretation, it was coded as 3 .

\section{Avoidance Canon}

This method includes application of the rule that when a statute is susceptible of two readings, one of which raises "serious constitutional questions," judges should adopt the reading that "avoids" those questions. If an opinion discussed the avoidance canon and found it irrelevant, unpersuasive, or insufficiently persuasive to counterbalance other factors, it was coded as 1 . If the opinion found that the canon confirmed the meaning suggested by the text or the whole act, it was coded as 2 . If the opinion found that the canon provided an independent basis for a statutory interpretation, it was coded as 3.

\section{Due Process Canons}

The method encompasses the rule of lenity, the notion that ambiguous penal statutes should be construed in favor of defendants. If an opinion discussed the rule of lenity and found it irrelevant, unpersuasive, or insufficiently persuasive to counterbalance other factors, it was coded as 1 . If the opinion found that lenity confirmed the meaning suggested by the text or the whole act, it was coded as 2 . If the opinion found that lenity provided an independent basis for a statutory interpretation, it was coded as 3 .

\section{Other Substantive Canons}

This category absorbs residual substantive cannons, such as the rules presuming Congress not to invade the inherent powers of the other branches; not to apply regulations outside the territorial limits of the United States; to protect the rights of Native Americans; and so forth. If an opinion discussed a 
substantive canon and found it irrelevant, unpersuasive, or insufficiently persuasive to counterbalance other factors, it was coded as 1 . If the opinion found that the canon confirmed the meaning suggested by the text or the whole act, it was coded as 2 . If the opinion found that the canon provided an independent basis for a statutory interpretation, it was coded as 3 .

\section{Votes of Individual Justices (by Name)}

The vote of each justice is recorded with a three digit code. The first two digits indicate the opinion.

$10=$ Majority

$21=$ Concurrence 1

$22=$ Concurrence 2

$23=$ Concurrence 3

$31=$ Dissent 1 .

$32=$ Dissent 2

$33=$ Dissent 3

The third digit indicates whether the judge wrote the opinion (0) or joined it (1). So, for example, a judge who wrote the second concurrence would be coded as 220 . Judges are only coded for one opinion. If a judge wrote an opinion, s/he is automatically coded for that opinion. If a judge wrote or joined a concurrence, $s / h e$ is coded for the concurrence, even if $s / h e$ also joined the majority.

$0=$ Not on Court

$400=$ Did Not Participate in Decision

Authorship of Opinions for Majority, Concurrence(s) and Dissent(s)

Not Applicable Because No Such Opinion in Case $=999$

Brennan $=1$

White $=2$

Marshall $=3$

Burger $=4$

Blackmun $=5$

Powell $=6$

Rehnquist $=7$

Stevens $=8$

O'Connor $=9$

Scalia $=10$

Kennedy $=11$

Souter $=12$

Thomas $=13$

Ginsburg $=14$ 
[Vol. 96:1083

Breyer $=15$

Roberts $=16$

Alito $=17$

Per Curiam $=18$

Joint $=19$ 